Portland State University

PDXScholar

1996

\title{
A Semiquantitative Analysis of PCB and P,P-DDE Residues in Stranded Marine Mammals Using High Performance Liquid Chromatography
}

David Lawrence Hayteas

Portland State University

Follow this and additional works at: https://pdxscholar.library.pdx.edu/open_access_etds Let us know how access to this document benefits you.

\section{Recommended Citation}

Hayteas, David Lawrence, "A Semiquantitative Analysis of PCB and P,P-DDE Residues in Stranded Marine Mammals Using High Performance Liquid Chromatography" (1996). Dissertations and Theses. Paper 1395.

https://doi.org/10.15760/etd.1394

This Dissertation is brought to you for free and open access. It has been accepted for inclusion in Dissertations and Theses by an authorized administrator of PDXScholar. Please contact us if we can make this document more accessible: pdxscholar@pdx.edu. 
A SEMIQUANTITATIVE ANALYSIS OF PCB AND P,P-DDE RESIDUES IN STRANDED MARINE MAMMALS USING HIGH PERFORMANCE LIQUID CHROMATOGRAPHY

\author{
by \\ DAVID LAWRENCE HAYTEAS
}

A dissertation submitted in partial fulfillment of the requirements for the degree of

DOCTOROF PHILOSOPHY

in

ENVIRONMENTAL SCIENCES AND RESOURCES:

BIOLOGY

Portland State University

1996 
UMI Number: 9635652

UMI Microform 9635652

Copyright 1996, by UMI Company. All rights reserved.

This microform edition is protected against unauthorized copying under Title 17, United States Code.

\section{UMI \\ 300 North Zeeb Road \\ Ann Arbor, MI 48103}




\section{DISSERTATION APPROVAL}

The abstract and dissertation of David Lawrence Hayteas for the Doctor of Philosophy in Environmental Sciences and Resources: Biology were presented June 12, 1996, and accepted by the dissertation committee and the doctoral program.

COMMITTEE APPROVALS:
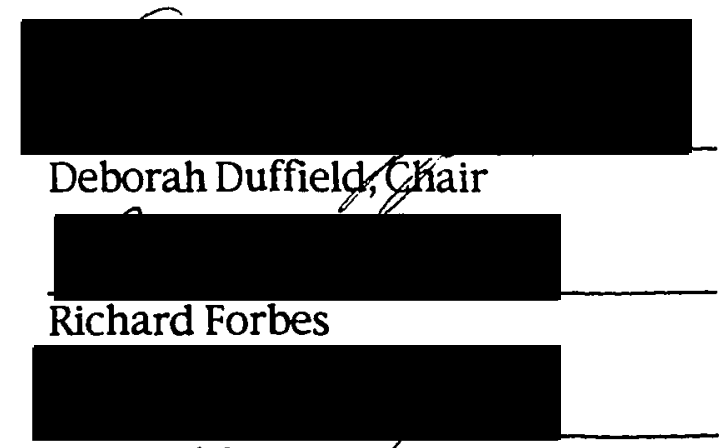

$$
\text { Leonard Simpson }
$$

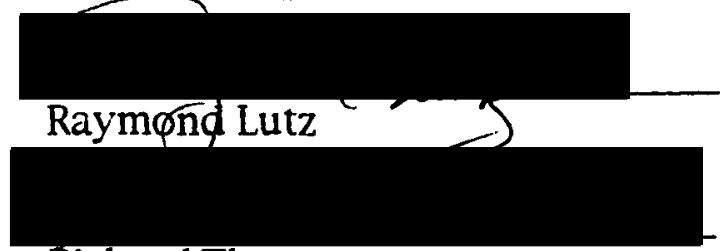

Richard Thoms

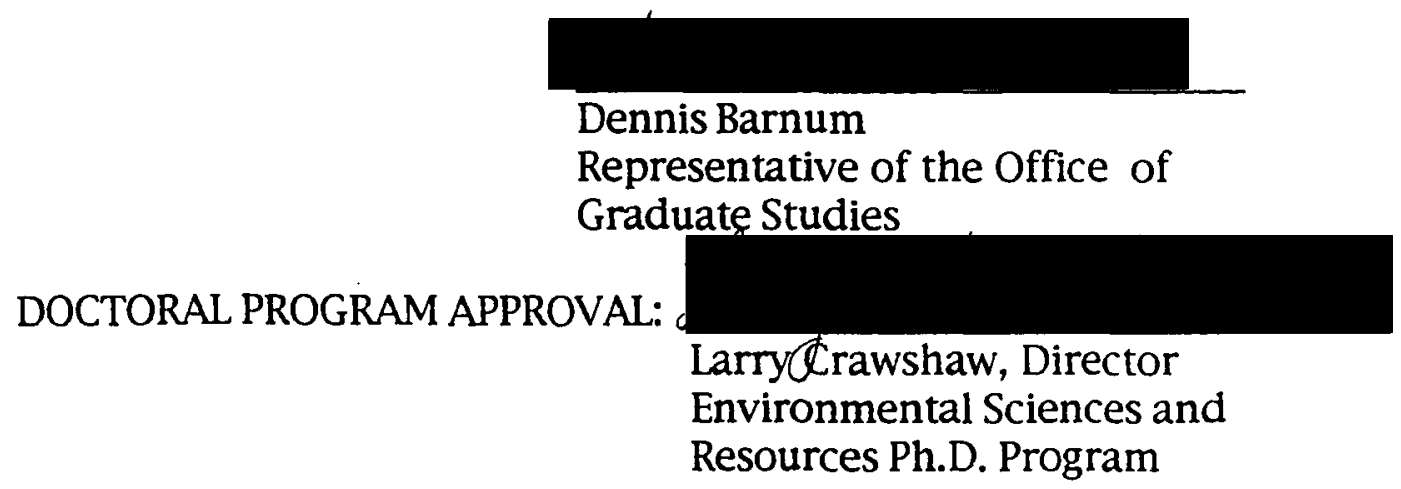

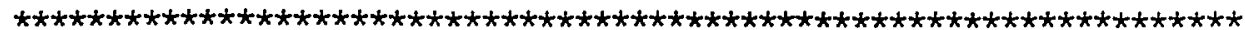

ACCEPTED FOR PORTLAND STATE UNIVERSITY BY THE LIBRARY by on 3 a fenter licie 
ABSTRACT

An abstract of the dissertation of David Lawrence Hayteas for the Doctor of Philosophy in Environmental Sciences and Resources: Biology presented June 12, 1996.

Title: A Semiquantitative Analysis of PCB and P,P-DDE Residues in Stranded Marine Mammals Using High Performance Liquid Chromatography

Organochlorines are ubiquitous pollutants of the marine environment. These lipid-soluble and highly persistent compounds are found in detectable amounts in almost all marine organisms, and accumulate in the lipid tissues of marine animals. This bioaccumulation leads to biomagnification of these contaminants in higher trophic levels. Near the top of many marine food chains are found the marine mammals, in whose blubber high levels of organochlorine residues have been measured. The most commonly occurring of these pollutants in these animals are the polychlorinated biphenyls (PCB's) and p,pDDE, a metabolite of the insecticide DDT. These substances have been shown to cause disruptions in the endocrine, immune, and reproductive systems, and are passed from mother to offspring through the placenta and by lactation. Presence and levels of residues of these compounds are, therefore, monitored in marine 
mammals to provide an indication of the health of a given population and the environment in which they live.

Such monitoring is generally done with the use of gas chromatography (GC). High performance liquid chromatography (HPLC) is little used due to the poor ultraviolet (UV) absorbance properties of many of the organochlorines. PCB's and p,p-DDE do absorb UV well enough at concentrations usually encountered in marine mammals to permit the use of HPLC for detection and semiquantification of these substances. A method was developed for the screening of blubber of marine mammals for total PCB's and $p, p-D D E$ using HPLC. The method was applied to the detection and approximation of levels of these two organochlorines in marine mammals from the east and west coasts of the United States. Geographical differences in levels of the two pollutants were found, indicating differences in primary feeding ranges. Evidence of placental transfer of these two organochlorines was also found. Especially high residue levels were found in the blubber of stranded killer whales, indicating that acquisition of high pollutant burdens is still a problem in these top predators. It was concluded that HPLC can be used to screen marine mammals for PCB's and p,p-DDE, and that residue levels determined can be useful in investigating species range, pollutant burdens, and health of populations. 
ACKNOWLEDGEMENTS

First of all, I want to thank Dr. Deborah Duffield, my advisor and friend, for all her help and encouragement. Throughout this entire project she provided the advice and resources which enabled it to be completed. It is no exaggeration to state that the pages which follow would have been impossible without her.

Secondly, I would also like to thank Dr. Richard Forbes for so carefully reading and commenting on the draft of this document, and for his counsel during the course of this work. Thanks are also extended to the other members of my dissertation committee, Dr. Leonard Simpson, Dr. Raymond Lutz, Dr. Richard Thoms, and Dr. Dennis Barnum, who all reviewed my dissertation draft, and made helpful comments during the defense. My fellow graduate students, Leslie Parr and Richard Rausch, provided support and sympathy throughout these last five years, as did my good friend, Lynn Larson, who also provided immeasurable assistance in securing supplies and employment.

Thirdly, I want to dedicate this dissertation to my wife, Victoria, who was at my side during the entire time it took for this project to be finished. She never doubted that it would be a success; I could never have done it without her.

Finally, I wish to remember my dog, Skoshi, a constant companion during most of this doctoral project, but who, sadly, did not live to see the final product. 
TABLE OF CONTENTS

ACKNOWLEDGEMENTS.........................II

LIST OF TABLES $\ldots \ldots \ldots \ldots \ldots \ldots \ldots \ldots \ldots \ldots \ldots \ldots$

LIST OF FIGURES $\ldots \ldots \ldots \ldots \ldots \ldots \ldots \ldots \ldots \ldots \ldots$ VIII

\section{CHAPTER}

I INTRODUCTION.........................

I I PEVIEW OF RECENT LITERATURE . . . . . . . . . . . 5

III THE USE OF HPLC FOR THE ESTIMATION OF PCB AND DDE RESIDUES IN MARINE MAMMALS. . . .76

Introduction. .....................76

Experimental....................78

Results........................84

Discussion.......................90

IV THE SEMIQUANTITATIVE DETERMINATION

OF PCB'S AND DDE IN STRANDED MARINE

MAMMALS USING HPLC . . . . . . . . . . . . . .95

Introduction.....................95

Materials and Methods. ..............97

Results.........................98

Discussion......................113

V CONCLUSIONS.......................123 
APPENDICES

A CLASSIFICATION OF RECENT

MARINE MAMMALS. . . . . . . . . . . . . 125

B STEPWISE EXPERIMENTAL PROTOCOL. . . . . . . . 131

C HPLC AND TLC CHROMATOGRAMS ...........141

BIBLIOGRAPHY. . . . . . . . . . . . . . . . . . . . . 198 


\section{LIST OF TABLES}

\section{TABLE}

I Total DDT (DDT+DDE+DDD) in Lake Michigan.......28

I I DDE in a Marine Ecosystem .............28

II Organochlorine Concentrations (ppm - wet wt.)

Reported in the Blubber of the Harbor Seal

(Phoca vitulina)..................53

IV Organochlorine Concentrations (ppm - wet wt.)

Reported in the Blubber of the Ringed Seal

(Phoca hispida) .......................

V Organochlorine Concentrations (ppm - wet wt.)

Reported in the Blubber of the Grey Seal

(Halichoerus grypus) . . . . . . . . . . . 58

V I Organochlorine Concentrations (ppm - wet wt.)

Reported in the Blubber of Other Seals. . . . . .60

VII Organochlorine Concentrations (ppm - wet wt.)

Reported in the Blubber of the California

Sea Lion (Zalophus californianus) . . . . . . . . .62

VIII Organochlorine Concentrations (ppm - wet wt.)

Reported in the Blubber of the Killer Whale

(Orcinus orca) . . . . . . . . . . . . . . .63

IX Organochlorine Concentrations (ppm - wet wt.)

Reported in the Blubber of the Bottlenose

Dolphin (Tursiops truncatus) . . . . . . . . . 64 
X Organochlorine Concentrations (ppm - wet wt.)

Reported in the Blubber of the Common

Dolphin (Delphinus delphis) .............65

XI Organochlorine Concentrations (ppm - wet wt.)

Reported in the Blubber of the Striped

Dolphin (Stenella coeruleoalba) ..........66

XII Organochlorine Concentrations (ppm - wet wt.)

Reported in the Blubber of the Beluga

(Delphinapterus leucas) ..............67

XIII Organochlorine Concentrations (ppm - wet wt.)

Reported in the Blubber of the Harbor

Porpoise (Phocoena phocoena) ...........68

XIV Organochlorines Concentrations (ppm - wet wt.)

Reported in the Blubber of

Other Odontocetes....................70

XV Organochlorine Concentrations (ppm - wet wt.)

Reported in the Blubber of Mysticetes . . . . . .75

XVI Concentrations (ppm - wet wt.) of Total PCB's

and $p, p-D D E$ Found in the Blubber of the

Harbor Seal (Phoca vitulina) ............106

XVII Concentrations (ppm - wet wt.) of Total PCB's

and $p, p-D D E$ Found in the Blubber of

Other Pinnipeds...................107 
XVIII Concentrations (ppm - wet wt.) of Total PCB's and p,p-DDE Found in the Blubber of the Harbor Porpoise (Phocoena phocoena). . . . .108

XIX Concentrations (ppm - wet wt.) of Total PCB's and $p, p-D D E$ Found in the Blubber of Other Cetaceans and Carnivores ...........109

XX Concentrations (ppm - wet wt.) of Total PCB's and p,p-DDE Found in the Blubber of the Killer Whale (Orcinus orca) ............112 
VIII

\section{LIST OF FIGURES}

\section{FIGURE}

1. Examples of PCB's $\ldots \ldots \ldots \ldots \ldots \ldots \ldots \ldots$

2. $\quad \mathrm{p}, \mathrm{p}-\mathrm{DDT} \ldots \ldots \ldots \ldots \ldots \ldots \ldots \ldots \ldots \ldots \ldots \ldots$

3. Some DDT analogues $\ldots \ldots \ldots \ldots \ldots \ldots \ldots \ldots$

4. Lindane, toxaphene, and some cyclodienes. .......10

5. Metabolites of $\mathrm{p}, \mathrm{p}-\mathrm{DDT} \ldots \ldots \ldots \ldots \ldots \ldots \ldots \ldots \ldots \ldots$

6. HPLC chromatograms of p,p-DDE @ 100 ug/g and Aroclor $1254 @ 100$ ug/g............85

7. HPLC chromatograms of oxidized p,p-DDE @ $10 \mathrm{ug} / \mathrm{g}$ and p,p-DCBP @ $10 \mathrm{ug} / \mathrm{g} . . . . . .886$

8. HPLC chromatogram of oxidized Aroclor 1260

@ $100 \mathrm{ug} / \mathrm{g}$ and p,p-DDE @ $50 \mathrm{ug} / \mathrm{g} . . . . . .87$

9. HPLC chromatograms of harbor seal (Phoca vitulina) and California sea lion (Zalophus californianus). .88

10. HPLC chromatograms of pilot whale

(Globicephala macrorhynchus) and Commerson's dolphin (Cephalorhynchus commersonii). . . . . . . . . . . . . . . . . . . .89

11. HPLC chromatograms of p,p-DDE@ 10 ug/g and Aroclor 1254@100 ug/g.............101

12. HPLC chromatograms of oxidized p,p-DDE @ $10 \mathrm{ug} / \mathrm{g}$ and p,p-DCBP@ $10 \mathrm{ug} / \mathrm{g} . . . \ldots \ldots .102$ 
13. HPLC chromatograms of the cleaned extract of California sea lion (Zalophus californianus) before oxidation and after oxidation.....................103

14. HPLC chromatogram of the oxidized extract of harbor seal (phoca vitulina)...........104

15. HPLC chromatogram of the oxidized extract of harbor porpoise (Phocoena phocoena) . . . 104

16. HPLC chromatogram of the oxidized extract of killer whale (Orcinus orca) ...........105 Figures 17 - 92 are HPLC chromatograms unless otherwise noted.

17. Hexane only $\ldots \ldots \ldots \ldots \ldots \ldots \ldots \ldots \ldots \ldots \ldots \ldots \ldots$

18. Aroclor 1254 standard @ $100 \mathrm{ug} / \mathrm{ml} . . . . . . . . .141$

19. Aroclor 1254 standard @ $1000 \mathrm{ug} / \mathrm{ml} . . . . . . . . .142$

20. Aroclor standards @ $100 \mathrm{ug} / \mathrm{ml}$ :

Aroclor 1248 and Aroclor 1260 ..........143

21. p,p-DDE standards: $100 \mathrm{ug} / \mathrm{ml}$ and $10 \mathrm{ug} / \mathrm{ml}$.....144

22. p,p-DCBP standard @ $100 \mathrm{ug} / \mathrm{ml} . \ldots \ldots \ldots \ldots \ldots 145$

23. Oxidized p,p-DDE standard @ $100 \mathrm{ug} / \mathrm{ml} . . . \ldots . .146$

24. Oxidized standards: p,p-DCBP@ $10 \mathrm{ug} / \mathrm{ml}$ and p,p-DDE @ $10 \mathrm{ug} / \mathrm{ml}$................147

25. Oxidized Aroclor 1254 standard @ $100 \mathrm{ug} / \mathrm{ml} . . .148$

26. Oxidized solution of Aroclor 1260 standard @ $100 \mathrm{ug} / \mathrm{ml}$ and p,p-DDE @ $45 \mathrm{ug} / \mathrm{ml} . . . . . .148$ 
27. Cleaned and oxidized extract from organically raised cattle..............149

28. NIST/NOAA whale blubber sample SRM $1945 \ldots 149$

29. Cleaned and oxidized extract of sample from organically raised cattle spiked with $1 \mathrm{ml}$ of Aroclor 1260 standard @ 100 ug/ml .....150

30. Cleaned and oxidized extract of sample from organically raised cattle spiked with $1 \mathrm{ml}$ of p,p-DDE standard @ $45 \mathrm{ug} / \mathrm{ml}$...........150

31. Cleaned and oxidized extract of sample of the beaked whale spiked with $1 \mathrm{ml}$ of Aroclor $1254 @ 100 \mathrm{ug} / \mathrm{ml}$ and $1 \mathrm{ml}$ of p,p-DDE @ $45 \mathrm{ug} / \mathrm{ml}$. 151

32. Cleaned and oxidized extract of sample of the striped dolphin spiked with $1 \mathrm{ml}$ of Aroclor $1254 @ 100 \mathrm{ug} / \mathrm{ml}$ and $1 \mathrm{ml}$ of p,p-DDE@ $45 \mathrm{ug} / \mathrm{ml}$. 152

33. Cleaned and oxidized extract of sample of the harbor porpoise $(1 / 13 / 96)$ spiked with $1 \mathrm{ml}$ of Aroclor $1254 @ 100 \mathrm{ug} / \mathrm{ml}$ and $1 \mathrm{ml}$ of $\mathrm{p}, \mathrm{p}$-DDE @ $50 \mathrm{ug} / \mathrm{ml}$.

34. Cleaned and oxidized extract of sample of the harbor seal (10/10/95) spiked with $1 \mathrm{ml}$ of Aroclor $1254 @ 100 \mathrm{ug} / \mathrm{ml}$ and $1 \mathrm{ml}$ of $\mathrm{p}, \mathrm{p}-\mathrm{DDE} @ 45 \mathrm{ug} / \mathrm{ml} . . . \ldots \ldots \ldots . . . . .154$ 
35. TLC confirmatory chromatograms of standards

@ $100 \mathrm{ug} / \mathrm{ml}$ : Aroclor 1248, Aroclor 1254, Aroclor 1260, p,p-DDE, p,p-DCBP, oxidized $p, p-D D E \ldots \ldots \ldots \ldots \ldots \ldots \ldots \ldots \ldots$

36. TLC confirmatory chromatograms of cleaned and oxidized extracts of samples of the Steller's sea lion (4/4/91), harbor porpoise (4/15/95), common dolphin (5/6/93), and striped dolphin $(4 / 15 / 95) \ldots \ldots \ldots \ldots \ldots \ldots . . .156$

37. TLC confirmatory chromatograms of cleaned and oxidized extracts of samples of the false killer whale (10/8/93), Commerson's dolphin (1983), killer whale (7/24/93), and killer whale $(5 / 13 / 95) \ldots \ldots \ldots \ldots \ldots \ldots \ldots . . .157$

38. Harbor seal (Phoca vitulina) $-(5 / 10 / 91) \ldots . \ldots .158$

39. Harbor seal (Phoca vitulina) $-(2 / 24 / 92) \ldots \ldots \ldots 158$

40. Harbor seal (Phoca vitulina) $-(10 / 10 / 95)$.......159

41. Harbor seal (Phoca vitulina) - (3/1/91) .........159

42. Harbor seal (Phoca vitulina) $-(2 / 23 / 92) \ldots . . .160$

43. Harbor seal ( Phoca vitulina) $-(2 / 24 / 92) \ldots \ldots \ldots 160$

44. Harbor seal (Phoca vitulina) $-(4 / 10 / 95) \ldots . . .161$

45. Harbor seal (Phoca vitulina) $-(8 / 11 / 95) \ldots . . .161$

46. Harbor seal (Phoca vitulina) - (4/18/95) ........162

47. Harbor seal (Phoca vitulina) $-(7 / 15 / 95)$........162

48. California sea lion (Zalophus californianus) - 
49. California sea lion (Zalophus californianus) -

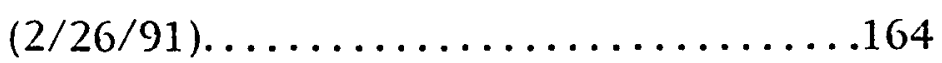

50. California sea lion (Zalophus californianus) -

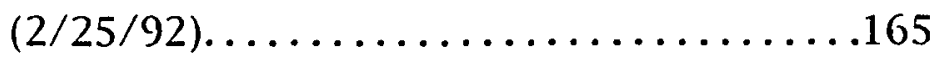

51. California sea lion (Zalophus californianus) -

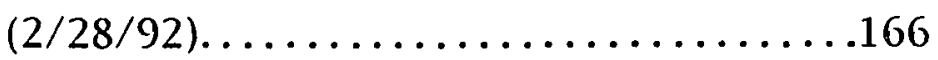

52. California sea lion (Zalophus californianus) (12/6/95)........................

53. California sea lion (Zalophus californianus) $(2 / 25 / 92$, juvenile) .................168

54. Steller's sea lion (Eumetopias jubatus) (4/4/91).......................

55. Steller's sea lion (Eumetopias jubatus) -

(4/15/91)......................170

56. Northern elephant seal (Mirounga angustirostris) $-(7 / 5 / 95) \ldots \ldots \ldots \ldots \ldots 170$

57. Harbor porpoise (Phocoena phocoena) -

(4/15/95).......................171

58. Harbor porpoise (Phocoena phocoena) -

$(6 / 21 / 95) \ldots \ldots \ldots \ldots \ldots \ldots \ldots \ldots \ldots 171$

59. Harbor porpoise (Phocoena phocoena) -

$(10 / 27 / 95) \ldots \ldots \ldots \ldots \ldots \ldots \ldots \ldots . . . \ldots \ldots 2$

60. Harbor porpoise (Phocoena phocoena) -

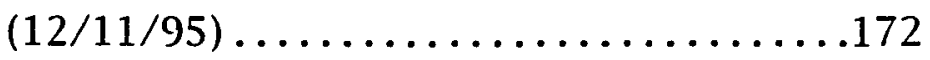

61. Harbor porpoise (Phocoena phocoena) -

$(9 / 29 / 92) \ldots \ldots \ldots \ldots \ldots \ldots \ldots \ldots \ldots . \ldots \ldots+\ldots \ldots$ 
62. Harbor porpoise (Phocoena phocoena) -

$(5 / 6 / 93) \ldots \ldots \ldots \ldots \ldots \ldots \ldots \ldots \ldots \ldots \ldots \ldots+174$

63. Harbor porpoise (Phocoena phocoena) -

(4/11/94)..................... 175

64. Harbor porpoise (Phocoena phocoena) -

$(4 / 15 / 95) \ldots \ldots \ldots \ldots \ldots \ldots \ldots \ldots \ldots \ldots \ldots$

65. Harbor porpoise (Phocoena phocoena) -

$(1 / 13 / 96) \ldots \ldots \ldots \ldots \ldots \ldots \ldots \ldots \ldots \ldots \ldots$

66. Harbor porpoise (Phocoena phocoena) -

$(7 / 1 / 92) \ldots \ldots \ldots \ldots \ldots \ldots \ldots \ldots \ldots \ldots \ldots$

67. Harbor porpoise (Phocoena phocoena) -

$(7 / 23 / 95) \ldots \ldots \ldots \ldots \ldots \ldots \ldots \ldots \ldots \ldots \ldots \ldots$

68. Harbor porpoise (Phocoena phocoena) -

$(7 / 11 / 95) \ldots \ldots \ldots \ldots \ldots \ldots \ldots \ldots \ldots \ldots \ldots \ldots$

69. Common dolphin (Delphinus delphis) - (5/6/93) . .179

70. Common dolphin (Delphinus delphis) - (1994) . . . 180

71. Common dolphin (Delphinus delphis) - (1/13/96) .181

72. Striped dolphin (Stenella coeruleoalba) -

$(4 / 15 / 95) \ldots \ldots \ldots \ldots \ldots \ldots \ldots \ldots . .182$

73. Bottlenose dolphin (Tursiops truncatus) -

$(2 / 25 / 93) \ldots \ldots \ldots \ldots \ldots \ldots \ldots \ldots \ldots \ldots \ldots . .183$

74. Dall's porpoise (Phocoenoides dalli) - (4/10/95) . . 183

75. Risso's dolphin (Grampus griseus) - (10/5/95) . . .184

76. False killer whale (Pseudorca crassidens) -

$(10 / 8 / 93) \ldots \ldots \ldots \ldots \ldots \ldots \ldots \ldots \ldots . . .185$ 
77. Stejneger's beaked whale (Mesoplodon stejnegeri) $-(10 / 95) \ldots \ldots \ldots \ldots \ldots \ldots \ldots 186$

78. Minke whale (Balaenoptera acutorostrata) -

$(5 / 25 / 93) \ldots \ldots \ldots \ldots \ldots \ldots \ldots \ldots \ldots . .186$

79. Walrus (Odobenus rosmarus) - (12/20/95). .....187

80. Polar bear (Ursus maritimus) $-(10 / 18 / 95) \ldots \ldots .187$

81. Bottlenose dolphin (Tursiops truncatus) -

$(7 / 7 / 91) \ldots \ldots \ldots \ldots \ldots \ldots \ldots \ldots \ldots . \ldots \ldots$

82. Bottlenose dolphin (Tursiops truncatus) -

(5/3/92) ....................... 189

83. Bottlenose dolphin (Tursiops truncatus) - (1993). .189

84. Short-finned pilot whale (Globicephala macrórhynchus $)-(12 / 22 / 88) \ldots \ldots \ldots \ldots . .190$

85. Short-finned pilot whale (Globicephala macrorhynchus) - (1993)..............191

86. Commerson's dolphin (Cephalorhynchus commersonii) $-(1983) \ldots \ldots \ldots \ldots \ldots \ldots 192$

87. Commerson's dolphin (Cephalorhynchus commersonii) $-(5 / 7 / 91) \ldots \ldots \ldots \ldots \ldots 193$

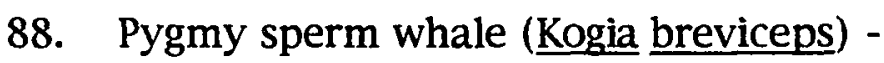
(4/20/92).......................193

89. Pygmy sperm whale (Kogia breviceps) (8/31/92)......................

90. Killer whale (

91. Killer whale (Orcinus orca) $-(7 / 24 / 93) \ldots \ldots \ldots .196$

92. Killer whale (Orcinus orca) $-(5 / 13 / 95) \ldots \ldots \ldots . .197$ 


\section{CHAPTER I}

\section{INTRODUCTION}

The oceans cover approximately $70 \%$ of the Earth's surface and extend to an average depth of $3800 \mathrm{~m}$ (Williams et al., 1973). In this immense environment are found myriad life forms woven into complex webs of interactions both with each other and with their non-living surroundings. Food chains beginning with microscopic phytoplankton extend through many trophic levels, transducing energy and cycling matter (Sumich, 1996). Near or at the very top of these food chains are found the marine mammals - the whales and dolphins, (Order Cetacea) the seals and sea lions, (Order Pinnipedia) the manatees and dugongs (Order Sirenia) (Hall, 1981). Superbly adapted to their aquatic world, these animals are found throughout the seas of the world. Yet as successful as they are, their existence has not been without hazards. Ever since humans first went "down to the sea in ships", they have hunted these creatures for food, oil, and a variety of other products. Such activity has brought many species to the verge of extinction or beyond, as in the case of Steller's sea cow (Hydrodamalis gigas) which was exterminated by Russian hunters by 1770 (Rice, 1977; Slijper, 1977; Bonner, 1990). In addition, their environment has been degraded as humans have 
overexploited their food resources and used the oceans as a dump for all manner of wastes. Toxic chemicals from a variety of human activities have entered the seas where they affect the complex ecosystems in ways both known and unknown (Chiras, 1994).

One group of these chemicals consists of the organochlorines, highly persistent lipid-soluble compounds used in industry and as insecticides. Found throughout the world's oceans, these substances accumulate in organisms and magnify up the food chain, such that top predators can carry extremely high loads (Peterle, 1991). Marine mammals fall into this category of predators, and have been found to carry high concentrations of these substances in their blubber (O'Shea \& Brownell, 1994). It has been shown that in many organisms organochlorines have numerous deleterious chronic effects ranging from lesions and neoplasms to impairments of immunity and reproduction (Reijnders, 1994). The deposition of these harmful substances in marine mammal blubber and their probable damaging effects with metabolic mobilization of blubber certainly put these animals at risk and are cause for concern.

Any person interested in the health, conservation, and longterm survival of these creatures must, therefore, consider the organochlorine burden carried by marine mammals. Knowledge of the magnitude and pattern of occurrence of such burdens is absolutely necessary. It is with this in mind that the following 
study was undertaken. It had four goals. One was to develop a screening method for the determination of the residue levels in blubber of PCB's and p,p-DDE, the two most commonly occurring organochlorines in marine mammals, using high performance liquid chromatography (HPLC). Such a determination has in the past almost always been done using gas chromatography (GC). The second goal was to use the developed HPLC method on marine mammal blubber samples, and evaluate its feasibility as a screening procedure for these two organochlorines. Thirdly, the method was then to be used on a number of samples of different species, especially those from the Pacific Northwest coast, to obtain some idea of the approximate residue levels present. Lastly, the determined levels were to be used to draw some conclusions about the health and movements of the sampled animals, as well as the transfer of these contaminants from mother to offspring. As indicator species, marine mammals and their pollutant loads would also provide some idea of the health of the environment in which they live.

This dissertation reports the results of this study. It begins with a review of pertinent literature that provides a background to the study, followed by two papers which will be submitted for publication. One details the screening method developed and its application. The second summarizes the results and discusses the conclusions drawn from these results. The papers are followed by a summary of the conclusions drawn from the total study, and 
three appendices. The first appendix provides a detailed classification of the marine mammals. The second gives a stepby-step description of the developed screening protocol. The third appendix provides the chromatograms from each sample examined, along with those from recovery determinations and thin-layer chromatography (TLC) confirmations. A bibliography containing each reference cited completes the dissertation. 
CHAPTER II

REVIEW OF RECENT LITERATURE

The organochlorines are a class of compounds which consist of one or more hydrocarbon rings to which varying numbers of chlorine atoms are bonded (Melnikov, 1971). Also known as chlorinated hydrocarbons, a term which technically should apply only to those which are pesticides, these compounds have found use in a variety of applications from potent insecticidal agents to inert industrial fluids and plasticizers (Matsumura, 1975). They are highly persistent, and have been the source of much longlived environmental pollution (Guthrie \& Perry, 1980). The best known and most ubiquitous of these compounds are the polychlorinated biphenyls (PCB's) and dichlorodiphenyltrichloroethane (DDT) and its derivatives (Chiras, 1994). The PCB's are thermally stable compounds which are resistent to acids, bases, and oxidation, and which exhibit excellent dielectric properties. These characteristics led to their widespread use in industry, including use in capacitors, transformers, and fire retardants, and as plasticizers for adhesives, textiles, sealants, and copy paper (Cook, 1972). The general structure of PCB's involves two hydrocarbon rings to which a varying number of hydrogen atoms are replaced by chlorine atoms (Tas \& Kleipool, 1972; 
<smiles>Clc1ccc(-c2ccc(Cl)c(Cl)c2)cc1Cl</smiles>

3,3',4,4'-Tetrachlorobiphenyl<smiles>Clc1ccc(-c2cc(Cl)c(Cl)c(Cl)c2)cc1Cl</smiles>

3,3`4,4',5-Pentachlorobiphenyl<smiles>Clc1cc(-c2cc(Cl)c(Cl)c(Cl)c2)cc(Cl)c1Cl</smiles>

3,3',4,4',5,5'-Hexachlorobiphenyl

Figure 1. Examples of PCB's. 
Figure 1). They have been marketed under a host of names, with the most prevalent being those produced by the Monsanto Chemical Company under the trade name of Aroclor. All Aroclors sold carry a four digit number. The first two digits represent the type of molecule, with 12 indicating a chlorinated biphenyl. The last two digits provide the weight percent of chlorine. Therefore, Aroclor 1254 would be a PCB with 54\% chlorine (Hutzinger et al.,1974). Since there is more information available on the Aroclors than on any other PCB preparations, and since they were produced in such large quantities for so many years, reports of PCB contamination are usually referenced to the Aroclors (Hutzinger et al., 1974).

DDT is the common name for a mixture of substances in which the major component is 1,1,1-trichloro-2,2-bis(pchlorophenyl) ethane. This component is also known as p,pDDT or 4,4-DDT, and its structural formula is given in Figure 2 (Brooks, 1974). This compound is a very potent neurotoxin with its toxicity probably residing in the ability of the trichloromethyl group and the two phenyl groups to freely rotate and assume certain configurations (Martin, 1956; O'Brien, 1967). It is also extremely nonpolar, being practically insoluble in water. This results in DDT being highly lipophilic, and this high level of lipid solubility contributes to its toxic potential (Pryde, 1973). The substitution of chlorine atoms for the hydrogen atoms of the phenyl groups at the 4,4 positions 


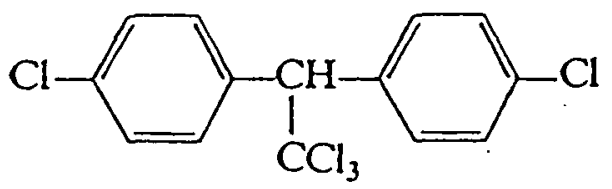

Figure 2. p,p-DDT.

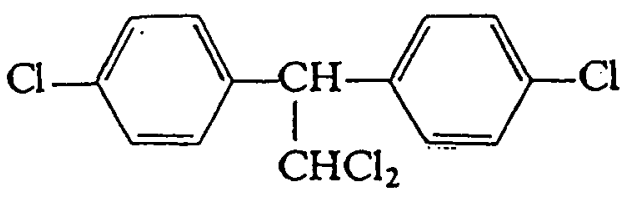

DDD(TDE)

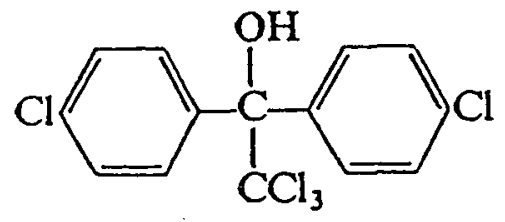

Dicofol

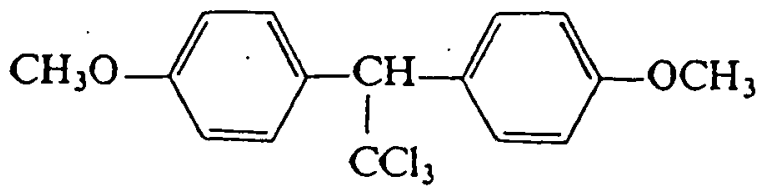

Methoxychlor

Figure 3. Some DDT analogues. 
make the compound very resistent to degradation leading to a high degree of persistence in environments (Focht \& Alexander, 1971). These properties made DDT probably the most widely used single insecticide in history, and spurred the development of analogues such as DDD, methoxychlor, and dicofol (Figure 3). Research produced even more toxic and more persistent organochlorines, such as hexachlorocyclohexane (HCH or lindane), and toxaphene, as well as the various cyclodienes, exemplified by aldrin, heptachlor, and dieldrin (Gunther et al., 1968; Figure 4). Use of DDT was and still is so much greater than that of any of the analogues or derivatives, that residues of organochlorine pesticides encountered in the environment are usually of DDT or one of its metabolites (Chiras, 1994).

PCB's were first synthesized in 1881 , but they did not become commercially available until 1929 (Hutzinger et al., 1974). With the advent of World War II and the increased industrialization both during and after this conflict, the need for the stable, heat-resistent PCB's increased dramatically. Production rose first in the United States and then worldwide, peaking in the early 1970's (Buckley, 1982). When it became apparent that PCB's behaved similarly to the organochlorine insecticides (due to a similarity in structure), and that they were also ubiquitous contaminants in the environment, production was voluntarily restricted and use of PCB's diminished. U.S. production ceased in 


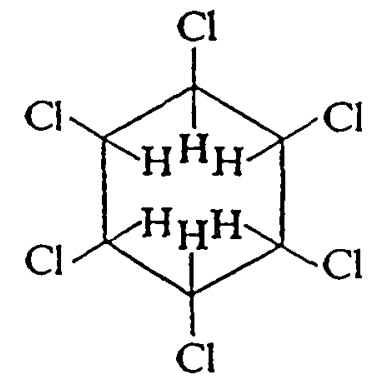

Lindane (Hexachlorocyclohexane or $\mathrm{HCH}$ )

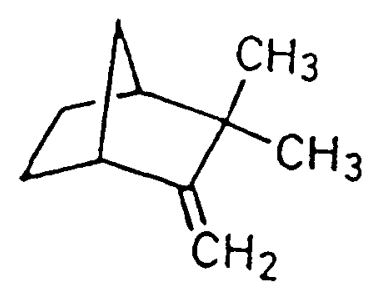

Toxaphene

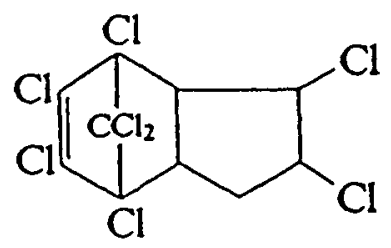

Chlordane

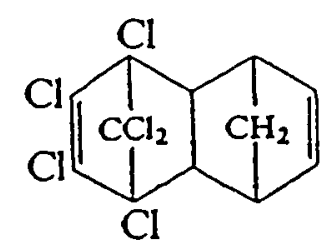

Aldrin and Isodrin

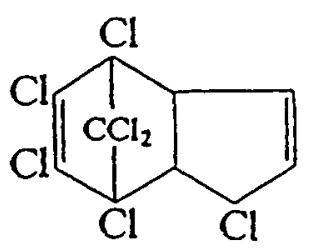

Heptachlor

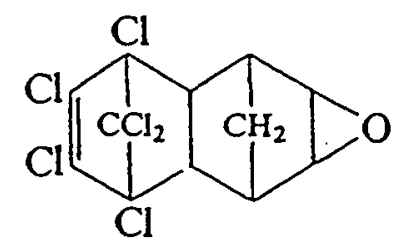

Dieldrin and Endrin

Figure 4. Lindane, toxaphene, and some cyclodienes. 
1977 , and PCB use was banned in 1979. Production may still be continuing in other countries such as Japan and Germany (Peterle, 1991).

The organochlorine pesticides made their commercial appearance during World War II following the discovery of the insecticidal properties of p,p-DDT by Muller in Switzerland in 1939 (Brooks, 1974). Spurred by the need for potent insectcontrolling agents in war-torn Europe and Asia, production of DDT began in earnest in Great Britain and the U.S. in 1943. Its first large-scale use was in December of that year when it was used to control a typhus outbreak in Naples, Italy (West \& Campbell, 1950). Its success there did much to establish its early reputation as a wonder chemical, and following the war production soared. It came to be used for a wide range of applications, from controlling insects which carried disease to killing off plant pests on farms and in forests (Rudd, 1964; McEwen \& Stephenson, 1979). Production peaked in the U.S. in 1961 and worldwide in 1964. At that time approximately 400,000 tons of DDT were being used annually throughout the world, along with lesser amounts of the newer DDT analogues and cyclodienes (Brooks, 1974). Even though the detrimental effects of these compounds on wildlife had been known since the 1950's, it wasn't until the publication of Rachel Carson's book, Silent Spring (1962), that the general public became aware of the dangers posed by these organochlorine pesticides (von den Bosch, 1969). Opposition to these substances 
mounted until 1972, when general use of DDT and other members of the so-called "dirty dozen" (e.g., aldrin, dieldrin, heptachlor) was banned in the U.S. Most other developed countries quickly followed suit (Keith, 1991). Developing nations, especially those in tropical regions, have continued to use organochlorines, particularly DDT, for both agricultural and public health purposes. Production has also shifted to these countries, and demand for these cheap and relatively effective pest control agents is likely to continue for some time (Dikshith, 1991a).

The enormous past production, and to a lesser extent, current production and use of organochlorines resulted in the deposition of large quantities of these compounds into the environment. As an example, Tanabe (1985) estimated that the total PCB residue in the environment amounted to $370 \times 10^{3}$ tons in 1985. Since PCB's were generally used in industrial applications, their entry into the environment usually came from point sources, such as place of manufacture, use, and disposal (Schmidt, 1994). This last source, usually landfills, is currently the greatest source of PCB pollution in most of the world (Beeton, 1979; Tanabe, 1988). Some PCB residue also entered the environment as a result of deliberate dumping into waterways, such as occurred in the Hudson and Rhine rivers (Koeman et al., 1969; Clesceri, 1980). Even though banned in most areas of the world, PCB's still enter the environment through approved incineration, leaking legal and illegal landfills, and from illegal 
dumping (Postel, 1988). In addition, large amounts also still reside in older electrical equipment. The potential amount that could enter the environment has been estimated to be double the amount present in 1988 (Tanabe, 1988).

Although produced and used mainly in the industrialized nations, contamination by PCB's is not limited to these areas. It has been pointed out that, as would be expected, the earliest and most severe cases of PCB pollution occurred in the more developed countries. However, these contaminants are now found worldwide, in concentrations often comparable to those found in industrialized nations where restrictions and bans have been in place for almost twenty years (Phillips, 1994; Tanabe et al., 1994). Once PCB's enter the environment they are transported mainly by the movement of air and water, with smaller amounts carried by migratory animals (Bowes \& Jonkel, 1975; George \& George, 1994). This is evident from the occurrence of these contaminants in relatively pristine regions, such as the Arctic and Antarctic (Risebrough et al., 1976; Cotham \& Bidleman, 1991; Barrie et al., 1992). Of the organochlorines, the PCB's have a relatively higher vapor pressure with that of Aroclor $1254=3.0 \times 10^{-5} \mathrm{~mm} \mathrm{Hg}$ at $20^{\circ} \mathrm{C}$, as compared to DDT whose vapor pressure at $20^{\circ} \mathrm{C}$ is $1.5 \mathrm{X}$ $10^{-7} \mathrm{~mm} \mathrm{Hg}$ (Wania \& Mackay, 1993). Because of this the PCB's have a greater tendency to volatilize from their point of origin and be dispersed throughout the world on global air currents (Bidleman \& Olney, 1974; Tanabe, 1988; Wania \& Mackay, 1993; 
Tanabe et al., 1994). They are then deposited onto the Earth's surface through precipitation and settling (Ware \& Addison, 1973; Kleinow \& Goodrich, 1994). This seems to be the mechanism by which PCB's have contaminated remote regions, as well as certain enclosed bodies of water such as the Great Lakes (Swain, 1980; Strachan et al., 1980; Oehme, 1993). Deposition into the oceans also occurs in this fashion, but is augmented by inflow from PCBcontaminated rivers and streams (Claeys et al., 1975; George \& George, 1994). Lower chlorine percentage PCB's exhibit greater water solubility, and water transport is probably the most common method of dispersal for these residues. In addition, PCB's strongly adsorb onto silt particles and are transported in this fashion in waterways (Hutzinger et al., 1974). Rivers polluted with PCB's clear rapidly, depositing their contaminants most often in coastal marine environments and, to a lesser extent, lakes (Loganathan \& Kannan, 1994). It is estimated that the oceans currently contain over $60 \%$ of the world's environmental PCB load. The seas are, therefore, both a huge reservoir and the final sink for most of the PCB pollution on Earth (Tanabe, 1988; Tatsukawa \& Tanabe, 1990; Tanabe et al., 1994). Even though concentrations are extremely low in the seawater and sediments, organisms that can accumulate PCB residues over time must be considered at risk.

The chlorinated hydrocarbon insecticides have also entered the environment in enormous amounts. As an example, 400 million pounds of insecticides were used in the U.S. alone in 1964, 
of which approximately one-half were DDT and the cyclodienes (Matsumura, 1975). It has been estimated that during the height of organochlorine pesticide use in the 1960's, the Mississippi River transported 10,000 kilograms per year of pesticides to the Gulf of Mexico, the largest portion of which were DDT and cyclodienes (Risebrough et al., 1968). Although most countries in the northern hemisphere banned the use of these substances in the 1970's, they are still being used heavily in some areas of the tropics and south of the equator, an occurrence labeled the "southward tilt" by Goldberg (1991). This past and continuing entry into the environment occurs usually by the spraying of liquids, wettable powders, or emulsions of the agents to an area to control insects that pose threats to agriculture or public health. More durable formulations such as granules may also be used (Brooks, 1974). Deliberate dumping of large quantities has also occurred, as exemplified by the high amount of DDT found off the Los Angeles county sewer outfall which originated with the Montrose Chemical Company plant which produced DDT (Burnett, 1971). The spraying and dusting of DDT and its relatives results in their deposition on soil, plants, water bodies, and into the air. The act of spraying, especially large-scale aerial spraying spreads the insecticide over wide areas of soil or water, with considerable amounts failing to even reach the ground where it was targeted (Raven et al., 1995). 
When it finally does come down to earth, an organochlorine insecticide generally ends up in the soil. What falls on plants is rarely assimilated. Instead, it is deposited in the soil as a result of either being washed off the plants, or being released when the plant dies and falls to the ground (Hull, 1970). If the absorptive ability of the soil is low, as with sand, and/or the plants have extensive root systems, then some of these insecticides can migrate into plant tissues and accumulate, even though their water solubilities are low (Lichtenstein et al., 1967a). These conditions rarely occur where these substances are used, though, as agriculture is almost always practiced where the soil contains varying amounts of organic matter which tends to absorb and bind organochlorines (Lichtenstein \& Schulz, 1960). Generally speaking, these pesticides persist longer in soils with higher clay content, that are more acidic than alkaline, and that are cultivated at infrequent intervals (Lichtenstein \& Schulz, 1961; Carter \& Stringer, 1970). For these reasons most of the applied insecticides remain in the upper horizons of the soil, with little percolating down to lower levels (Lichtenstein et al., 1967b). They are, therefore, available for transport away from the site of application. Because of their low vapor pressures, the volatization of DDT and its analogues is not great. Many of the cyclodienes, however, do disappear appreciably from soils over time due to their higher volatilities (Acree et al., 1963). Even DDT can enter the gaseous phase if water is present in the soil and air, as the 
water facilitates the movement of the pesticide to the surface, and helps to desorb it from the soil particles (Spencer et al., 1973). A certain amount also remains in the air following spraying. In temperate and/or drier regions the main route for DDT and some of the cyclodienes to the atmosphere is by airborne dust. These insecticides adsorb strongly to soil particles, remain unchanged for some time, and as the soil dries it is picked up and blown as dust for hundreds of miles, carrying the contaminants with it (Cohen \& Pinkerton, 1966; Risebrough et al., 1968). Combined with volatilization, this process allows the chlorinated hydrocarbons to enter the atmosphere and be distributed worldwide (Hurtig, 1972). No part of the Earth is free from such pollution, as shown by the presence of DDT and the cyclodienes in areas as remote as the polar regions (Tatton \& Ruzicka, 1967; Risebrough et al., 1976; Wania \& Mackay, 1993). Even though these compounds are now only rarely used in some northern hemispheric countries, the air north of the equator still exhibits concentrations of the same order of magnitude as that of the atmosphere south of this line (Goldberg, 1991; Preston, 1992). This is due to the continued use of the organochlorines in warm tropical regions, where they are evaporated more rapidly than in temperate climates, and are transported northward on air currents, along with organochlorines carried on dust particles (Tanabe, 1991; Oehme, 1993; Wania \& Mackay, 1993). No matter where they are carried, these insecticides are ultimately cleared from the atmosphere, primarily 
through a washing-out process by rain or snow (Tarrant \& Tatton, 1968; Kleinow \& Goodrich, 1994). Most of this precipitation occurs over the oceans, providing the major route of contamination of the marine environment, especially of the pelagic zones (Loganathan \& Kannan, 1994).

DDT and the cyclodienes also enter the water environment both directly through spray drift and deliberate application over water bodies, and indirectly with runoff from terrestrial areas (Rudd, 1964; Stoker \& Seager, 1977). The erosive effects of water are quite pronounced, with large amounts of insecticides carried with the tons of topsoil washed off each year from agriculiural areas (Lichtenstein et al., 1967b; Klinkenborg, 1995). Legal and illegal dumping of these substances into rivers and lakes has also occurred in the past (Cunningham \& Saigo, 1992). Upon reaching water bodies most of the DDT and other low solubility pesticides are found bound to solid particles and are transported in this fashion; little is found dissolved in the water (Miles, 1980; Peterman et al., 1980). Moving water carries such pollution to areas where water movement is slowed. Therefore, lakes and coastal areas of the oceans are the ultimate regions of deposition of the organochlorines carried by water (Duinker, 1985; Iwata et al., 1993). Together with atmospheric fallout, water movement results in lakes and oceans being the sink of all such contaminants, although some may remain permanently in terrestrial soils (Hom et al.., 1974; Loganathan \& Kannan, 1994). 
Once in these sinks, organochlorine insecticides, as well as PCB's, remain for a time suspended in the mixed layers before finally settling out to the bottom (Woodwell et al., 1971). Thus, the ultimate repository for DDT, its analogues, and the cyclodienes is the terrestrial soil and the aquatic sediments, with the latter containing the majority of the residues. Breakdown to non-toxic metabolites is extremely slow in these areas, so the organochlorine insecticides will be available for many years in aquatic environments, especially the oceans (Patin, 1982; Larsson, 1984). As with the PCB's, organisms present in such environments with the capability of accumulating residues of these compounds have been and will continue to be susceptible to their long term detrimental effects (Tanabe et al., 1994).

What happens to the organochlorines once they get into the environment? Because of their structural similarities, the fates of PCB's and the chlorinated hydrocarbon insecticides are similar, as are their primary modes of transport and ultimate sites of deposition (Connell \& Miller, 1984). They are persistent compounds in the environment, which means they are resistent to physical and biological breakdown. It has been shown that the cyclodienes can be rearranged intramolecularly by the action of ultraviolet light to form isomers, such as the caged compounds photoaldrin and photodieldrin from aldrin and dieldrin, respectively (Rosen et al., 1966; Rosen \& Sutherland, 1967). DDT appears to slowly degrade into DDE (dichlorodiphenyl- 
dichloroethylene; Figure 5) in the presence of light and air, and this in turn can be converted to DCBP (dichlorobenzophenone; Figure 5) and other substances (Matsumura, 1975). DDE is more volatile than DDT, and this increased volatility increases the overall loss of DDT from soils to air, and contributes to its aerial dispersion (Cliath \& Spencer, 1972). PCB's photolyze in the presence of sunlight to give products formed by the loss of chlorine and rearrangement (Safe \& Hutzinger, 1971). Organochlorines, in general, do not persist as long in water and soils that are alkaline or that have high concentrations of sodium carbonate (Peterle, 1991). Outside of these modifications, organochlorines remain basically unchanged by the physical environment; indeed, this property was one of the main reasons for their initial and continued popularity (Ramade, 1987). Most of the changes that occur in these substances come about as a result of the activities of the biotic environment. For instance, DDT is degraded by microorganisms through reductive dechlorination to yield DDD (dichlorodiphenyldichloroethane; Figure 5), which is then further broken down (Matsumura et al., 1971). Under aerobic conditions bacteria utilize oxidation reactions to metabolize DDT to dicofol (Figure 3), and produce DDE from DDT by dehydrochlorination (Matsumura \& Boush, 1968; Keil $\&$ Priester, 1969). Due to the stability provided by the presence of the chlorine atoms at the p,p positions, cleavage of the aromatic rings by microorganisms is uncommon (Focht \& Alexander, 1971). 


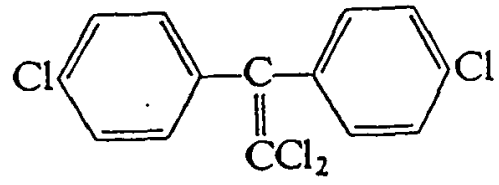

$\mathrm{p}, \mathrm{p}-\mathrm{DDE}$<smiles>Clc1ccc(C(c2ccccc2)C(Cl)Cl)cc1</smiles>

$\mathrm{p}, \mathrm{p}-\mathrm{DDD}$<smiles>O=C(O)C(c1ccc(Cl)cc1)c1ccc(Cl)cc1</smiles>

$\mathrm{p}, \mathrm{p}-\mathrm{DDA}$<smiles>ClC=C(c1ccccc1)c1ccc(Cl)cc1</smiles>

$p, p-D D M U$<smiles>O=C(c1ccc(Cl)cc1)c1ccc(Cl)cc1</smiles>

p,p-DCBP(Dichlorobenzophenone)

Figure 5. Metabolites of p,p-DDT. 
Cyclodienes often undergo epoxidation reactions in organisms, with aldrin being converted to dieldrin, heptachlor to heptachlor epoxide, and isodrin to endrin (Lichtenstein \& Schulz, 1960). This is relatively common among microorganisms, and may give them the opportunity to further degrade these compounds (Matsumura, 1982). PCB's are also generally degraded by a variety of microorganisms to more polar metabolites, but the rate of degradation decreases with increasing chlorine content (Gibson, 1968; Hutzinger et al., 1974). This same result is found in more complex organisms (Parke, 1968). PCB's, however, may be more resistant to degradation by organisms, including bacteria, than is DDT and its analogues due to the absence of the ethane component between the aromatic rings, which is the site of most transformations of DDT (Peakall \& Lincer, 1970).

Breakdown of organochlorines also occurs in other heterotrophic organisms. As an example, the fungus Mucor alternans degrades DDT into water-soluble metabolites (Anderson \& Lichtenstein, 1971). Animals also metabolize DDT and PCB's, but the pathways and products differ from species to species (Brown, 1978). In the rainbow trout (Salmo gairdneri), p,p-DDT is degraded quickly to DDE and more slowly to DDD and DDMU (Figure 5), while in the Atlantic salmon ( $\underline{\text { Salmo }} \underline{\text { salar) }}$ p,p-DDT is degraded mainly to p,p-DDD (Cherrington et al., 1969; Addison, 1978). The major DDT metabolite in insects is DDE, whereas the earthworm (Pheretima posthuma) quickly produces DDD and DDE 
from DDT (O'Brien, 1967; Agarwal et al., 1978). As with bacteria, the cyclodienes are generally degraded through epoxidation, although some other metabolic pathways may be possible in some insects (Bowman et al., 1964; Brooks \& Harrison, 1965). PCB degradation by animals occurs such that certain components of a technical PCB mixture, like Aroclor 1254, are preferentially metabolized over others (Albro \& Fishbein, 1972; Bailey \& Bunyan, 1972). Fish metabolize PCB's very slowly, while birds and mammals do so more quickly (Bagley \& Cromartie, 1973; Fries et al., 1973). In most species the metabolites are predominantly hydroxy compounds (Hutzinger et al., 1974). Birds generally degrade DDT to DDE, although some species produce DDD instead of DDE (McEwen \& Stephenson, 1979). Among mammals the metabolism of DDT and its analogues varies with the species. Humans produce mainly DDE, cattle (Bos taurus) and deer (Odocoileus virginianus) mainly DDD, and rats (Rattus rattus) and mice (Mus musculus), DDA (Figure 5) and DDD (Fang et al., 1977; Fries, 1977; Kurtz \& George, 1977; Kaloynova \& El Batawi. 1991). Pigs ( $\underline{\text { Uus scrofa) }}$ produce DDE, further metabolize it to a methoxy compound, and excrete it in the feces. DDT is also metabolized in pigs to DDA, which is excreted in the urine (Sundstrom et al., 1977). Interestingly, Rhesus monkeys (Macaca mulatta) produce no DDE at all (Durham et al., 1963; Hayes, 1965). Grey seals (Halichoerus grypus) degrade DDT to DDE slowly, then produce DDE methyl sulfones (Jansson et al., 1975). PCB methyl sulfones have 
also been found in the grey seal, as well as in the beluga (Delphinapterus leucas), the river otter (Lutra lutra), and the mink (Mustela vison), indicating their formation from PCB's (Haraguchi et al., 1992; Bergman et al., 1994). In all these processes of biotransformation it must be kept in mind that the products may not necessarily be nontoxic, and the processes not necessarily those of detoxification (Reijnders, 1994). For instance, DDE is often more toxic over the long term than its parent compound, a disturbing fact when it has been shown that DDE is usually the most common organochlorine pollutant found in wildlife specimens (Jeffries, 1975). Likewise, photoaldrin and heptachlor epoxide are much more toxic than aldrin and heptachlor respectively (Brooks et al., 1963; Matsumura, 1982). Assessment of risks to organisms from organochlorines must therefore take into account the presence of transformation products as well as the compounds themselves.

On entering the environment, organochlorines can have many fates, one of which is to enter organisms. There are three main routes of entry into living things: ingestion, inhalation, and through the epidermis (Peterle, 1991). The last route is the one most often found in insects, especially in areas of the body where the cuticle is thin (Lewis, 1965). Insects do, however, take up these substances through the tracheal system and the mouthparts, although to a lesser extent than through the skin (Quraishi \& Poonawalla, 1969). Ingestion is the most common route of entry for most terrestrial animals, while plants can take up some 
organochlorines, such as aldrin and lindane, through their roots (Lichtenstein \& Schulz, 1960; Shimabukura et al., 1982). Animals can ingest these contaminants directly, as with earthworms ingesting contaminated soil particles, herbivores feeding on treated foilage, or birds eating dressed seeds (Barker, 1958; Robinson, 1969). They can also ingest other animals which have taken in the substances. Often this may be even more deadly than ingesting the contaminant directly, as some metabolic products are more toxic than the parent compounds and accumulation of these substances may have taken place in the animal prior to its being eaten (Dempster, 1975; Peterle, 1991). In aquatic systems, only dermal and ingestive uptake are important. Invertebrates, fish, and amphibians absorb organochlorines directly across the respiratory surface, either the gills or skin, and tend to reach an equilibrium with the concentration in the water rather quickly (Eberhardt et al., 1971; Moriarty, 1972; Matsumura \& Benezet, 1973; Miyamoto et al., 1979). In addition, these organisms can take contaminants up through feeding (Holden, 1975). Aquatic birds, reptiles, and mammals take in these substances almost entirely by ingestion (Neilson, 1994). Even though practically all studies have concentrated on the chlorinated hydrocarbon insecticides, it is felt that the uptake of PCB's is similar, due to their similar structures and properties (Risebrough, 1969). Because of their greater occurrence in aquatic ecosystems, entry of PCB's into organisms 
occurs to a much greater extent among aquatic species than terrestrial ones (Tanabe, 1988; George \& George, 1994).

In addition to being taken in by organisms, the organochlorines are also accumulated in tissues. This is due to their resistance to breakdown (i.e., their persistence) and to their lipophilic nature, which allows them to be stored in lipid compartments where much enzymatic breakdown is absent (O'Brien, 1967). Over time, organisms can build up high concentrations of these compounds even though environmental leve's at any one time are low (McEwen \& Stephenson, 1979; Connell \& Miller, 1984; Smith \& Hall, 1994). Although many factors are involved, such bioaccumulation occurs whenever the rate of uptake is greater than the rate of metabolism and excretion (Matsumura ,1975; Tanabe, 1988). The amount of accumulation in aquatic systems is often expressed in terms of a bioaccumulation ratio, which equals the concentration in the organism divided by the concentration in the water at any given time. As an example, rainbow trout placed in water containing 0.01 parts per million (ppm) of DDT exhibited a bioaccumulation ratio of 2700 after 14 days (Miyamoto et al., 1979). It is usually found that such accumulation is greater in aquatic than in terrestrial environments, as evidenced by the higher ratios in the former. For instance, terrestrial invertebrates exhibit ratios of $0.31-73$, while for those in water the values are $144-70,000$ (Edwards, 1970; Kenaga, 1972). In addition, bioaccumulation 
occurs to a greater extent the higher one goes in the food web, a phenomenon known as biomagnification (Chiras, 1994). This occurs in both terrestrial and aquatic ecosystems, although the latter have been more thoroughly studied. Hickey et al. (1966) studied Lake Michigan and obtained the results for total DDT = DDT+DDE+DDD that are illustrated in Table I. Similar results were obtained from a marine ecosystem for DDE as shown in Table II. These results illustrate an important point regarding biomagnification, which is that some lower trophic levels may actually exhibit higher residue levels than are found in higher trophic levels. Even in these cases, however, the general pattern of increased accumulation further up the food chain is borne out. Similar patterns are found in terrestrial ecosystems (Stickel, 1968; Korschgen 1970). Accumulation of residues in organisms occupying the top of any food chain can be remarkable. PCB's were found at concentrations up to 7990 ppm in Hudson River snapping turtles (Chelydra serpentina), while p,p-DDE occurred at a level of $2678 \mathrm{ppm}$ in a California sea lion (Zalophus californianus (Le Boeuf \& Bonnell, 1971; Stone et al., 1980). Such high levels are usually found in fat or blubber tissue, where residues can be sequestered without toxic effects. If these reserves are mobilized during times of stress, however, the effect can be lethal, as evidenced by a merlin (Falco columbarius) found dead during the autumn migration which exhibited brain residues of $\mathrm{p}, \mathrm{p}-\mathrm{DDE}$ of 1800 ppm (Van Velzen et al., 1972; Henny et al., 1976). 
TABLE I

TotalDDT (DDT+DDE+DDD) in LakeMichigan

Sediments: $0.014 \mathrm{ppm}$

Amphipods: $0.41 \mathrm{ppm}$

Fish: $4.5-5.6 \mathrm{ppm}$

Herring Gulls: 99 ppm (breast muscle)

Herring Gulls: 2441 ppm (fat)

from Hickey et al. (1966)

TABLE II

DDE in a Marine Ecosystem

\begin{tabular}{|c|c|c|}
\hline Tophic Level & Group & Concentration \\
\hline 1 & Seaweed & $0.002 \mathrm{ppm}$ \\
\hline 2,3 & $\begin{array}{l}\text { Microzooplankton \& } \\
\text { Invertebrates }\end{array}$ & $0.04 \mathrm{ppm}$ \\
\hline 3 & Macrozooplankton & $0.16 \mathrm{ppm}$ \\
\hline 3,4 & Fish & $0.02 \mathrm{ppm}$ \\
\hline 4,5 & Sea Birds & $0.5 \mathrm{ppm}$ \\
\hline 5 & Sea Mammals & $0.25 \mathrm{ppm}$ \\
\hline
\end{tabular}

from Robinson et al. (1967) 
Since organochlorines are taken in and accumulated by organisms, it has become vitally important to know the effects of these compounds on living things. The insecticides were first developed as poisons to kill insects, so their effects must be detrimental at high enough concentrations (Parr, 1987). The PCB's were not developed to be biocidal, but due to their similarities to the insecticides, they are also detrimental at certain concentrations (Fishbein, 1972). The effects of these compounds can be considered at four different levels. The first of these is the acute lethal effect. These effects occur whenever the concentration of the organochlorine is high enough in one application to produce death (Brooks, 1974). These concentrations are usually expressed as the median LD50, which is a statistical estimate of the concentration at which one-half of a large experimental population dies (Dikshith, 1991a). This acute toxicity data has been compiled for a number of species, especially for the organochlorine insecticides, and varies depending on the species and insecticide (Jager, 1970; Briggs, 1992). For example, the LD50 in laboratory rats for DDT is $250 \mathrm{mg} / \mathrm{kg}$, for aldrin it is $38-67 \mathrm{mg} / \mathrm{kg}$, and for endrin, one of the most toxic chemicals known, it is $7-18 \mathrm{mg} / \mathrm{kg}$ (Vershueren, 1983). This is for oral ingestion; values for dermal uptake by rats are higher. For mallard ducks (Anas platyrhynchos) the values are $2240 \mathrm{mg} / \mathrm{kg}$ for DDT, $381 \mathrm{mg} / \mathrm{kg}$ for dieldrin, and $5.64 \mathrm{mg} / \mathrm{kg}$ for endrin (Tucker \& Crabtree, 1970). The LD50 in laboratory rats for 
Aroclor 1260 is $10,000 \mathrm{mg} / \mathrm{kg}$, indicating that the acute toxicity of PCB's is not nearly as great as that of the insecticides (FDA, 1970). Even though similar values have been reported for most of the Aroclors in rats, investigators consider the acute toxicity of PCB's for humans to be moderate to high (Sax ,1955). LD50 values for insects, the target organisms of the insecticides, are much lower, with that for DDT in houseflies being $0.24 \mathrm{ug} / \mathrm{fly}$ (Holan, 1971).

The insecticides are potent neurotoxins, acting primarily by prolonging neuronal membrane depolarization through the interference of the sodium and chloride channels (Narahashi, 1987). With high enough concentrations the nervous system is disrupted to such a degree that the animal dies (Matsumura, 1975). Although the amounts needed to accomplish this in insects were initially very low, widespread use of these substances, coupled with rapid reproductive rates of insects, led to the development of resistant strains and the need for higher doses used more often (Brown \& Pal, 1971). Because of this, the number of incidences of acute poisoning of non-target organisms increased dramatically from the 1950's to the 1970's (Keith, 1991; Weber, 1992). For example, thousands of birds were killed in Britain from 1956-1960 by ingesting seeds dressed with high concentrations of aldrin, dieldrin, and heptachlor (Bunyan \& Stanley, 1983). The use of endrin for rodent control in Washington state orchards as recently as 1983 resulted in the deaths of a wide variety of birds including songbirds, owis, and 
game birds (Blus et al., 1989). Gray bats (Myotis grisescens) were killed in the hundreds in Missouri as a result of dieldrin treatments in fields adjacent to their caves (Clark et al., 1983). With the ultimate banning of the organochlorine insecticides by many nations, such acute poisoning in the northern hemisphere declined rapidly. However, such incidents probably still do occur with high frequency where these substances are still in use (Keith, 1991; Weber, 1992). Acute lethal effects of PCB's have been rarely reported outside of the laboratory, due to the lower toxicity of these compounds, and the absence of their use outside of industry. Because of their widespread occurrence in aquatic environments, acute poisoning by PCB's is probably limited to fish and other aquatic organisms (Eisler, 1986).

The second level of effect is that of acute sublethal. In this case, one application of or contact with the organochlorine interferes with the normal life processes, but does not cause death (Wills, 1969). These effects have been observed in the laboratory, but rarely in the field (Peterle, 1991). Acute sublethal effects generally involve the nervous system, although other organs may be affected. For instance, animals acutely poisoned by organochlorines first exhibit hyperexcitation, muscular twitching, and weakness. This is followed by tremors and varying degrees of paralysis. The animal then recovers over a period of hours (Dikshith, 1991b). In humans, the onset of acute effects begins within one hour, starting with nausea, vomiting, and diarrhea. 
This is followed by headache and dizziness. Tremors then occur followed by paralysis. Recovery again takes place over hours, with longer-term damage to kidneys, liver, and the production of white blood cells. If the poisoning is severe enough, convulsions, coma, and respiratory failure occur, resulting in death (Kaloyanova \& El Batawi, 1991). The same effects are observed in other animals. The determination of whether acute effects are lethal or sublethal is, therefore, based on the concentration of the organochlorine (Kilgore \& Li, 1976). Acute sublethal effects may also result in death. For instance, an animal exhibiting the abovementioned symptoms may move erratically and noticeably, attracting the attention of a predator which then kills the affected animal (Dempster, 1975). Long term tissue damage from the single incident of poisoning may result in a shortened lifespan for the organism also. In any event, acute effects are clearly detrimental, whether they be lethal or just debilitating.

Outside of the areas where they are currently being used, the acute effects of the organochlorines are probably rarely observed, and play little part in the size and overall health of populations (Francis, 1994). This is not the case with the chronic or long-term effects of these substances. Such effects come about with either repeated exposure to sublethal concentrations, and/or the accumulation of these substances in tissues over time (Kilgore $\& \mathrm{Li}, 1976)$. Because the organochlorines are so persistent, these two origins of chronic toxicity probably operate together, since 
most affected organisms are constantly exposed to low levels in their environment or food and accumulate these substances to a greater or lesser extent (Peterle, 1991). This results in levels of contamination that are high enough to have long-term effects (Matsumura, 1975). As with acute toxicity, there are two levels of chronic effects, lethal and sublethal. If the effects are severe enough over time to cause the death of the organism or shorten its life expectancy, then it can be considered a chronic lethal effect. If, however, it does not alter the organism's life span, but just reduces its quality of life or reproductive ability, then it can be considered chronic and sublethal (Guthrie \& Perry, 1980). In studying organisms in the field this distinction is often blurred, since an effect which does not appear at the time to be harming the individual may actually be lethal (Berg, 1969). It is therefore common to document chronic effects together, whether they be lethal or sublethal (Moriarty, 1983; Francis, 1994).

One of the major cellular effects of the organochlorines is the enhancement of the mixed function oxidase system (Hayes, 1975). This is a system of enzymes located in the smooth endoplasmic reticulum of liver cells, as well as cells of the kidney, lungs, intestines, and adrenal glands (Zubay, 1986). This system is involved in the transformation of xenobiotics, with one of its major components being cytochrome P-450 (Popov \& Blaauboer, 1991). Induction of the system is generally measured by enlargement of the liver and an increased amount of this 
cytochrome (Yarbrough et al., 1982). Such induction can have a variety of effects from liver hypertrophy to the more rapid breakdown of circulating hormones in the body (Lustick et al., 1973; Hodgson \& Tate, 1976). This alteration in the endocrine system can result in disruptions in feeding, reproductive behavior and functioning, and response to disease (Luoma, 1995). These disruptions in turn can cause a decline in animal populations. DDT, dieldrin, and mirex, along with PCB's, have been shown to be inducers of the mixed function oxidase system (Walker et al., 1972; Kaminsky et al., 1978; Yarbrough et al., 1982; Brunstrom, 1992). Many of the other chronic effects of the organochlorines may actually be due to their induction of this system of enzymes (Conney, 1967).

Physiologically, long-term exposure to these contaminants produces several detrimental effects. These include increased incidence of liver tumors in mammals, and kidney and spleen damage in birds (Peakall \& Lincer, 1970; Tomatis et al., 1972; Dikshith, 1991c; Bergman et al., 1992). Brandt et 리. (1992) demonstrated adrenocortical damage from cytotoxic intermediates of DDT metabolism, while teratogenic and carcinogenic effects have been reported for both PCB's and the insecticides (McLaughlin et al., 1963; Fishbein, 1976). Mutagenicity as a result of chronic DDT and DDE exposure has also been reported (Johnson \& Jalal, 1973; Kelly-Garvert \& Legator, 1973; Cory et al., 1974). In a study of a natural population of mice (Mus musculus) in the 
Andean foothills, DDT was suspected as being the causal agent of the abnormally high number of mutants observed (Wallace, 1971). Being neurotoxic, it is not surprising that the organochlorine insecticides have been shown to have profound nervous system effects. Brain-lipid metabolism is significantly changed and degeneration of the cerebellum is noticed, along with optic atrophy (Haymaker et al., 1946; Misra et al., 1985; Sanyal et al., 1986). Parsons \& Peterle (1977) illustrated deleterious effects to the parathyroid gland from DDE, while Jeffries \& French (1971) showed DDT exposure to result in significant changes in the thyroid gland. Indeed, Jeffries (1975) presents evidence to support the hypothesis that most of the chronic organochlorine insecticide effects in birds and mammals can be explained on the basis of alteration of the thyroid gland and changes in circulating vitamin A brought about by these substances. Interestingly, mink exposed to PCB's over time were also found to have lower concentrations of vitamin A (Hakansson et al., 1992). PCB's and DDT have been shown to disrupt osmoregulation in aquatic species, with some evidence indicating an interference by DDE with salt gland functioning in some species of birds (Kinter et al., 1972; Waggoner \& Zeeman, 1973, Rattner et al., 1983). Organochlorines also appear to suppress the immune system (Street \& Sharma, 1975). Friend \& Trainer (1970) reported that mallard ducklings fed PCB's had higher mortalities when exposed to duck hepatitis virus than those fed no PCB's. Rats fed DDT 
exhibited a decrease in antibodies to ovalalbumin when challenged with the protein (Wasserman et al., 1969). Kendall et al. (1992) showed that organochlorines caused thymus gland atrophy in grey seals and harbor seals (Phoca vitulina), resulting in impaired cell-mediated immunity. Disruptions of endocrine system functioning by these contaminants can also result in immune system dysfunction (Wiltrout et al., 1978).

One of the main chronic effects of organochlorine exposure is on the reproductive system. This is manifested in the phenomenon of thinner eggshells and consequent increased breaking during incubation by birds. This was first reported by Ratcliffe (1967) and later expanded upon by Peakall (1970). The primary causative agent appeared to be DDE, and the mechanism of its action has been hypothesized by many authors (Bitman et al., 1969; Cooke, 1973; Haegele \& Tucker, 1974; Kolaja \& Hinton, 1979). In addition, some of the decline in nesting success appeared to be the result of erratic incubation behavior brought on by organochlorines, as demonstrated in the treatment of ring doves ( $\underline{\text { Streptopelia }}$ risoria) with PCB's (Peakall \& Peakall, 1973). Interference with the endocrine system by these contaminants is probably also involved in poor reproductive success. DDT and PCB's have both been shown to be estrogenic, mimicking female hormones in many vertebrate species, while DDE appears to act as an androgen blocker (Bitman \& Cecil, 1970; Culotta, 1995). Sexual reproduction is impaired as affected males fail to develop mature 
sexual organs, and exhibit female behavior (Fry \& Toone, 1981). Chronic exposure to DDT has also been shown to disturb spermatogenesis (Biswas et al., 1981). In addition, exposure to organochlorines also affects pregnant females. For example, Edqvist et al. (1992) showed that pregnant mink fed PCB's exhibited biochemical changes that indicated disturbances in hepatocytes. PCB's also resulted in marked changes in female reproductive organs and a much higher number of fetal deaths in pregnant minks (Backlin \& Bergman, 1992). The toxic effect to the fetus is probably more pronounced at the time of implantation and later (Madej et al.., 1992). Mink fed DDE also exhibited high embryonic losses (Gilbert, 1969). Subnormal reproduction has also been demonstrated in dogs (Canis familiaris) and Rhesus monkeys fed DDT and PCB's respectively (Deichmann et al.., 1971; Allen \& Barsotti, 1976). It has been shown that organochlorines can cross the mammalian placenta (Backstrom et al., 1965; Wasserman et al., 1967; Hart et al.., 1972). Embryonic development can thus be impaired, and young can be born carrying large loads of these contaminants (Grant et al., 1971; Orberg, 1977). Similar high loads have been detected in newlyhatched birds (Blus, 1984; Ohlendorf et al., 1985).

Acute and chronic effects of organochlorines have combined to decimate many wildlife populations. Birds of prey in England were drastically reduced in numbers as a result of poisoning that originated with seed dressings in the late 1950's, and their 
recovery has been extremely slow due in large part to poor reproductive success from continued exposure to sublethal levels of organochlorines (Ratcliffe, 1963; Prestt, 1965; Prestt et al., 1970; Ratcliffe, 1970). With the banning of most of these substances in many countries, acute effects have become rare, but chronic effects continue due to the persistence of these compounds. Slow recovery of peregrine falcon (Falco peregrinus) populations has been linked to continued high levels of DDE in their tissues (Ellis et al., 1989). Bald eagles (Haliaeetus leucocephalus) in the lower Columbia River estuary have the poorest reproductive success of any population in the Pacific Northwest, an occurrence due mainly to the levels of PCB's and DDE in these birds (Sumich, 1996).

It is evident that the organisms that suffer the greatest from such chronic exposure are those at the top of the food chain feeding in aquatic environments (Hunt \& Bischoff, 1960; Tanabe et al., 1984). This is because fish have very inefficient mixed function oxidase systems for detoxifying and excreting these contaminants, and so carry relatively high loads (Macek \& McAllister, 1970). Piscivorous organisms, such as fish-eating birds, mink, otters, cetaceans, and pinnipeds, therefore, pick up higher amounts than other animals. Many of these fish eaters also have poor detoxifying capabilities, and tend to accumulate

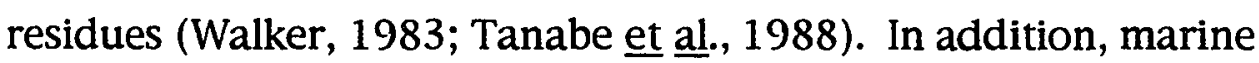
mammals and penguins have large fat stores where residues can 
accumulate to exceedingly high levels, and be released in lethal amounts if these fat reserves are mobilized for energy (Harwood $\&$ Reijnders, 1988). When all these facts are coupled with the knowledge that the oceans and lakes are the main ultimate repository for the organochlorine pollutants, it becomes evident that aquatic predators at the top of the food chain are probably more at risk than most other animal species (Tanabe, 1988).

The marine mammals are a major component of this at-risk group of animals. Whales, dolphins, seals, sea lions, the sea otter (Enhydra lutris) and the polar bear (Ursus maritimus) are major predators residing mostly at the top of the oceanic food chains. Exceptions are the baleen whales which feed further down, and the Sirenians which are herbivores (Haley, 1978). The question soon arises as to whether or not organochlorine residues are found in these animals, and if so, then at what levels are they found and what are their effects? The answer to the first question is a definite yes, with levels found to be discussed later. The answer to the last question is more complicated. Organochlorines have been implicated in the decline of many marine mammal populations, such as that of harbor seals in the Wadden Sea, harbor porpoises (Phocoena phocoena) in the Baltic Sea, Wadden Sea, and southern Puget Sound, and striped dolphins (Stenella coeruleoalba) in the Mediterranean (Otterlind, 1976; Calambokidis et al., 1978; Reijnders, 1982; Wolff, 1982; Borrell \& Aguilar, 1991). The continuing depressed state of St. Lawrence River belugas and 
of California sea otters has been attributed to chronic exposure to organochlorine contaminants (Martineau et $\underline{\text { al., }}$ 1987; Bacon et $\underline{\text { al., }}$ 1995). Direct chronic effects on individual organisms have been difficult to demonstrate, but strong correlations have been made between high levels of these pollutants and detrimental effects on marine mammals. The occurrence of metastatic carcinoma in California sea lions was correlated with higher levels of PCB's and DDT (Gulland et al., 1995). DeGuise et al. (1995a) reported a high incidence of lesions, mainly in the digestive tract and mammary glands, in the belugas of the St. Lawrence, where these animals carry high organochlorine burdens. Skull bone lesions and high levels of DDE were found in Baltic grey seals, while PCB's have been associated with skin disease in northern elephant seals (Mirounga angustirostris) (Bergman et al., 1992; Beckman \& Newman, 1993). Pathological changes in the uteri of grey seals, harbor seals, and ringed seals (Phoca hispida) of the Baltic Sea have been correlated with high levels of PCB's and DDT (Helle et al., 1976). These changes consisted of occlusions in one or both horns of the uterus and interference with reproduction. Helle et al. (1976) considered PCB's to be the primary cause of these occlusions, although Reijnders (1980) suggested that other factors, such as differences in reproductive status, may be operating.

It is at the level of the reproductive system that the chronic organochlorine loads carried by predatory marine mammals apparently have the greatest effect. Reproductive success is low 
in animals exhibiting high contaminant loads (Martineau et al., 1987; Olsson et al., 1994). Delong et al (1973) reported that premature births among California sea lions were associated with high organochlorine levels. Premature pups lived only a short time. A reproductive deficit is apparent in St. Lawrence belugas, probably due to disruptions of the system in females with high contaminant loads (Beland et al., 1992). Studies with mink, a fisheating relative of the pinnipeds, illustrate that the frequency of interrupted pregnancies increases with increased concentrations of PCB's, with pathological changes in the uterus similar to those found by Helle et al. (1976) in Baltic seals (Backlin \& Bergman, 1992; Kihlstrom et al., 1992). These studies were controlled ones in which ranch mink were fed fish contaminated with PCB's, along with a control group fed PCB-free fish. Utilizing a similar experimental design, Reijnders (1986) demonstrated a causal relationship between the level of PCB's in harbor seals and reproductive failure. Seals fed fish with higher levels of PCB's exhibited greater reproductive failure than those fed lower PCBlevel fish. This lowered success in reproduction appeared to be due to disruption in the post-ovulation phase, probably during the period around implantation (Reijnders, 1986). Reijnders hypothesized that such disruption could be the result of hormonal disturbances caused by induction of the mixed function oxidase system by the PCB's. PCB's were shown to alter steroid hormone biosynthesis in the grey seal, a finding that supports Reijnders 
view (Freeman \& Sangalang, 1977). Reproduction in marine mammals carrying high loads of DDT and DDE rather than PCB's may also be adversely affected by the same mixed function oxidase system induction and disruption of the endocrine system (DeLong et al., 1973; Subramanian et al., 1987). In addition, significant amounts of organochlorines can be transferred from an adult female to her fetus or nursing offspring (Gaskin, 1982; Subramanian et al., 1988; Bonner, 1990). With the grey seal, Addison \& Brodie (1977) calculated that $15 \%$ of the total body burden of PCB's and $30 \%$ of the total DDT and its metabolites could be transferred to a lactating pup. Values for striped dolphins were even higher, $72-98 \%$ (Tanabe et al., 1982). Although Duinker \& Hillebrand (1979) estimated that a female harbor porpoise passes $15 \%$ of her organochlorine load to her fetus, other investigators found much lower percentages in different species. In grey seals, the amount is calculated to be only $1 \%$, while in striped dolphins it is estimated to be 4-9\% (Donkin et al., 1981; Tanabe et al., 1982). It, therefore, appears that placental transfer of contaminants is not as important as transfer through lactation in many species (Subramanian et al., 1988). This overall movement of organochlorines from mother to offspring would account for the decline in contaminant concentration with age observed in sexually mature females, but not in males (Addison et al., 1973; Frank et al., 1973; Gaskin et al., 1983). In addition, it has been demonstrated that DDT and DDE are more easily 
transferred than PCB's, and that lower chlorinated biphenyls are preferentially transferred to the offspring, mainly through lactation (Addison \& Brodie, 1977; Holden, 1978; Subramanian et al., 1988). Such transfer, whether placental, lactational, or both, therefore endows the calf or pup with a contaminant load that may result in birth defects, incomplete or incorrect organ development, growth and reproductive defects, and lowered life expectancy (Calambokidis et al., 1984; Beland et al., 1992; DeGuise et al., 1994).

It has been shown that not all the different congeners of a PCB mixture have the same toxicity to animals (McKinney et al., 1976; Poland \& Glover, 1977). Specifically, non-ortho coplanar congeners are much more toxic than most of the others (Safe, 1984). Some mono-ortho coplanar congeners also exhibit high toxicity (Sawyer \& Safe, 1982). One of the major manifestations of such toxicity is immune system suppression, along with reproductive disruptions (Auerlich et al., 1985; Vos \& Luster, 1989). Immune suppression has also been demonstrated with organochlorine insecticide intake (Fournier et al., 1986). Immune responses in harbor seals were shown to be impaired by intake of organochlorines in a controlled experiment performed by de Swart et al. (1994). Such disruption of immune system functioning leaves the animal more susceptible to opportunistic infections (Crowe, 1995; DeGuise et al., 1995b). It is now believed that the massive die-off of seals in northern European waters in 
1988 was due to the phocine distemper virus (PDV) striking previously unexposed populations with suppressed immune systems, a suppression brought about by high organochlorine loads (Kennedy et al., 1988; Osterhaus \& Vedder, 1988; Brouwer et al., 1989; Dietz et al., 1989; Eis, 1989; Osterhaus \& Vedder, 1989; Hall et al., 1992). Large mortalities of bottlenose dolphins (Tursiops truncatus) along the southeastern coast of the U.S. in 1987-88 and striped dolphins in the Mediterranean in 1990 have also been considered to be due to a similar suppression and infection scenario (Geraci, 1989; Kuehl et al., 1991; Aguilar \& Borrell, 1994). The high rate of infection and disease in the St. Lawrence belugas appears to be tied in large part to the organochlorine effect on the immune system (Martineau et al., 1994; DeGuise et al., 1995b). In affecting the immune system, non-ortho coplanar PCB congeners induce atrophy of the thymus gland along with other effects (Poland \& Knutson, 1982; Davis et al., 1988; Andersson et al., 1991). This impairs T-lymphocyte maturation, and is one of the factors leading to immune deficiency (Guyton, 1986). Thymic atrophy was detected in the seals that died in the 1988 epizootic outbreak in northern Europe, indicating an effect of these toxic coplanar congeners (Kendall et al., 1992). However, seals in the Baltic Sea often exhibit a long-term chronic disease syndrome characterized by hyperadrenocorticism, but no thymic atrophy (Brandt et al., 1992). As previously mentioned, DDE-methyl sulfones have been found in considerable amounts in 
the adrenals of Baltic seals, along with PCB-methyl sulfones (Janssen et al., 1975; Haraguchi et 르., 1992). These substances are highly toxic to adrenal tissue, so DDT and PCB's may be working together through their metabolites to effect this syndrome (Lund, 1994; Olsson et al., 1994). The chronic effects of organochlorines in marine mammals, therefore, are many and varied, ranging from inducement of cancerous tumors to impaired reproductive and immune functioning (Martineau et al., 1988; Reijnders, 1994). The abilities of these animals to metabolize and excrete these substances are quite poor, and many of them live and feed in coastal areas where the input of organochlorines is continuing (Tanabe et al., 1988; Tanabe et al., 1994). It is no wonder that predatory marine mammals are considered to be highly at risk from this contamination of their environment (Tanabe, 1988; Loganathan \& Kannan, 1991).

With this in mind, it becomes imperative for the preservation and management of these animals that the extent of their organochlorine load be known. Researchers have been monitoring the amounts of DDT, its metabolites, the cyclodienes, and PCB's since the 1960's (Anas \& Wilson, 1970; Holden, 1973). The results of these investigations are given in chronological order in Tables III-XV. Values in ppm-wet weight are usually given for total PCB concentration, total concentration of DDT and its metabolites together, and DDE concentration. Values for dieldrin, hexachlorobenzene, and individual PCB congeners are sometimes 
given (Calambokidis et al., 1984; Luckas et al., 1990; Kleivane et al., 1995). For the sake of simplicity, only the values for total DDT $=\mathrm{DDT}+\mathrm{DDE}+\mathrm{DDD}, \mathrm{p}, \mathrm{p}-\mathrm{DDE}$, and total PCB's are listed in these tables. It can be seen from this data that levels of organochlorines have generally declined since the 1970 's, but in some populations levels have remained relatively stable, and that they are high in animals from coastal and semi-enclosed seas (Borrell \& Aguilar, 1991). Many populations are still exhibiting levels in blubber tissue that have been associated with severe chronic effects. For example, DeLong et al., (1973) found that abortion in California sea lion females occurred with high frequency in animals carrying mean organochlorine loads of $110 \mathrm{ppm}$ or greater. The St. Lawrence belugas show numerous dysfunctions with levels of 5.7-576 ppm (Martineau et al., 1987). The occurrence of continuing elevated levels in some populations is not surprising considering the following facts; 1) marine mammals are long-lived and clear xenobiotics very slowly, 2 ) organochlorines are still being used in certain areas of the world, and 3) these contaminants are transported globally and ultimately deposited mostly in the oceans (Loganathan \& Kannan, 1991).

Along with monitoring the loads in these animals, residue determinations can be used to trace the age and reproductive status of individuals and discriminate between populations (Aguilar \& Borrell, 1988; Subramanian et al., 1988). The former can be done due to the variations in levels in females as a result 
of reproductive activities, whereas males tend to accumulate residues at a constant rate over a lifetime (Wagemann \& Muir, 1984). In the latter, use is made of residue levels to delineate population boundaries, and assign individuals to certain populations. Although variations in residue levels are usually large among individuals, ratios which do not vary as much can be used effectively (Aguilar, 1987). Examples of such ratios are DDE/total DDT, total DDT/PCB, and PCB/p,p-DDE (Calambokidis \& Barlow, 1991). The ratios of p,p-DDT/p,p-DDE and DDE/total DDT are also used to indicate the possibility of continued input of DDT into a certain ecosystem (Aguilar, 1984; Bacon et al., 1992). Since DDE is the primary stored metabolite in marine mammals, an increasing level of DDE relative to DDT would indicate "old" pollution, with little or no input of the parent compound in recent years (Law et al., 1989). The major value, however, of residue monitoring in predatory marine mammals lies in the fact that these animals are excellent indicator species of the health of the marine environment. They are in essence the "canaries" of the oceans (Nicklin, 1995). If their organochlorine loads are low or have declined, then their environment is healthy or becoming so, at least in terms of these contaminants and perhaps others. If not, then probably the entire marine environment is in danger.

It is, therefore, absolutely necessary to monitor the levels of organochlorines in marine mammals. This process involves the extraction of the contaminants from blubber or some other tissue, 
the cleanup of extracts by removing the lipid coextractives, and the detection of the presence and determination of the levels of the extracted substances (Wheeler \& Thompson, 1981). The general multiresidue method for high fat samples extracts the pollutants into petroleum ether, partially removes coextracted lipids by partitioning between acetonitrile and petroleum ether, and completes the cleanup by passing the partitioned extract through a column of activated Florisil (McMahon \& Hardin, 1994). Other investigators have substituted hexane for petroleum ether, used dimethyl sulfoxide or dimethylformimide in place of acetonitrile, and utilized other materials, such as alumina, in place of Florisil (Haenni et al., 1962; de Faubert Maunder et al., 1964; Reichel \& Addy, 1968; Reynolds, 1969; Quintanilla-Lopez et al., 1992). Schantz et al. (1993) have described a method specifically for marine mammal blubber involving extraction into methylene chloride and cleanup with size-exclusion chromatography on aminopropylsilane. Most other researchers monitor marine mammals using the general multiresidue method with modifications (Calambokidis et al., 1984; Muir et al., 1988a; Bacon et al., 1992; Roos et al., 1992). Detection of residues is perfomed using gas chromatography (GC) and an electron-capture detector (ECD), with concentrations determined from peak area or height (Fishbein, 1972; Fishbein, 1974; Donkin et al., 1981; Sherma \& Zweig, 1983; Sherma \& Zweig, 1985). Thin-layer chromatography (TLC) has also been used for both qualitative and quantitative 
determination (Abbott \& Thompson, 1965; Bishara et al., 1972; Sherma, 1974; Kirchner, 1978; Mendoza, 1981).

High performance liquid chromatography (HPLC) has been little used for the detection of organochlorine residues. The volatile nature of the residue extract and the lack of sensitive ultraviolet (UV) wavelength detectors early on, made GC the method of choice (Horgan, 1974; Sherma, 1981). Although some workers demonstrated the feasibility of HPLC, it was mostly used in sample cleanup before determination by GC (Eisenbeiss \& Sieper, 1973; Demeter \& Heyndrickx, 1979; Petrick et al., 1988). The potential of both adsorption and reverse-phase HPLC was demonstrated by Aitzetmuller (1975) and Seiber (1974), respectively, but use usually occurred only when the HPLC was connected to a detector other than UV (Willmott \& Dolphin, 1974; Dolan \& Seiber, 1977). With the development of the variablewavelength UV detector, it became possible to use HPLC for the detection and quantification of organochlorine residues (Hackwell \& Self, 1978). Brinkman et al. (1976a) demonstrated that organochlorine insecticides and PCB's could be detected at $205 \mathrm{~nm}$ utilizing a Lichrosorb SI 60, 5 um column (E. Merck, Darmstadt, Ger.) and hexane as a mobile phase. Individual PCB's could also be separated and detected (Brinkman et al., 1976b). Other workers also reported results using HPLC to separate and detect these chlorinated pollutants (Lawrence \& Turton, 1978). However, some of the insecticides such as aldrin, dieldrin, lindane, and heptachlor 
exhibit little or no UV absorption; HPLC with a UV detector would be of little use for detecting these residues (Osselton \& Snelling, 1986). PCB's, as well as the DDT group of insecticides, absorb UV well enough at shorter wavelengths to permit the use of HPLC (Eisenbeiss \& Sieper, 1973; MacNeil et al., 1976). Derivatization of residues to a more UV-absorbing product could also be done (Seidl \& Ballschmiter, 1979). The limit of detection of GC with an ECD is lower than that of HPLC with a UV detector. This and the poor UV absorbance of the cyclodienes have continued to make GC the recommended method of organochlorine residue determination (Horwitz, 1980).

One of the major difficulties in this determination, whether using GC, HPLC, or TLC, is that of separating the PCB's from the insecticides, especially those of the DDT group. This occurs because the PCB's have similar retention times to the insecticides (Sherma, 1981). Several methods have been reported to effect separation. Fehringer \& Westfall (1971) used two-dimensional TLC, while Armour \& Burke (1970) utilized liquid-solid fractionation. One of the most widely used methods is chemical derivatization, in which DDT and DDD are dehydrochlorinated to DDE and DDMU, respectively, and these olefins are oxidized with chromium trioxide to dichlorobenzophenone (DCBP) (Miles, 1972; Young \& Burke, 1972). DCBP exhibits a retention time different from PCB's in both GC and HPLC, and a different migration distance in TLC (Mulhern et al., 1971; Collins et al., 1972). These 
authors demonstrated the use of this technique in the determination of PCB's and DDE in wildlife samples. As stated previously, DDE is the most commonly found organochlorine in wildlife along with PCB's, so this chromium trioxide oxidation procedure prior to GC or TLC permits the detection and determination of levels of the most commonly occurring organochlorines in environmental samples. Although Szelewski et al. (1979) have shown some loss of PCB homologues during the chromium trioxide oxidation process, it can still be used in gaining an approximation of the total PCB and DDE levels in organisms. Since PCB's and DDE absorb UV light well at shorter wavelengths, HPLC could be used to estimate levels of these substances in the environment, especially at the concentrations that occur in many higher trophic level species. Chiosi et al. (1982) did exactly this to determine the amounts of PCB's and DDE in snails and tuna from the Mediterranean Sea. These authors were able to skip the Florisil cleanup step by performing the oxidation for 15 hours at $80^{\circ} \mathrm{C}$, rather than for the usual 20 minutes at $95^{\circ} \mathrm{C}$ (Collins et al., 1972; Miles, 1972). The process could be accelerated with the inclusion of the Florisil step permitting the analysis of more samples. The potential for the use of HPLC as a screening technique for the presence and approximate concentration of PCB's and DDE in the lipid tissue of higher animals is, therefore, obvious. Marine mammals, in particular, could be analyzed for these contaminants using this process. Blubber samples from 
stranded animals could be subjected to extraction and partition cleanup with one of the reported methods. The hexane or petroleum ether eluate of the Florisil column could then be retained, as this contains PCB's and DDE, along with other organochlorines which exhibit little or no UV absorbance (Reynolds, 1969; Calambokidis et al., 1984; Osselton \& Snelling, 1986). This eluate could then be subjected to chromium trioxide oxidation, followed by injection into an HPLC system. PCB's and DDE would be separated and semiquantified. A relatively fast and straight forward method would, thereby, be available for approximating the loads of these substances in marine mammals; the indicator species, as well as the species most at risk from organochlorine pollution of the marine environment. 
TABLE III

Organochlorine Concentrations (ppm - wet wt.) Reported in the Blubber of the Harbor Seal (Phoca vitulina). Mean Values; Ranges in Parentheses.

\begin{tabular}{|c|c|c|c|c|c|}
\hline Year & Location & tDDT & $\mathrm{p}, \mathrm{p}-\mathrm{DDE}$ & $\underline{\text { PCB's }}$ & Source \\
\hline 1964 & $\begin{array}{l}\text { Wadden } \\
\text { Sea }\end{array}$ & $\begin{array}{c}16.4 \\
(9.6-27.4)\end{array}$ & $\begin{array}{c}7.7 \\
(5.4-14.0\end{array}$ & \multicolumn{2}{|c|}{$\begin{array}{r}\text { Koeman \& } \\
\text { van Genderen, } \\
1966\end{array}$} \\
\hline $\begin{array}{c}1965 \\
-68\end{array}$ & $\begin{array}{c}\text { Baltic } \\
\text { Sea }\end{array}$ & $\begin{array}{c}130 \\
(110-150)\end{array}$ & & $\begin{array}{c}30 \\
(18-43)\end{array}$ & $\begin{array}{l}\text { Jensen } \\
\frac{\text { et }}{1969} .\end{array}$ \\
\hline $\begin{array}{c}1969 \\
-70\end{array}$ & $\begin{array}{l}\text { central } \\
\text { Calif. }\end{array}$ & $(18 \& 158)$ & (15\&142 & & $\begin{array}{l}\text { Shaw, } \\
1971\end{array}$ \\
\hline 1971 & $\begin{array}{l}\text { cent. Calif. } \\
\text { north. Ore. } \\
\text { Puget Sound } \\
\text { Alaska }\end{array}$ & $\begin{array}{r}610.7 \\
62.5 \quad(2 \\
862.7 \\
11.3\end{array}$ & $\begin{array}{l}(1-2350) \text { to } \\
27-110) \\
9-1620) \\
(6-28)\end{array}$ & $\begin{array}{c}\text { otal DDT \& PCE } \\
"\end{array}$ & $\begin{array}{l}\text { Anas, } \\
1974\end{array}$ \\
\hline 1971 & $\begin{array}{l}\text { Wadden } \\
\text { Sea }\end{array}$ & $\begin{array}{c}9.5 \\
(6.5-17.3)\end{array}$ & $\begin{array}{c}5.2 \\
(0.3-12)\end{array}$ & $\begin{array}{c}1009 \\
(47-2530)\end{array}$ & $\begin{array}{l}\text { Koeman } \\
\frac{\text { et }}{1972} \frac{\mathrm{al}}{},\end{array}$ \\
\hline 1971 & $\begin{array}{l}\text { Maine } \\
\text { Canada } \\
\text {-S.E. }\end{array}$ & $\begin{array}{c}65.4 \\
(25.3-139) \\
38.4 \\
(8.6-52)\end{array}$ & $\begin{array}{c}33.6 \\
(14.9-54) \\
19.7 \\
(4.9-33)\end{array}$ & $\begin{array}{c}92.5 \\
(27.9-240) \\
52.3 \\
(43-63)\end{array}$ & $\begin{array}{l}\text { Gaskin } \\
\frac{\text { et }}{1973} .\end{array}$ \\
\hline 1972 & $\begin{array}{l}\text { Scotland } \\
\text {-Shet.Is. } \\
\text { Scotland } \\
\text {-Clyde R. } \\
\text { England } \\
\text {-the Wash }\end{array}$ & $\begin{array}{c}2.6 \\
(1.6-3.5) \\
25.2 \\
(19-31) \\
6.5 \\
(3.5-9.7)\end{array}$ & & $\begin{array}{c}4.0 \\
(2.0-6.0) \\
75.0 \\
(58-99) \\
15.0 \\
(7.0-24)\end{array}$ & $\begin{array}{c}\text { Holden, } \\
1972\end{array}$ \\
\hline
\end{tabular}


54

\begin{tabular}{|c|c|c|c|c|c|}
\hline 1972 & $\begin{array}{l}\text { Puget Sound } \\
\text {-south } \\
\text { Puget Sound } \\
\text {-north } \\
\text { Washington } \\
\text {-coast }\end{array}$ & $\begin{array}{c}9.5 \\
(0.3-29.6) \\
6.6 \\
(2.1-16.5) \\
5.34 \\
(0.9-14.4)\end{array}$ & & $\begin{array}{c}145 \\
(16-374) \\
44 \\
(12.8-78) \\
47.8 \\
(13.8-136)\end{array}$ & $\begin{array}{c}\text { Arndt, } \\
1973\end{array}$ \\
\hline $\begin{array}{c}1975 \\
-76\end{array}$ & $\begin{array}{l}\text { Denmark } \\
\text { Wadden } \\
\text { Sea }\end{array}$ & $\begin{array}{c}17.0 \\
(4.0-47) \\
30.0 \\
(3.3-130)\end{array}$ & $\begin{array}{l}11.0 \\
16.0\end{array}$ & $\begin{array}{c}110 \mathrm{Re} \\
(23-340) \\
130 \\
(5.0-680)\end{array}$ & $\begin{array}{c}\text { ijnders, } \\
1980\end{array}$ \\
\hline $\begin{array}{c}1975 \\
-76\end{array}$ & $\begin{array}{c}\text { cent. Calif. } \\
\text {-coast } \\
\text { San Fran. } \\
\text { Bay }\end{array}$ & $\begin{array}{c}19.3 \\
(10-27) \\
38.4 \\
(4.8-130)\end{array}$ & $\begin{array}{c}19.3 \\
(10-27) \\
37.2 \\
(4.6-130)\end{array}$ & $\begin{array}{c}36.9 \\
(3.5-110) \\
136.6 \\
(11-410)\end{array}$ & $\begin{array}{c}\text { Rise- } \\
\text { brough, } \\
1978\end{array}$ \\
\hline
\end{tabular}

$\begin{array}{cccccc}1975 & \text { Wadden } & 7.28 & 3.40 & 131.5 & \text { Drescher } \\ & \text { Sea } & (2.2-27) & (1.0-17) & (31-564) & \frac{\mathrm{et}}{\mathrm{al}} \text {., } \\ & & & & 1977 \\ 1976 & \text { Puget Sound } & & 10.0 & 110 & \text { Calam- } \\ -77 & \text {-south } & (0.9-42) & (15-620) & \text { bokidis } \\ & \text { Puget Sound } & 3.2 & 11 & \text { et } \frac{\text { al., }}{1984} \\ & \text {-north } & (0.8-10) & (3.7-29) & 198 \\ \text { Washington } & & 6.7 & 14 & \\ \text {-coast } & & (0.8-22) & (1.9-63) & \end{array}$

1977 Norway $2.1 \quad 16 \quad$ ofstad \& (1.2-4.6) lipid wt. (13-23) Martinsen, 1983

1979 Wadden $\quad 10.9 \quad 7.38 \quad 189$ Duinker Sea $\quad(0.5-25.4) \quad(0.5-20.3) \quad(22-576) \quad$ et al.,

1984 Japan

2.4 Tanabe (2.0-3.0) et al., 1988 


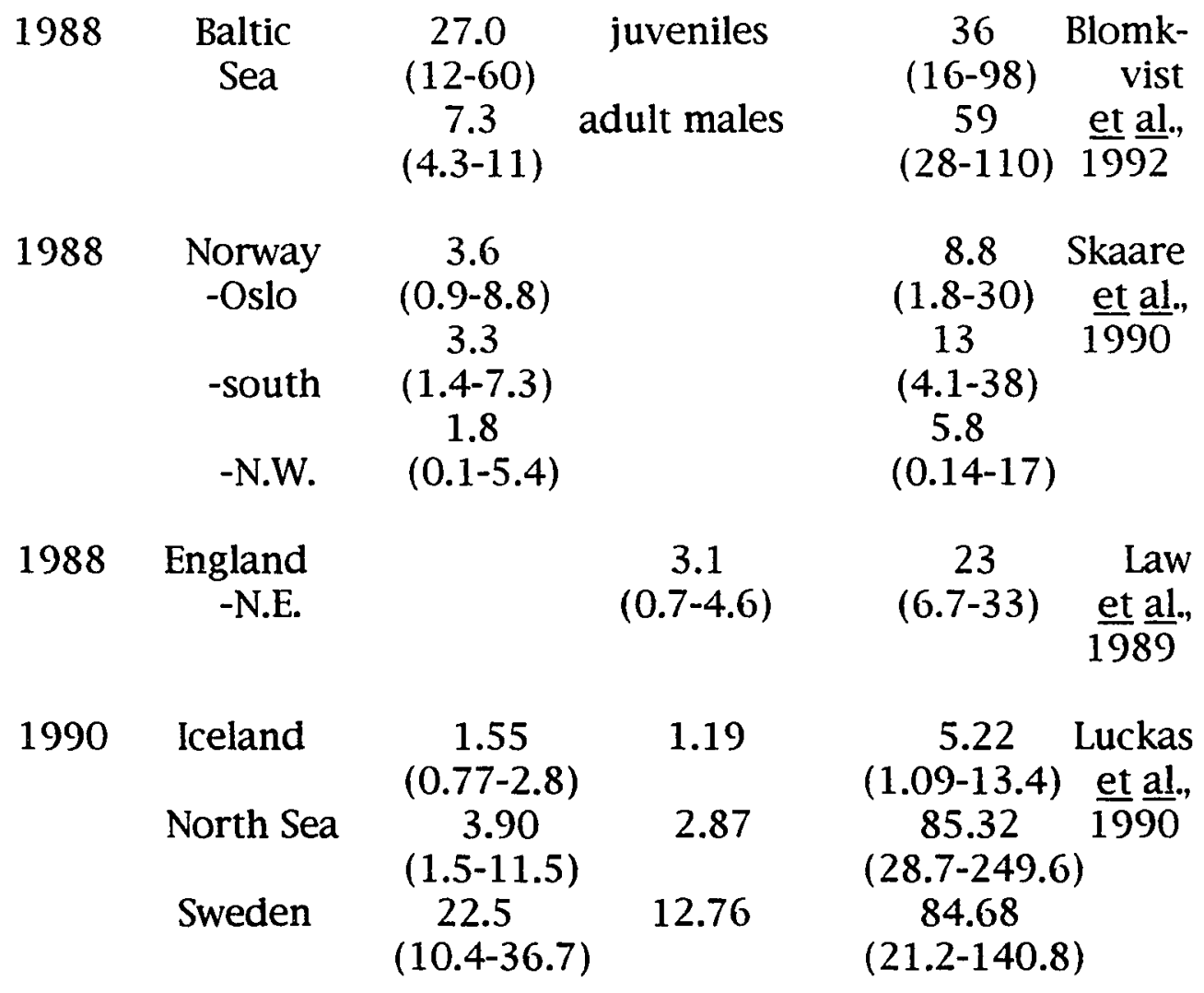




\section{TABLE IV}

Organochlorine Concentrations (ppm - wet wt.) Reported in the Blubber of the Ringed Seal (Phoca hispida).

Mean Values; Ranges in Parentheses.

\begin{tabular}{|c|c|c|c|c|c|}
\hline Year & Location & tDDT & $\mathrm{p}, \mathrm{p}$-DDE & PCB'S & Source \\
\hline $\begin{array}{c}1965 \\
-68\end{array}$ & $\begin{array}{l}\text { Baltic } \\
\text { Sea }\end{array}$ & $\begin{array}{c}120 \\
(110-130)\end{array}$ & & $\begin{array}{c}13 \\
(9.7-16)\end{array}$ & $\begin{array}{l}\text { Jensen } \\
\frac{\text { et }}{1969} \frac{\text { al., }}{}\end{array}$ \\
\hline 1972 & $\begin{array}{l}\text { Arctic } \\
\text { Baltic Sea }\end{array}$ & $\begin{array}{c}2.5 \\
(1.0-3.9) \\
23.8\end{array}$ & & $\begin{array}{c}2.0 \\
(1.0-4.0) \\
22.0\end{array}$ & $\begin{array}{c}\text { Holden, } \\
1972\end{array}$ \\
\hline 1972 & Greenland & & $\begin{array}{c}0.15 \\
(0.02-0.26)\end{array}$ & $\begin{array}{c}0.9 \\
(0.6-1.3)\end{array}$ & $\begin{array}{l}\text { Clausen } \\
\frac{\text { et }}{1974} \frac{\text { al. }}{19}\end{array}$ \\
\hline 1972 & $\begin{array}{l}\text { Arctic } \\
\text {-female } \\
\text { Arctic } \\
\text {-male }\end{array}$ & $\begin{array}{r}0.55 \\
\pm 0.21 \\
1.10 \\
\pm 0.51\end{array}$ & $\begin{array}{c}0.28 \\
\pm 0.095 \\
0.63 \\
\pm 0.33\end{array}$ & $\begin{array}{r}1.83 \\
\pm 0.82 \\
3.69 \\
\pm 1.34\end{array}$ & $\begin{array}{r}\text { Addison } \\
\text { \& Zinck, } \\
1986\end{array}$ \\
\hline 1972 & $\begin{array}{l}\text { Arctic } \\
\text {-female }\end{array}$ & $\begin{array}{r}0.809 \\
+0.370\end{array}$ & $\begin{array}{r}0.324 \\
+0.019\end{array}$ & $\begin{array}{r}0.639 \\
+0.249\end{array}$ & $\begin{array}{l}\text { Muir } \\
\text { et al., }\end{array}$ \\
\hline $\begin{array}{c}1975 \\
-76\end{array}$ & $\begin{array}{l}\text { Arctic } \\
\text {-female }\end{array}$ & $\begin{array}{c}0.630 \\
\pm 0.166\end{array}$ & $\begin{array}{r}0.321 \\
\pm 0.008\end{array}$ & $\begin{array}{r}0.600 \\
\pm 0.099\end{array}$ & $1988 \mathrm{a}$ \\
\hline 1975 & $\begin{array}{l}\text { Arctic } \\
\text { Hudson's Bay }\end{array}$ & & $\begin{array}{c}0.195 \\
(0.003-1.93) \\
0.821\end{array}$ & $\begin{array}{c}0.348 \\
(0.003-1.35) \\
1.01\end{array}$ & $\begin{array}{c}\text { Bowes \& } \\
\text { Jonkel, } \\
1975\end{array}$ \\
\hline 1981 & $\begin{array}{l}\text { Arctic } \\
\text {-female } \\
\text { Arctic } \\
\text {-male }\end{array}$ & $\begin{array}{r}0.33 \\
\pm 0.14 \\
0.78 \\
\pm 0.56\end{array}$ & $\begin{array}{r}0.14 \\
\pm 0.10 \\
0.39 \\
+0.32\end{array}$ & $\begin{array}{r}0.58 \\
+0.25 \\
1.28 \\
+0.75\end{array}$ & $\begin{array}{l}\text { Addison } \\
\& \text { Zinck, } \\
1986\end{array}$ \\
\hline
\end{tabular}




\begin{tabular}{|c|c|c|c|c|c|}
\hline 1983 & $\begin{array}{l}\text { Arctic } \\
\text {-male }\end{array}$ & $\begin{array}{r}1.33 \\
\pm 1.50\end{array}$ & $\begin{array}{c}0.88 \\
+0.195\end{array}$ & $\begin{array}{c}0.79 \\
+0.879\end{array}$ & $\begin{array}{l}\text { Muir } \\
\text { et al., }\end{array}$ \\
\hline 1984 & $\begin{array}{l}\text { Arctic } \\
\text {-male }\end{array}$ & $\begin{array}{c}0.714 \\
+0.40\end{array}$ & $\begin{array}{c}0.592 \\
\pm 0.29\end{array}$ & $\begin{array}{r}0.568 \\
+0.287\end{array}$ & $1988 a$ \\
\hline 1986 & Spitzbergen & & $\begin{array}{c}1.25 \\
(0.6-2.3)\end{array}$ & $\begin{array}{c}0.837 \\
(0.42-1.46)\end{array}$ & $\begin{array}{l}\text { Oehme } \\
\frac{\text { et }}{1988} \text {, }\end{array}$ \\
\hline 1988 & $\begin{array}{c}\text { Baltic } \\
\text { Sea }\end{array}$ & $\begin{array}{c}13.0 \\
(4.4-46) \\
230.0 \\
(150-820)\end{array}$ & $\begin{array}{l}\text { juveniles } \\
\text { adult males }\end{array}$ & $\begin{array}{c}17.0 \\
(7.7-44) \\
210 \\
(120-770)\end{array}$ & $\begin{array}{r}\text { Blomk- } \\
\text { vist } \\
\frac{\text { et }}{1992 .}\end{array}$ \\
\hline
\end{tabular}




\section{TABLE V}

Organochlorine Concentrations (ppm - wet wt.) Reported in the Blubber of the Grey Seal (Halichoerus grypus).

Mean Values; Ranges in Parentheses.

\begin{tabular}{|c|c|c|c|c|c|}
\hline Year & Location & ĐDT & p,p-DDE & PCB's & Source \\
\hline $\begin{array}{c}1965 \\
-68\end{array}$ & $\begin{array}{c}\text { Baltic } \\
\text { Sea }\end{array}$ & $\begin{array}{c}170 \\
(97-310)\end{array}$ & & $\begin{array}{c}30 \\
(16-56)\end{array}$ & $\begin{array}{l}\text { Jensen } \\
\frac{\text { et }}{1969} \text { al. }\end{array}$ \\
\hline 1967 & $\begin{array}{l}\text { Scotland } \\
\text {-east } \\
\text { Scotland } \\
\text {-N.W. } \\
\text { Scotland } \\
\text {-N.W. } \\
\text { Canada } \\
\text {-N.E. } \\
\text { Canada } \\
\text {-S.E. }\end{array}$ & $\begin{array}{c}14.5 \\
(2.8-34) \\
7.6 \\
(3.1-15.5) \\
5.1 \\
(2.2-8.3) \\
1.7 \\
(0.83-2.6) \\
12.2 \\
(3.7-35)\end{array}$ & $\begin{array}{c}5.5 \\
(1.0-11.1) \\
3.4 \\
(1.2-7.0) \\
2.5 \\
(1.0-4.0) \\
1.2 \\
(0.67-1.8) \\
5.9 \\
(1.2-13.3)\end{array}$ & $\begin{array}{l}\text { adults } \\
\text { pups }\end{array}$ & $\begin{array}{c}\text { Holden \& } \\
\text { Marsden, } \\
1967\end{array}$ \\
\hline 1971 & $\begin{array}{l}\text { England } \\
\text {-east } \\
\text { England } \\
\text {-N.W. }\end{array}$ & $\begin{array}{r}15.53 \\
+8.31 \\
8.90 \\
\pm 5.08\end{array}$ & & $\begin{array}{c}152 \\
\pm 164.2 \\
11.1 \\
\pm 6.9\end{array}$ & $\begin{array}{c}\text { Hepple- } \\
\text { ston, } \\
1973\end{array}$ \\
\hline 1972 & $\begin{array}{l}\text { Scotland } \\
\text {-Orkneys } \\
\text { Scotland } \\
\text {-Aberdeen } \\
\text { England } \\
\text {-Farne Is. } \\
\text { England } \\
\text {-Scroby } \\
\text { Wales }\end{array}$ & $\begin{array}{c}13.0 \\
(2.9-25.0) \\
20.1 \\
(8.4-36.0) \\
13.0 \\
(6.4-19.0) \\
39.7 \\
(27.0-52.0) \\
17.5 \\
(14.0-21.0)\end{array}$ & & $\begin{array}{c}18.0 \\
(3.0-30) \\
38.0 \\
(12.0-88) \\
40.0 \\
(25.0-50) \\
123 \\
(100-146) \\
212 \\
(200-235)\end{array}$ & $\begin{array}{l}\text { Holden, } \\
1972 \\
\text { 6) } \\
\text { 5) }\end{array}$ \\
\hline
\end{tabular}


59

\begin{tabular}{|c|c|c|c|c|c|}
\hline 1977 & Norway & $\begin{array}{c}2.8 \\
(0.6-8.2)\end{array}$ & $\begin{array}{c}\text { ppm- } \\
\text { lipid wt. }\end{array}$ & $\begin{array}{c}6.6 \\
(1.9-15)\end{array}$ & $\begin{array}{c}\text { Ofstad \& } \\
\text { Martin- } \\
\text { sen, } \\
1983\end{array}$ \\
\hline 1988 & $\begin{array}{l}\text { England } \\
\text {-N.E. }\end{array}$ & & $\begin{array}{c}2.6 \\
(0.58-3.6)\end{array}$ & $\begin{array}{c}18.0 \\
(5.7-28)\end{array}$ & $\begin{array}{l}\text { Law } \\
\text { et } \frac{\text { al. }}{198}\end{array}$ \\
\hline 1988 & $\begin{array}{l}\text { Baltic } \\
\text { Sea }\end{array}$ & $\begin{array}{c}35.0 \\
(19-91) \\
36.0 \\
(11-100) \\
84 \\
(13-180)\end{array}$ & $\begin{array}{l}\text { juveniles } \\
\text { adult males } \\
\text { adult females }\end{array}$ & $\begin{array}{c}77.0 \\
(32-110) \\
103 \\
(78-180) \\
230 \\
(57-770)\end{array}$ & $\begin{array}{l}\text { Blomk- } \\
\text { vist } \\
\frac{\mathrm{et}}{19} \frac{\mathrm{al}}{92}\end{array}$ \\
\hline
\end{tabular}


TABLE VI

Organochlorine Concentrations (ppm - wet wt.) Reported in the Blubber of Other Seals.

Mean Values; Ranges in Parentheses.

Year Location

$\underline{\mathrm{DDT}}$

p,p-DDE

$\underline{\text { PCB's }}$ Source

Harp Seal (Phoca groenlandicus)

1971 Canada-

St. Law. Gulf

9.35

$(3.1-22.6)$

1971 CanadaSt. Law. Gulf

1973 Canada-

St. Law. Gulf $\quad(1.2-3.0)$

4.02

(1.6-9.8)

1.98

1.34

1973 Canada-

St. Law. Gulf
8.15 Addison (2.0-22.0) et al.,

Northern Fur Seal (Callorhinus ursinus)

1969 Alaska

16.1

$(0.67-48.0)$

1.05

$(0.6-2.1)$

1.16

$(0.6-2.0)$

pups

3.23 Rosewell (0.5-13.3) et al., $2.26 \quad 1979$ (1.2-6.2)

1.08 Jones et al., 1976

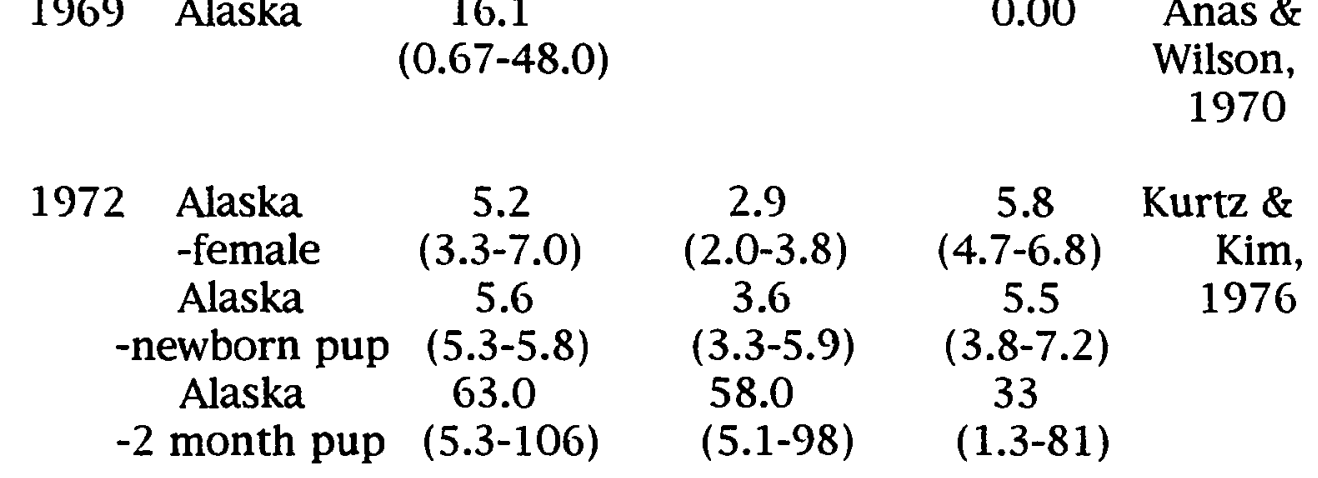


1980 Alaska

$$
\begin{array}{ccc}
7.52 & 2.49 & \text { Calam- } \\
(2.69-12.5) & (1.5-4.0) & \text { bokidis } \\
& & \& \\
& & \text { Peard, } \\
& & 1985
\end{array}
$$

Northern Elephant Seal (Mirounga angustirostris)

1983 Calif.

-84 -south
7.64

$(2.76-11.0)$
1.34 Schafer

(0.26-4.04) et al., 
TABLE VII

Organochlorine Concentrations (ppm - wet wt.) Reported in the Blubber of the California Sea Lion

(Zalophus californianus).

Mean Values; Ranges in Parentheses.

\begin{tabular}{|c|c|c|c|c|}
\hline Year & Location & tDDT & $\mathrm{p}, \mathrm{p}-\mathrm{DDE}$ & $\underline{\text { Source }}$ \\
\hline 1970 & $\begin{array}{c}\text { central } \\
\text { Calif. }\end{array}$ & $\begin{array}{c}911 \pm 582 \\
(41-2678)\end{array}$ & & $\begin{array}{c}\text { Le Boeuf \& } \\
\text { Bonnell, } \\
1971\end{array}$ \\
\hline 1970 & $\begin{array}{c}\text { central } \\
\text { Calif. }\end{array}$ & $\begin{array}{c}824.4 \pm 167.8 \\
(626-1039) \\
103.2 \pm 69.7 \\
(51-203)\end{array}$ & $\begin{array}{l}\text { premature } \\
\text { females } \\
\text { full-term } \\
\text { females }\end{array}$ & $\begin{array}{c}112.4 \pm 24.4 \text { Delong } \\
\begin{array}{c}(85-145) \\
17.1 \pm 6.1\end{array} \\
(12-25)\end{array}$ \\
\hline $\begin{array}{l}1970 \\
1971 \\
1971 \\
1973\end{array}$ & $\begin{array}{l}\text { central } \\
\text { Oregon }\end{array}$ & $\begin{array}{c}\text { sick } \\
\text { sick } \\
\text { healthy } \\
\text { healthy }\end{array}$ & $\begin{array}{l}358 \pm 213 \\
475 \pm 311 \\
253 \pm 116 \\
342 \pm 234\end{array}$ & $\begin{array}{l}24.2 \pm 11.5 \text { Buhler } \\
28.5 \pm 2.10 \text { et al., } \\
34.1 \pm 20.8 \text { 1975 } \\
21.2 \pm 2.10\end{array}$ \\
\hline 1972 & $\begin{array}{c}\text { central } \\
\text { Calif. }\end{array}$ & $\begin{array}{c}a 651 \\
(365-974) \\
b 87.6 \\
(18.5-351)\end{array}$ & $\begin{array}{c}629.8 \\
(350-939) \\
83.0 \\
(16.3-342)\end{array}$ & 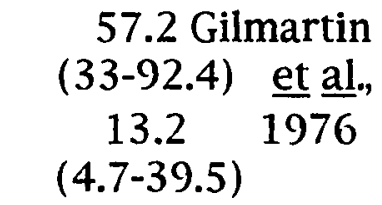 \\
\hline
\end{tabular}

a) premature pups b) full-term pups

1988 Calif.

0.16

5.0

$-92 \quad-$ south

$(0.07-0.35) \quad(2.5-10)$

Lieberg-Clark

et al.,

1995 


\section{CEIACEANNS}

TABLE VIII

Organochlorine Concentrations (ppm - wet wt.) Reported in the Blubber of the Killer Whale (Orcinus orca).

Mean Values; Ranges in Parentheses.

\begin{tabular}{|c|c|c|c|c|c|}
\hline Year & Location & tDDT & $\mathrm{p}, \mathrm{p}-\mathrm{DDE}$ & PCB's & Source \\
\hline $\begin{array}{c}1976 \\
-89\end{array}$ & $\begin{array}{c}\text { Washington } \\
\& \\
\text { Canada } \\
\text {-S.W. }\end{array}$ & $\begin{array}{c}262 \\
(117-514) \\
89.0 \\
(66-112)\end{array}$ & $\begin{array}{l}\text { transient } \\
\text { resident }\end{array}$ & $\begin{array}{c}84.0 \\
(41-140) \\
71.0 \\
(70-71)\end{array}$ & $\begin{array}{l}\text { Calam- } \\
\text { bokidis } \\
\frac{\text { et }}{1990} \frac{\text { al., }}{}\end{array}$ \\
\hline 1980 & Australia & 28.4 & & & $\begin{array}{l}\text { Kemper } \\
\frac{\text { et al., }}{1994}\end{array}$ \\
\hline $\begin{array}{r}1987 \\
-89\end{array}$ & $\begin{array}{l}\text { Canada } \\
-S . W .\end{array}$ & $\begin{array}{c}50.0 \\
(8.4-148)\end{array}$ & & $\begin{array}{c}31.0 \\
(8.5-84.4)\end{array}$ & $\begin{array}{l}\text { Muir } \\
\text { et al., } \\
1991\end{array}$ \\
\hline
\end{tabular}


TABLE IX

Organochlorine Concentrations (ppm - wet wt.) Reported in the Blubber of the Bottlenose Dolphin

(Tursiops truncatus).

Mean Values; Ranges in Parentheses.

\begin{tabular}{|c|c|c|c|c|}
\hline Year & Location & $\underline{\mathrm{DDT}}$ & $\mathrm{p}, \mathrm{p}-\mathrm{DDE}$ & Source \\
\hline 1976 & $\begin{array}{l}\text { Calif. } \\
\text {-south }\end{array}$ & $\begin{array}{c}2250 \\
(1800 \& 2700)\end{array}$ & $\begin{array}{c}2050 \\
1600 \& 2500)\end{array}$ & $\begin{array}{cc}435 & \text { O'Shea } \\
(420 \& 450) & \text { et al., } \\
1980\end{array}$ \\
\hline $\begin{array}{r}1976 \\
-87\end{array}$ & $\begin{array}{c}\text { S. Africa } \\
\text {-west }\end{array}$ & $\begin{array}{c}4.99 \\
(0.17-12.3)\end{array}$ & & $\begin{array}{c}3.55 \text { de Kock } \\
(0.16-8.29) \\
\frac{\text { et }}{1994},\end{array}$ \\
\hline $\begin{array}{c}1980 \\
-84\end{array}$ & $\begin{array}{l}\text { Calif. } \\
\text {-south }\end{array}$ & $\begin{array}{c}929 \\
(126-1270)\end{array}$ & & $\begin{array}{cc}53.04 & \text { Schafer } \\
(19.7-128) & \text { et al., } \\
1984\end{array}$ \\
\hline $\begin{array}{c}1980 \\
-87\end{array}$ & $\begin{array}{l}\text { S. Africa } \\
\text {-east }\end{array}$ & $\begin{array}{c}12.84 \\
(0.0-85.7)\end{array}$ & & $\begin{array}{l}11.17 \text { Cockcroft } \\
(0.31-67.2) \quad \text { et al., }\end{array}$ \\
\hline $\begin{array}{c}1987 \\
-88\end{array}$ & $\begin{array}{l}\text { U.S. } \\
\text {-S.E. }\end{array}$ & & $\begin{array}{r}39.50 \\
\pm 44.70\end{array}$ & $\begin{array}{c}1.82 \\
\pm 14.20\end{array}$ \\
\hline
\end{tabular}


TABLE $X$

Organochlorine Concentrations (ppm - wet wt.) Reported in the Blubber of the Common Dolphin (Delphinus delphis). Mean Values; Ranges in Parentheses.

\begin{tabular}{|c|c|c|c|c|}
\hline Year & Location & tDDT & $\mathrm{p}, \mathrm{p}-\mathrm{DDE}$ & Source \\
\hline 1966 & England & & 1.28 & $\begin{array}{l}\text { Robinson } \\
\qquad \frac{\text { et }}{1967} \frac{\text { al., }}{67}\end{array}$ \\
\hline 1972 & Rhode Is. & 71.0 & 38.0 & $\begin{array}{l}\text { Taruski } \\
\text { et al., } \\
1975\end{array}$ \\
\hline $\begin{array}{c}1968 \\
-76\end{array}$ & $\begin{array}{l}\text { Calif. } \\
\text {-south } \\
\text { Japan }\end{array}$ & $\begin{array}{c}993.8 \\
(450-1800)\end{array}$ & $\begin{array}{c}868.5 \\
(360-1700) \\
(0.54 \& 8.2)\end{array}$ & $\begin{array}{cc}139.5 & \text { O'Shea } \\
(80-300) & \text { et al., } \\
(2.4 \& 6.4) & 1980\end{array}$ \\
\hline $\begin{array}{c}1978 \\
-84\end{array}$ & $\begin{array}{l}\text { Calif. } \\
\text {-south }\end{array}$ & $\begin{array}{c}276.8 \\
(1.2-610)\end{array}$ & & $\begin{array}{c}9.07 \quad \text { Schafer } \\
(0.08-25.6) \\
\frac{\text { et }}{19} \frac{\mathrm{al}}{84},\end{array}$ \\
\hline $\begin{array}{c}1984 \\
-87\end{array}$ & $\begin{array}{l}\text { S. Africa } \\
\text {-west }\end{array}$ & $\begin{array}{c}5.46 \\
(0.07-25.25)\end{array}$ & & $\begin{array}{cr}4.10 & \text { de Kock } \\
(0.07-15) & \frac{\text { et }}{1994} \frac{\text { al., }}{199}\end{array}$ \\
\hline
\end{tabular}


TABLE XI

Organochlorine Concentrations (ppm - wet wt.) Reported in the Blubber of the Striped Dolphin (Stenella coeruleoalba).

Mean Values; Ranges in Parentheses.

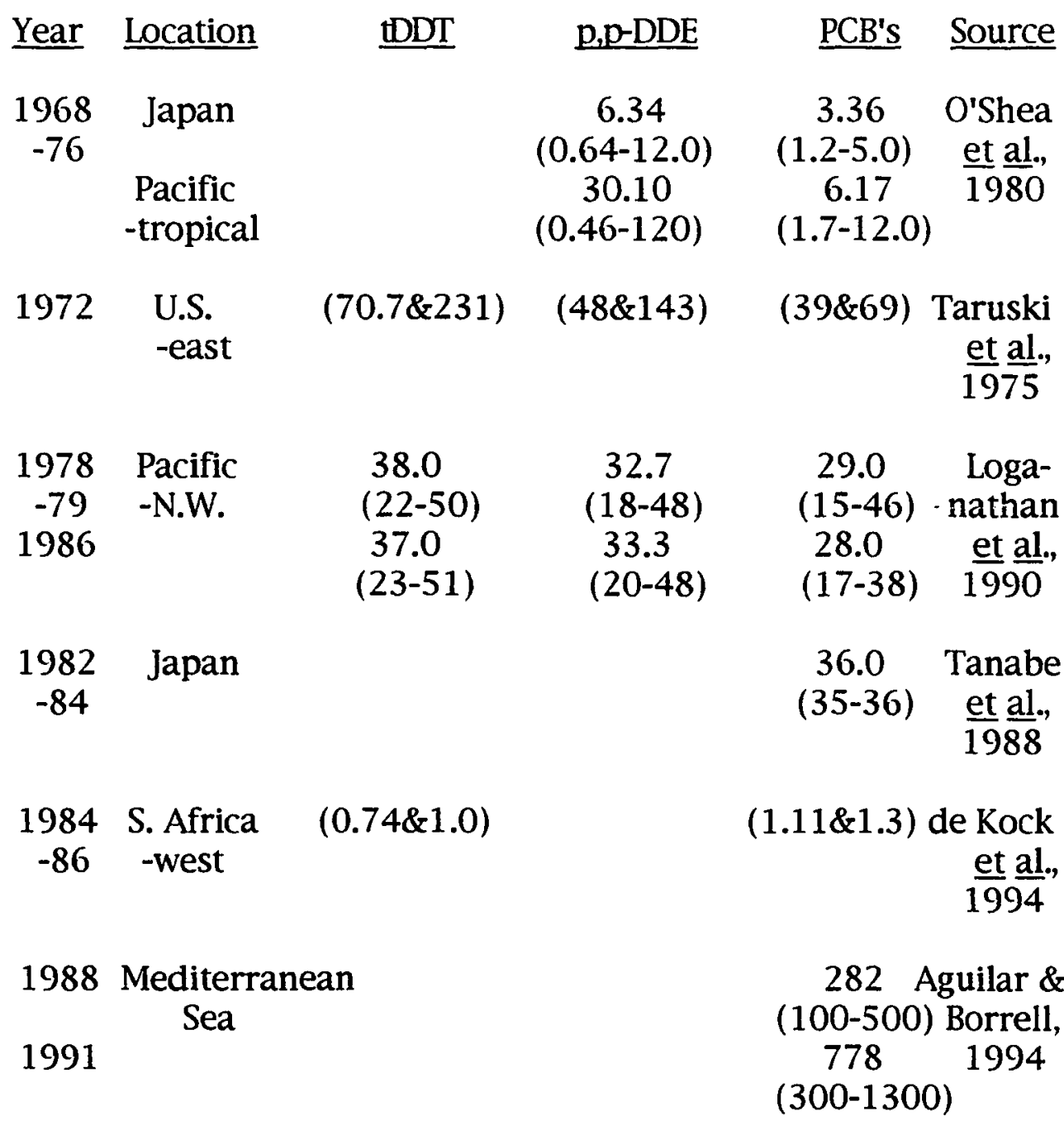


TABLE XII

Organochlorine Concentrations (ppm - wet wt.) Reported in the Blubber of the Beluga (Delphinapterus leucas).

Mean Values; Ranges in Parentheses.

\begin{tabular}{|c|c|c|c|c|c|}
\hline Year & Location & tDDT & p,p-DDE & PCB's & Source \\
\hline 1972 & $\begin{array}{c}\text { Canada } \\
\text {-subarctic }\end{array}$ & $\begin{array}{c}3.9 \\
\pm 0.89\end{array}$ & $\begin{array}{r}1.33 \\
\pm 0.33\end{array}$ & & $\begin{array}{c}\text { Idison \& } \\
\text { Brodie, } \\
1973\end{array}$ \\
\hline $\begin{array}{c}1982 \\
-85\end{array}$ & $\begin{array}{c}\text { Canada } \\
\text {-St. Law. R. }\end{array}$ & $\begin{array}{c}58.0 \\
(1.17-225)\end{array}$ & $\begin{array}{c}33.46 \\
(0.5-136)\end{array}$ & $\begin{array}{c}141.4 \\
(5.6-576)\end{array}$ & $\begin{array}{r}\text { Martin- } \\
\text { eau } \\
\text { et al., } \\
1987\end{array}$ \\
\hline $\begin{array}{c}1983 \\
-87\end{array}$ & $\begin{array}{c}\text { Canada } \\
\text {-subarctic }\end{array}$ & $\begin{array}{c}2.46 \\
(0.18-9.73)\end{array}$ & $\begin{array}{c}1.30 \\
(0.11-4.93)\end{array}$ & $\begin{array}{c}2.37 \\
(0.31-6.73)\end{array}$ & $\begin{array}{l}\text { Muir } \\
\text { et al., } \\
1990\end{array}$ \\
\hline $\begin{array}{c}1986 \\
-87\end{array}$ & $\begin{array}{c}\text { Canada } \\
\text {-St. Law. R. }\end{array}$ & $\begin{array}{c}\mathrm{a}_{1} 01.0 \\
(2.4-123) \\
\mathrm{b}_{23.0} \\
(3.95-42.7) \\
\text { a) fer }\end{array}$ & $\begin{array}{c}65.8 \\
(38.5-80.6) \\
13.9 \\
(1.73-26.8) \\
\text { ales b) } \mathrm{s}\end{array}$ & $\begin{array}{c}75.8 \\
(53.9-89.2) \\
37.3 \\
(14.5-68.7) \\
\text { des }\end{array}$ & $\begin{array}{l}\text { Beland } \\
\text { 2) } \frac{\text { et al., }}{1992} \frac{\text { al }}{\text { 7) }}\end{array}$ \\
\hline
\end{tabular}




\section{TABLE XIII}

Organochlorine Concentrations (ppm - wet wt.) Reported in the Blubber of the Harbor Porpoise (Phocoena phocoena). Mean Values; Ranges in Parentheses.

\begin{tabular}{|c|c|c|c|c|c|}
\hline Year & Location & DDT & $\mathrm{p}, \mathrm{p}-\mathrm{DDE}$ & PCB's & Source \\
\hline 1966 & $\begin{array}{l}\text { Scotland } \\
\text {-east }\end{array}$ & $\begin{array}{c}43.0 \\
(27.9-55.3)\end{array}$ & $\begin{array}{c}12.8 \\
(9.6-15.3)\end{array}$ & & $\begin{array}{l}\text { Holden \& } \\
\text { Marsden, }\end{array}$ \\
\hline 1967 & -Orkneys & 3.9 & 1.1 & & 1967 \\
\hline 1970 & Holland & $\begin{array}{c}41.2 \\
(11.1-102)\end{array}$ & & $\begin{array}{c}88.0 \\
(35-148)\end{array}$ & $\begin{array}{l}\text { Koeman } \\
\text { et } \frac{\text { al.., }}{1972}\end{array}$ \\
\hline 1972 & Greenland & & $\begin{array}{c}0.32 \\
(0.045-0.6)\end{array}$ & $\begin{array}{c}6.65 \\
(1.9-11.4\end{array}$ & $\begin{array}{l}\text { Clausen } \\
\text { 4) } \frac{\text { et al. }}{1974}\end{array}$ \\
\hline 1973 & Rhode Is. & 57.5 & 20.0 & 74.0 & $\begin{array}{l}\text { Taruski } \\
\text { et al., } \\
1975\end{array}$ \\
\hline 1975 & $\begin{array}{l}\text { Calif. } \\
\text {-south }\end{array}$ & 334.8 & 270.0 & 84.0 & $\begin{array}{l}\text { O'Shea } \\
\text { et al., } \\
1980\end{array}$ \\
\hline 1976 & Baltic Sea & $\begin{array}{c}37.6 \\
(29.3-45.9) \\
2.4\end{array}$ & & $\begin{array}{c}114 \\
(88.6-140) \\
15.2\end{array}$ & $\begin{array}{r}\text { Harms } \\
\frac{\text { et al. }}{1978},\end{array}$ \\
\hline
\end{tabular}




\begin{tabular}{|c|c|c|c|c|c|}
\hline $\begin{array}{c}1980 \\
-86\end{array}$ & Calif. & & $\begin{array}{c}42.8 \\
(6.3-131.8)\end{array}$ & $\begin{array}{c}14.2 \\
(2.6-63.6)\end{array}$ & $\begin{array}{l}\text { Calam- } \\
\text { bokidis }\end{array}$ \\
\hline $\begin{array}{c}1981 \\
-86\end{array}$ & Oregon & & $\begin{array}{c}19.2 \\
(2.1-52.1)\end{array}$ & $\begin{array}{c}10.9 \\
(1.4-49.6)\end{array}$ & $\begin{array}{c}\& \\
\text { Barlow, }\end{array}$ \\
\hline $\begin{array}{c}1981 \\
-86\end{array}$ & Washington & & $\begin{array}{c}14.4 \\
(0.2-26.7)\end{array}$ & $\begin{array}{c}17.3 \\
(0.2-29.9)\end{array}$ & 1991 \\
\hline $\begin{array}{c}1986 \\
-88\end{array}$ & $\begin{array}{l}\text { Denmark } \\
\text { Greenland }\end{array}$ & $\begin{array}{c}17.6 \\
(0.7-61.4) \\
(0.8 \& 9.2)\end{array}$ & $\begin{array}{c}6.89 \\
(0.34-26.4) \\
(0.46 \& 5.85)\end{array}$ & $\begin{array}{c}13.1 \\
(1.5-48.4) \\
(0.7 \& 4.5)\end{array}$ & $\begin{array}{c}\text { Granby } \\
\& \\
\text { Kinze, } \\
1991\end{array}$ \\
\hline $\begin{array}{r}1987 \\
-89\end{array}$ & $\begin{array}{l}\text { Canada } \\
-S . W .\end{array}$ & $\begin{array}{c}12.5 \\
(2.2-25.9)\end{array}$ & & $\begin{array}{c}11.9 \\
(4.0-35.3)\end{array}$ & $\begin{array}{l}\text { Muir } \\
\frac{\mathrm{et}}{19} \frac{\mathrm{al}}{91} \text {, }\end{array}$ \\
\hline $\begin{array}{c}1987 \\
-91\end{array}$ & Norway & $\begin{array}{c}16.4 \\
(3.2-45.1)\end{array}$ & $\begin{array}{c}7.2 \\
(1.2-18.6) \\
\text { ppm - lipid }\end{array}$ & $\begin{array}{c}23.3 \\
(3.7-65.3)\end{array}$ & $\begin{array}{l}\text { Kleivane } \\
\frac{\text { et al. }}{19} \overline{95}\end{array}$ \\
\hline
\end{tabular}


TABLE XIV

Organochlorine Concentrations (ppm - wet wt.) Reported in the Blubber of Other Odontocetes.

Mean; Values in Parentheses.

\begin{tabular}{|c|c|c|c|c|c|}
\hline Year & Location & tDDT & $\mathrm{p}, \mathrm{p}-\mathrm{DDE}$ & PCB's & Source \\
\hline \multicolumn{6}{|c|}{ Long-Finned Pilot Whale (Globicephala melaena) } \\
\hline 1972 & $\begin{array}{l}\text { U.S. } \\
\text {-east }\end{array}$ & $(30.3 \& 268)$ & $(21 \& 187)$ & $(42 \& 114)$ & $\begin{array}{l}\text { Taruski } \\
\frac{\text { et }}{19} \frac{\text { all., }}{22}\end{array}$ \\
\hline \multirow[t]{2}{*}{1980} & $\begin{array}{l}\text { Canada } \\
\text {-S.E. }\end{array}$ & $\begin{array}{c}a_{11} .9 \\
(6.4-22.3)\end{array}$ & $\begin{array}{c}5.65 \\
(1.7-3.2)\end{array}$ & $\begin{array}{c}9.03 \\
(4.3-14.7)\end{array}$ & $\begin{array}{l}\text { Muir } \\
\text { et al., }\end{array}$ \\
\hline & & $\begin{array}{c}\text { b } 4.7 \\
(1.03-16.4)\end{array}$ & $\begin{array}{c}2.22 \\
(0.2-10.8)\end{array}$ & $\begin{array}{c}3.46 \\
(0.5-11.8)\end{array}$ & \\
\hline
\end{tabular}
a) males
b) females

Short-Finned Pilot Whale (Globicephala macrorhynchus)

\begin{tabular}{|c|c|c|c|c|c|}
\hline $\begin{array}{c}1968 \\
-76\end{array}$ & $\begin{array}{l}\text { Japan } \\
\text { Calif. } \\
\text {-south }\end{array}$ & & $\begin{array}{c}3.17 \\
(0.56-5.2) \\
(30 \& 110)\end{array}$ & $\begin{array}{c}9.24 \\
(0.6-32) \\
(8.8 \& 14)\end{array}$ & $\begin{array}{l}\text { O'Shea } \\
\frac{\text { et }}{19} \frac{\text { al., }}{80}\end{array}$ \\
\hline 1972 & $\begin{array}{l}\text { Lesser } \\
\text { Antilles }\end{array}$ & $\begin{array}{c}1.62 \\
(1.3-2.3)\end{array}$ & $\begin{array}{c}0.93 \\
(0.83-1.7)\end{array}$ & $\begin{array}{c}1.13 \\
(0.7-1.6)\end{array}$ & $\begin{array}{l}\text { Gaskin } \\
\frac{\text { et }}{1974} \frac{\text { al. }}{74}\end{array}$ \\
\hline
\end{tabular}


Pacific White-Sided Dolphin (Lagenorhynchus obliquidens)

\begin{tabular}{|c|c|c|c|c|c|}
\hline 1982 & Japan & 99.0 & 87.0 & 71.0 & $\begin{array}{l}\text { Tanabe } \\
\qquad \frac{\text { et }}{19} \underline{83} .\end{array}$ \\
\hline 1977 & Calif. & 2.08 & & 0.23 & Schafer \\
\hline 1982 & -south & 99.5 & & 4.88 & $\frac{\mathrm{et}}{1984}$ \\
\hline & \multicolumn{5}{|c|}{ White-Beaked Dolphin (Lagenorhynchus albirostris) } \\
\hline 1980 & $\begin{array}{c}\text { Canada } \\
\text {-S.E. }\end{array}$ & $\begin{array}{c}a_{43.4} \\
(4.5-86.8) \\
b_{2} 7.9 \\
(0.9-88.6)\end{array}$ & $\begin{array}{c}25.4 \\
(7.3-64.4) \\
15.6 \\
(2.8-66.6)\end{array}$ & $\begin{array}{c}34.2 \\
(13.4-87) \\
22.0 \\
(9.6-39.7)\end{array}$ & $\begin{array}{l}\text { Muir } \\
\text { et al., } \\
\text { 1988b }\end{array}$ \\
\hline
\end{tabular}

Spinner Dolphin (

$1972 \begin{array}{lrr}\text { Lesser } & (1.4 \& 7.4) \quad(1.2 \& 6.7) \quad(2.0 \& 5.0) & \text { Gaskin } \\ \text { Antilles } & & \text { et } \frac{\text { al. }}{1974}\end{array}$

1982 Japan 0.19 Tanabe

$-84 \quad(0.15-0.23)$ et al., 1988 
False Killer Whale (Pseudorca crassidens)

$\begin{array}{ccccc}1987 & \text { Canada } & 382 & 40.0 & \text { Muir } \\ -89 & \text {-S.W. } & (75.9-1920) & (33.6-45.7) & \frac{\text { et }}{19} \frac{\text { al }}{1} \text {, } \\ & & & & \\ 1988 & \begin{array}{c}\text { Canada } \\ \text {-S.W. }\end{array} & 1405 & 160 & \text { Baird } \\ & & & & \text { et } \frac{\text { all., }}{1989}\end{array}$

Pygmy Killer Whale (Feresa attenuata)

\begin{tabular}{|c|c|c|c|c|c|}
\hline 1975 & Florida & 23.1 & 4.7 & 79.0 & Forrester \\
\hline 1976 & & 4.8 & 2.0 & 0.8 & et al. \\
\hline 1978 & & 26.9 & 18.9 & 36.6 & 1980 \\
\hline
\end{tabular}

Risso's Dolphin (Grampus griseus)

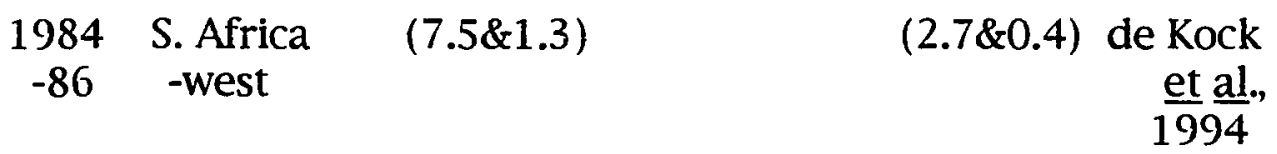

Heaviside's Dolphin (Cephalorhynchus heavisidii)

1982 S. Africa $2.17 \quad 0.65$ de Kock

-87 -west (0.25-4.7) (0.27-1.76) et al., 
Dall's Porpoise (Phocoenoides dalli)

\begin{tabular}{|c|c|c|c|c|c|}
\hline $\begin{array}{c}1968 \\
-76\end{array}$ & $\begin{array}{l}\text { Calif. } \\
\text {-south } \\
\text { Japan }\end{array}$ & 245.8 & 190 & 94.0 & $\begin{array}{l}\text { O'Shea } \\
\frac{\text { et }}{1980} \frac{\text { al. }}{80}\end{array}$ \\
\hline $\begin{array}{c}1982 \\
-84\end{array}$ & Japan & & & $\begin{array}{c}9.0 \\
(8.9-9.1)\end{array}$ & $\begin{array}{l}\text { Tanabe } \\
\text { et al., } \\
1988\end{array}$ \\
\hline 1986 & $\begin{array}{l}\text { Pacific } \\
\text {-north }\end{array}$ & & $\begin{array}{c}12.0 \\
(1.3-15)\end{array}$ & $\begin{array}{c}12.0 \\
(1.0-16)\end{array}$ & $\begin{array}{c}\text { Subra- } \\
\text { manian } \\
\frac{\text { et al.., }}{1988}\end{array}$ \\
\hline
\end{tabular}

Narwhal (Monodon monoceros)

\begin{tabular}{|c|c|c|c|c|c|}
\hline $\begin{array}{c}1982 \\
-83\end{array}$ & $\begin{array}{l}\text { Canada } \\
\text {-arctic }\end{array}$ & $\begin{array}{c}\text { a5.92 } \\
(2.6-8.6)\end{array}$ & $\begin{array}{c}2.55 \\
(1.2-3.7)\end{array}$ & $\begin{array}{c}5.18 \\
(2.3-7.3)\end{array}$ & $\begin{array}{l}\text { Muir } \\
\text { et al., }\end{array}$ \\
\hline & & $\begin{array}{c}\text { b2.54 } \\
(0.6-5.9)\end{array}$ & $\begin{array}{c}1.46 \\
(0.3-4.0)\end{array}$ & $\begin{array}{c}2.70 \\
(0.9-5.7)\end{array}$ & 1992 \\
\hline
\end{tabular}

Blainville's Beaked Whale (Mesoplodon densirostris)

$\begin{array}{cccccc}1972 & \text { U.S. } & (3.8 \& 65.1) & (19 \& 22) & (14 \& 29) & \begin{array}{r}\text { Taruski } \\ \text { et al., } \\ 1975\end{array} \\ & \text {-east } & & & & \\ & & & & 0.42 & \text { de Kock } \\ 1984 & \text { S. Africa } & 0.79 & & (0.29-0.88) & \underline{\text { et al., }} \\ -86 & \text {-west } & (0.29-1.86) & & 1994\end{array}$


Sperm Whale (Physeter catodon)

\begin{tabular}{|c|c|c|c|c|c|}
\hline 1968 & $\begin{array}{l}\text { central } \\
\text { Calif. }\end{array}$ & $\begin{array}{c}5.30 \\
(1.82-9.4)\end{array}$ & $\begin{array}{c}3.62 \\
(0.74-6.0)\end{array}$ & & $\begin{array}{c}\text { Wolman \& } \\
\text { Wilson, } \\
1970\end{array}$ \\
\hline 1972 & $\begin{array}{l}\text { West } \\
\text { Indies }\end{array}$ & $\begin{array}{c}8.50 \\
(1.1-15.5)\end{array}$ & $\begin{array}{c}5.10 \\
(0.8-9.9)\end{array}$ & $\begin{array}{c}2.27 \\
(0.7-4.0)\end{array}$ & $\begin{array}{l}\text { Taruski } \\
\qquad \begin{array}{c}\text { et al., } \\
1975\end{array}\end{array}$ \\
\hline 1983 & $\begin{array}{l}\text { Calif. } \\
\text {-south }\end{array}$ & 5.08 & & 0.51 & 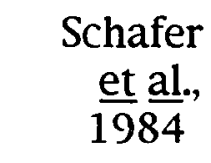 \\
\hline 1986 & $\begin{array}{l}\text { S. Africa } \\
\text {-west }\end{array}$ & 0.39 & & 0.26 & $\begin{array}{l}\text { de Kock } \\
\frac{\text { et }}{1994} \frac{\text { al. }}{\text {. }}\end{array}$ \\
\hline
\end{tabular}

Pygmy Sperm Whale (Kogia breviceps)

$\begin{array}{ccccc}1978 & \text { S. Africa } & 0.65 & 0.406 & \text { de Kock } \\ -87 & \text {-west } & (0.3-1.11) & (0.12-1.1) & \text { et al., } \\ & & & & 1994\end{array}$

Dwarf Sperm Whale (Kogia simus)
1976 S. Africa 0.75
-84 -west $(0.37-1.43)$
$\begin{array}{cr}0.25 & \text { de Kock } \\ (0.15-0.38) & \text { et al., } \\ 1994\end{array}$ 
TABLE XV

Organochlorine Concentrations (ppm - wet wt.) Reported in the Blubber of Mysticetes.

Mean Values; Ranges in Parentheses.

\begin{tabular}{|c|c|c|c|c|c|}
\hline Year & Location & tDDT & $\mathrm{p}, \mathrm{p}-\mathrm{DDE}$ & PCB's & $\underline{\text { Source }}$ \\
\hline \multicolumn{6}{|c|}{ Minke Whale (Balaenoptera acutorostrata) } \\
\hline 1976 & $\begin{array}{l}\text { Puget } \\
\text { Sound }\end{array}$ & & 0.55 & 0.15 & $\begin{array}{l}\text { Calam- } \\
\text { bokidis } \\
\quad \underline{\text { et al., }} \\
1984\end{array}$ \\
\hline 1977 & $\begin{array}{l}\text { Calif. } \\
\text {-south }\end{array}$ & 587 & & 27.8 & $\begin{array}{l}\text { Schafer } \\
\text { et al., } \\
1984\end{array}$ \\
\hline 1984 & $\begin{array}{l}\text { S. Africa } \\
\text {-west }\end{array}$ & 0.08 & & 0.01 & $\begin{array}{r}\text { de Kock } \\
\frac{\text { et }}{1994} \frac{\text { al. }}{}\end{array}$ \\
\hline
\end{tabular}

Gray Whale (Eschrichtius robustus)

1968 central

$\begin{array}{ll}0.311 & 0.139\end{array}$

Calif.

(0.14-0.68)

$(0.04-0.3)$

Wolman \&

Wilson, 1970 


\section{CHAPTER III}

THE USE OF HPLC FOR THE ESTIMATION OF PCB AND DDE RESIDUES IN MARINE MAMMALS

\section{INTRODUCTION}

Organochlorines have become an ubiquitous part of the Earth's environment since their introduction in the 1940's. While the DDT family of pesticides are highly effective control agents with low toxicity to mammals and a high degree of persistence (Brooks, 1974), this persistence, along with their high solubility in lipids, has led to accumulation of varying concentrations of these pesticides and their metabolites in the tissues of many species of organisms. Such an accumulation has resulted in detrimental effects, causing the numbers of many species to plummet and pushing some to the brink of extinction (Keith, 1991). Polychlorinated biphenyls (PCB's), used as industrial fluids and plasticizers, exhibit properties similar to those of the organochlorine pesticides and have been implicated in the decline of many populations of organisms, both terrestrial and aquatic (Clark, 1981; Reijnders, 1986). As a result of these effects on wildlife, the use of the organochlorines has been banned or severely restricted in most of the world's industrialized nations, 
although their use continues in many developing countries (Loganathan \& Kannan, 1994). This action led to a reduction in residues in many affected populations and a rebound in numbers of some species, such as the brown pelican and bald eagle (Anderson et al., 1975; Ohlendorf \& Fleming, 1988). However, other species, especially those that are migratory and spend part of their time in areas where the organochlorines are still being used, continue to exhibit high residue levels and concomitant effects (Keith, 1991; Calambokidis \& Francis, 1994). Most species of marine mammals fall into this latter category, as well as being near the top of the trophic food chains. Monitoring organochlorine residues in these animals, therefore, provides an indication of the continuing presence and levels of these contaminants in the marine environment.

The determination of organochlorine residue levels in organisms has traditionally been done using gas chromatography (GC) and/or thin-layer chromatography (TLC) (Fishbein, 1972;

Fishbein, 1974). Gas chromatography provides a complete, detailed analysis of each organochlorine present, and is defintely the method of choice when such an analysis is desired. However, the most commonly occurring organochlorines found in most organisms are the PCB's and p,p-DDE, a metabolite of DDT (Peterle, 1991). A screening method for the detection of only these two compounds would provide a good approximation of the level of organochlorine contamination in the environment. This type of 
screening could be carried out using high performance liquid chromatography (HPLC), which is generally simpler and less timeconsuming than $\mathrm{GC}$, and it would allow for the examination of a greater number of individual organisms at less cost (Horgan, 1974). It has been demonstrated that both PCB's and p,p-DDE can be detected with HPLC, although the PCB mixture overlaps the p,p-DDE (Brinkman et al., 1976a). By adding an oxidation step which converts $p, p$-DDE to $p, p-D C B P$ (dichlorobenzophenone), good group separation with HPLC occurs and can be utilized to determine the presence and levels of these two organochlorines (Collins et al., 1972; Sherma, 1981). Following this reasoning, a method using HPLC was developed to screen blubber samples of stranded marine mammals for PCB's and p,p-DDE in order to get an indication of the current organochlorine levels in these species. Reported here is the experimental protocol for detecting these compounds in blubber.

\section{EXPERIMENTAL}

\section{Reagents}

n-Hexane, 96\%; Acetonitrile; Chloroform - all HPLC grade (J.T. Baker, Phillipsburg, N.J.).

2-Phenoxyethanol; Ammonium Hydroxide; Acetone; Acetic Acid, glacial - all reagent grade (J.T. Baker, Phillipsburg, N.J.).

Silver Nitrate crystals, Sodium Sulfate, anhydrous; 
Sodium Hydroxide pellets; Sodium Chloride crystals

(J.T. Baker, Phillipsburg, N.J.).

Florisil, PR grade, $60-100$ mesh, activated at $675^{\circ} \mathrm{C}$

(J.T. Baker, Phillipsburg, N.J.).

Chromium Trioxide, technical grade (Mallinckrodt,

St. Louis, Mo.).

\section{Apparatus}

Liquid chromatograph system (Beckman-Altex, Berkeley, Ca.) - consists of Model 110A solvent metering pump, mixing chamber, Model 210A sample injection valve with 25 ul loop, Model 165 variable wavelength detector, Model C1-A integrator-plotter.

Pre-packed HPLC column - 250mm X 4mm id - Lichrosorb Si 60, 5 um (E. Merck, Darmstadt, Ger.).

Uptight guard column packed with Perisorb A, 30-40um (Upchurch Scientific, Oak Harbor, Wa.).

Kuderna-Danish evaporator-concentrator, $250 \& 500 \mathrm{ml}$ flasks, $10 \& 15 \mathrm{ml}$ receiver tubes, 3 ball Snyder column, 2 ball microSnyder column (Kontes Glassware, Vineland, N.J.).

TLC plates, $5 \times 20 \mathrm{~cm}$, aluminum oxide, fluorescenceimpregnated (J.T. Baker, Phillipsburg, N.J.).

Standards

PCB's - Aroclor 1248, 1254, 1260 in hexane, $100 \mathrm{ug} / \mathrm{ml}$;

p,p-DDE, p,p-DDT in hexane, $100 \mathrm{ug} / \mathrm{ml}$; 
Organochlorine pesticide mixture - p,p-DDE \& p,p-DDD @ $500 \mathrm{ug} / \mathrm{ml}, \mathrm{p}, \mathrm{p}-\mathrm{DDT}$, aldrin, heptachlor, \& dieldrin @ $100 \mathrm{ug} / \mathrm{ml}$ in hexane (Ultra Scientific, North Kingstown, $\mathrm{R}, \mathrm{I}$, ).

p,p-dichlorobenzophenone (Aldrich, Milwaukee, Wi.).

\section{Procedure}

Extraction

Blubber samples were acquired from stranded, dead marine mammals and recently-deceased captive animals, and stored frozen at $-20^{\circ} \mathrm{C}$. For analysis, the sample was thawed, a 6-7g piece removed and cut into cubes approximately $1 \mathrm{~cm}$ square, and ground with sand (acidwashed) and hexane in a mortar. The ground sample was warmed in a $50^{\circ} \mathrm{C}$ water bath for $10 \mathrm{~min}$. to soften the tissue, following which $10 \mathrm{~g}$ of sodium sulfate were added. Organochlorines were extracted by grinding the sample mixture with four $30 \mathrm{ml}$ portions of hexane, and decanting off each portion through a Buchner funnel fitted with filter paper into an Erlenmeyer flask. After the final grinding and decanting, the remaining tissue was placed in the Buchner funnel and pressed dry. The combined extracts were then poured through a $60 \mathrm{~mm} \times 22 \mathrm{~mm}$ i.d. column of sodium sulfate to remove water and collected in a Kuderna-Danish evaporator fitted with a $15 \mathrm{ml}$ receiver tube. The combined extracts were concentrated to a volume of less than $15 \mathrm{ml}$. 


\section{Extract Cleanup}

After cooling, the concentrated extract was brought up to a volume of $15 \mathrm{ml}$ with hexane and placed in a $125 \mathrm{ml}$ separatory funnel. To this was added $30 \mathrm{ml}$ of acetonitrile saturated with hexane. The mixture was shaken for $1 \mathrm{~min}$., and the layers were allowed to separate. The bottom acetonitrile layer was run into a second $125 \mathrm{ml}$ separatory funnel containing $15 \mathrm{ml}$ of hexane. This mixture was shaken for $1 \mathrm{~min}$., and the layers were allowed to separate. If emulsions formed in either of these funnels, the mixture was centrifuged at $3000 \mathrm{rpm}$ for $5 \mathrm{~min}$. to separate the layers. The bottom acetonitrile layer in the second funnel was then run into a $1 \mathrm{~L}$ separatory funnel containing $650 \mathrm{ml}$ of distilled water, $40 \mathrm{ml}$ of saturated sodium chloride, and $100 \mathrm{ml}$ of hexane. This procedure was repeated with 3 additional portions of acetonitrile, with a total of $120 \mathrm{ml}$ of acetonitrile being run into the $1 \mathrm{~L}$ funnel. This funnel and its contents were then shaken for $45 \mathrm{sec}$. in a horizontal position, and the layers were allowed to separate. The bottom aqueous layer was run into a second $1 \mathrm{~L}$ separatory funnel containing $100 \mathrm{ml}$ of hexane. The contents of this funnel were shaken in a horizontal position, and the layers were allowed to separate. The bottom aqueous layer was run to waste, and the $100 \mathrm{ml}$ hexane portion in the 
second $1 \mathrm{~L}$ funnel was combined with the $100 \mathrm{ml}$ of hexane in the first $1 \mathrm{~L}$ funnel. The combined portions were washed with two $100 \mathrm{ml}$ portions of water to remove any traces of acetonitrile, with the aqueous layer run to waste both times. The $200 \mathrm{ml}$ of hexane was then run through a $60 \mathrm{~mm} \times 22 \mathrm{~mm}$ i.d. column of sodium sulfate, and collected in a Kuderna-Danish evaporator fitted with a $500 \mathrm{ml}$ flask and a $10 \mathrm{ml}$ receiver tube. The $\mathrm{L}$ funnels were rinsed with two $20 \mathrm{ml}$ portions of hexane, and these were added to the sodium sulfate column. The column was then washed with two $10 \mathrm{ml}$ portions of hexane. The combined extract and washings were concentrated to about $4 \mathrm{ml}$.

After cooling, the $4 \mathrm{ml}$ of hexane containing the organochlorine residues was placed on the top of a $22 \mathrm{~mm}$ id Florisil column. This column consisted of $1 \mathrm{~cm}$ of sodium sulfate, $9 \mathrm{~cm}$ of activated Florisil, and another $1 \mathrm{~cm}$ of sodium sulfate, and was prewetted with $50 \mathrm{ml}$ of hexane just prior to the addition of the sample. The sample was drained in slowly, and the column eluted with $150 \mathrm{ml}$ of hexane at a flow rate of $5 \mathrm{ml} / \mathrm{min}$. The eluate was collected in a Kuderna-Danish evaporator fitted with a $250 \mathrm{ml}$ flask and a $10 \mathrm{ml}$ receiver tube, and concentrated to a volume of $5 \mathrm{ml}$. 
Oxidation of $\mathrm{p}, \mathrm{p}$-DDE to $\mathrm{p}, \mathrm{p}$-Dichlorobenzophenone

The $5 \mathrm{ml}$ eluate was concentrated further to $2 \mathrm{ml}$ using a microSnyder column. To this $2 \mathrm{ml}$ of hexane was added $2 \mathrm{ml}$ of glacial acetic acid, the receiver tube again fitted with a microSnyder column, and the hexane totally evaporated. To the remaining $2 \mathrm{ml}$ of acid now containing the organochlorine residues was added $100 \mathrm{mg}$ of chromium trioxide. The mixture was then placed in a boiling water bath for $30 \mathrm{~min}$., after which the mixture was allowed to cool, and $2 \mathrm{ml}$ of hexane was added. The tube was stoppered and shaken for $30 \mathrm{sec}$. and $7 \mathrm{ml}$ of $5 \mathrm{~N}$ sodium hydroxide was added to neutralize the acid. The tube was shaken for $15 \mathrm{sec}$, and the layers were allowed to separate. The clear top hexane layer contained the organochlorines, and was analyzed with HPLC. The hexane layer was concentrated to $1 \mathrm{ml}$ before HPLC analysis for low residue concentrations.

HPLC Analysis

From each oxidized sample $25 \mathrm{ul}$ was injected into the HPLC system. The mobile phase was hexane:chloroform (95:5) with a flow rate of $1.4 \mathrm{ml} / \mathrm{min}$. The UV absorbance of the eluate from the adsorption column was monitored at $205 \mathrm{~nm}$. The areas of the resulting peaks were electronically integrated and compared with those of injected standards of known concentrations for determination of approximate 
residue levels in the original sample. Confirmation of results from selected samples was accomplished with TLC on aluminum oxide plates with hexane as the mobile phase and a silver nitrate chromogenic reagent after the method of Bishara et al (1972).

\section{RESULTS}

The retention times of PCB's and p,p-DDE in this system are similar at about 2.1 min. Figure 6 illustrates the peaks obtained with standard solutions of Aroclor 1254 and p,p-DDE. Oxidation of the Florisil eluate containing these two substances was performed in order to obtain separation. The p,p-DDE is oxidized to $p, p-$ dichlorobenzophenone (DCBP) while the PCB's are unaffected. The p,p-DCBP exhibits a longer retention time than the PCB's. This is illustrated in Figure 7 which shows the peaks of both standard $p, p-D C B P$ and an oxidized sample of p,p-DDE. An oxidized mixture containing standard Aroclor 1260 and p,p-DDE which had been converted to $p, p-D C B P$ is shown in Figure 8, illustrating the group separation achieved. Using this procedure, samples of marine mammal blubber were examined. Figures 9 and 10 illustrate that PCB's and p,p-DDE can be detected in these animals.

Semiquantification was done by comparing integrated peak areas with those of known standards. Results obtained are also given in Figures 9 and 10. 


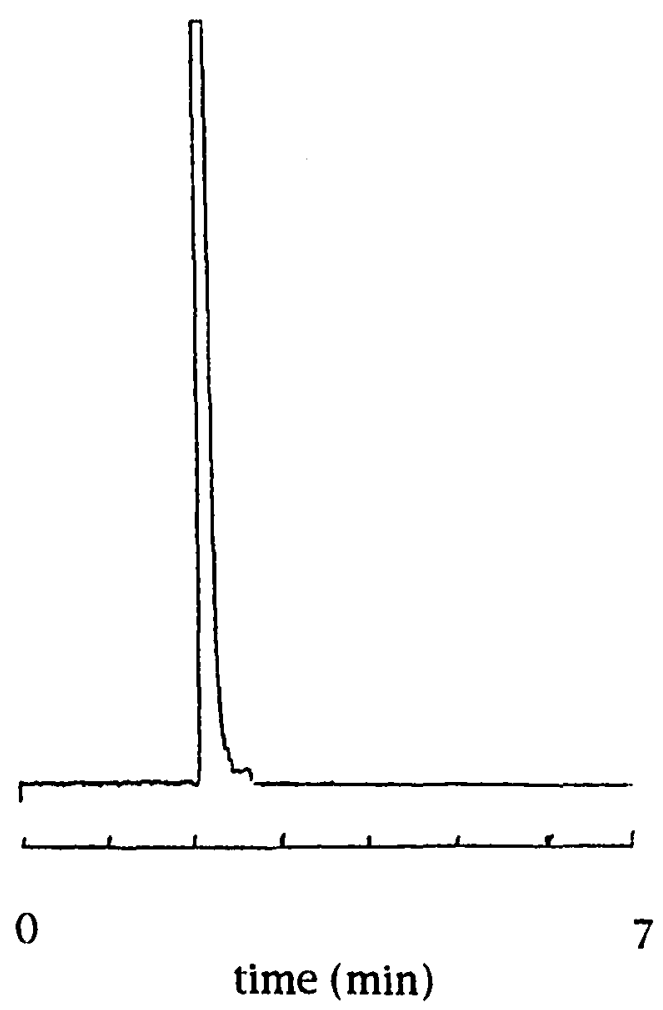

(a)

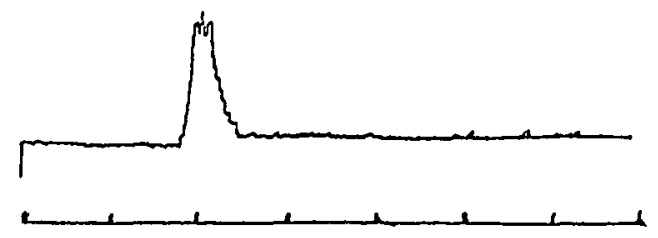

0

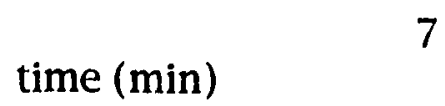

(b)

Figure 6. HPLC chromatograms of (a) p,p-DDE@ $100 \mathrm{ug} / \mathrm{g}$, and (b) Aroclor $1254 @ 100 \mathrm{ug} / \mathrm{g}$. 


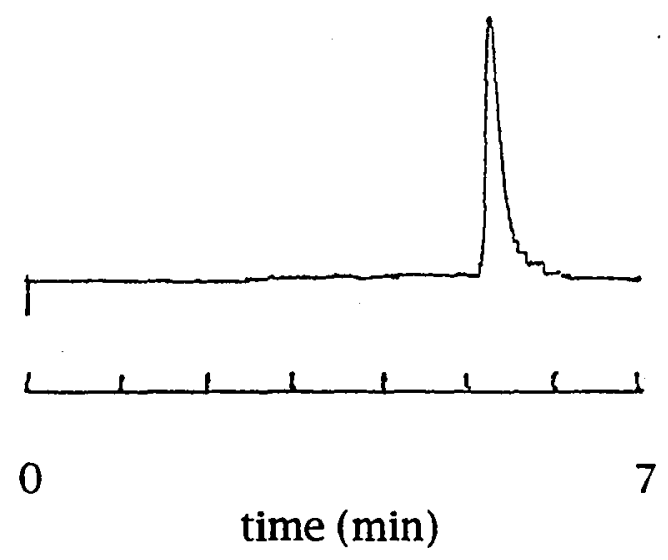

(a)

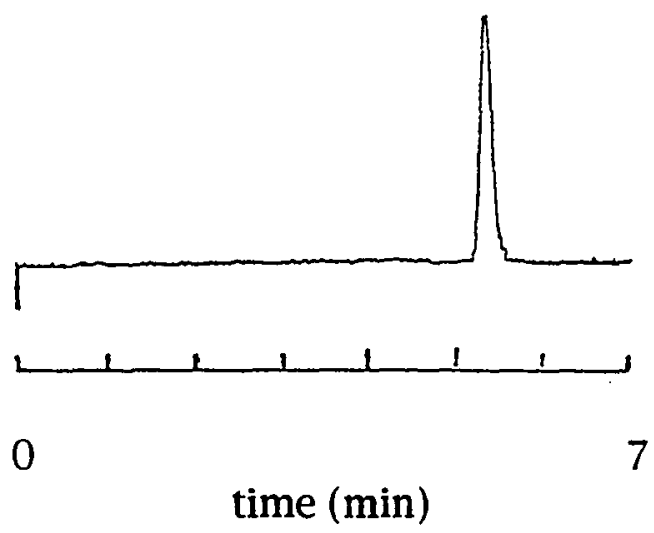

(b)

Figure 7. HPLC chromatograms of (a) oxidized p,p-DDE@ 10 ug/g, and (b) p,p-DCBP@10 ug/g. 


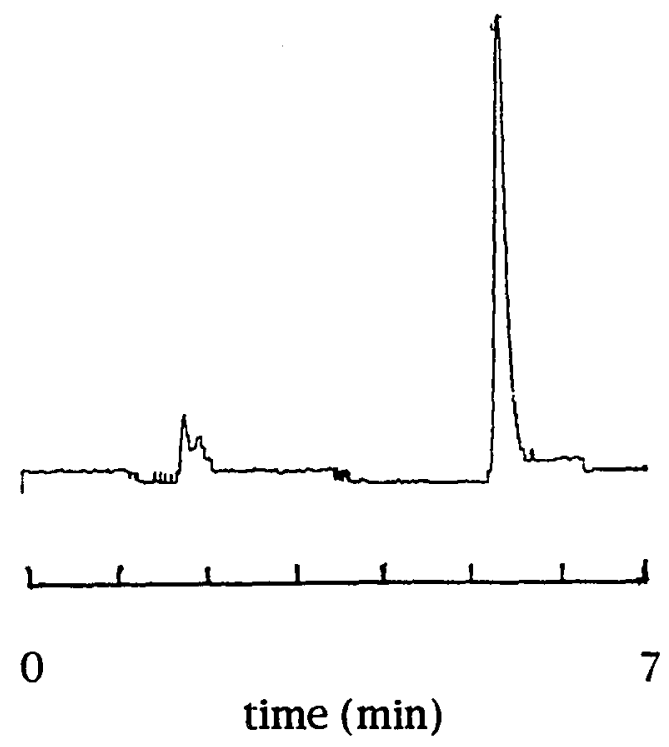

Figure 8. HPLC chromatogram of oxidized Aroclor $1260 @ 100$ $\mathrm{ug} / \mathrm{g}$, and p,p-DDE@ $50 \mathrm{ug} / \mathrm{g}$. 


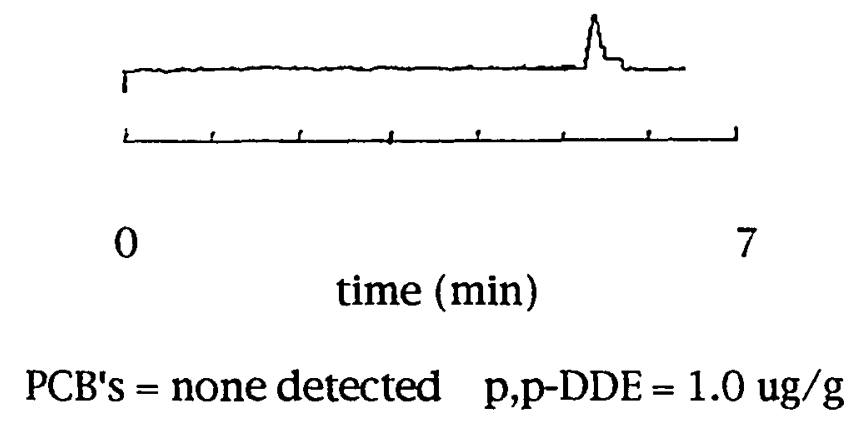

(a)

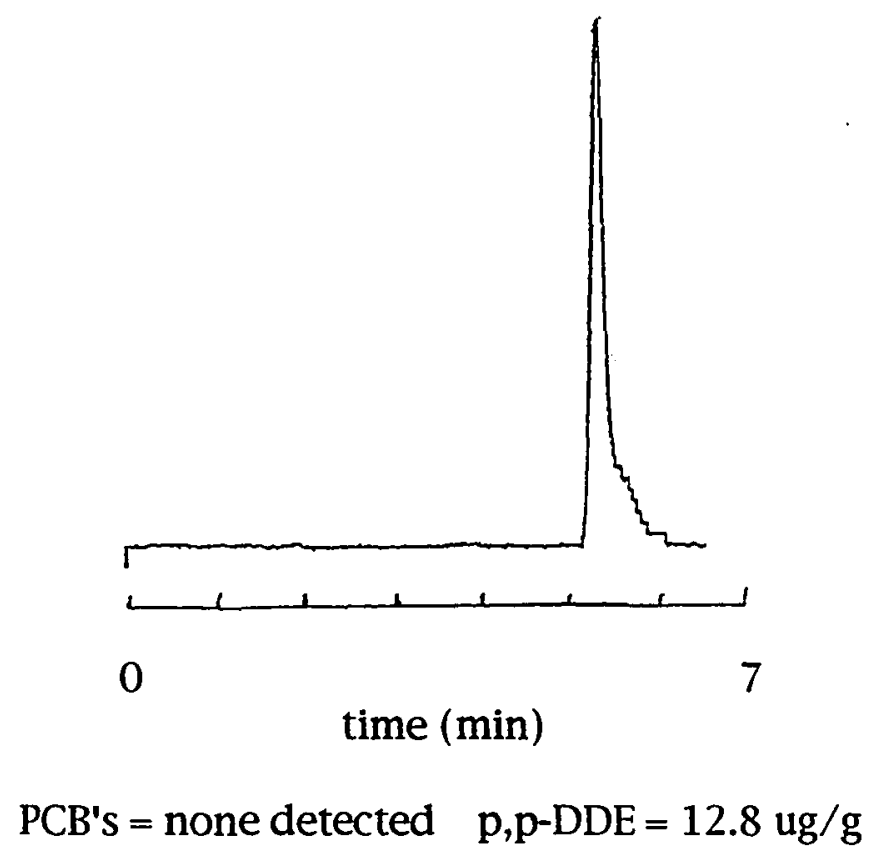

(b)

Figure 9. HPLC chromatograms of (a) harbor seal (Phoca vituluna), and (b) California sea lion (Zalophus californianus). 


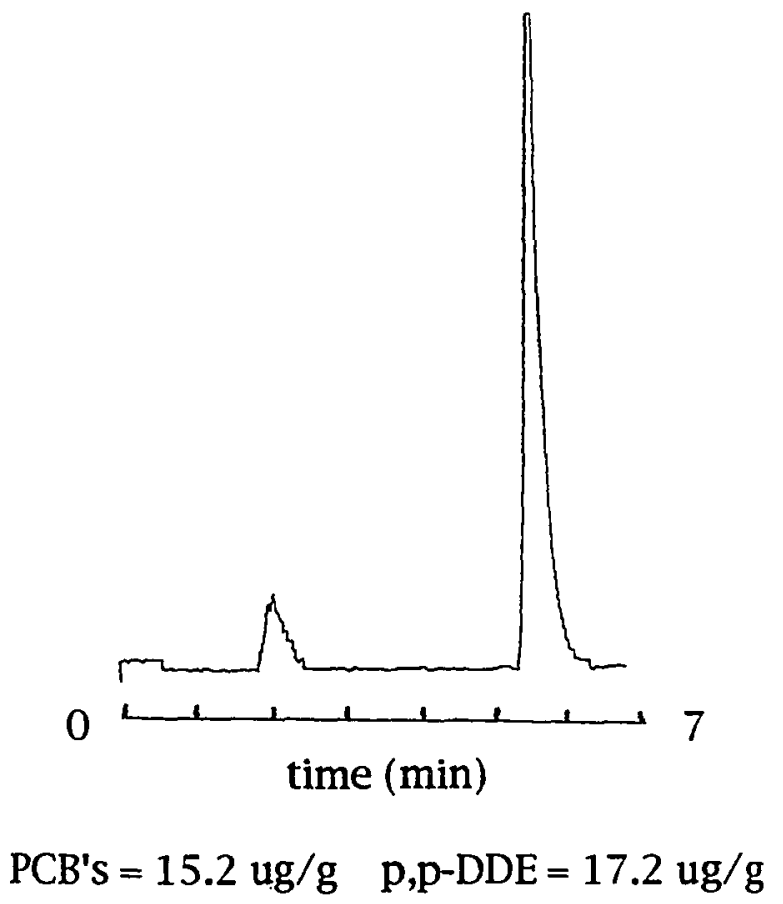

(a)

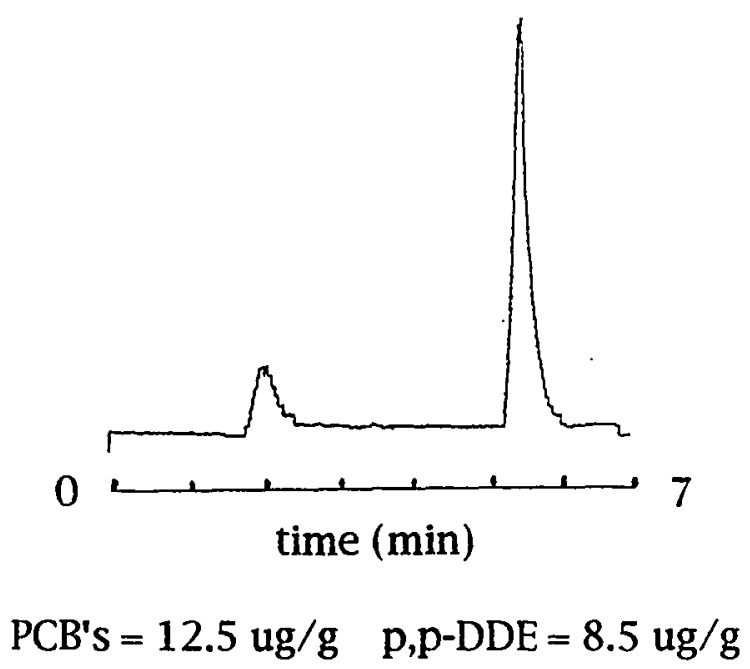

(b)

Figure 10. HPLC chromatograms of (a) pilot whale

(Globicephala macrorhynchus), and

Commerson's dolphin (Cephalorhynchus commersonii). 
DISCUSSION

The experimental procedure described above for the extraction and cleanup of organochlorine residues follows that given in the literature with modifications found to be necessary when dealing with marine mammal blubber and for use with HPLC (McMahon \& Hardin, 1994). The multiresidue method, on which these modifications are based, is recommended by the U.S. Food and Drug Administration, and allows for the complete determination of the presence and levels of organochlorines in a sample. It involves the elution of the Florisil column with consecutively different mobile phases, such as petroleum ether elution, followed by elution with $6 \%$ ethyl ether-petroleum ether, then $15 \%$ ethyl ether-petroleum ether, ending with a $50 \%$ elution. This Florisil elution has been modified by other workers, with the first elution using hexane as the mobile phase, followed by $30 \%$ methylene chloride-hexane, and ending with $50 \%$ methylene chloride-hexane (Calambokidis et al., 1984). The screening of tissues for the presence of PCB's and p,p-DDE requires only the hexane eluate, which contains these two organochlorines along with o,p-DDE, aldrin, heptachlor, mirex, hexachlorobenzene, and some o,p-DDT and trans-nonachlor present in the sample (Reynolds, 1969; Calambokidis et al., 1984). The remaining organochlorines are eluted in the other fractions. Ultraviolet absorption by the organochlorines other than PCB's and p,p-DDE present in the hexane fraction is poor or nonexistent at the 
concentrations encountered in marine mammals, so PCB's and p,pDDE can be determnined using a UV detector without interference from any other organochlorine contaminants (Dolan \& Seiber 1977; Osselton \& Snelling 1986). Since the UV detector is the one most often used in HPLC, screening tissues for these two organochlorines proved especially feasible using this technique.

DDE and PCB's are the most commonly occurring organochlorines currently found in marine mammals blubber, with $p, p-D D E$ representing by far the largest percentage of total DDE. Since DDE and PCB's are usually present in the highest concentrations of all the organochlorines found, a screening process for organochlorine contamination in these animals need only detect these two substances (Brooks, 1974; Addison \& Zinck, 1986; Law et a‥, 1989; Luckas et al., 1990; Calambokidis \& Barlow, 1991; Kleivane et al., 1995). Further, since DDE is the most common metabolite of DDT now in marine mammals, the determination of DDE levels also provides a good approximation of total DDT accumulation (Loganathan et al., 1990; Brandt et al., 1992; Calambokidis \& Francis, 1994; Kleivane et al., 1995).

One of the major problems in the detection and quantification of $p, p-D D E$ and PCB's is that the two compounds have similar retention times in GC, TLC, and HPLC systems (Fishbein, 1972; Fishbein, 1974). Brinkman et al. (1976a) demonstrated that a mixture of Aroclors overlapped the peak of p,p-DDE in HPLC when using an adsoprtion column. Figure 6 
illustrates the same occurrence with the system used in this investigation. The retention time of $\mathrm{p}, \mathrm{p}-\mathrm{DDE}$ is approximately 2.1 min. (Figure $6(\mathrm{a})$ ), while that of Aroclor 1254 extends from 2.0$2.2 \mathrm{~min}$. (Figure 6 (b)). A variety of methods have been devised to overcome this problem, including column chromatography and chemical derivatization (Armour \& Burke, 1970; Snyder \& Reinert, 1971; Rosewell \& Baker, 1979). The oxidation of p,p-DDE to p,pDCBP, a process which does not affect the PCB's, has been shown to allow the separation and semiquantitative determination of $\mathrm{PCB}$ and p,p-DDE residues by GC or TLC (Mulhern et al., 1971; Miles, 1972; Collins et al., 1972). In this investigation the same was found with adsorption HPLC. Oxidized $\mathrm{p}, \mathrm{p}-\mathrm{DDE}$ has a retention time of about $5.5 \mathrm{~min}$. (Figure 7 (a)), approximately the same retention time of standard p,p-DCBP (Figure $7(b)$ ). The retention time of PCB's, as represented by Aroclor 1254, remains the same at 2.0-2.2 min (Figure $6(\mathrm{~b})$ ). HPLC, therefore, provides good separation of PCB's from p,p-DDE, allowing for a determination of their presence and approximate levels (Figure 8).

Chromatograms of cleaned, oxidized extracts of samples of four different species of marine mammals are illustrated in Figures 9 and 10. PCB's and p,p-DDE are both present in two of the samples (Figure 10), while only p,p-DDE is present in the other two (Figure 9). Estimation of concentration was done by comparing the average peak area of PCB's and p,p-DDE from four separate runs with peak areas for standards of Aroclor 1254 and 
$p, p-D C B P$. Since the peak area of $p, p-D D E$ and $p, p-D C B P$ were found to be approximately the same at the same concentrations, an estimation of the concentration of $p, p-D C B P$ provided an estimation of the concentration of $p, p-D D E$. Following the suggestion of Bakalyar \& Henry (1976), peak areas were used rather than peak heights, as flow rate could be precisely controlled in this system, whereas mobile phase composition could not. Indeed slight changes in mobile phase over time could be noticed in the retention time drifting of p,p-DCBP from 5.5-5.7 min. Figures 9 and 10 provide the concentrations of PCB's and p,p-DDE from the four marine mammal samples, concentrations determined using this method of peak area comparison. Values obtained are consistent with those reported in the literature for these species (Calambokidis et al., 1984; Calambokidis \& Francis, 1994). Residues of PCB's could be detected down to $1 \mathrm{ug} / \mathrm{g}$ ( 1 $\mathrm{ppm})$, those of p,p-DDE down to $0.5 \mathrm{ug} / \mathrm{g}(0.5 \mathrm{ppm})$. Extracts from organically raised cattle, as well as from long-term captive marine mammals, showed no detectable residues, and thus served as controls.

Recovery experiments were performed by spiking four different samples of marine mammals and one of cattle for which residue levels had already been determined with known concentrations of Aroclor 1254 and p,p-DDE. In addition, standard solutions of both of these contaminants were run through the entire experimental protocol to determine recovery. It was found 
that recovery of Aroclor 1254 averaged $82.5 \pm 11.7 \%$, while that of p,p-DDE averaged $85.6 \pm 9.3 \%$. A validation of the method and recovery was performed using a sample of whale blubber which had been thoroughly analyzed by the U.S. National Institute of Standards and Technology (NIST). Recoveries from this sample, SRM-1945, were $81.6 \%$ for p,p-DDE, and $82.5 \%$ for PCB's.

\section{CONCLUSIONS}

HPLC can be used to screen blubber samples from marine mammals for the presence of organochlorines, specifically PCB's and p,p-DDE. It also has the potential to do so for other organisms. Although it cannot replace GC for detailed analysis of organochlorines, it can provide a good semiquantitative estimate of the concentrations of the two specific contaminants. It can do so more economically than $\mathrm{GC}$, and would be useful in a laboratory which had no access to a GC. Since many biological laboratories possess an HPLC system already, it would be quite feasible for them to conduct organochlorine screening using this system. 


\section{CHAPTER IV}

\section{THE SEMIQUANTITATIVE DETERMINATION OF PCB'S}

AND DDE IN STRANDED MARINE MAMMALS

USING HPLC

\section{INTRODUCTION}

Organochlorines are ubiquitous pollutants of the marine environment. Although banned in many countries, use of these substances continues, especially in the tropics (Goldberg, 1991; Loganathan \& Kannan, 1994). Because of increased volatility in these warmer regions and long range transport in the atmosphere, these pollutants attain worldwide distribution (Tanabe, 1988; Oehme, 1991; Wania \& Mackay, 1993). Pristine regions such as the Arctic have been contaminated by the organochlorines, as have been all the world's oceans (Cotham \& Biddleman, 1991; Barrie et al., 1992; lwata et al., 1993). Being highly persistent, these compounds accumulate in organisms, especially those that have relatively poor metabolic and excretory capabilities (Tanabe et al., 1988; Tanabe et al., 1994). Such accumulation becomes greater in organisms higher in the food chain, leading to biomagnification in top level predators, such as fish-eating birds and most marine mammals (Kilgore \& Li, 1976; Tanabe et al., 1984; Peterle, 1991). This accumulation is most often detected in 
blubber or fat tissue due to the high lipid solutbility of these contaminants (Holden \& Marsden, 1967; Brooks, 1974; Hutzinger et al., 1974; Matsumura, 1975).

Polychlorinated biphenyls (PCB's) and DDE have been found in high concentrations in the blubber of marine mammals (Koeman et al., 1972; O'Shea et al., 1980; Calambokidis et al., 1984; Aguilar \& Borrell, 1994). PCB's were used in industrial formulations, while DDE is the major stored metabolite in marine mammals of the insecticide DDT (Fishbein, 1972; Borrell \& Aguilar, 1987). The two substances are highly persistent, and have been linked to many chronic problems found in marine mammals, ranging from neoplasms to dysfunctions in the reproductive and immune systems (Reijnders, 1986; Beland et al., 1992; Reijnders, 1994; de Swart et al., 1994). Presence of PCB's and DDE is usually determined using gas chromatography (GC) or thin-layer chromatography (TLC) (Sherma \& Zweig, 1983; Sherma \& Zweig, 1985). High performance liquid chromatography (HPLC) has been little used because of poor ultraviolet (UV) absorbance properties of many of the organochlorines (Dolan \& Seiber, 1977; Osselton \& Snelling, 1986). However, it has been demonstrated that PCB's and DDE do absorb UV well enough at shorter wavelengths that HPLC could be used for the detection and semiquantification of these two compounds (Brinkman et al., 1976a; Chiosi et al al., 1982). Since these two substances are the most commonly occurring organochlorines in marine mammals, HPLC could therefore be 
used to screen such animals for organochlorine contamination (Addison \& Zinck, 1986; Law et al.., 1989; Luckas et al., 1990;

Calambokidis \& Barlow, 1991; Kleivane et al., 1995). This would be especially useful for biological laboratories, which often possess HPLC systems, but have no access to a gas chromatograph. With these facts in mind, an HPLC procedure was developed and used in this study to identify and approximate the concentration of PCB's and p,p-DDE in the blubber of a variety of stranded marine mammals.

\section{MATERIALS AND METHODS}

Blubber samples were obtained from stranded animals in various locations and stored frozen. At the time of analysis the samples were thawed, cut into cubes, and ground in a mortar with sand, hexane and sodium sulfate (J.T. Baker, Phillipsburg, N.J.). The hexane containing the extracted organochlorines was decanted off, and the procedure repeated four additional times. The decanted supernatant was dried in a sodium sulfate column, and concentrated to a volume of less than $15 \mathrm{ml}$ in a KudernaDanish evaporator (Kontes Glassware, Vineland, N.J.). The concentrated extract was then cleaned by partitioning between hexane and acetonitrile (J.T. Baker, Phillipsburg, N.J.), and the cleaned extract dried and concentrated to a volume of less than $5 \mathrm{ml}$. Cleanup of this extract was completed by passing it through a column of activated Florisil (J.T. Baker, Phillipsburg, N.J.) with a 
mobile phase of $150 \mathrm{ml}$ of hexane at a flow rate of $5 \mathrm{ml} / \mathrm{min}$. The eluate was then concentrated to a volume of less than $3 \mathrm{ml}$.

The eluate contained the PCB's and p,p-DDE present in the blubber, along with certain other organochlorines which do not absorb UV well enough for detection at the concentrations encountered in marine mammal blubber. A 25ul sample of this eluate was injected into an isocratic HPLC system to check for the presence of PCB's and/or p,p-DDE. A prepacked Lichrosorb SI 60, 5 um adsorption column (E. Merck, Darmstadt, Ger.) was used with a mobile phase of 95:5 hexane:chloroform (J.T. Baker, Phillipsburg, N.J.) at a flow rate of $1.4 \mathrm{ml} / \mathrm{min}$ and detection at $205 \mathrm{~nm}$. The eluate was then subjected to chromium trioxide (Mallinckrodt, St. Louis, Mo.) oxidation to convert the p,p-DDE to p,p-DCBP (dichlorobenzophenone), to permit its separation from PCB's present. A 25ul sample of this oxidized eluate was then injected into the HPLC system to detect the presence of PCB's and p,p-DDE. An estimate of concentrations was made by comparing peak areas to those of standards.

\section{RESULTS}

In the HPLC system used in this study, the PCB's and p,pDDE exhibit similar retention times of about $2.10 \mathrm{~min}$. This is illustrated in Figure 11 which shows the broad range of peaks of the Aroclor 1254 standard overlapping the single peak of the p,pDDE standard. In order to obtain separation, oxidation of the 
Florisil eluate containing these two substances was performed to convert $p, p-D D E$ to $p, p-D C B P$, which exhibits a longer retention time. This is shown in Figure 12. Oxidized p,p-DDE has a retention time of about $5.5 \mathrm{~min}$, the same as that exhibited by the $p, p-D C B P$ standard. Since the conversion of $p, p-D D E$ to $p, p-D C B P$ is essentially complete, and since the absorbance of the two substances was found to be approximately the same, a semiquantitative determination of the residue level of $p, p-D D E$ could be obtained from peak area comparisons of oxidized p,p-DDE with p,p-DCBP standards of known concentrations (Collins et al., 1972; Miles 1972). PCB's are unaffected by this oxidation procedure, and continue to exhibit a retention time of about 2.1 min. An approximation of the residue levels of PCB's was obtained by peak area comparisons with Aroclor 1254 standards of known concentrations.

The hexane eluate of the Florisil column contains PCB's, p,pDDE, o,p-DDE, aldrin, mirex, heptachlor, trans-nonachlor, and some o,p-DDT (Reynolds, 1969; Calambokidis et al., 1984). Other than the PCB's, DDE, and DDT, the components of this fraction do not absorb UV light well, or at all, and so are undetectable in the HPLC system used for these analyses (Dolan \& Seiber, 1977; Osselton \& Snelling, 1986). o,p-DDE and o,p-DDT usually occur in such low amounts in marine mammal blubber as to also be undetectable (Brooks, 1974; Kurtz \& Kim, 1976; Kleivane et al., 1995). Therefore, the components of this eluate that are detectable are 
total PCB's and p,p-DDE. In order to determine whether or not a sample contained detectable residues of PCB's or p,p-DDE, a portion of the Florisil eluate was injected into the system. If peaks were found, then the eluate was subjected to chromium trioxide oxidation, which would allow for the separation and detection of these two substances. Figure 13 illustrates the chromatograms obtained from a sample before and after oxidation. The pre-oxidation eluate exhibited a major peak at about 2.1 min., indicating that PCB's and/or p,p-DDE were present. Following oxidation it could be seen that this sample contained p,p-DDE, but no detectable amount of PCB's. Examples of chromatograms of oxidized Florisil eluates obtained from three additional samples are shown in Figures $14-16$. Each of these illustrates the presence of both PCB's and p,p-DDE.

Samples from a total of 55 individual marine mammals were analyzed, the results of which are listed in Tables XVI - XX. Recoveries determined from spiking samples with known amounts of p,p-DDE and Aroclor 1254 averaged $82.5 \pm 11.7 \%$ for PCB's and $85.6 \pm 9.3 \%$ for p,p-DDE. A validation of the method and determination of recovery was performed using a sample of whale blubber that had been thoroughly analyzed by the U.S. National Institute of Standards and Technology (NIST). Recoveries from this sample, SRM-1945, were $82.5 \%$ for PCB's and $81.6 \%$ for p,p-DDE. 


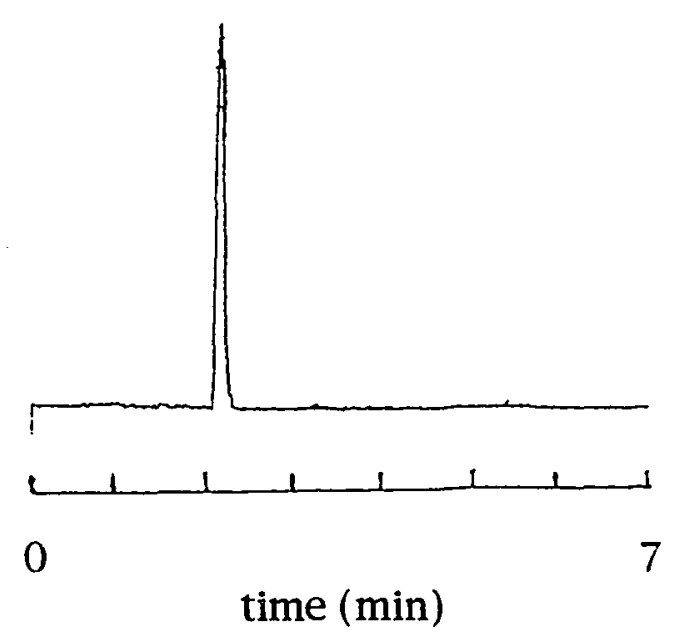

(a)

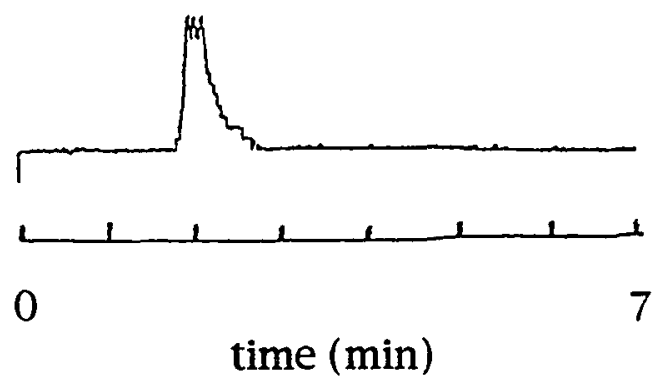

(b)

Figure 11. HPLC chromatograms of (a) p,p-DDE@ $10 \mathrm{ug} / \mathrm{g}$. and Aroclor $1254 @ 100$ ug/g. 


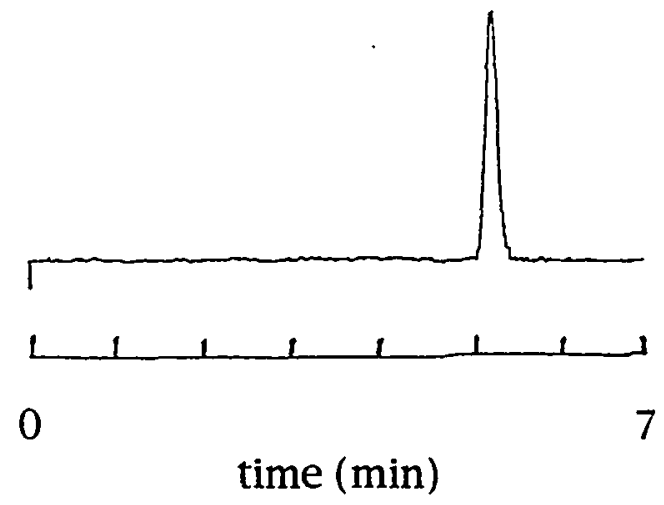

(a)

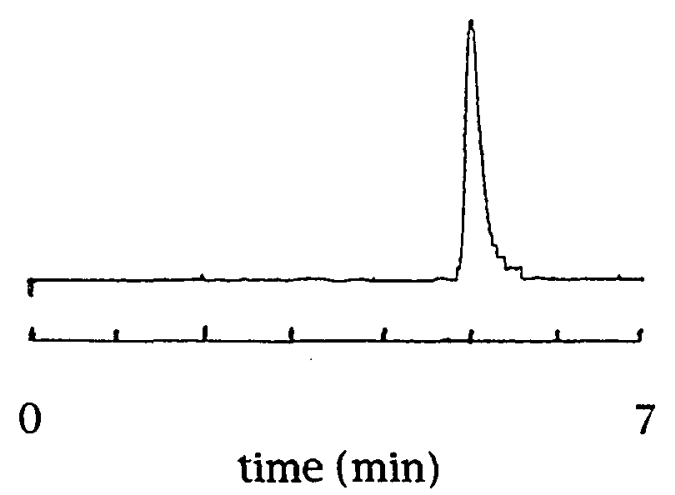

(b)

Figure 12. HPLC chromatograms of (a) oxidized p,p-DDE@ 10 ug/g, and (b) p,p-DCBP @ $10 \mathrm{ug} / \mathrm{g}$. 


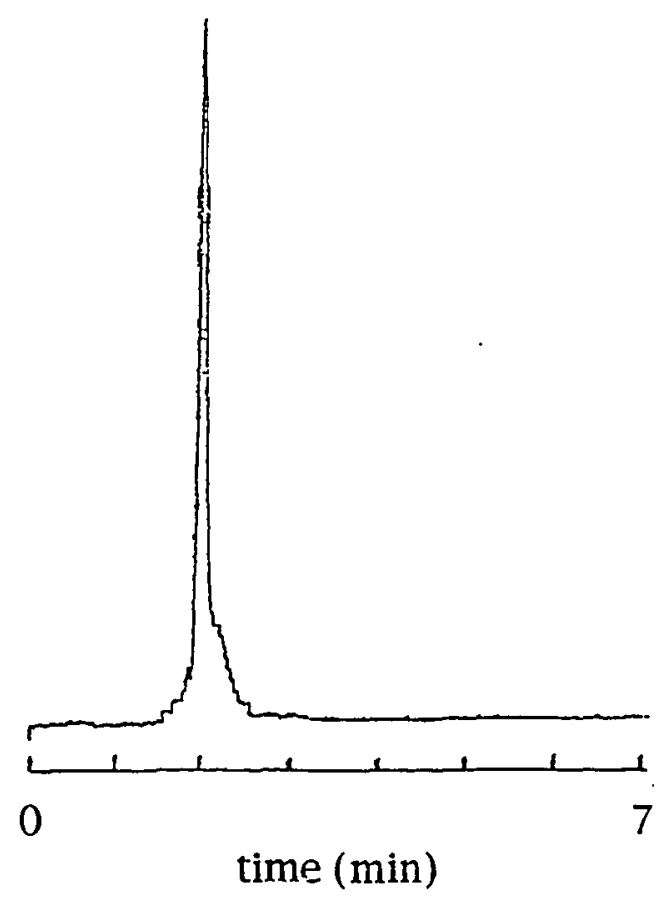

(a)

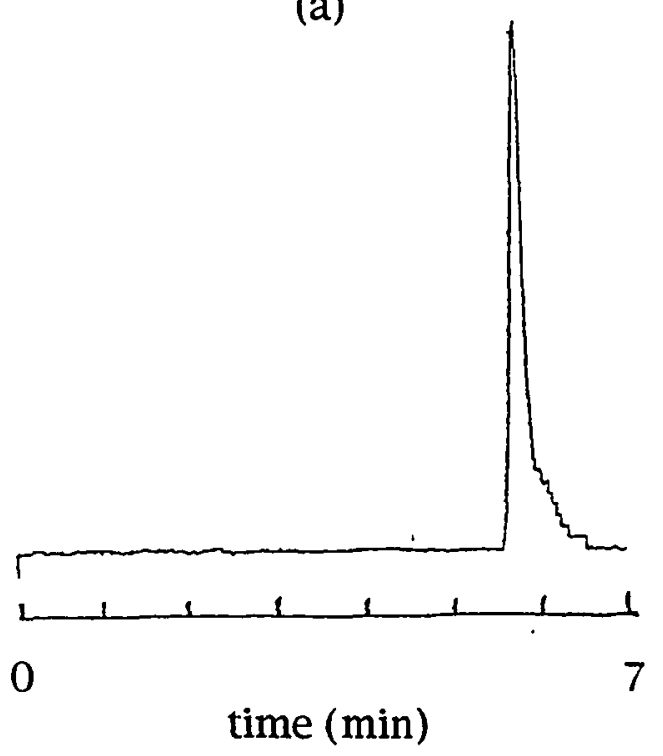

(b)

Figure 13. HPLC chromatograms of the cleaned extract of California sea lion (Zalophus californianus)

(a) before oxidation, and (b) after oxidation. 


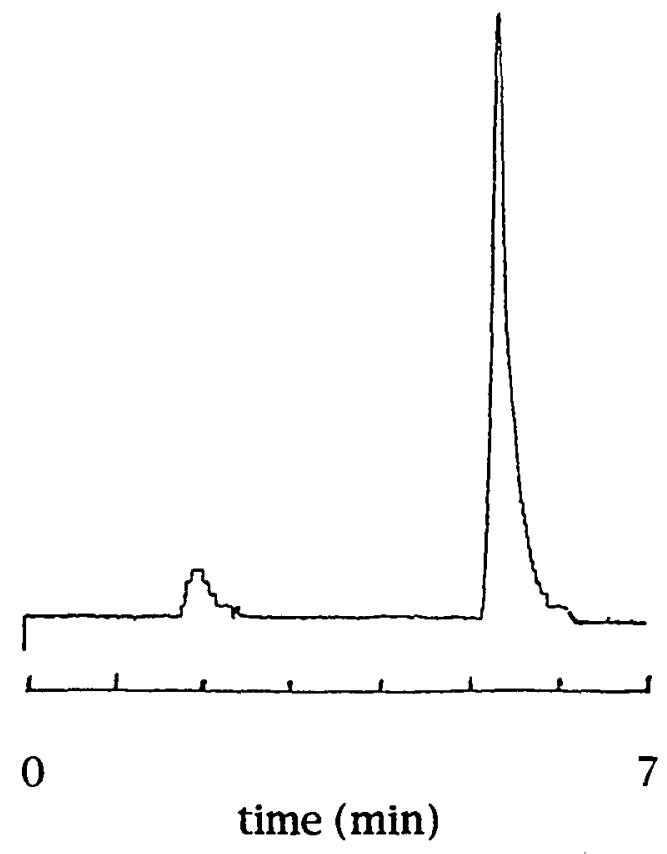

Figure 14. HPLC chromatogram of the oxidized extract of harbor seal (Phoca vitulina).

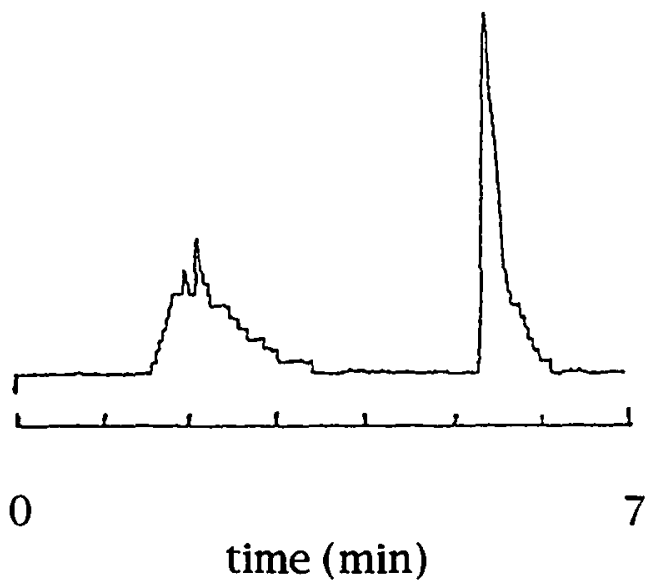

Figure 15. HPLC chromatogram of the oxidized extract of harbor porpoise (Phocoena phocoena). 


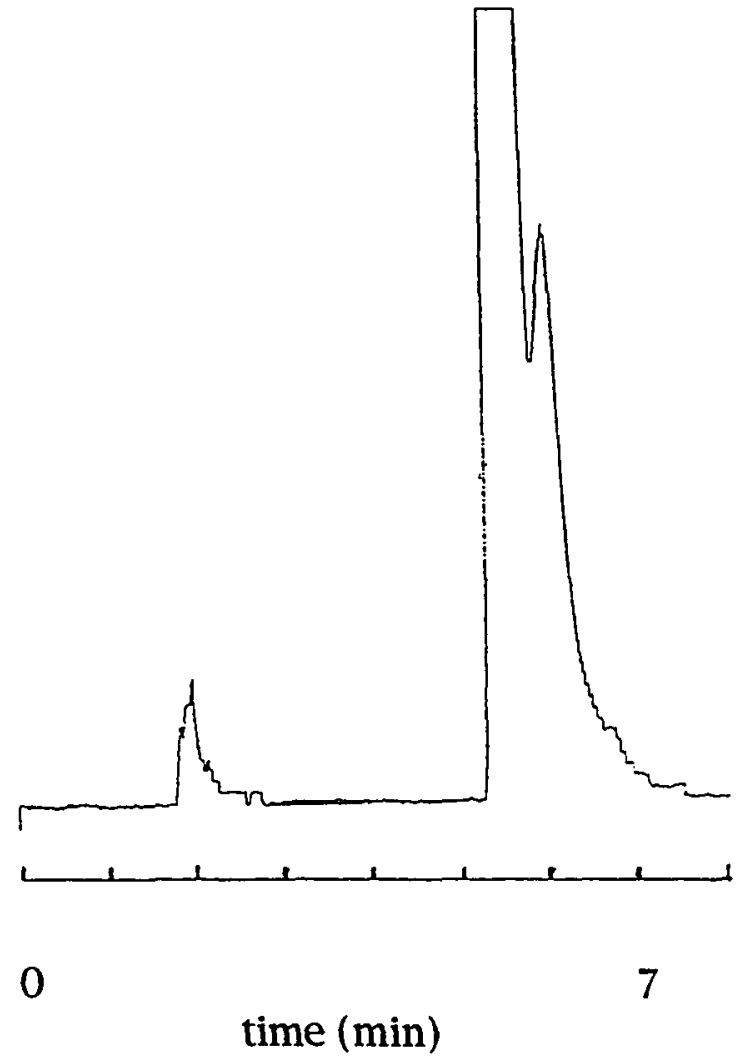

Figure 16. HPLC chromatogram of the oxidized extract of killer whale ( 
TABLE XVI

Concentrations (ppm - wet wt.) of Total PCB's and p,p-DDE Found in the Blubber of the Harbor Seal (Phoca vitulina). $\mathrm{ND}=$ none detected

Date $\underline{\text { Location }}$ Length $\underline{\text { Sex }}$ p,p-DDE PCB's $\underline{\text { PCB/DDE }}$

Adults

\begin{tabular}{lllcccc}
\hline $5 / 10 / 91$ & N. Ore. & $156 \mathrm{~cm}$ & F & 0.4 & ND & 0 \\
$2 / 24 / 92$ & N. Ore. & $176 \mathrm{~cm}$ & M & 1.0 & ND & 0 \\
$10 / 10 / 95$ N. Ore. & $133 \mathrm{~cm}$ & F & 5.8 & 1.7 & 0.29 \\
& & Mean: & 2.4 & 0.6 &
\end{tabular}

Juveniles

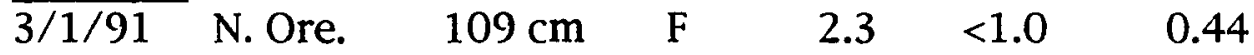

2/23/92 N. Ore. $\quad 110 \mathrm{~cm} \quad \mathrm{~F} \quad 0.8 \quad$ ND $\quad 0$

$\begin{array}{lllllll}2 / 24 / 92 & \text { N. Ore. } & 102 \mathrm{~cm} & \mathrm{M} & 0.7 & <1.1 & 1.58\end{array}$

4/10/95 N. Ore. $\quad 110 \mathrm{~cm} \quad \mathrm{M} \quad 2.2<1.4 \quad 0.64$

$8 / 11 / 95 \quad$ N. Ore. $\quad 109 \mathrm{~cm} \quad$ F $\quad 6.2<1.3 \quad 0.21$

Mean: $\quad 2.4 \quad 1.0$

Pups

\begin{tabular}{rrrrrrr}
\hline $4 / 18 / 95$ & N. Ore. & $79 \mathrm{~cm}$ & $M$ & 1.0 & ND & 0 \\
$7 / 15 / 95$ & N. Ore. & $72 \mathrm{~cm}$ & F & 12.5 & 6.1 & 0.49 \\
& & & Mean: & 6.8 & 3.1 & \\
& & & & & \\
& & & &
\end{tabular}


TABLE XVII

Concentrations (ppm - wet wt.) of Total PCB's and p,p-DDE Found in the Blubber of Other Pinnipeds.

$$
\mathrm{ND}=\text { none detected }
$$

Date Location Length Sex p,p-DDE PCB's

California Sea Lion (Zalophus californianus)

\begin{tabular}{llllrr}
$\frac{\text { Adults }}{1988}$ & S. Calif. & $260 \mathrm{~cm}$ & $\mathrm{M}$ & 12.8 & ND \\
$2 / 26 / 91$ & N. Ore. & $180 \mathrm{~cm}$ & $\mathrm{M}$ & 15.4 & $<1.3$ \\
$2 / 25 / 92$ & N. Ore. & $190 \mathrm{~cm}$ & $\mathrm{M}$ & 10.6 & $<2.0$ \\
$2 / 28 / 92$ & N. Ore. & $187 \mathrm{~cm}$ & $\mathrm{M}$ & 7.2 & $<1.1$ \\
$12 / 6 / 95$ & N. Ore. & $260 \mathrm{~cm}$ & $\mathrm{M}$ & 9.3 & $\mathrm{ND}$ \\
& & & Mean: & 11.1 & 0.9 \\
$\frac{\text { Juvenile }}{2 / 25 / 92}$ & N. Ore. & $140 \mathrm{~cm}$ & M & 3.2 & 1.0 \\
& \multicolumn{4}{c}{ Steller's Sea Lion (Eumetopias jubatus) }
\end{tabular}

Adults

$\begin{array}{llllll}4 / 4 / 91 & \text { N. Ore. } & 222 \mathrm{~cm} & F & 31.3 & 8.7\end{array}$

$4 / 15 / 91 \quad$ N. Ore. $\quad 228 \mathrm{~cm} \quad$ F $\quad 1.7 \quad<1.1$

Northern Elephant Seal (Mirounga angustirostris)

Juvenile

$\begin{array}{llllll}7 / 5 / 95 & \text { N. Ore. } & 142 \mathrm{~cm} & F & 1.1 & \text { ND }\end{array}$ 
TABLE XVIII

Concentrations (ppm - wet wt.) of Total PCB's and p,p-DDE Found in the Blubber of the Harbor Porpoise

(Phocoena phocoena).

$\mathrm{ND}=$ none detected

Date Location Length $\underline{\text { Sex }}$ p,p-DDE $\underline{\text { PCB's }} \underline{\text { PCB/DDE }}$

Adults

$\begin{array}{lllllll}4 / 15 / 95 & \text { N. Ore. } & 158 \mathrm{~cm} & \mathrm{~F} & 1.8 & <1.6 & 0.89\end{array}$

6/21/95 N. Ore. $154 \mathrm{~cm} \quad \mathrm{M} \quad 1.8 \quad$ ND $\quad 0$

10/27/95 N. Ore. $\quad 162 \mathrm{~cm} \quad$ M $\quad 8.5 \quad<1.2 \quad 0.14$

$12 / 11 / 95$ N. Ore. $\quad 178 \mathrm{~cm} \quad$ F $\quad 1.1 \quad$ ND $\quad 0$

Juveniles

Mean: $\quad 3.3 \quad 0.7$

9/29/92 N. Ore. $\quad 123 \mathrm{~cm} \quad M \quad 3.0 \quad<0.5 \quad 0.17$

$\begin{array}{lllllll}5 / 6 / 93 & \text { N. Ore. } & 148 \mathrm{~cm} & \mathrm{M} & 9.4 & 13.2 & 1.40\end{array}$

4/11/94 N. Ore. $\quad 145 \mathrm{~cm} \quad$ M $\quad 4.5 \quad 3.0 \quad 0.67$

$4 / 15 / 95 \quad$ N. Ore. $\quad 138 \mathrm{~cm} \quad$ F $\quad 5.0 \quad 24.3 \quad 4.86$

$\begin{array}{llllll}1 / 13 / 96 & \text { N. Ore. } \quad 121 \mathrm{~cm} & \mathrm{M} & 3.0 & <0.8 & 0.27\end{array}$

Mean: $\quad 5.0 \quad 8.4$

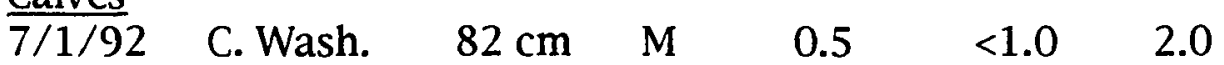

$7 / 23 / 95 \quad$ N. Ore. $\quad 96 \mathrm{~cm} \quad$ M $\quad 0.5 \quad$ ND $\quad 0$

Fetus

$7 / 11 / 95$ N. Ore.

$4.1<1.2 \quad 0.29$

Total Mean: $\quad 3.6 \quad 3.9$ 


\section{TABLE XIX}

Concentrations (ppm - wet wt.) of Total PCB's and p,p-DDE Found in the Blubber of Other Cetaceans and Carnivores.

$$
\mathrm{ND}=\text { none detected }
$$

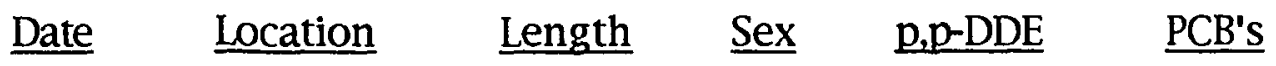

$\underline{\text { Pacific Ocean }}$

Adults

Common Dolphin (Delphinus delphis)

$5 / 6 / 93$

N. Ore.

$191 \mathrm{~cm}$

F

53.9

6.1

1994

S. Calif.

3.4

ND

Juvenile

$1 / 13 / 96$

N. Ore.

M

11.5

$<1.3$

Striped Dolphin (Stenella coeruleoalba)

$\underline{\text { Adult }}$

4/15/95

N. Ore.

37.6

5.9

Bottlenose Dolphin(Tursiops truncatus)

Calf

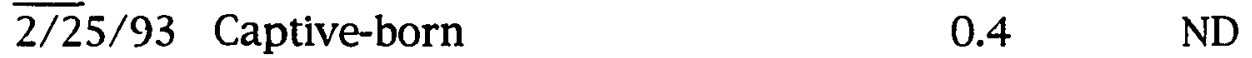

Dall's Porpoise (Phocoenoides dalli)

Fetus

$4 / 10 / 95 \quad$ N. Ore.

1.6

ND 
Risso's Dolphin (Grampus griseus)

Calf - newborn

$\begin{array}{llllll}10 / 5 / 95 & \text { N. Ore. } & 187 \mathrm{~cm} & \mathrm{M} & 44.5 & 18.6\end{array}$

False Killer Whale (Pseudorca crassidens)

$\underline{\text { Adult }- \text { wild-caught (1988) - captive }}$

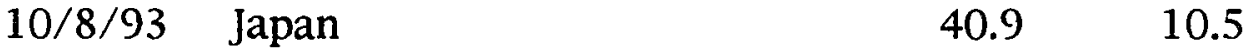

Stejneger's Beaked Whale (Mesoplodon stejnegeri)

Calf - newborn

$\begin{array}{llllll}10 / 95 & \text { C. Ore. } & 255 \mathrm{~cm} & \text { M } & 3.8 & <0.9\end{array}$

Minke Whale (Balaenoptera acutorostrata)

Fetus

$\overline{5 / 25 / 93}$ N. Ore. $\quad 180 \mathrm{~cm} \quad \mathrm{M} \quad<0.1 \quad<0.6$

Walrus (Odobenus rosmarus)

Adult - captive

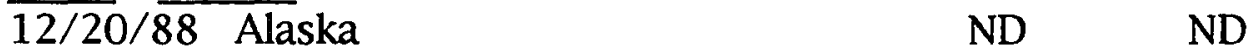

Polar Bear (Ursus maritimus)

Adult - captive

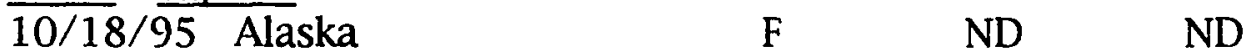


Atlantic Ocean

Bottlenose Dolphin (Tursiops truncatus)

Adults

9/7/91 W. Flor.

8.29 .9

$5 / 3 / 92$

E. Flor.

1.7

1.3

1993

E. Flor.

1.4

7.2

Short-Finned Pilot Whale (Globicephala macrorhynchus)

Adults

$12 / 22 / 88$ New York

$17.2 \quad 15.2$

1993

E. Flor.

2.5

1.4

Commerson's Dolphin (Cephalorhynchus commersonii)

Adult - wild-caught - captive

1983

Patagonia

M

8.5

12.5

Calf

\begin{tabular}{llll}
\hline 5/7/91 Captive-born & 1.6 & 7.0
\end{tabular}

Pygmy Sperm Whale ( $\underline{\text { Kogia breviceps) }}$

Adults

4/20/92

E. Flor.

1.8

4.5

$8 / 31 / 92$

E. Flor.

M

6.6

1.3 


\section{TABLE XX}

Concentrations (ppm - wet wt.) of Total PCB's and p,p-DDE Found in the Blubber of the Killer Whale (Orcinus orca)

$\underline{\text { Date }} \underline{\text { Location }} \underline{\text { Length }} \underline{\text { Sex }}$ p,p-DDE $\underline{\text { PCB's }}$

Adult

$\begin{array}{llllll}4 / 13 / 96 & \text { N. Ore. } & 622 \mathrm{~cm} & F & 494 & 276\end{array}$

Calves - newborn

7/24/93 C. Ore.

$235 \mathrm{~cm} \quad \mathrm{M}$

151

19.5

$5 / 13 / 95$

C. Ore.

$212 \mathrm{~cm} \quad \mathrm{~F}$

519

117 


\section{DISCUSSION}

Organochlorine residues have been used to delineate the primary geographical habitat of marine mammals (Winn \& Scott, 1978; Gaskin et al., 1982). Following this, general inferences of location based on such residues can be made. For example, eight adult animals from the Atlantic Ocean were examined in this study, while eighteen adults from the Pacific Ocean were analyzed. The Atlantic specimens showed an average PCB concentration of $6.7 \pm 5.4 \mathrm{ppm}$, while those from the Pacific had a mean level of $2.3 \pm 3.2 \mathrm{ppm}$. This probably reflects the greater industrialization and concomitant high PCB pollution of the lands bordering the Atlantic, and is a generally reported occurrrence (Aguilar \& Borrell, 1988; Law et al., 1989; Luckas et al., 1990;

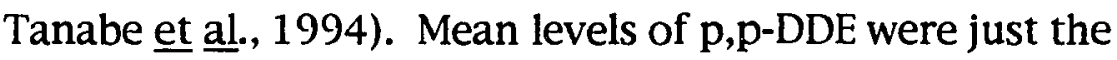
reverse. Atlantic animals exhibited a mean concentration of $6.0 \pm 5.4 \mathrm{ppm}$, while Pacific adults averaged $13.6 \pm 16.1 \mathrm{ppm}$. This probably reflects less industrialization and the greater use of chlorinated hydrocarbons in agriculture and forestry in the western part of North America and Asia. In examining individual animals from the Atlantic, the high residue levels found in the stranded pilot whale (Globicephala macrorhynchus) from New York as compared with the one from Florida possibly reflect a difference in pollution levels in the two marine environments. There is a difference between bottlenose dolphins (Tursiops truncatus) from west Florida compared with east Florida. Pygmy 
sperm whales (Kogia breviceps) stranded in Florida exhibited relatively low residue levels, but PCB levels were higher than DDE levels in one, with the situation reversed in the other. Since both animals were adult males, different feeding areas might be indicated. One adult Commerson's dolphin (Cephalorhynchus commersonii) originated off the coast of Patagonia. Its residue levels of $12.5 \mathrm{ppm}$ for PCB's and $8.5 \mathrm{ppm}$ for p,p-DDE suggest the possibility of its feeding extensively in an industrialized region.

Regional differences in geographical distribution are also reflected by comparative levels of PCB's and p,p-DDE in adult Pacific animals. The waters off southern California have been heavily contaminated with DDT and its metabolites, as a result of sewer discharges and agricultural usage (MacGregor, 1974). Marine mammals feeding primarily in this region should exhibit relatively higher levels of $\mathrm{p}, \mathrm{p}$-DDE. One of the common dolphins (Delphinus delphis) and the striped dolphin (tenella coeruleoalba) stranded in Oregon probably reflect this, since these species have a more southern range and are uncommon along this coastline (Rice, 1977). Similarly, California sea lions (Zalophus californianus) examined in this study exhibited consistently higher residue levels of p,p-DDE, as compared with those of PCB's. Males of this species move north along the Pacific coast after the breeding season, hauling out at various locations during the winter months (Mate 1978). All the animals examined in this study were males, and all but one were stranded in northern 
Oregon. The range of $\mathrm{p}, \mathrm{p}-\mathrm{DDE}$ residues in these animals probably reflects duration of feeding time in more southerly California waters. The two Steller's sea lions (Eumetopias jubatus) sampled may also reflect differing feeding areas and ranges, with the animal exhibiting the much higher $\mathrm{p}, \mathrm{p}$-DDE residues possibly ranging further south. Since both animals were females, differences in reproductive status may also account for differences in residue levels. The offshore feeding and deepwater habits probably account for the low residues found in the northern elephant seal (Mirounga angustirostris), while the higher levels seen in the false killer whale (Pseudorca crassidens) may reflect its origin in the waters off Japan. The only Pacific bottlenose dolphin examined was a captive-born calf, while the walrus (Odobenus rosmarus) and polar bear (Ursus maritimus) were long-time zoo animals. The very low or undetectable residues of PCB's and p,p-DDE in these animals reflect this captive history. These samples provided useful controls for this study, as did a sample of fat from organically-raised cattle which also exhibited no detectable residues of PCB's or p,p-DDE. The low mean concentrations found in adult harbor porpoises (Phocoena phocoena) and harbor seals (Phoca vitulina) illustrate the relatively less polluted primary feeding areas of these animals along the Oregon and outer Washington coasts (Calambokidis et al., 1984; Calambokidis \& Francis, 1994). Higher levels of PCB's 
were found in harbor seals and harbor porpoises in Puget Sound (Calambokidis et al., 1984; Calambokidis \& Barlow,1991).

With larger samplings of animals, concentrations and/or ratios can be used to delineate populations and examine movements (Aguilar, 1987). Calambokidis \& Barlow (1991) used the ratio of $\mathrm{PCB} / \mathrm{DDE}$ to describe discrete populations of harbor porpoises from Washington, Oregon and California. A higher $\mathrm{PCB} / \mathrm{DDE}$ ratio was characteristic of porpoises from Puget Sound and northern Washington, whereas, the ratio steadily decreased from southern Washington and Oregon to California and the Mexico border. Using their calculations, three of the animals in Table XVIII (ratios 1.4, 2.0, \& 4.86) appear to have had feeding ranges in northern Washington, while two (ratios $0.67 \& 0.89$ ) probably fed near the mouth of the Columbia River or off the Oregon coast. The other specimens are possibly California animals, although those with no PCB residues detected may have had yet a different range than the others (see below).

If these calculations of Calambokidis \& Barlow (1991) are extended to harbor seals, it first becomes apparent that ratios (Table XVI) show much less variation, possibly due to greater site fidelity in this species (Reeves et al., 1992). One animal (ratio 1.58) would fit with having ranged primarily in northern Washington, while three others (ratios $0.44,0.49, \& 0.64$ ) were probably animals from just north of the Columbia River. Since PCB pollution was documented in the Columbia River in the 
1970 's, those harbor seals with ratios 0.21 and 0.29 were probably residents of the estuary of this river (Claeys et al., 1975), compared with those animals with no PCB residues detected which may very well have been feeding mainly along the Oregon coast where PCB contamination was practically nonexistent. The same could be true of the three harbor porpoises exhibiting no detectable PCB residues. Because of the use of a different method of detection and quantification in this study, exact correlation with ratios determined by more traditional GC methods probably cannot be made. However, the general patterns found in previous investigations can be used to compare with the HPLC results to approximate the primary residence areas of the harbor porpoises and harbor seals examined.

Residue levels obtained in this study generally fall within the range of those reported in the literature for marine mammals (Calambokidis et al., 1984; Luckas et al., 1990; Calambokidis \& Barlow, 1991). Reported levels of PCB's and p,p-DDE tend to be higher in nearshore animals feeding in more industrialized and polluted regions of the world, such as the Mediterranean and North Seas and the Gulf of St. Lawrence (Amico et al., 1979; Tanabe, 1988; Beland et al., 1992; Aguilar \& Borrell, 1994; Olsson et al., 1994; O'Shea \& Brownell, 1994). In this study, PCB and p,pDDE loads averaged $4.2 \pm 5.2 \mathrm{ppm}$ and $20.8 \pm 17.0 \mathrm{ppm}$ respectively in adult animals from southern California, Japan, and New York. 
In contrast, $\mathrm{PCB}$ mean concentration was $3.3 \pm 4.0 \mathrm{ppm}$ and $\mathrm{p}, \mathrm{p}$-DDE mean concentration was $5.3 \pm 7.5 \mathrm{ppm}$ for adult animals from other areas. Mean PCB concentrations were not significantly different between more polluted and less polluted areas, probably reflecting the fact that areas considered less polluted in this study have PCB "hot spots", such as Puget Sound in Washington (Calambokidis et al., 1984). The global distribution of PCB's may also play a part in this lack of significant difference. DDE mean concentration was significantly higher in animals from areas considered to be more polluted with DDT. Since most of these animals are generally found off southern California and Mexico, areas of high DDT input and contamination in the past, the mean level of this pollutant reflects the contaminated habitat of these animals. Although the number of offshore animals examined was very small, they exhibited relatively low residue levels.

The use of organochlorine burdens to delineate primary ranges can be confounded by differences in age and sex of the animals sampled. It has been shown that for many species of marine mammals pollutant loads in blubber continue to increase with age in males, while in females loads increase with age until reproductive maturity, when levels decrease (Addison \& Smith, 1974; Donkin et al., 1981; Calambokidis et al., 1984; Aguilar \& Borrell, 1988). This decrease in females is thought to result from transfer of pollutants to offspring via the placenta and/or lactation (Addison \& Brodie, 1977; Gaskin, 1982; Wagemann \& 
Muir, 1984; Subramanian et al., 1988). The use of ratios rather than absolute concentrations helps to equalize the comparison between males and females, since ratios should not change greatly with placental or lactational transfer in females even though the concentrations are less than those found in males (Aguilar, 1987). Due to the low number of samples examined for each species, and the lack of more than an approximate age determination, it was not possible in this study to illustrate changes in PCB and p,p-DDE loads with age, although the adult California sea lions examined all exhibited higher p,p-DDE levels than did the one juvenile. No clear-cut pattern was found in either the harbor seals or harbor porpoises, even though residue levels tended to be higher in the younger animals of both species. This presumably could be due to the acquiring of a high load via placental and/or lactational transfer with a decrease occurring after weaning. If these animals stay in areas along the Oregon and Washington coasts where pollution is relatively low, then metabolism and excretion of PCB's and p,p-DDE may be greater than uptake from their environment, and this, coupled with the rapid deposition of fat in younger animals, may result in a gradual decrease in concentrations with growth. The number of examined samples of other species were too few to derive any conclusions regarding age and sex differences in pollutant loads.

The decrease in organochlorine residue levels in the blubber of female marine mammals is thought to be associated with the 
mobilization of these contaminants from the blubber during pregnancy and lactation, and the transfer of these substances to the offspring across the placenta and in the milk (Aguilar \& Borrell, 1988; Subramanian et al., 1988). Newborns and sucklings, especially firstborns, should therefore exhibit high concentrations, as was shown in this study. The highest residues found in the harbor seals occurred in a newborn pup. The harbor porpoise fetus sampled had relatively high levels, lending support to the hypothesis that placental transfer may be greater in this species than in many others (Duinker \& Hillebrand, 1979; Donkin et al., 1981). The levels of PCB's and p,p-DDE were somewhat higher in the newborn beaked whale calf (Mesoplodon stejnegeri) than those most recently reported for adults in other areas of the world (de Kock et al., 1994; Kemper et al., 1994). The newborn calf of the Risso's dolphin (Grampus griseus) was found to contain quite high levels, indicating that in this species placental transfer may also be important. This conclusion is only tentative, as reports of contaminant loads in adult Risso's dolphins are practically non-existent (Calambokidis \& Francis, 1994). The Commerson's dolphin calf that was examined was born to a wildcaught female that had been in captivity for a number of years. This calf had higher levels of contaminants than the bottlenose dolphin captive-born calf examined, with greater amounts of PCB's than of $p, p-D D E$. This reflects the situation found in the adult male examined, and indicates that transfer of stored 
organochlorines from mother to offspring can still occur years after the female has been removed from a polluted environment. This may reflect a very low rate of metabolism and excretion in this species.

The highest levels of PCB's and p,p-DDE found in this study occurred in stranded killer whales (Orcinus orca) (Table XX). Because of this they were not included in the calculations of means mentioned previously. A newborn calf stranded on the central Oregon coast in 1995 had levels of 117 ppm of PCB's and $519 \mathrm{ppm}$ of p,p-DDE. Lower levels were found in a newborn calf stranded in the same area in 1993. These values indicate a relatively higher level of placental transfer of these substances than that found in many other species, a phenomenon possibly shared with the harbor porpoise and Risso's dolphin. High levels in adult males from the Pacific Northwest coasts have been reported previously, i.e., 41 - 140 ppm PCB's and 66 - 514 ppm total DDT (Calambokidis et al., 1990; Muir et al., 1991). Analysis of the blubber of an adult female killer whale, $622 \mathrm{~cm}$ in length, that had stranded on the northern Oregon coast in 1996, also revealed very high levels of contaminants - $276 \mathrm{ppm}$ of PCB's and $494 \mathrm{ppm}$ of $\mathrm{p}, \mathrm{p}$-DDE. The magnitude of these values and the greater concentration of $\mathrm{p}, \mathrm{p}-\mathrm{DDE}$ as compared with PCB's is similar to that reported for the males referred to previously. All three of the killer whales examined in this study were thought to be transient animals which feed on other marine mammals, as 
opposed to fish-eating resident types. This position at the very top of the food chain along with their migratory habits helps to explain the high contaminant levels in these animals. In addition, the metabolic capabilities of these animals to rid themselves of organochlorines may be very poor, as has been found in other odontocetes (Tanabe et al., 1988). A conclusion to be drawn from these findings is that although organochlorine pollutant levels have declined in many marine species found off the western coast of North America, these contaminants are still present in the environment where many of these animals live and feed. They are still being accumulated and passed on in high concentrations to species high on the food chain, such as the killer whale. It is obvious that the marine environment is significantly polluted and impacting the species living in this environment. The long-term effects of this pollution on marine mammals inhabiting these areas are still unknown, but are certainly cause for concern. 


\section{CHAPTER V}

\section{CONCLUSIONS}

This study showed that HPLC can be used to screen marine mammal blubber for the presence of PCB's and p,p-DDE, the two most commonly found organochlorine pollutants in such tissue. Chromium trioxide oxidation of cleaned extracts to convert $\mathrm{p}, \mathrm{p}$-DDE to the more polar p,p-DCBP allowed for the separation of the PCB's and p,p-DDE on an HPLC adsorption column. The use of isocratic conditions with a hexane:chloroform mobile phase and an ultraviolet detector monitoring the eluate flow at $205 \mathrm{~nm}$ permitted the detection and semiquantitative determination of the two residues. Recoveries and concentration values obtained were within the range of those reported in the literature. HPLC can therefore provide a fast and simple alternative to more traditional methods of determining the levels of PCB's and p,p-DDE in marine mammal blubber.

The screening performed using this technique illustrated that geographical differences in residue loads exist in these animals, reflecting different primary ranges and feeding areas. The ratio $\mathrm{PCB} / \mathrm{DDE}$ provides an indication of such ranges and feeding areas in members of the same species, indicating the possibility of detecting discrete populations. No definite 
conclusions could be drawn regarding the relationship of pollutant loads with age, sex, or reproductive status. The occurrence of placental transfer of organochlorines was observed with elevated levels found in a fetus and in newborn calves, especially in killer whale calves. Finally, it is apparent that certain marine mammals, particularly transient killer whales, are carrying extremely high loads of PCB's and p,p-DDE, loads that have been correlated with severe chronic effects in other species of marine mammals. Organochlorine pollution is, therefore, still a problem in these migratory, higher trophic level predators, indicating that their environment is still being impacted by these persistent anthropogenic contaminants. 


\title{
APPENDIX A \\ CLASSIFICATION OF RECENT MARINE MAMMALS
}

Order Cetacea

Suborder Mysticeti

Family Balaenidae

Balaena mysticetus

Eubalaena glacialis

Eubalaena australis

Family Neobalaenidae

Caperea marginata

Family Eschrichtiidae

Eschrichtius robustus

Family Balaenopteridae

Balaenoptera acutorostrata

Balaenoptera borealis

Balaenoptera edeni

Balaenoptera musculus

Balaenoptera physalus

Megaptera novaeangliae

Suborder Odontoceti

Family Delphinidae

Cephalorhynchus commersonii

Cephalorhynchus eutropia

Cepphalorhynchus heavisidii

Cephalorhynchus hectori

Delphinus delphis

Feresa attenuata

Globicephala macrorhynchus

\author{
bowhead \\ northern right \\ whale \\ southern right \\ whale \\ pygmy right whale \\ grey whale \\ minke whale \\ sei whale \\ Bryde's whale \\ blue whale \\ fin whale \\ humpback whale
}

Commerson's
dolphin
black dolphin
Heaviside's dolphin
Hector's dolphin
common dolphin
pygmy killer whale
short-finned pilot
whale


Globicephala melaena

Grampus griseus

Lagenodelphis hosei

Lagenorhynchus acutus

Lagenorhynchus albirostris

Lagenorhynchus australis

Lagenorhynchus cruciger

Lagenorhynchus obliquidens

Lagenorhynchus obscurus

Lissodelphis borealis

Lissodelphis peronii

Orcaella brevirostris

Orcinus orca

Peponocephala electra

Pseudorca crassidens

Sotalia fluviatilis

Sousa chinensis

Sousa teuszii

Stenella attenuata

Stenella clymene

Stenella coeruleoalba

Stenella frontalis

Stenella longirostris

Steno bredanensis

Tursiops truncatus

Family Monodontidae

Delphinapterus leucas

Monodon monoceros long-finned pilot whale

Risso's dolphin

Fraser's dolphin

Atlantic whiteside dolphin

white-beaked dolphin

Peale's dolphin hourglass dolphin

Pacific white-sided dolphin dusky dolphin northern right whale dolphin southern right whale dolphin Irrawaddy dolphin killer whale melon-headed whale

false killer whale tucuxi Indo-Pacific humpbacked dolphin Atlantic humpbacked dolphin bridled dolphin Atlantic spinner dolphin striped dolphin spotted dolphin spinner dolphin rough-toothed dolphin bottlenose dolphin

beluga narwhal 
Family Phocoenidae

Australophocaena dioptrica Neophocaena phocaenoides Phocoena phocoena

Phocoena sinus

Phocoena spinipinnis

Phocoenoides dalli

Family Physeteridae

Kogia breviceps

Kogia simus

Physeter catodon

Family Platanistidae

Inia geoffrensis

Lipotes vexillifer

Platanista gangetica

Platanista minor

Pontoporia blainvillei

Family Ziphiidae

Berardius arnuxii

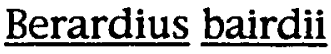

Hyperoodon ampullatus

Hyperoodon planifrons

Indopacetus pacificus

Mesoplodon bidens

Mesoplodon bowdoini

Mesoplodon carlhubbsi spectacled porpoise finless porpoise harbor porpoise gulf porpoise (vaquita) Burmeister's porpoise Dall's porpoise

pygmy sperm whale dwarf sperm whale sperm whale

Amazon porpoise (boutu) white fin dolphin Ganges dolphin Indus dolphin La Plata dolphin (franciscana)

Arnoux's beaked whale Baird's beaked whale northern bottlenose whale southern bottlenose whale Indo-Pacific beaked whale Sowerby's beaked whale Andrew's beaked whale

Hubb's beaked whale 
Mesoplodon densirostris

Mesoplodon europaeus

Mesoplodon ginkgodens

Mesoplodon grayi

Mesoplodon hectori

Mesoplodon layardii

Mesoplodon mirus

Mesoplodon peruvianus

Mesoplodon stejnegeri

Tasmacetus shepherdi

Ziphius cavirostris
Blainville's beaked whale

Gervais' beaked whale ginkgo-toothed beaked whale Gray's beaked whale

Hector's beaked whale strap-toothed whale True's beaked whale Peruvian beaked whale Stejneger's beaked whale

Shepherd's beaked whale

Cuvier's beaked whale

Order Sirenia

Family Dugongidae

Dugong dugon

Hydrodamalis gigas

Family Trichechidae

Trichechus inunguis

Trichechus manatus

Trichechus senegalensis

dugong

Steller's sea cow

Amazon manatee Caribbean manatee African manatee 
Order Carnivora

Suborder Caniformia

Family Mustelidae

Enhydra lutris

Family Ursidae

Ursus maritimus $\quad$ polar bear

Family Odobenidae

Odobenus rosmarus walrus

Family Otariidae

Arctocephalus australis

Arctocephalus fosteri

Arctocephalus galapagoensis

Arctocephalus gazella

Arctocephalus philippii

Arctocephalus pusillus

Arctocephalus townsendi

Arctocephalus tropicalis

Callorhinus ursinus

Eumetopias jubatus

Neophoca cinerea

Otaria byronia

Phocarctos hookeri

Zalophus californianus

Family Phocidae

Cystophora cristata

Erignathus barbatus

Halichoerus grypus

Hydrurga leptonyx

Leptonychotes weddellii

Lobodon carcinophagus

South American fur seal

New Zealand fur seal

Galapagos fur seal

Antarctic fur seal

Juan Fernandez fur seal

Afro-Australian fur seal

Guadalupe fur seal

Subantarctic fur seal

northern fur seal

Steller's sea lion

Australian sea lion

South American sea lion

New Zealand sea

lion

California sea lion

hooded seal

bearded seal

grey seal

leopard seal

Weddell seal

crabeater seal 
Mirounga angustirostris

Mirounga leonina

Monachus monachus

Monachus schauinslandi

Monachus tropicalis

Ommatophoca rossii

Phoca caspica

Phoca fasciata

Phoca groenlandica

Phoca hispida

Phoca largha

Phoca sibirica

Phoca vitulina northern elephant

seal

southern elephant

seal

Mediterranean

monk seal

Hawaiian monk

seal

Caribbean monk seal

Ross seal

Caspian seal

ribbon seal

harp seal

ringed seal

spotted seal

Baikal seal

harbor seal

Sources: Corbet \& Hill (1986); Wilson \& Reeder (1993).

Note: Some authors place the families Otariidae, Odobenidae, and Phocidae in a separate order, Pinnipedia (see Hall, 1981). 
APPENDIX B

\section{STEPWISE EXPERIMENTAL PROTOCOL}

\section{Extraction of Organochlorines}

1. Thaw blubber sample at room temperature for $30 \mathrm{~min}$.

2. Remove the skin from the outer surface and the muscle from the inner surface.

3. Cut off a piece weighing about $7 \mathrm{~g}$, and record the weight.

4. Cut this piece into cubes of about $1 \mathrm{~cm}$ on a side.

5. Place the cubes into a mortar $(8 \mathrm{~cm}$ i.d.), add $10 \mathrm{~g}$ of sand (acid-washed), and $30 \mathrm{ml}$ of hexane (reagent grade).

6. Grind the mixture with a pestle for $1 \mathrm{~min}$., then place the mortar in a shaker water bath set at $65^{\circ} \mathrm{C}$ for $10 \mathrm{~min}$. to soften the fat.

7. Remove the mortar from the water bath, add $10 \mathrm{~g}$ of sodium sulfate ( $\mathrm{Na}_{2} \mathrm{SO}_{4}$, anhydrous), and grind for $1 \mathrm{~min}$.

8. Decant the supernatant through a $12 \mathrm{~cm}$ Buchner funnel fitted with two sheets of Whatman \#1 filter paper into a suction flask or Erlenmeyer flask.

9. Add another $30 \mathrm{ml}$ of hexane to the mixture in the mortar, grind the mixture for $1 \mathrm{~min}$., and decant the supernatant into the Buchner funnel. 
10. Repeat this grinding process with three more portions of hexane, decanting the supernatant into the Buchner funnel each time.

11. Remove the residue remaining in the mortar and transfer it to a $250 \mathrm{ml}$ Erlenmeyer flask; rinse the mortar with three successive $10 \mathrm{ml}$ portions of hexane and add these rinsings to the Erlenmeyer flask; swirl the flask for 1 min.; place it in the shaker water bath for 10 min., and decant the supernatant into the Buchner funnel.

12. Place the residue remaining in the Erlenmeyer flask into the Buchner funnel; rinse the Erlenmeyer flask with three successive $25 \mathrm{ml}$ portions of hexane and pour the rinsings into the Buchner funnel, then press the residue remaining in the Buchner funnel with the bottom of a beaker to force out any remaining hexane.

13. Pour the combined hexane extracts through a $60 \mathrm{~mm} \mathrm{X} 22$ mm i.d. column of anhydrous sodium sulfate and collect the eluate in a Kuderna-Danish evaporator fitted with a 250 $\mathrm{ml}$ flask and a $15 \mathrm{ml}$ collection tube; rinse the flask that contained the extracts with two $10 \mathrm{ml}$ portions of hexane and pour these through the sodium sulfate column.

14. Wash the sodium sulfate column with two $10 \mathrm{ml}$ portions of hexane, collecting the eluate in the evaporator.

15. Evaporate the extracts to a volume of $7-15 \mathrm{ml}$. 
Partitioning Cleanup of Extracts

1. Add hexane to the sample extract to bring the volume up to $15 \mathrm{ml}$, and place it into a $125 \mathrm{ml}$ separatory funnel.

2. Add $30 \mathrm{ml}$ of acetonitrile (reagent grade) saturated with hexane to this funnel, shake the funnel vigorously for 1 min., and let the layers separate.

3. Drain the lower acetonitrile layer into a second $125 \mathrm{ml}$ separatory funnel containing $15 \mathrm{ml}$ of hexane; shake this funnel vigorously for $1 \mathrm{~min}$. and let the layers separate.

4. If emulsions occur in either of these funnels, centrifuge the contents at $3000 \mathrm{rpm}$ for $5 \mathrm{~min}$. to separate the layers.

5. Drain the lower acetonitrile layer from the second $125 \mathrm{ml}$ separatory funnel into a $1 \mathrm{~L}$ funnel containing $650 \mathrm{ml}$ of distilled water, $40 \mathrm{ml}$ of saturated sodium chloride $(\mathrm{NaCl})$, and $100 \mathrm{ml}$ of hexane.

6. Repeat steps 2 and 3, washing the hexane solution in the first $125 \mathrm{ml}$ separatory funnel with three additional $30 \mathrm{ml}$ portions of acetonitrile saturated with hexane, shaking the funnel vigorously, draining the lower acetonitrile layer into the second $125 \mathrm{ml}$ separatory funnel, shaking the funnel, and draining the lower acetonitrile layer into the $1 \mathrm{~L}$ separatory funnel.

7. Hold the $1 \mathrm{~L}$ separatory funnel containing the combined extracts in a horizontal position and mix thoroughly for 30 $45 \mathrm{sec}$; let the layers separate. 
8. Drain the lower aqueous layer into a second $1 \mathrm{~L}$ separatory funnel, add $100 \mathrm{ml}$ of hexane, hold the funnel in a horizontal position, and mix thoroughly for $15 \mathrm{sec}$; let the layers separate and discard the lower aqueous layer.

9. Combine the hexane portions in the two $1 \mathrm{~L}$ separatory funnels into one $1 \mathrm{~L}$ separatory funnel, and wash with two $100 \mathrm{ml}$ portions of distilled water; discard the aqueous layer. (Note: if emulsions occur with the washing of the hexane with water, then there is too much fat in the extract; it would be best to start over at the beginning with a smaller sample of blubber.)

10. Pour the hexane solution through a $60 \mathrm{~mm} \times 22 \mathrm{~mm}$ id. column of anhydrous sodium sulfate, and collect the eluate in a Kuderna-Danish evaporator fitted with a $500 \mathrm{ml}$ flask and a $10 \mathrm{ml}$ collection tube.

11. Rinse both separators with three $10 \mathrm{ml}$ portions of hexane, pour these through the sodium sulfate column, and wash the column with two $10 \mathrm{ml}$ portions of hexane, collecting all the hexane in the Kuderna-Danish evaporator.

12. Evaporate the combined extracts and washings to $4-5 \mathrm{ml}$.

Florisil Cleanup of Extracts Following Partitioning

1 . In a $22 \mathrm{~mm}$ id. glass column add the following in order: small plug of glass wool, $1 \mathrm{~cm}$ of anhydrous sodium sulfate, $10 \mathrm{~cm}$ of activated Florisil, and $1 \mathrm{~cm}$ of anhydrous sodium sulfate. 
2. Prewet the column with $40-50 \mathrm{ml}$ of hexane (HPLC grade).

3. Add the $4-5 \mathrm{ml}$ of the cleaned hexane extract to the top of the column; wash the collection tube that contained the extract with two $2 \mathrm{ml}$ portions of hexane, and add this to the top of the column; drain the cleaned extract and washings into the column until the meniscus reaches the surface of the top sodium sulfate layer.

4. Elute the column with $150 \mathrm{ml}$ of hexane at a flow rate not exceeding $5 \mathrm{ml} / \mathrm{min}$., and collect the eluate in a KudernaDanish evaporator fitted with a $250 \mathrm{ml}$ flask and a $10 \mathrm{ml}$ collection tube; collection of eluate continues until flow has ceased.

5. As the elution proceeds, a bluish band will be observed in the Florisil; this band should remain within the Florisil during the entire elution; if it reaches the bottom of the Florisil before the elution is finished, then the elution must be completed, the eluate evaporated to $4-5 \mathrm{ml}$, and added to the top of a fresh Florisil column, followed by a second elution with hexane.

6. Evaporate the eluate to $4-5 \mathrm{ml}$, remove the collection tube from the flask, fit on a microSnyder column or condenser, and evaporate to $2 \mathrm{ml}$. 
Oxidation of $p, p-D D E$ to $p, p-D C B P$

1. To the $2 \mathrm{ml}$ of Florisil-cleaned extract in the $10 \mathrm{ml}$ collection tube, add $2 \mathrm{ml}$ of glacial acetic acid (reagent grade).

2. Replace the microSnyder column or condenser, and evaporate to $2 \mathrm{ml}$, indicating that all the hexane has been evaporated. 3. Add $100 \mathrm{mg}$ of chromium trioxide $\left(\mathrm{CrO}_{3}\right)$ to the acetic acid in the collection tube, and place in a boiling water bath for 30 min.; the solution will be brownish and will bubble, then will gradually turn green; if it is green immediately, then fat is still present in the cleaned extract, and it will be necessary to start over again from the beginning with a smaller sample of blubber.

4. After $30 \mathrm{~min}$. immersion in the boiling water bath, remove the concentrator tube, and allow it to cool.

5. Transfer the solution to a stoppered test tube, add $2 \mathrm{ml}$ of hexane, shake vigorously for $30 \mathrm{sec}$, and release any gas produced.

6. Add $6-7 \mathrm{ml}$ of $5 \mathrm{~N}$ sodium hydroxide $(\mathrm{NaOH})$ to neutralize the acid, shake vigorously for $30 \mathrm{sec}$., release any gas produced, and allow the layers to separate; the clear top hexane layer contains the organochlorines desired-PCB's and p,p-DCBP, the oxidation product of $\mathrm{p}, \mathrm{p}$-DDE.

7. If the HPLC analysis of the unoxidized Florisil eluate indicates low concentrations of organochlorines, evaporate the hexane layer to $1 \mathrm{ml}$. 
HPLC Analysis of the Cleaned and Oxidized Extracts

1. Fit the HPLC system with a Lichrosorb SI 60, 5 um prepacked adsorption column (E. Merck, Darmstadt, Ger.) preceded by a guard column filled with Perisorb A 30-40 um (Upchurch Scientific, Oak Harbor, Wa.).

2. Fill the mobile phase reservoir with 1 liter of solution: $950 \mathrm{ml}$ of hexane (HPLC grade) and $50 \mathrm{ml}$ of chloroform (HPLC grade).

3. Set the flow rate at $1.4 \mathrm{ml} / \mathrm{min}$, turn on the mixing chamber, and turn on the pump(s).

4. Pump $200 \mathrm{ml}$ of the mobile phase through the column in order to equilibrate it.

5. Turn on the UV detector, set it a $205 \mathrm{~nm}$ and 2.0 AUFS, and turn on the lamp; wait for the absorbance to stabilize.

6. Turn on the integrator-plotter, and set the minimum area at 100.

7. In order to check for the presence of PCB's and/or p,p-DDE, fill a $100 \mathrm{ul}$ syringe with about $50 \mathrm{ul}$ of the Florisil eluate, and inject it into the column with the sample injector valve.

8. If PCB's and/or p,p-DDE are present, perform the oxidation procedure, and fill the $100 \mathrm{ul}$ syringe with about $50 \mathrm{ul}$ of the clear hexane layer; inject this into the column with the sample injector valve.

9. Retain plotted results and integrated areas. 
10. Always rinse the syringe and sample injector valve with hexane after each injection.

11. When finished with a sample, pump at least $30 \mathrm{ml}$ of mobile phase through the column to remove any late-eluting substances.

12 When finished for the day, turn off pump(s), mixing chamber, UV detector and lamp, and integrator-plotter.

13. When finished for a long period of time, fill the mobile phase reservoir with hexane (HPLC grade), and pump at least 200 $\mathrm{ml}$ through the column to equilibrate it; remove the adsorption column and store it in hexane; remove the precolumn, empty out the Perisorb A, rinse the column with hexane, and store it dry; fill the mobile phase reservoir with methanol (HPLC grade), pump it through the HPLC system, and store the system in methanol.

Confirmation of Results with TLC

1. Line the TLC chamber with filter paper, fill it with $50 \mathrm{ml}$ of hexane (HPLC grade), and let it equilibrate for at least 60 $\min$.

2. Prepare the chromogenic reagent as follows: dissolve $1.7 \mathrm{~g}$ of silver nitrate ( $\left.\mathrm{AgNO}_{3}\right)$ in $10 \mathrm{ml}$ of distilled water, add $5 \mathrm{ml}$ of ammonium hydroxide (reagent grade-specific gravity $=0.897$ ), and dilute to $200 \mathrm{ml}$ with acetone (reagent grade); to each $45 \mathrm{ml}$ of this reagent, add $5 \mathrm{ml}$ of 2- 
phenoxyethanol (reagent grade), mix well, place it in a spray bottle, and use it to spray the TLC plates; use within four days.

3. On a precoated aluminum oxide $\left(\mathrm{Al}_{2} \mathrm{O}_{3}-5 \mathrm{~cm} \mathrm{X} 20 \mathrm{~cm}\right) 250$ ug F254 plate scribe a line $2 \mathrm{~cm}$ from the bottom, one 17 $\mathrm{cm}$ from the bottom, one $1.7 \mathrm{~cm}$ from one side, and one 1.7 $\mathrm{cm}$ from the other side; the plate is now divided into three lanes each $1.7 \mathrm{~cm}$ wide and $15 \mathrm{~cm}$ long.

4. Just above the bottom line of one lane, place $5 \mathrm{ul}$ of the cleaned oxidized extract of one sample; in the second lane place $5 \mathrm{ul}$ of standard Aroclor 1254 solution (in hexane); in the third lane place 5 ul of standard p,p-DCBP solution (in hexane).

5. Place the plate in the TLC chamber, and develop it at room temperature until the solvent front reaches the upper scribed line.

6. When development is finished, remove the TLC plate from the chamber, and allow it to dry for $3 \mathrm{~min}$.

7. Place the plate under short-wavelength UV light for $15 \mathrm{~min}$. in a Chromato-vue cabinet, and mark the quenched spots.

8. Remove the plate from the cabinet, spray it with chromogenic reagent until uniformly wet, let the plate dry, and expose it to short-wavelength UV light for another $15 \mathrm{~min}$.

9. Remove the plate from the cabinet, and make a photocopy of the plate. 
10. Compare the migration distances between the sample and the standards to confirm the presence of PCB's and p,p-DDE.

Necessary Calculations

1. To calculate parts per million $(\mathrm{ppm}=\mathrm{ug} / \mathrm{g}=\mathrm{ug} / \mathrm{ml}$ ) of PCB's in a sample:

PCB peak area $X 2 \mathrm{ml} \mathrm{X} 100$

weight of sample $X$ peak area of standard Aroclor 1254

(100 ug/ml)

2. To calculate $\mathrm{ppm}$ of $\mathrm{p}, \mathrm{p}$-DDE in a sample:

p,p-DCBP peak area $X 2 \mathrm{ml} \times 100$

weight of sample $X$ peak area of standard p,p-DCBP $(100 \mathrm{ug} / \mathrm{ml})$

3. To determine recovery of PCB's or $p, p-D D E:$

peak area of spiked sample $X 2 \mathrm{ml}$

peak area of unspiked sample + peak area of standard (use the same weight of sample both times)

4. To calculate TLC mobilities ( $\mathrm{f} f$ values):

distance from point of application to center of the spot distance the solvent front traveled $(15 \mathrm{~cm})$ 
APPENDIX C

HPLC AND TLC CHROMATOGRAMS

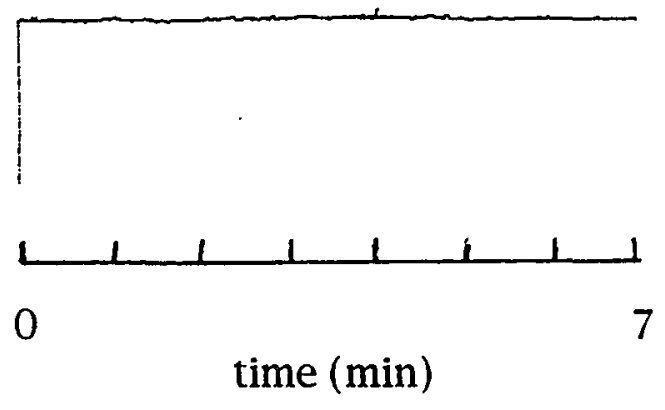

Figure 17. Hexane only.

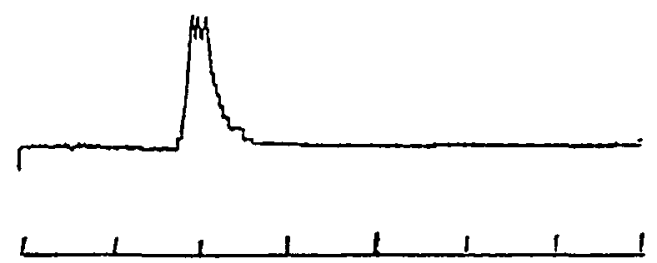

0

time (min)

Figure 18. Aroclor 1254 standard @ 100 ug/ml. 


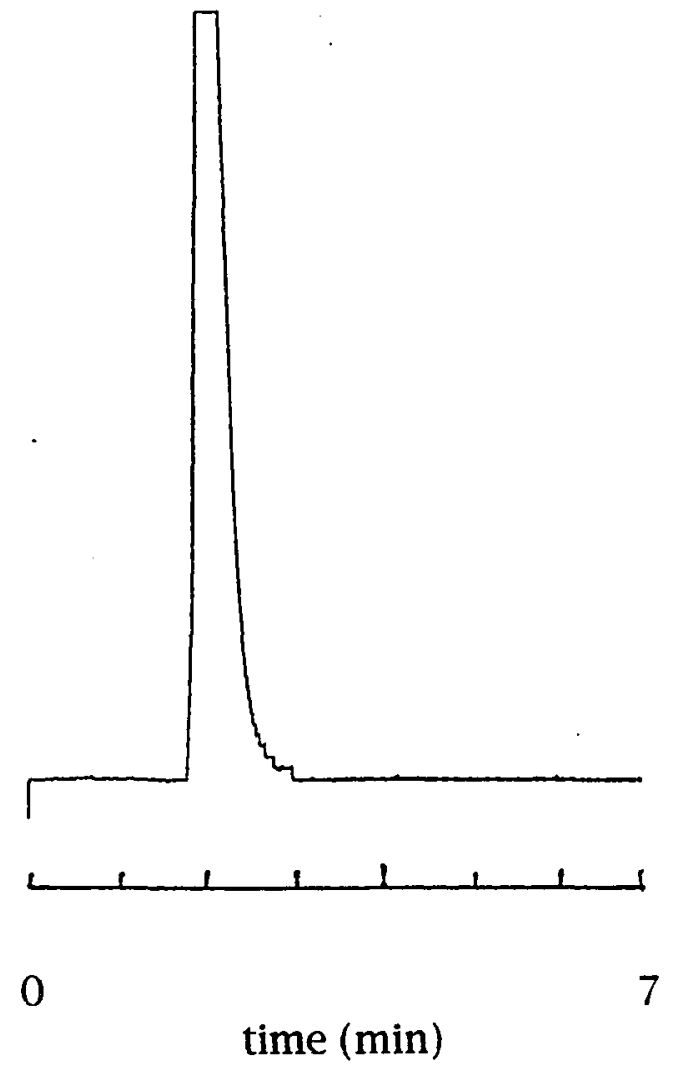

Figure 19. Aroclor 1254 standard @ $1000 \mathrm{ug} / \mathrm{ml}$. 

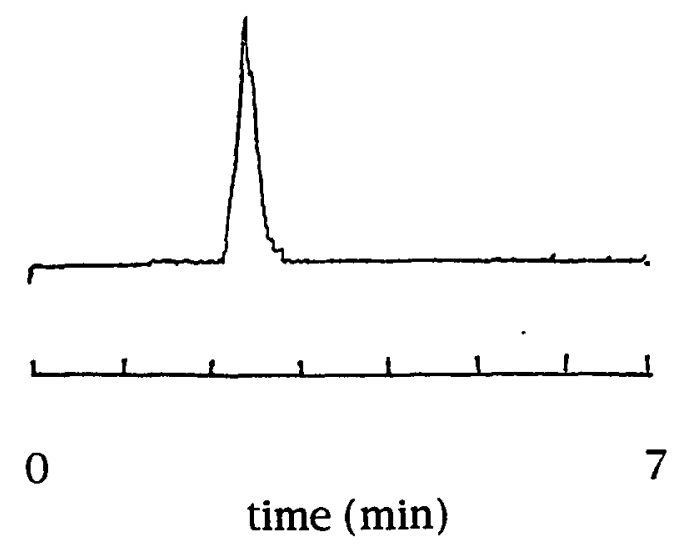

(a)

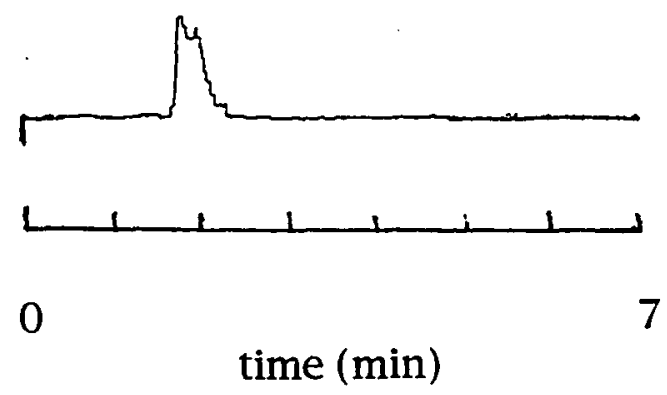

(b)

Figure 20. Aroclor standards @ $100 \mathrm{ug} / \mathrm{ml}$ :

(a) Aroclor 1248, (b) Aroclor 1260. 

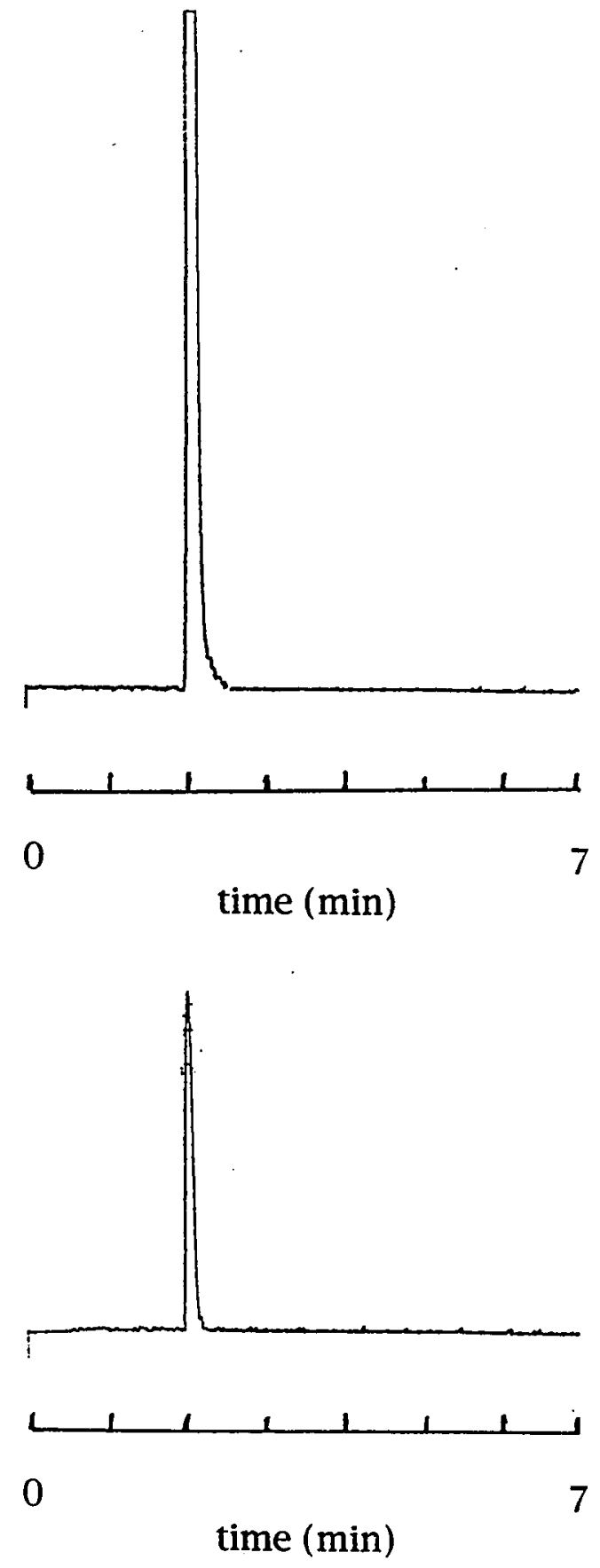

(b)

Figure 21. p,p-DDE standards: (a) $100 \mathrm{ug} / \mathrm{ml}$, (b) $10 \mathrm{ug} / \mathrm{ml}$. 


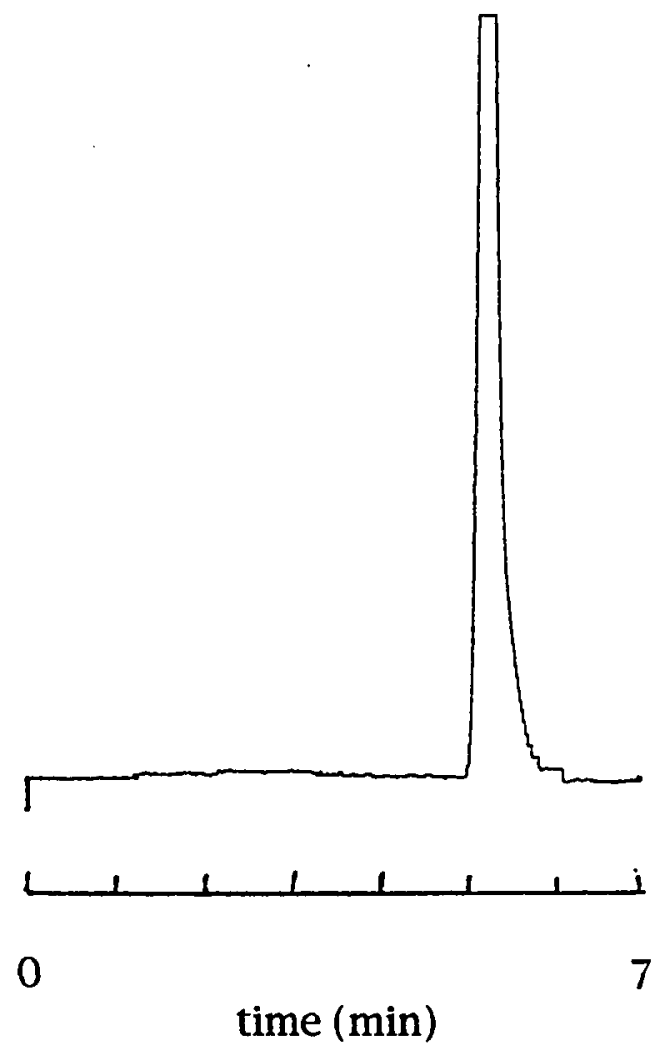

Figure 22. p,p DCBP standard @ 100 ug $/ \mathrm{ml}$. 


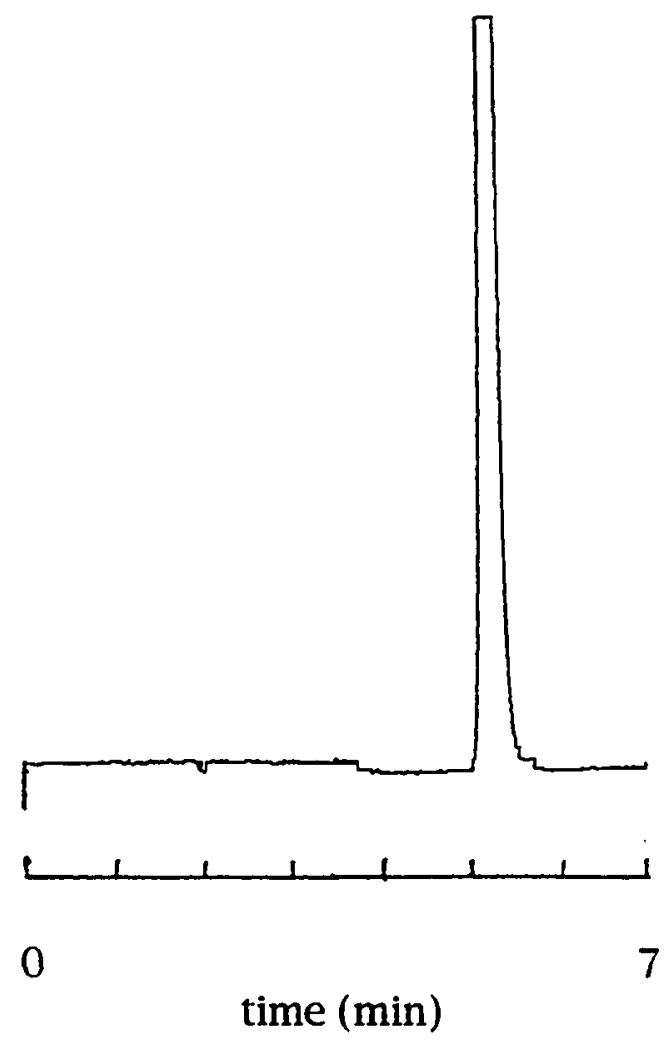

Figure 23. Oxidized p,p-DDE standard @ $100 \mathrm{ug} / \mathrm{ml}$. 


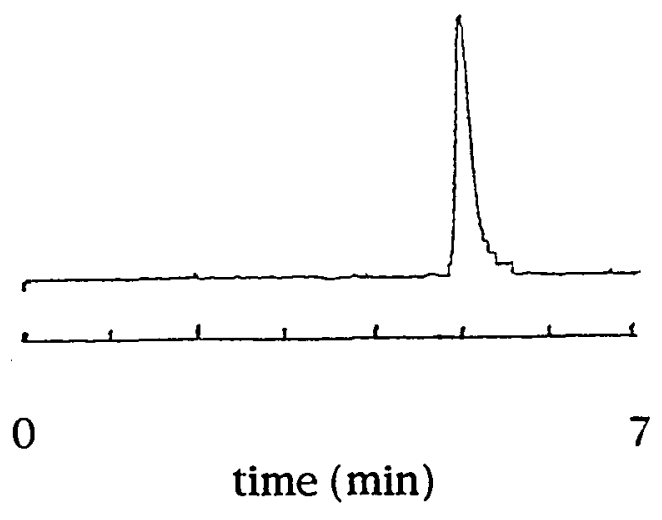

(a)

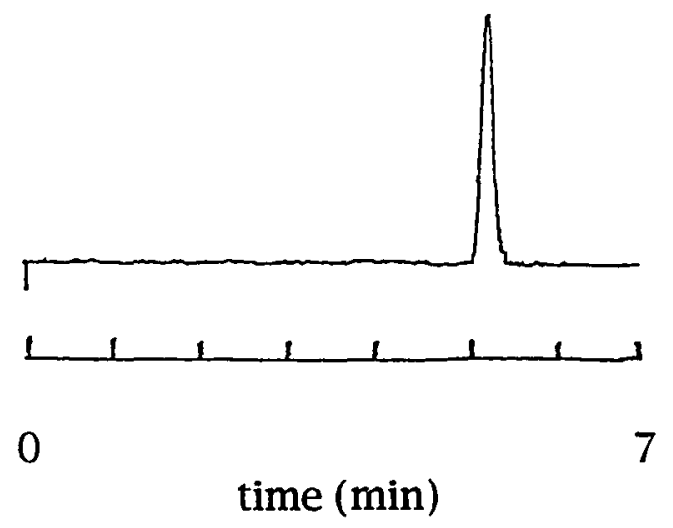

(b)

Figure 24. Oxidized standards: (a) p,p-DCBP @ $10 \mathrm{ug} / \mathrm{ml}$, (b) p,p-DDE @ $10 \mathrm{ug} / \mathrm{ml}$. 


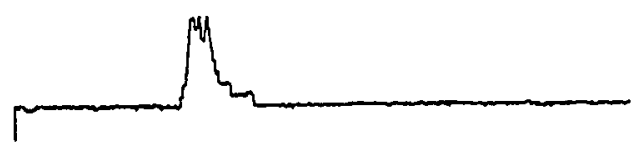

0

time (min)

Figure 25. Oxidized Aroclor 1254 standard @ $100 \mathrm{ug} / \mathrm{ml}$.

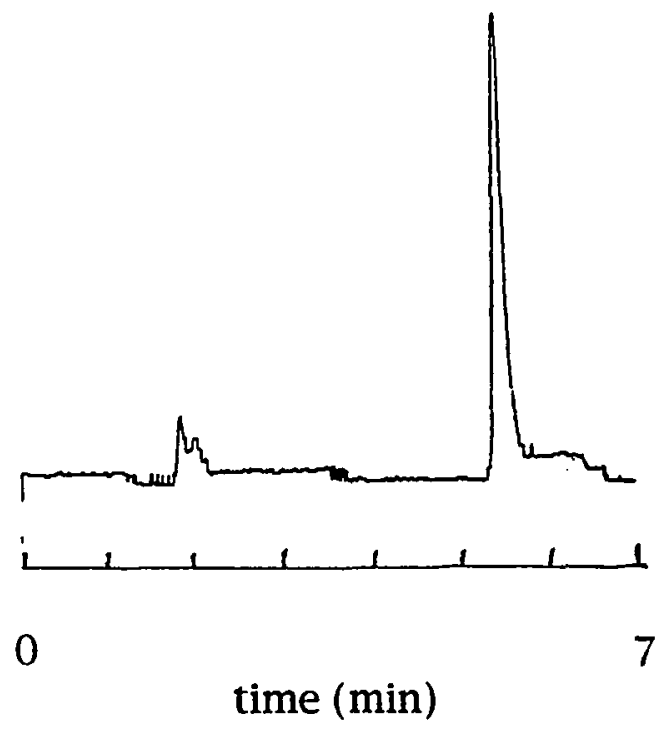

Figure 26. Oxidized solution of Aroclor 1260 standard

@ $100 \mathrm{ug} / \mathrm{ml}$ and p,p-DDE@ $45 \mathrm{ug} / \mathrm{ml}$,

Mean peak area of Aroclor 1260 standard $=1435$,

Peak area of above oxidized 1260 standard $(2 \mathrm{ml})=618$,

$$
\text { Recovery }=\frac{618 \times 2}{1435}=86.1 \%
$$

1435

Mean peak area of oxidized p,p-DDE standard @ $45 \mathrm{ug} / \mathrm{ml}=8640$,

Peak area of above oxidized p,p-DDE standard $(2 \mathrm{ml})=3639$,

$$
\text { Recovery }=\frac{3639 \times 2}{8640}=84.2 \%
$$




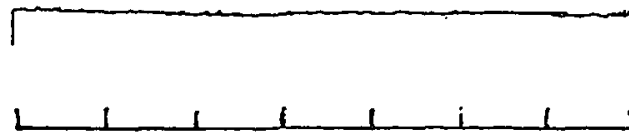

0

time (min)

Figure 27. Cleaned and oxidized extract from organically raised cattle.

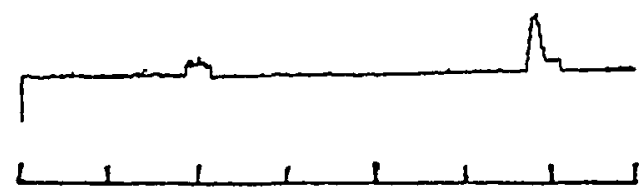

0

time (min)

Figure 28. NIST/NOAA whale blubber sample SRM 1945:

$$
\mathrm{PCB}=1312 \mathrm{ppb}=1312 \mathrm{ug} / \mathrm{kg} \text { wet wt., }
$$

$\mathrm{p}, \mathrm{p}-\mathrm{DDE}=445 \mathrm{ppb}=445 \mathrm{ug} / \mathrm{kg}$ wet $\mathrm{wt}$.

Original sample $=7 \mathrm{~g}$, oxidized sample volume $=1 \mathrm{ml}$,

Peak area of above oxidized sample (PCB's) $=181.5$,

$$
\text { Recovery }=\frac{181.5 \times 100}{7 \times 2395 \times 1.312}=82.5 \%
$$

(mean peak area of Aroclor 1254 standard @ $100 \mathrm{ug} / \mathrm{ml}=2395$ )

Peak area of above oxidized sample $(p, p-D D E)=488$,

$$
\text { Recovery }=488 \times 100=81.6 \%
$$

$7 \times 19200 \times 0.445$

(mean peak area of p,p-DCBP standard @ $100 \mathrm{ug} / \mathrm{ml}=19200$ ). 


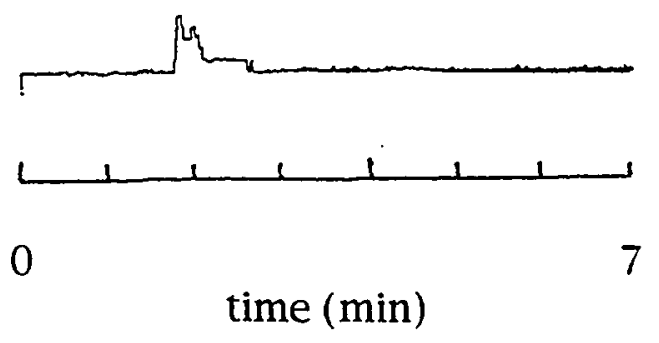

Figure 29. Cleaned and oxidized extract of sample from organically raised cattle spiked with $1 \mathrm{ml}$ of Aroclor 1260 standard @ $100 \mathrm{ug} / \mathrm{ml}$,

Peak area of above oxidized 1260 standard $(2 \mathrm{ml})=598$, Recovery $=\frac{598 \times 2}{1435}=83.3 \%$

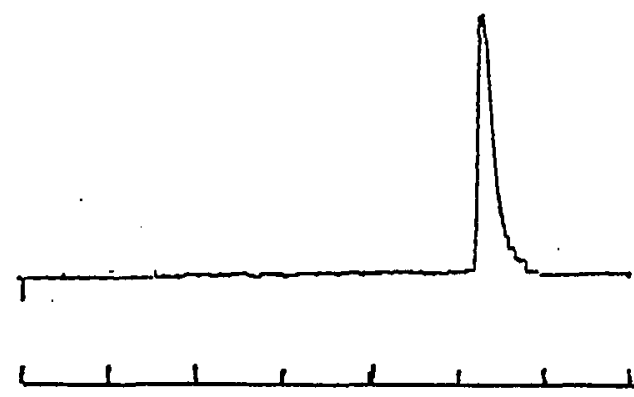

0

time (min)

Figure 30. Cleaned and oxidized extract of sample from organically raised cattle spiked with $1 \mathrm{ml}$ of p,p-DDE standard @ $45 \mathrm{ug} / \mathrm{ml}$, Peak area of above oxidized p,p-DDE $(2 \mathrm{ml})=3195$, Recovery $=\frac{3195 \times 2}{8460}=74.0 \%$ 


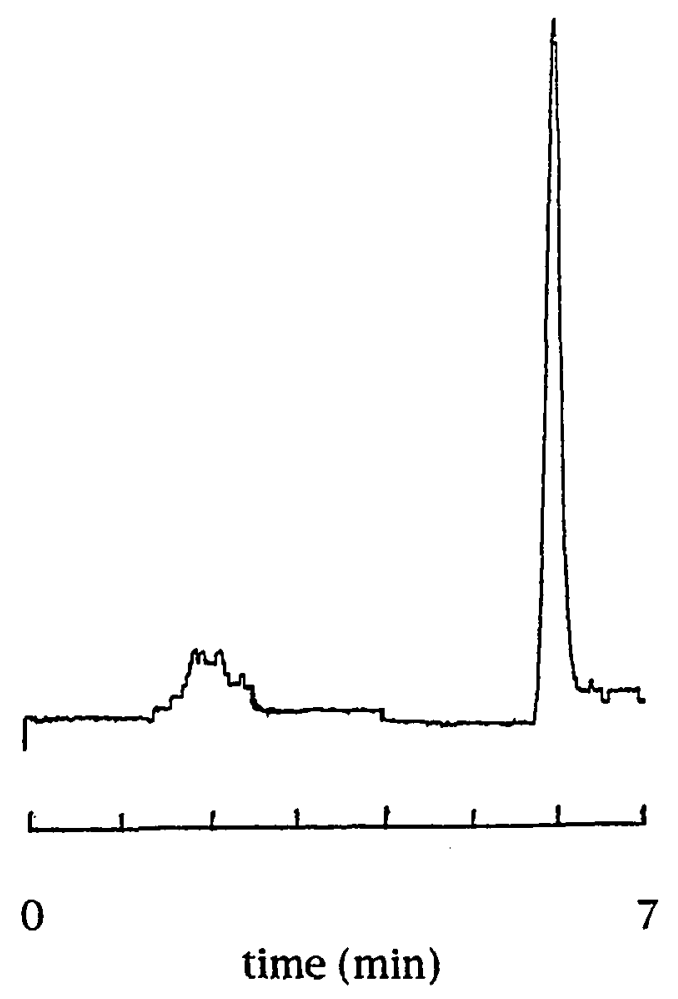

Figure 31. Cleaned and oxidized extract of sample of the beaked whale spiked with $1 \mathrm{ml}$ of Aroclor $1254 @ 100 \mathrm{ug} / \mathrm{ml}$, and $1 \mathrm{ml}$ of $\mathrm{p}, \mathrm{p}-\mathrm{DDE} @ 45 \mathrm{ug} / \mathrm{ml}$,

Mean peak areas of spikes: $1254=2395, \mathrm{p}, \mathrm{p}-\mathrm{DDE}=8329$, Mean peak areas of unspiked extract: $\mathrm{PCB}=0, \mathrm{p}, \mathrm{p}-\mathrm{DDE}=6646$, Mean peak areas in above oxidized extract $(1.8 \mathrm{ml})$ :

$$
\mathrm{PCB}=1263, p, p-D D E=7224 \text {, }
$$$$
\text { Recovery }(\text { PCB's })=\underline{1265 \times 1.8}=94.9 \%
$$$$
2395
$$

Recovery $(\mathrm{p}, \mathrm{p}-\mathrm{DDE})=7224 \times 1.8=86.8 \%$

$$
8329+6646
$$




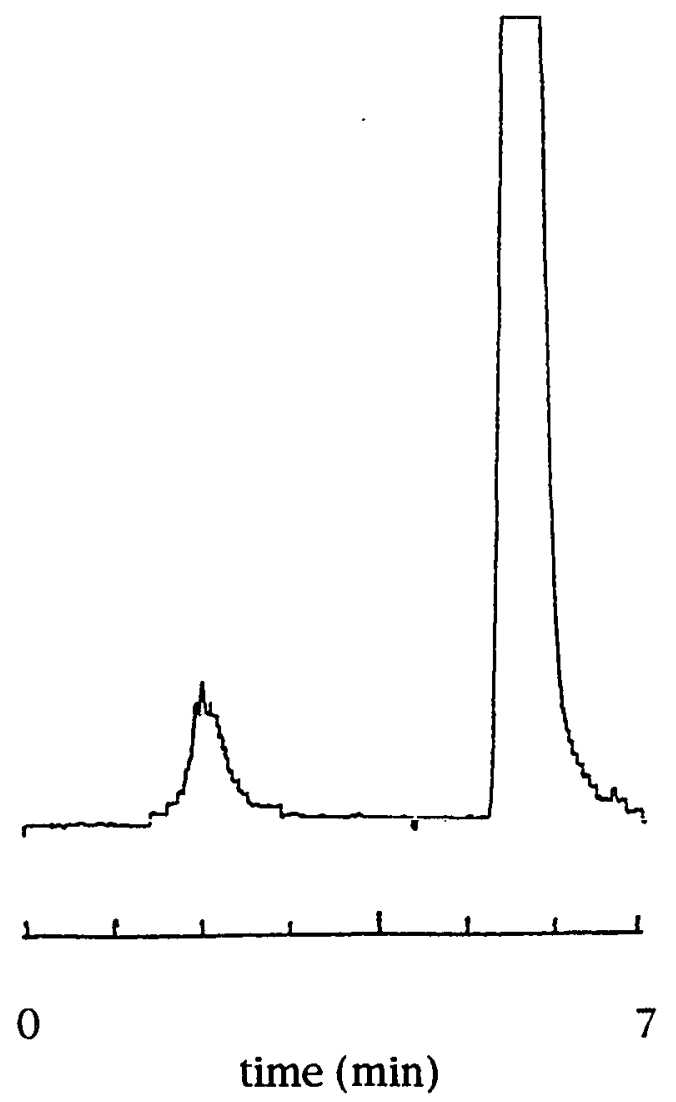

Figure 32. Cleaned and oxidized extract of sample of the striped dolphin spiked with $1 \mathrm{ml}$ of Aroclor 1254 @ $100 \mathrm{ug} / \mathrm{ml}$ and $1 \mathrm{ml}$ of $\mathrm{p}, \mathrm{p}-\mathrm{DDE} @ 45 \mathrm{ug} / \mathrm{ml}$, Mean peak areas of spikes: $1254=2395, \mathrm{p}, \mathrm{p}-\mathrm{DDE}=8830$, Mean peak areas of unspiked extract: $\mathrm{PCB}=922$, $\mathrm{p}, \mathrm{p}-\mathrm{DDE}=46918$,

Mean peak areas in above oxidized extract $(1 \mathrm{ml})$ : PCB's $=2714, p, p-D D E=55435$, Recovery $($ PCB's $)=\underline{2714}=81.8 \%$ $2395+922$

Recovery $(p, p-D D E)=\underline{55435}=99.4 \%$

$46918+8830$ 


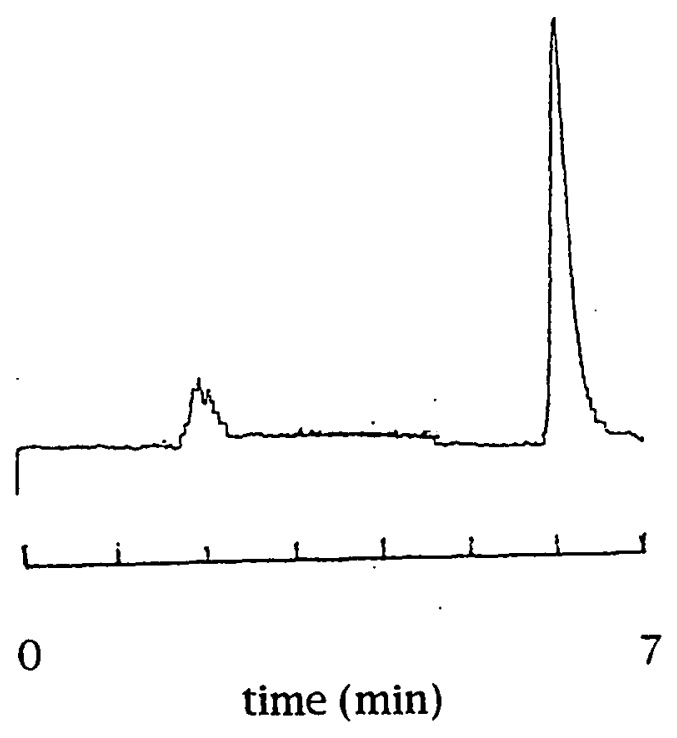

Figure 33. Cleaned and oxidized extract of sample of the harbor porpoise $(1 / 13 / 96)$ spiked with $1 \mathrm{ml}$ of

Aroclor $1254 @ 100 \mathrm{ug} / \mathrm{ml}$, and $1 \mathrm{ml}$ of p,p-DDE @ $50 \mathrm{ug} / \mathrm{ml}$, Mean peak areas of spikes: $1254=2395, \mathrm{p}, \mathrm{p}-\mathrm{DDE}=9978$, Mean peak areas in unspiked extract: PCB's $=116$,

$$
\mathrm{p}, \mathrm{p}-\mathrm{DDE}=3574
$$

Mean peak areas in above oxidized extract $(2 \mathrm{ml})$ :

PCB's $=1584, p, p-D D E=10668$,

Recovery $(\mathrm{PCB} ' \mathrm{~s})=1584 \times 2=63.1 \%$

$2395+116$

Recovery $(\mathrm{p}, \mathrm{p}-\mathrm{DDE})=10668 \times 2=78.7 \%$

$9978+3574$ 


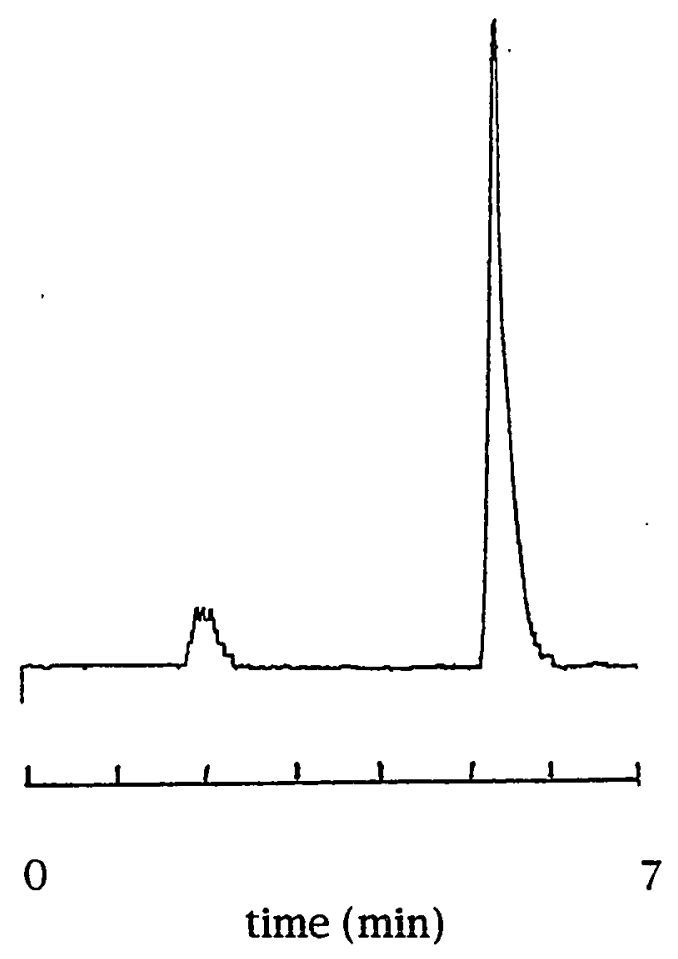

Figure 34. Cleaned and oxidized extract of sample of the harbor seal $(10 / 10 / 95)$ spiked with $1 \mathrm{ml}$ of

Aroclor $1254 @ 100 \mathrm{ug} / \mathrm{ml}$ and $1 \mathrm{ml}$ of p,p-DDE @ $45 \mathrm{ug} / \mathrm{ml}$,

Mean peak areas of spikes: $1254=2395, \mathrm{p}, \mathrm{p}-\mathrm{DDE}=\mathbf{8 9 0 0}$,

Mean peak areas in unspiked extracts: PCB's $^{\prime}=0, p, p-D D E=7936$, Mean peak areas in above oxidized extract $(2 \mathrm{ml})$ :

$$
\begin{gathered}
\text { PCB's }=935, p, p-D D E=7996, \\
\text { Recovery (PCB's) }=\underline{935 \times 2}=78.1 \%
\end{gathered}
$$$$
2395
$$

Recovery (p,p-DDE) $=\underline{7996 \times 2}=95.0 \%$

$8900+7936$ 


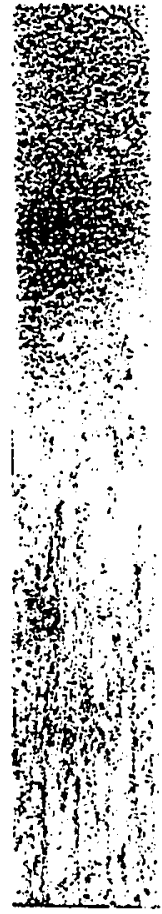

(a)
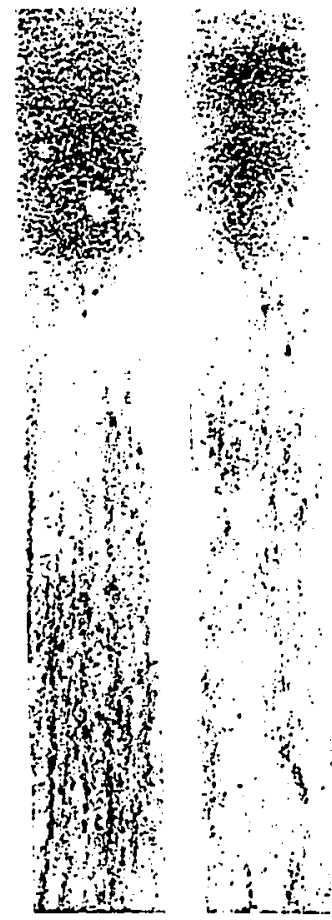

(b)

(c)

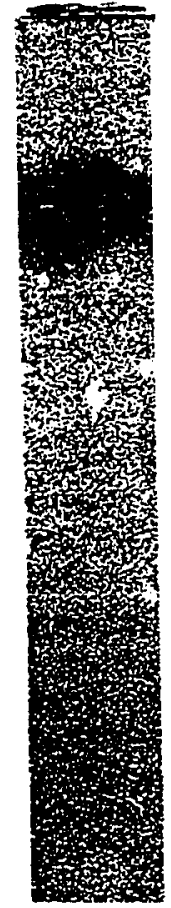

(d)

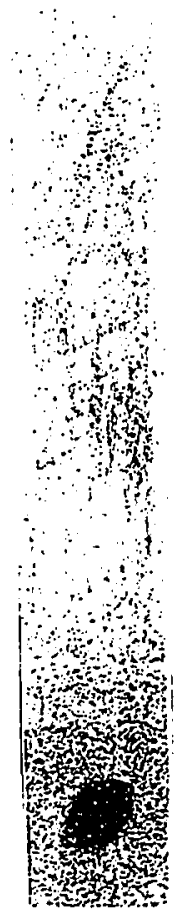

(e)

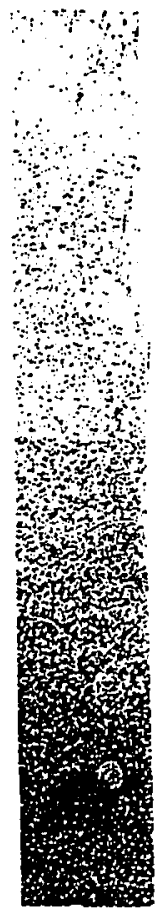

(f)

Figure 35. TLC confirmatory chromatograms of standards @ $100 \mathrm{ug} / \mathrm{ml}$ : (a) Aroclor 1248, (b) Aroclor 1254, (c) Aroclor 1260, (d) p,p-DDE, (e) p,p-DCBP, (f) oxidized p,p-DDE. 


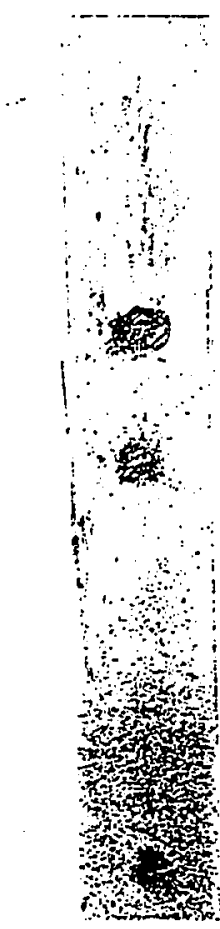

(a)

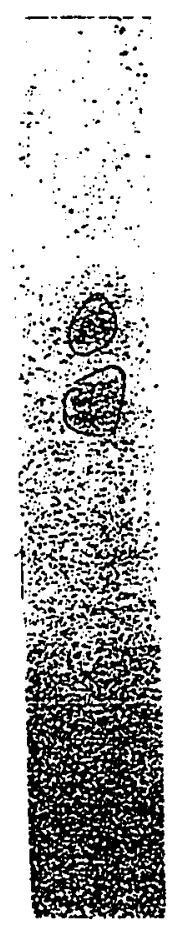

(b)

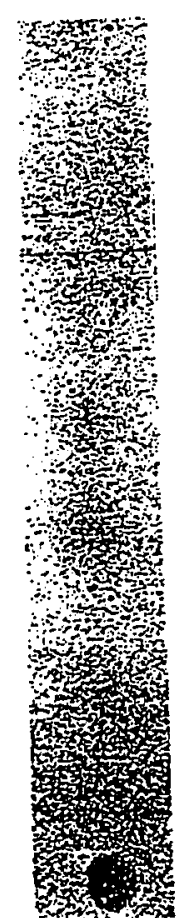

(c)

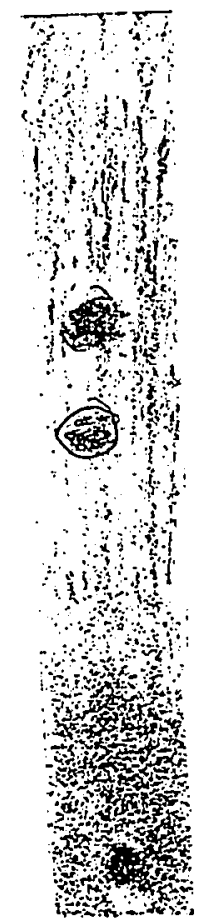

(d)

Figure 36. TLC confirmatory chromatograms of cleaned and oxidized extracts of samples of the

(a) Steller's sea lion $(4 / 4 / 91)$, (b) harbor porpoise $(4 / 15 / 95)$,

(c) common dolphin (5/6/93),

(d) striped dolphin (4/15/95). 


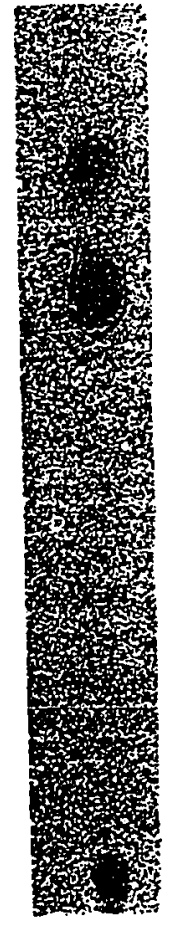

(a)

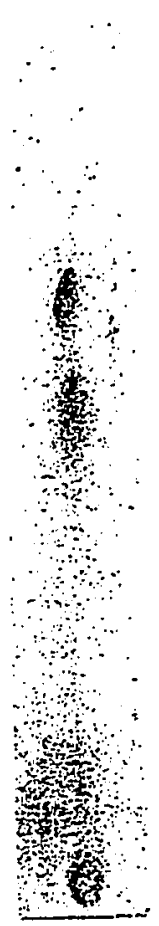

(b)

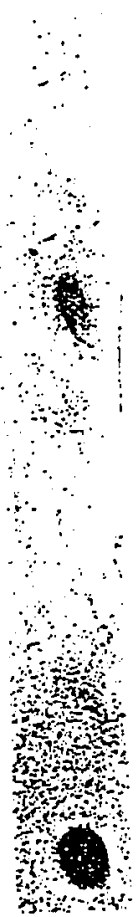

(c)

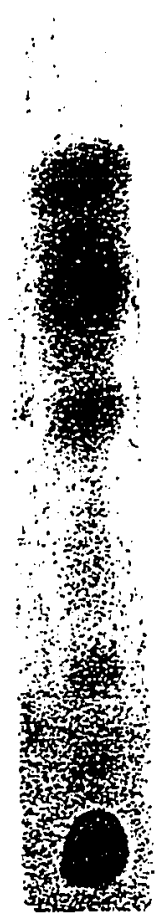

(d)

Figure 37. TLC confirmatory chromatograms of cleaned and oxidized extracts of samples of the

(a) false killer whale $(10 / 8 / 93)$,

(b) Commerson's dolphin (1983),

(c) killer whale $(7 / 24 / 93)$,

(d) killer whale $(5 / 13 / 95)$. 


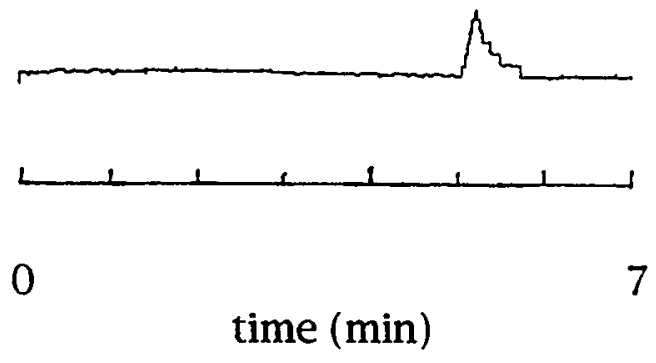

Figure 38. Harbor seal (Phoca vitulina) - (5/10/91).

$$
\begin{gathered}
0.9 \mathrm{ml} \\
\mathrm{p}, \mathrm{p}-\mathrm{DDE}=0.4 \mathrm{ppm}, \quad \mathrm{PCB}^{\prime} \mathrm{s}=\mathrm{ND}
\end{gathered}
$$

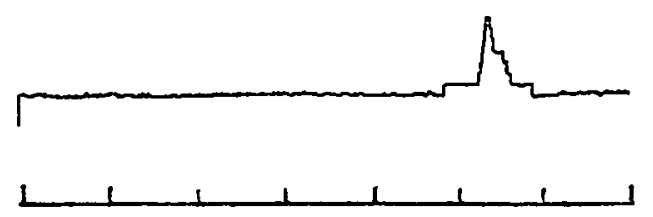

0

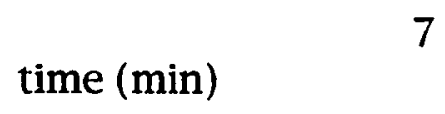

Figure 39. Harbor seal (Phoca vitulina) - (2/24/92).

$$
2 \mathrm{ml}
$$$$
\mathrm{p}, \mathrm{p}-\mathrm{DDE}=1.0 \mathrm{ppm}, \quad \mathrm{PCB} \mathrm{s}^{\prime}=\mathrm{ND}
$$ 


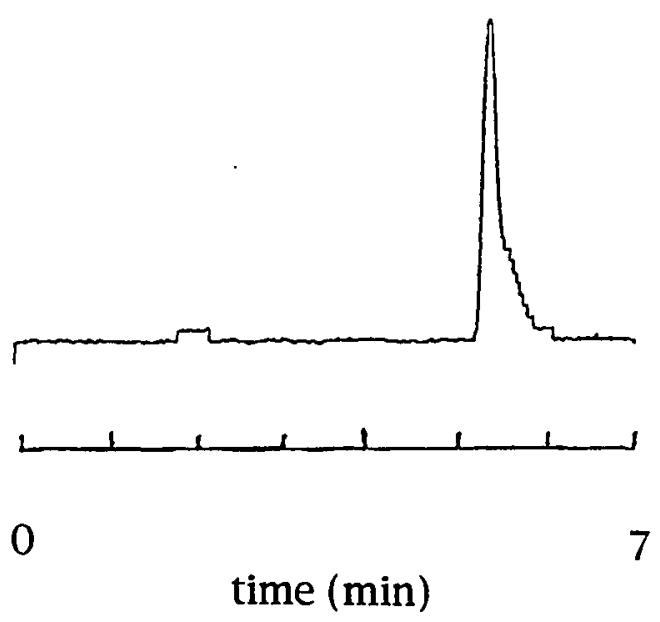

Figure 40. Harbor seal (Phoca vitulina) - (10/10/95).

$2 \mathrm{ml}$

$\mathrm{p}, \mathrm{p}-\mathrm{DDE}=5.8 \mathrm{ppm}, \quad \mathrm{PCB} \mathrm{s}^{\prime}=1.7 \mathrm{ppm}$

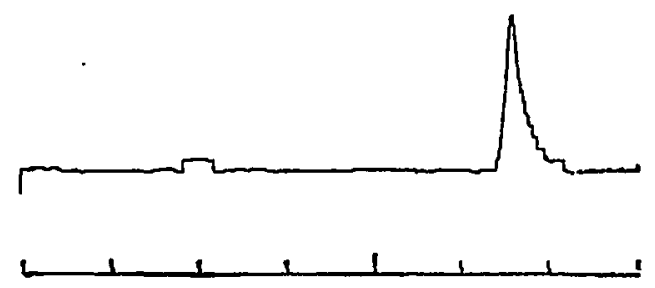

0

time ( $\min$ )

Figure 41. Harbor seal (Phoca vitulina) - (3/1/91).

$1 \mathrm{ml}$

$\mathrm{p}, \mathrm{p}-\mathrm{DDE}=2.3 \mathrm{ppm}, \quad \mathrm{PCB}^{\prime} \mathrm{s}=<1.0 \mathrm{ppm}$ 

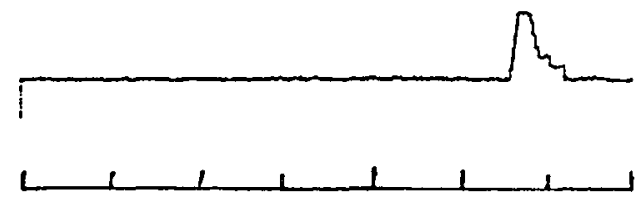

0

time (min)

Figure 42. Harbor seal (Phoca vitulina) - (2/23/92).

$1 \mathrm{ml}$

$\mathrm{p}, \mathrm{p}-\mathrm{DDE}=0.8 \mathrm{ppm}, \quad \mathrm{PCB}^{\prime} \mathrm{s}=\mathrm{ND}$

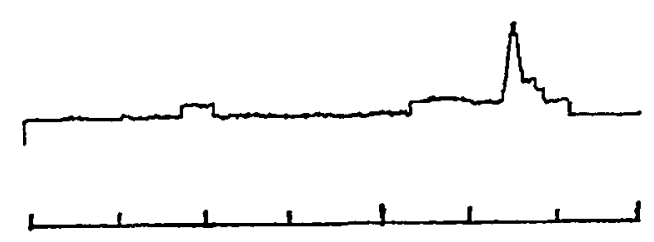

0

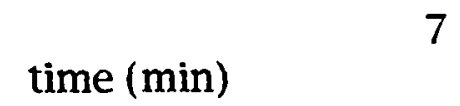

Figure 43. Harbor seal (Phoca vitulina) - (2/24/92).

$2 \mathrm{ml}$

$\mathrm{p}, \mathrm{p}-\mathrm{DDE}=0.7 \mathrm{ppm}, \quad \mathrm{PCB} ' \mathrm{~s}=<1.1 \mathrm{ppm}$ 

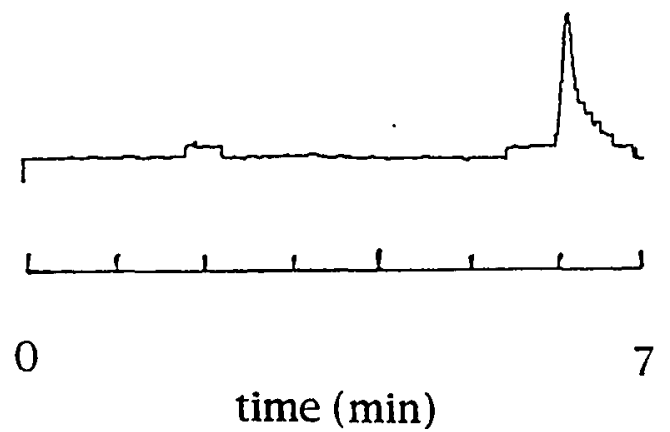

Figure 44. Harbor seal (Phoca vitulina) - (4/10/95).

$2 \mathrm{ml}$

$\mathrm{p}, \mathrm{p}-\mathrm{DDE}=2.2 \mathrm{ppm}, \quad \mathrm{PCB} \mathrm{B}^{\prime} \mathrm{s}=<1.4 \mathrm{ppm}$

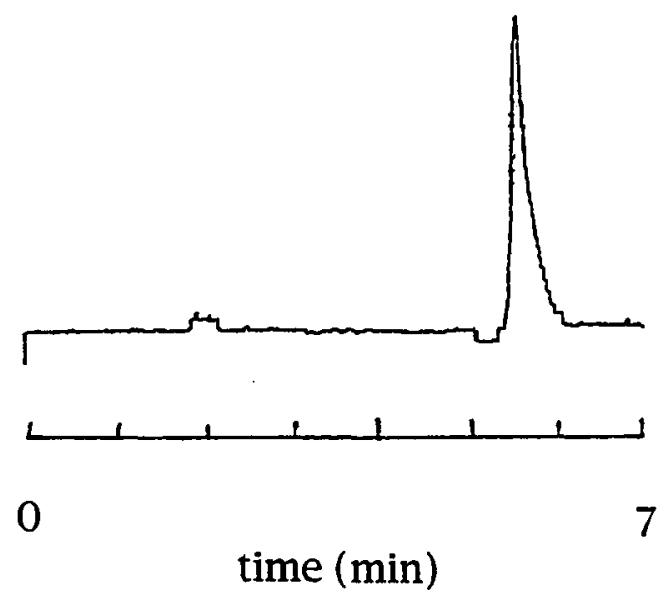

Figure 45. Harbor seal (Phoca vitulina) - (8/11/95).

$$
2 \mathrm{ml}
$$

$\mathrm{p}, \mathrm{p}-\mathrm{DDE}=6.2 \mathrm{ppm}, \quad \mathrm{PCB} \mathrm{s}^{\prime}=<1.3 \mathrm{ppm}$ 


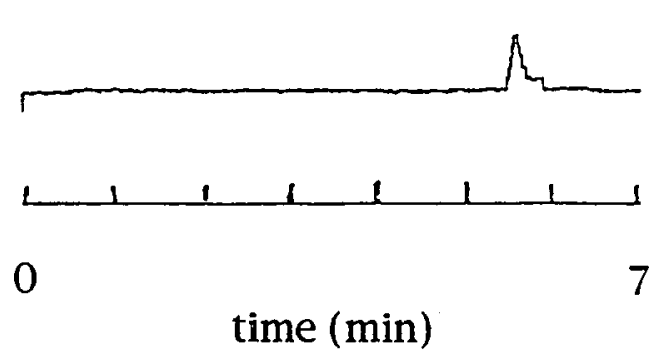

Figure 46. Harbor seal (Phoca vitulina) - (4/18/95).

$2 \mathrm{ml}$

$\mathrm{p}, \mathrm{p}-\mathrm{DDE}=1.0 \mathrm{ppm}, \quad \mathrm{PCB}^{\prime} \mathrm{s}=\mathrm{ND}$

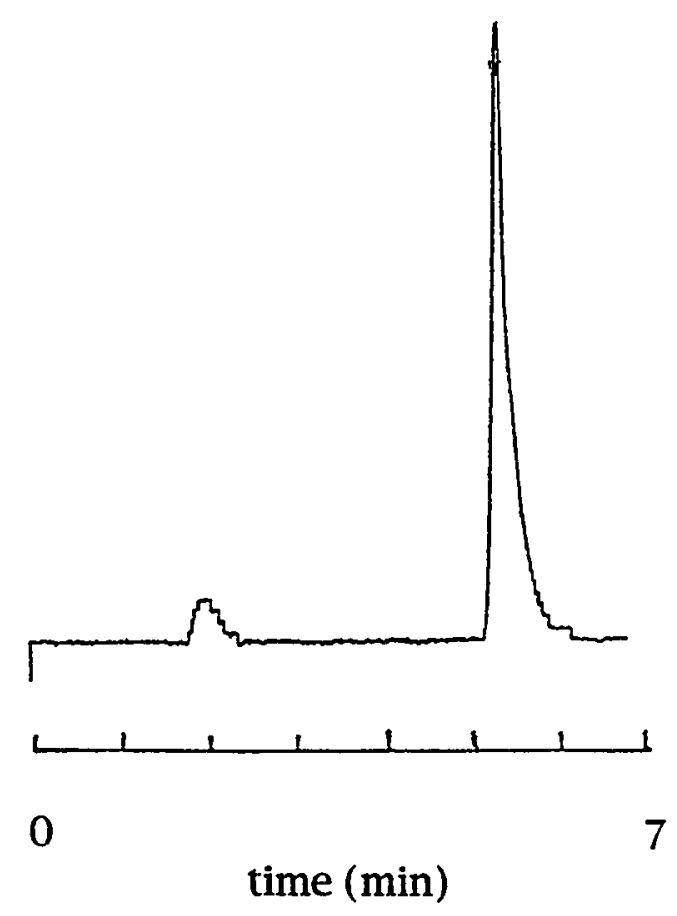

Figure 47. Harbor seal (Phoca vitulina) - (7/15/95).

$2 \mathrm{ml}$

$\mathrm{p}, \mathrm{p}-\mathrm{DDE}=12.5 \mathrm{ppm}, \quad \mathrm{PCB}^{\prime} \mathrm{s}=6.1 \mathrm{ppm}$ 


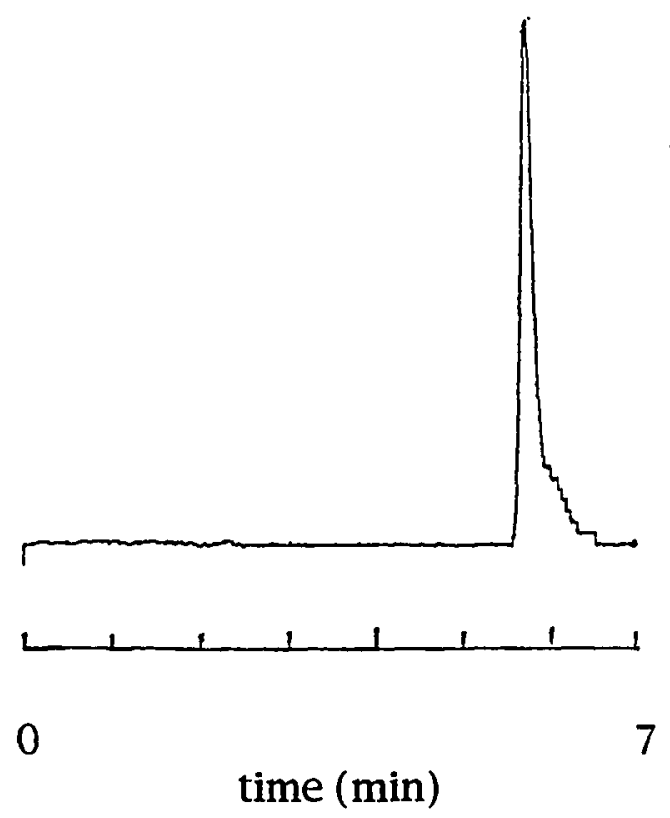

Figure 48. California sea lion (Zalophus californianus) (1988).

$2 \mathrm{ml}$

$\mathrm{p}, \mathrm{p}-\mathrm{DDE}=12.8 \mathrm{ppm}, \quad \mathrm{PCB} ' \mathrm{~s}=\mathrm{ND}$ 


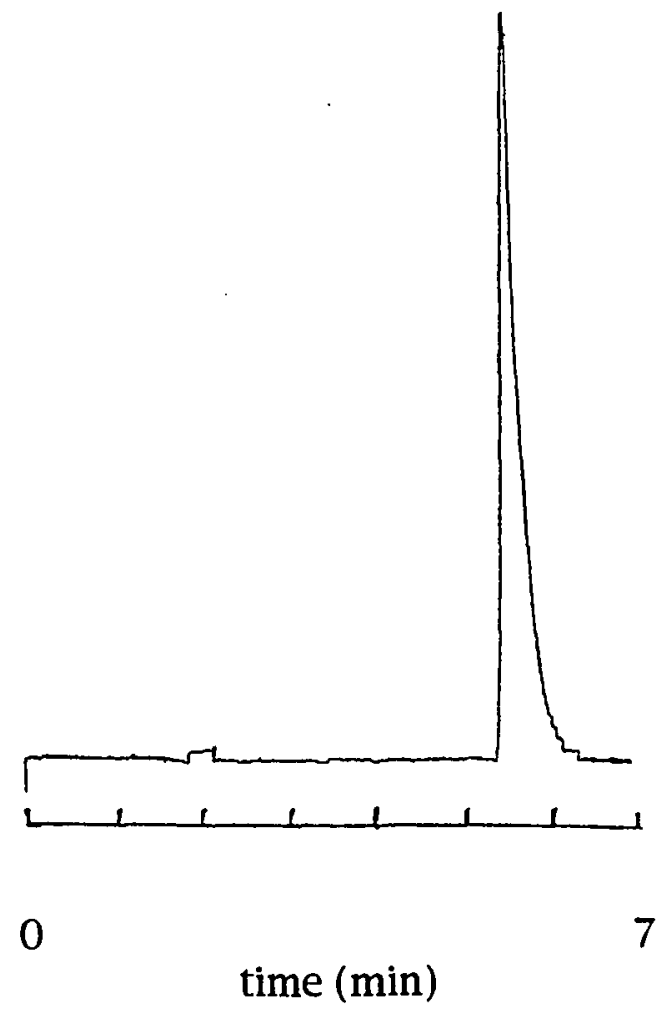

Figure 49. California sea lion (Zalophus californianus) $(2 / 26 / 91)$.

$2 \mathrm{ml}$

$\mathrm{p}, \mathrm{p}-\mathrm{DDE}=15.4 \mathrm{ppm}, \quad \mathrm{PCB}^{\prime} \mathrm{s}=<1.3 \mathrm{ppm}$ 


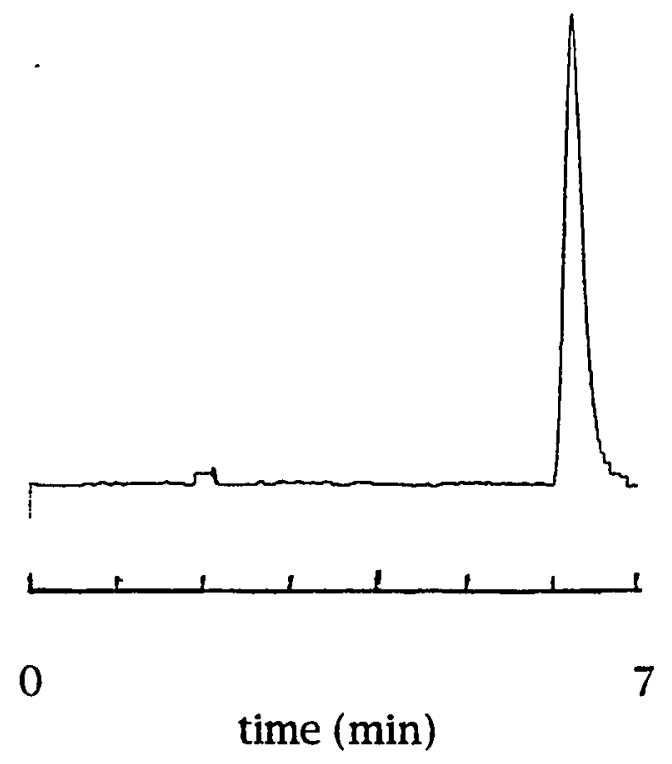

Figure 50. California sea lion (Zalophus californianus) $(2 / 25 / 92)$.

$$
2 \mathrm{ml}
$$

$$
\mathrm{p}, \mathrm{p}-\mathrm{DDE}=10.6 \mathrm{ppm}, \quad \mathrm{PCB} \mathrm{s}=2.0 \mathrm{ppm}
$$




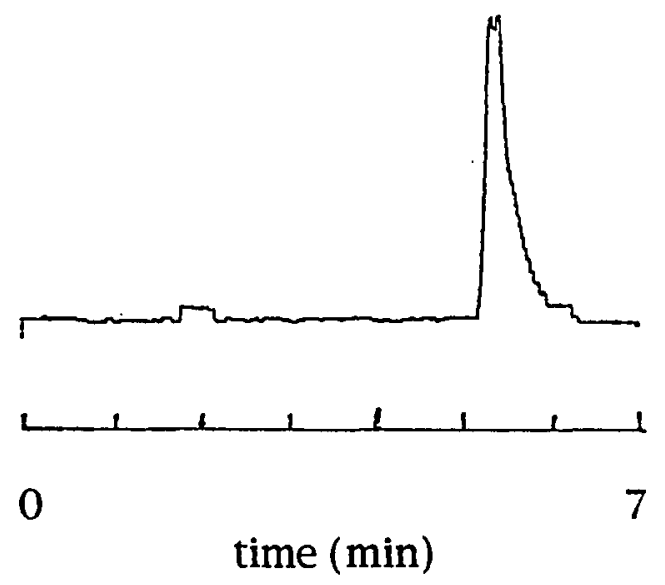

Figure 51. California sea lion (Zalophus californianus) $(2 / 28 / 92)$.

$2 \mathrm{ml}$

$\mathrm{p}, \mathrm{p}-\mathrm{DDE}=7.2 \mathrm{ppm}, \quad \mathrm{PCB} ' \mathrm{~s}=<1.1 \mathrm{ppm}$ 


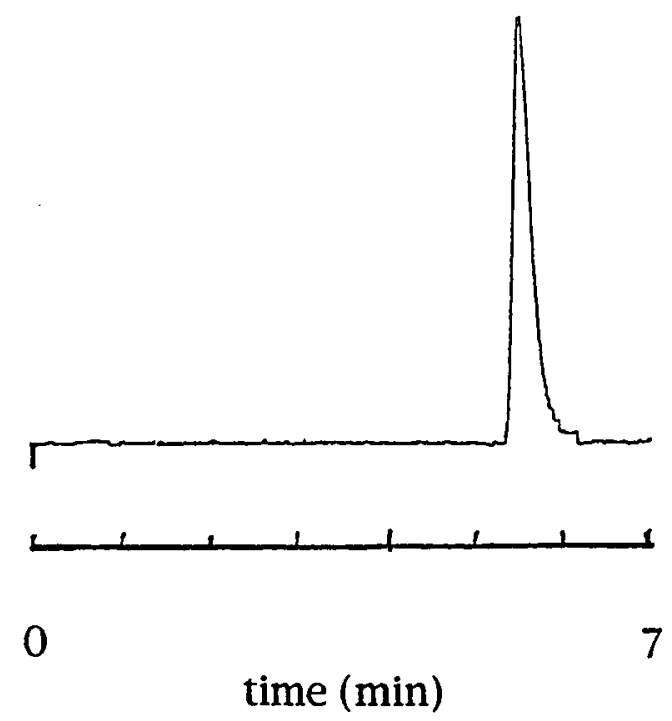

Figure 52. California sea lion (Zalophus californianus) $(12 / 6 / 95)$.

$2 \mathrm{ml}$

$\mathrm{p}, \mathrm{p}-\mathrm{DDE}=9.3 \mathrm{ppm}, \quad \mathrm{PCB} \cdot \mathrm{s}=\mathrm{ND}$ 


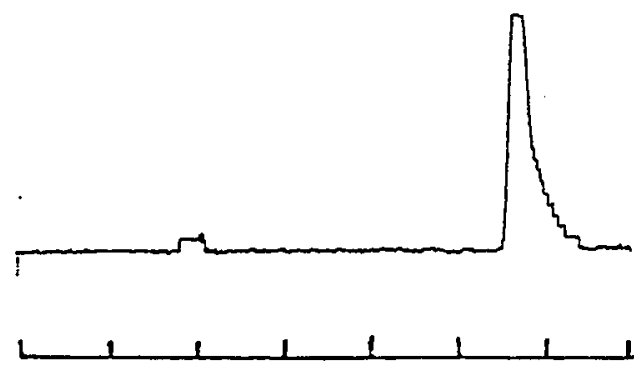

0 time (min)

Figure 53. California sea lion (Zalophus californianus) $(2 / 25 / 92$, juvenile).

$1 \mathrm{ml}$

$\mathrm{p}, \mathrm{p}-\mathrm{DDE}=3.2 \mathrm{ppm}, \quad \mathrm{PCB}^{\prime} \mathrm{s}=1.0 \mathrm{ppm}$ 


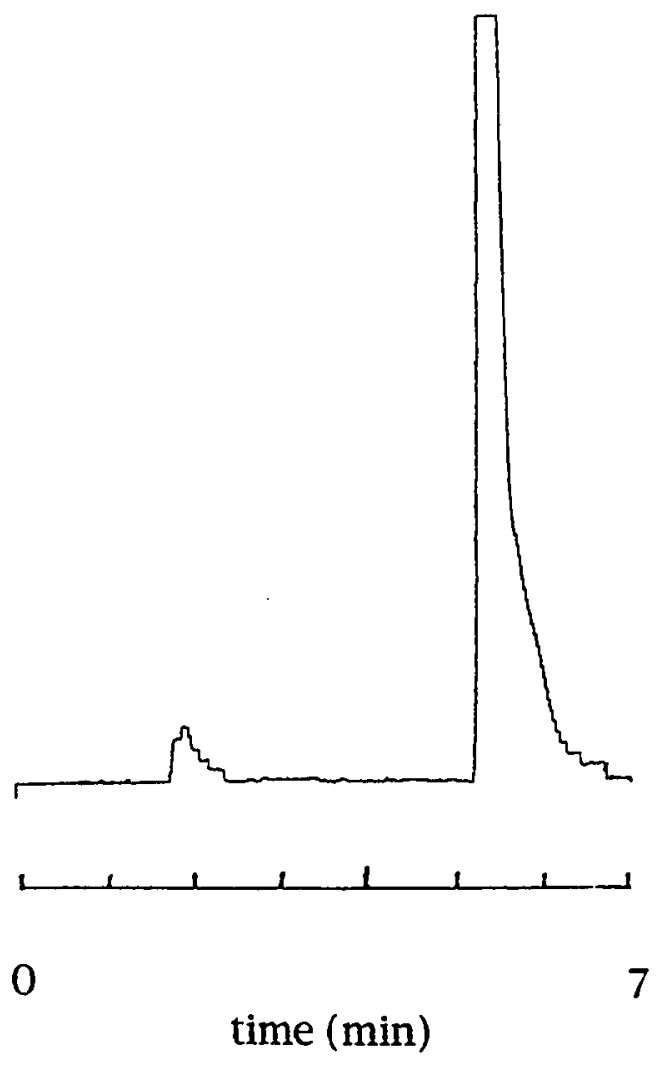

Figure 54. Steller's sea lion (Eumetopias jubatus) (4/4/91).

$$
2 \mathrm{ml}
$$

$\mathrm{p}, \mathrm{p}-\mathrm{DDE}=31.3 \mathrm{ppm}, \quad \mathrm{PCB}^{\prime} \mathrm{s}=8.7 \mathrm{ppm}$ 


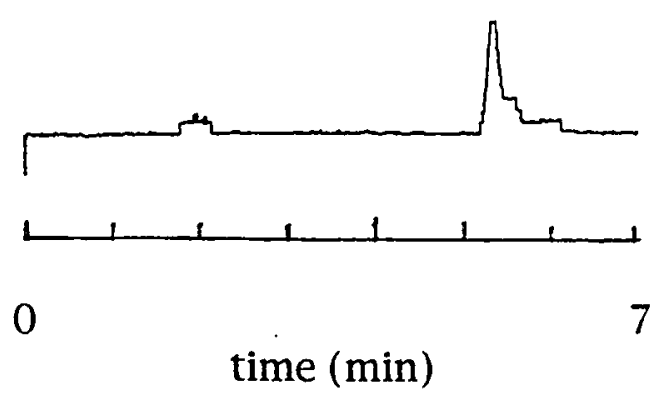

Figure 55. Steller's sea lion (Eumetopias jubatus) $(4 / 15 / 91)$.

$2 \mathrm{ml}$

$\mathrm{p}, \mathrm{p}-\mathrm{DDE}=1.7 \mathrm{ppm}, \quad \mathrm{PCB} ' \mathrm{~s}=1.1 \mathrm{ppm}$
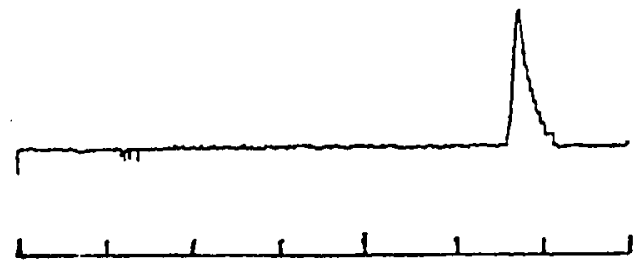

0 time (min)

7

Figure 56. Northern elephant seal (Mirounga angustirostris $)-(7 / 5 / 95)$.

$1 \mathrm{ml}$

$\mathrm{p}, \mathrm{p}-\mathrm{DDE}=1.1 \mathrm{ppm}, \quad \mathrm{PCB} ' \mathrm{~s}=\mathrm{ND}$ 


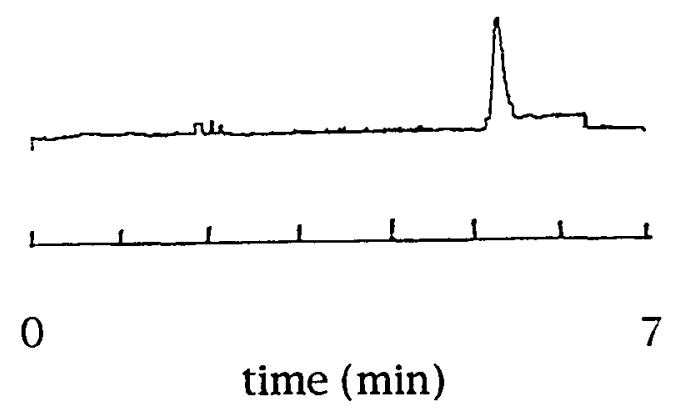

Figure 57. Harbor porpoise (Phocoena phocoena) - (4/15/95).

$$
2 \mathrm{ml}
$$

$\mathrm{p}, \mathrm{p}-\mathrm{DDE}=1.8 \mathrm{ppm}, \quad \mathrm{PCB} ' \mathrm{~s}=<1.6 \mathrm{ppm}$

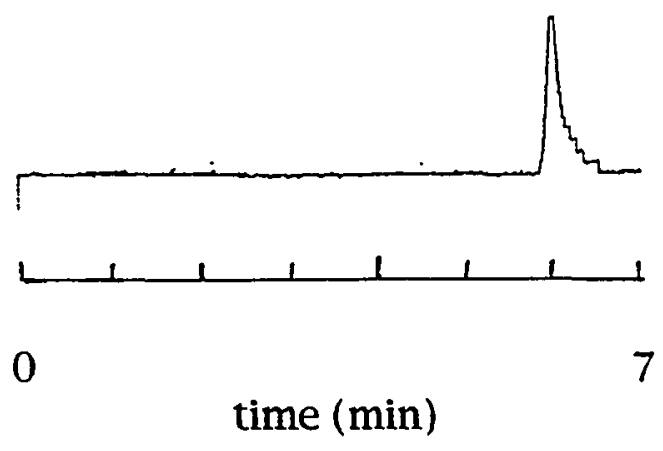

Figure 58. Harbor porpoise (Phocoena phocoena) - (6/21/95).

$1 \mathrm{ml}$

$\mathrm{p}, \mathrm{p}-\mathrm{DDE}=1.8 \mathrm{ppm}, \quad \mathrm{PCB} \mathrm{s}^{\prime}=\mathrm{ND}$ 


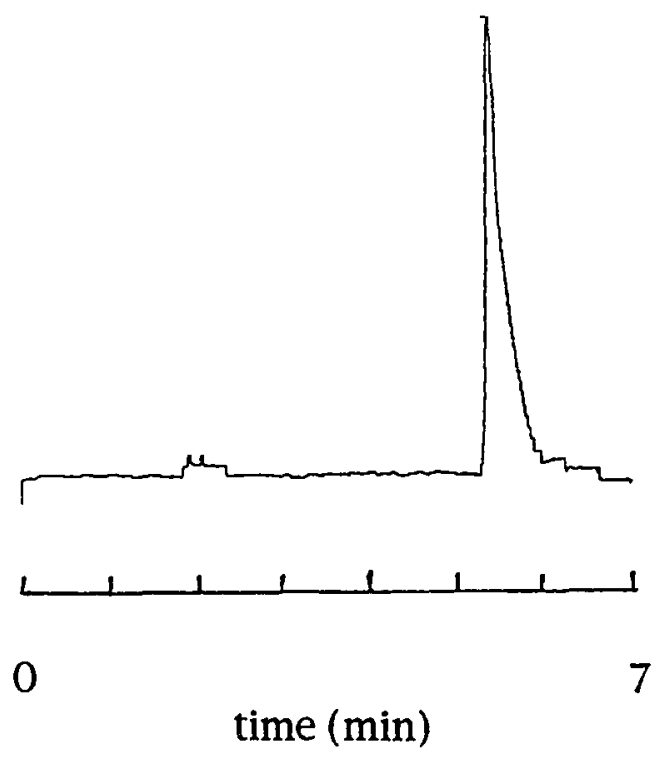

Figure 59. Harbor porpoise (Phocoena phocoena) - (10/27/95).

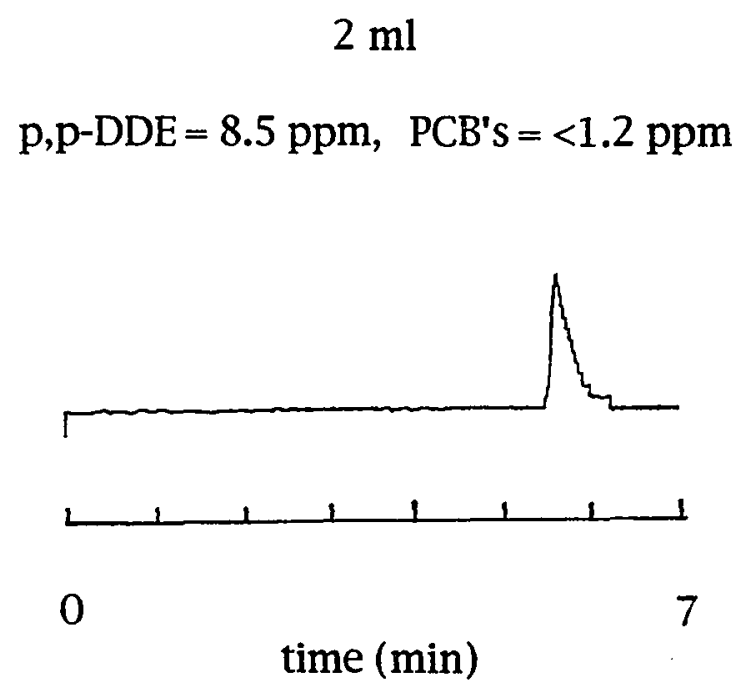

Figure 60. Harbor porpoise (Phocoena phocoena) - (12/11/95).

$1 \mathrm{ml}$

$$
\mathrm{p}, \mathrm{p}-\mathrm{DDE}=1.1 \mathrm{ppm}, \quad \mathrm{PCB}^{\prime} \mathrm{s}=\mathrm{ND}
$$




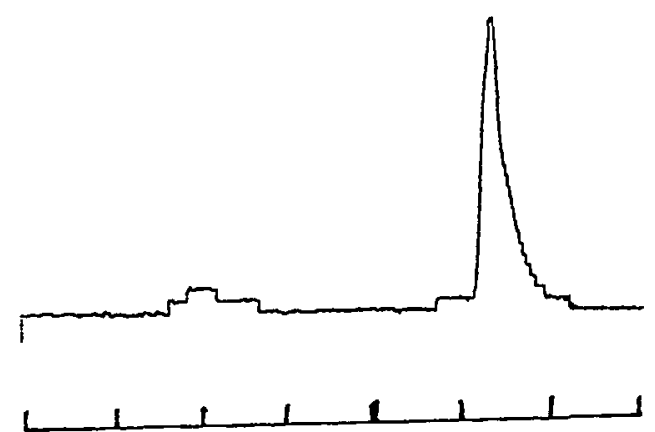

0 7

time (min)

Figure 61. Harbor porpoise (Phocoena phocoena) - (9/29/92).

$0.9 \mathrm{ml}$

$\mathrm{p}, \mathrm{p}-\mathrm{DDE}=3.0 \mathrm{ppm}, \quad \mathrm{PCB} \cdot \mathrm{s}=<0.5 \mathrm{ppm}$ 


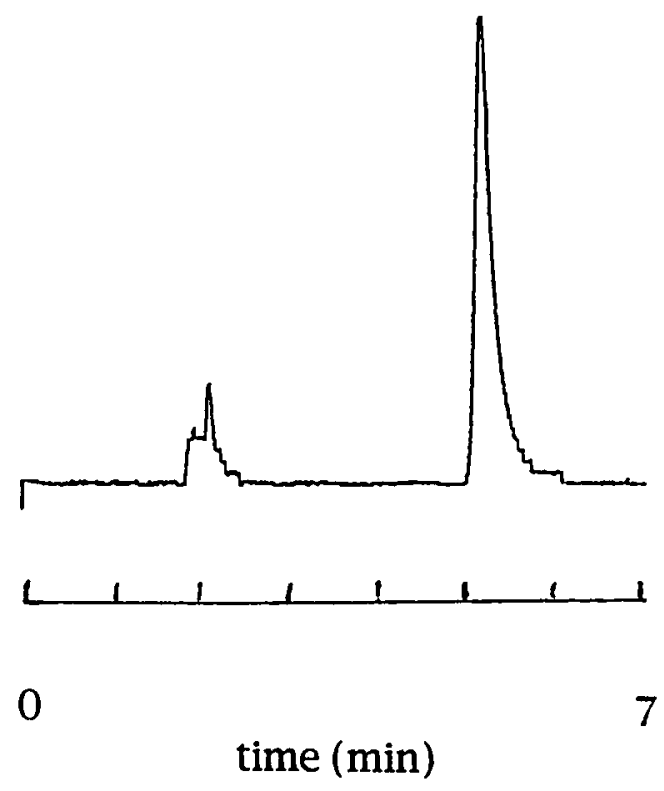

Figure 62. Harbor porpoise (Phocoena phocoena) - (5/6/93).

$$
2 \mathrm{ml}
$$

$$
\mathrm{p}, \mathrm{p}-\mathrm{DDE}=9.4 \mathrm{ppm}, \quad \text { PCB's }=13.2 \mathrm{ppm}
$$




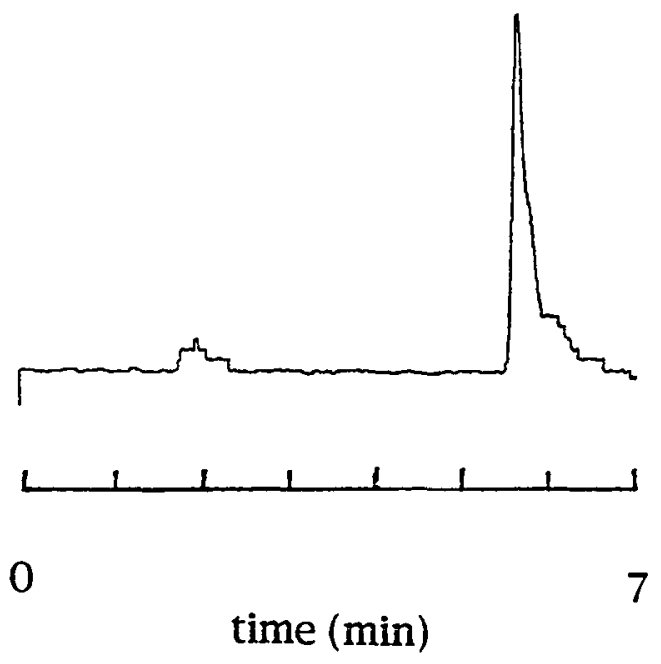

Figure 63. Harbor porpoise (Phocoena phocoena) - (4/11/94).

$2 \mathrm{ml}$

$\mathrm{p}, \mathrm{p}-\mathrm{DDE}=4.5 \mathrm{ppm}, \quad \mathrm{PCB} ' \mathrm{~s}=3.0 \mathrm{ppm}$ 


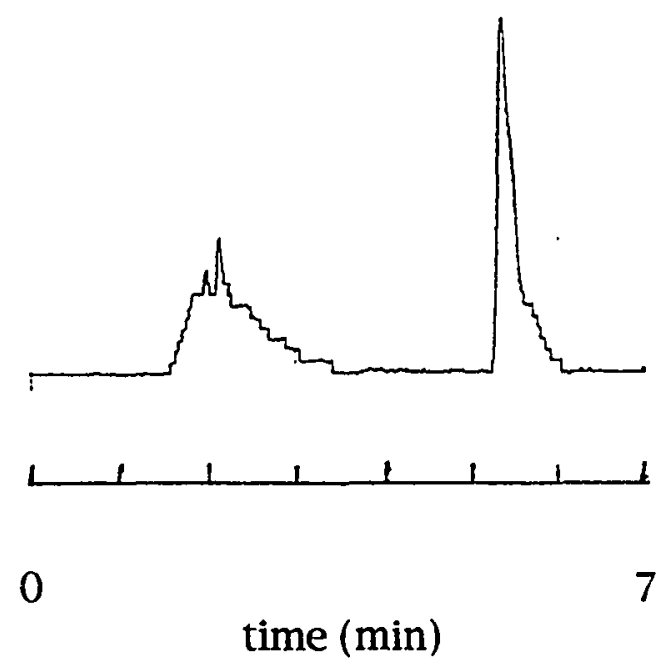

Figure 64. Harbor porpoise (Phocoena phocoena) - (4/15/95).

$$
2 \mathrm{ml}
$$

$\mathrm{p}, \mathrm{p}-\mathrm{DDE}=5.0 \mathrm{ppm}, \quad \mathrm{PCB} ' \mathrm{~s}=24.3 \mathrm{ppm}$ 


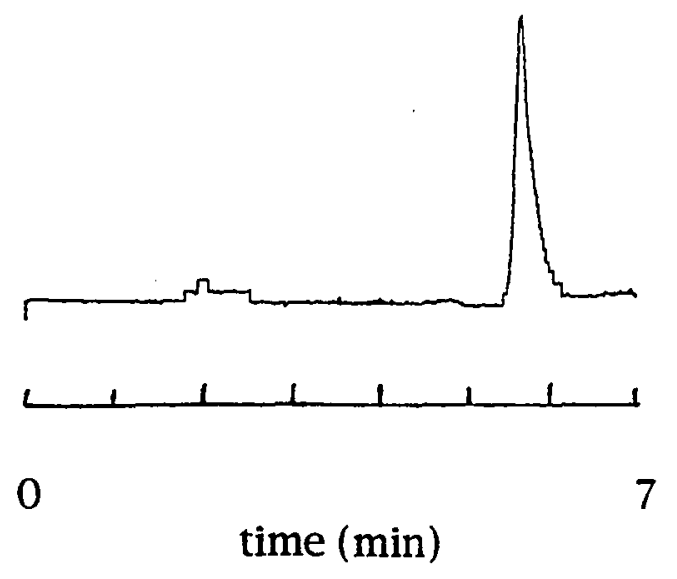

Figure 65. Harbor porpoise (Phocoena phocoena) - (1/13/96).

$1 \mathrm{ml}$

$$
\mathrm{p}, \mathrm{p}-\mathrm{DDE}=3.0 \mathrm{ppm}, \quad \mathrm{PCB} \mathrm{s}^{\prime}=<0.8 \mathrm{ppm}
$$

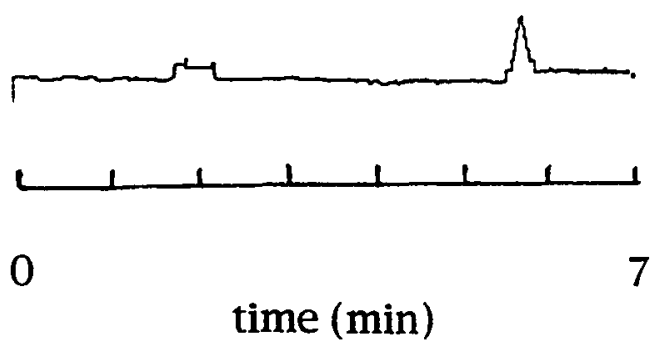

Figure 66. Harbor porpoise (Phocoena phocoena) - (7/1/92).

$$
1 \mathrm{ml}
$$

$$
\mathrm{p}, \mathrm{p}-\mathrm{DDE}=0.5 \mathrm{ppm}, \quad \mathrm{PCB}^{\prime} \mathrm{s}=<1.0 \mathrm{ppm}
$$



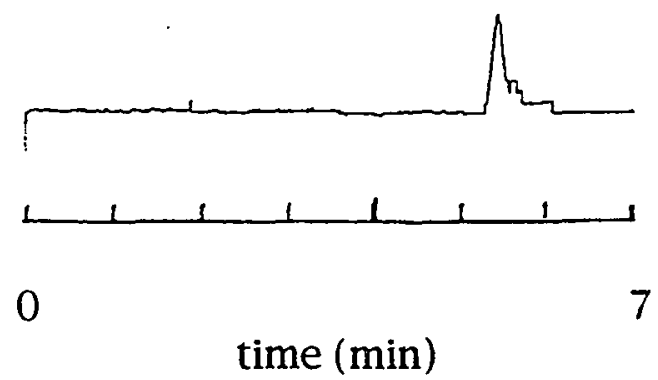

Figure 67. Harbor porpoise (Phocoena phocoena) - (7/23/95).

$$
\begin{gathered}
0.9 \mathrm{ml} \\
\mathrm{p}, \mathrm{p}-\mathrm{DDE}=0.5 \mathrm{ppm}, \quad \text { PCB's }=\mathrm{ND}
\end{gathered}
$$

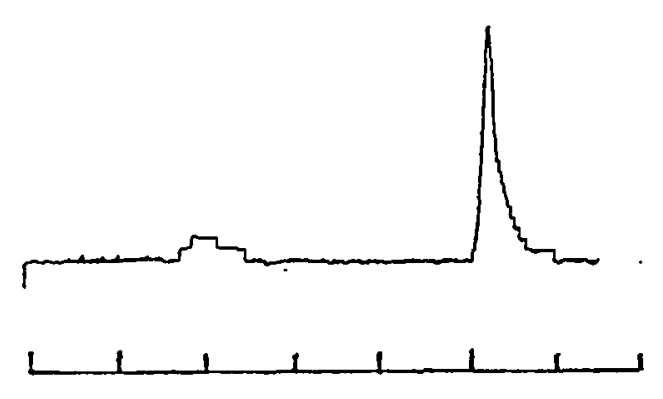

0

$$
\text { time ( } \min )
$$

Figure 68. Harbor porpoise (Phocoena phocoena) - (7/11/95).

$$
2 \mathrm{ml}
$$

$$
\mathrm{p}, \mathrm{p}-\mathrm{DDE}=4.1 \mathrm{ppm}, \quad \mathrm{PCB} \mathrm{s}=<1.2 \mathrm{ppm}
$$




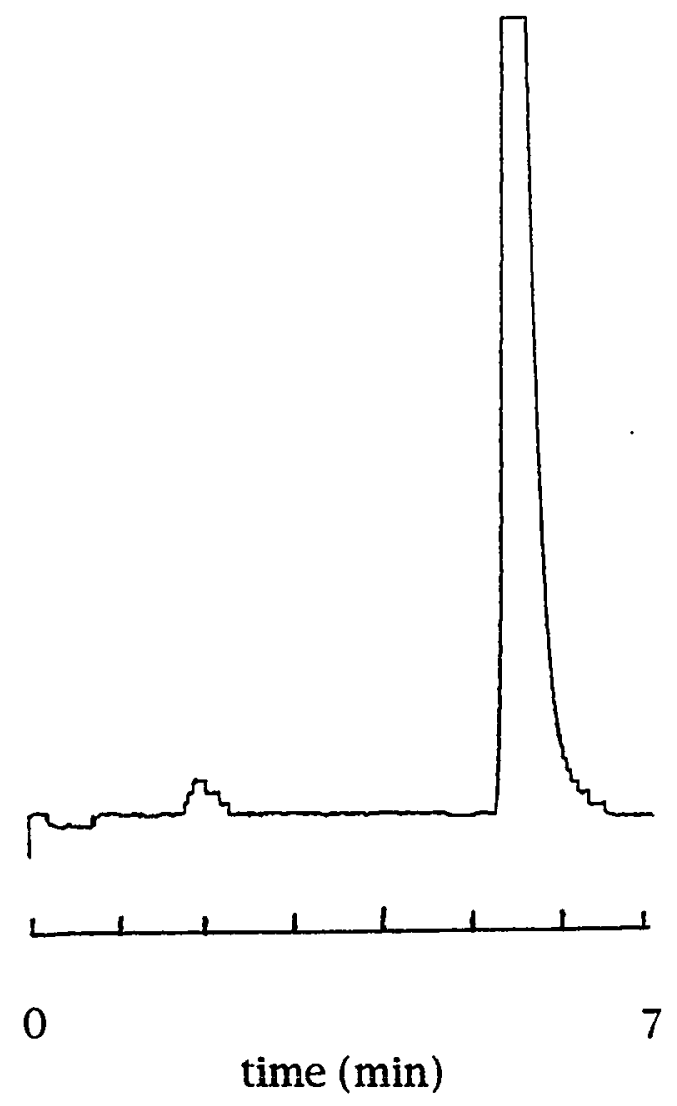

Figure 69. Common dolphin (Delphinus delphis) - (5/6/93).

$2 \mathrm{ml}$

$\mathrm{p}, \mathrm{p}-\mathrm{DDE}=53.9 \mathrm{ppm}, \quad \mathrm{PCB}{ }^{\prime} \mathrm{s}=6.1 \mathrm{ppm}$ 


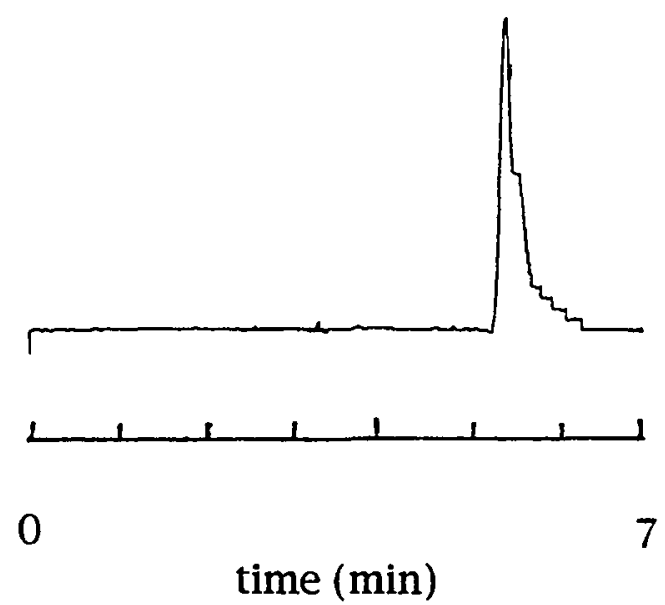

Figure 70. Common dolphin (Delphinus delphis) - (1994).

$2 \mathrm{ml}$

$$
\mathrm{p}, \mathrm{p}-\mathrm{DDE}=3.4 \mathrm{ppm}, \quad \mathrm{PCB} \cdot \mathrm{s}=\mathrm{ND}
$$




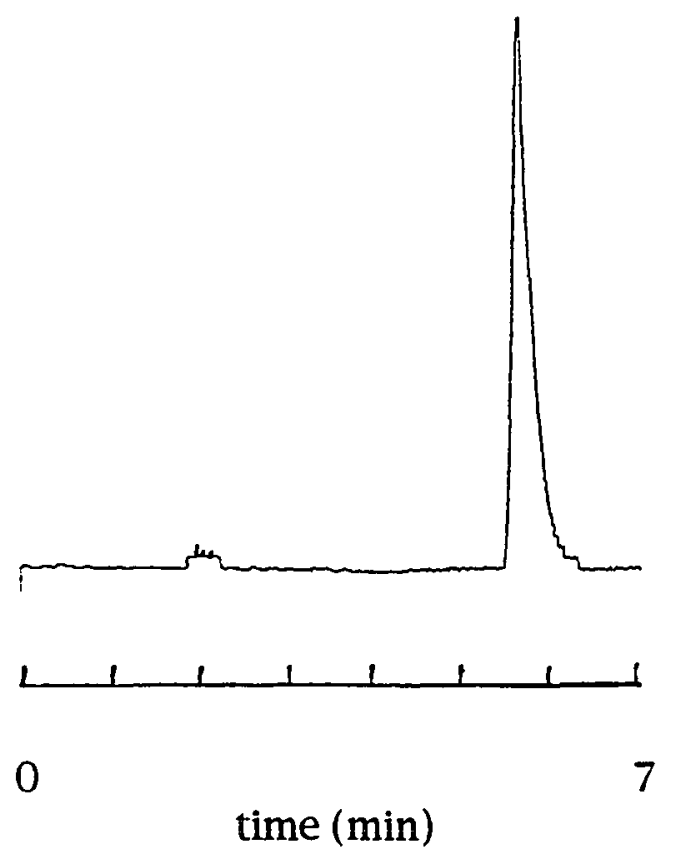

Figure 71. Common dolphin (Delphinus delphis) - (1/13/96).

$2 \mathrm{ml}$

$\mathrm{p}, \mathrm{p}-\mathrm{DDE}=11.5 \mathrm{ppm}, \quad \mathrm{PCB}{ }^{\prime} \mathrm{s}=<1.3 \mathrm{ppm}$ 


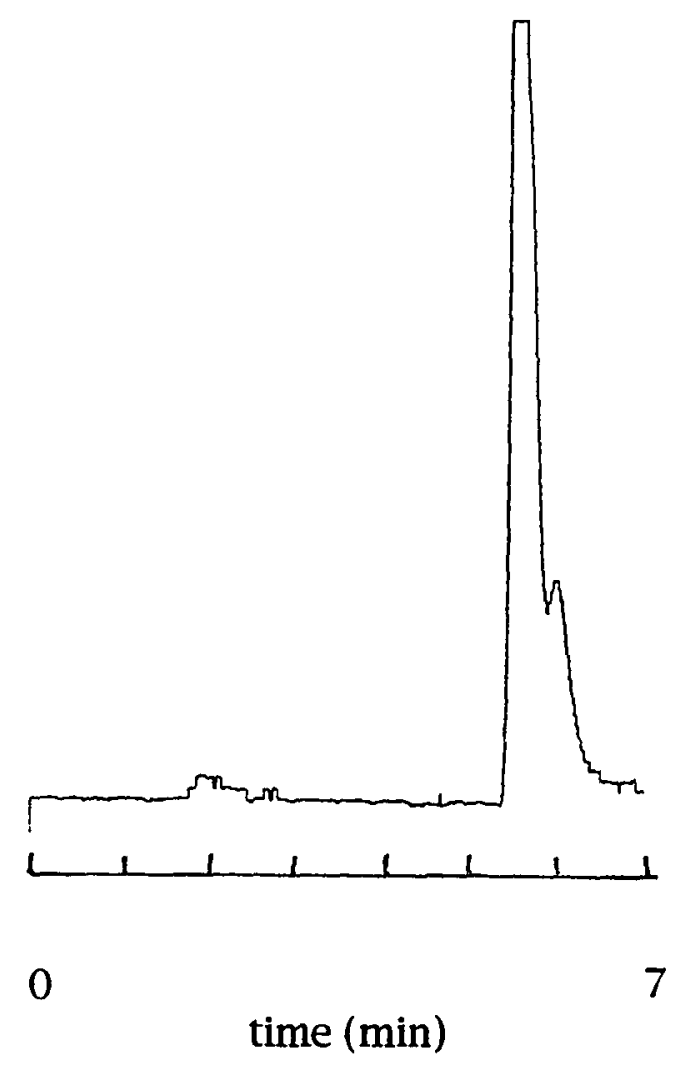

Figure 72. Striped dolphin (Stenella coeruleoalba) - (4/15/95).

$$
\begin{gathered}
2 \mathrm{ml} \\
\mathrm{p}, \mathrm{p}-\mathrm{DDE}=37.6 \mathrm{ppm}, \quad \mathrm{PCB}^{\prime} \mathrm{s}=5.9 \mathrm{ppm}
\end{gathered}
$$




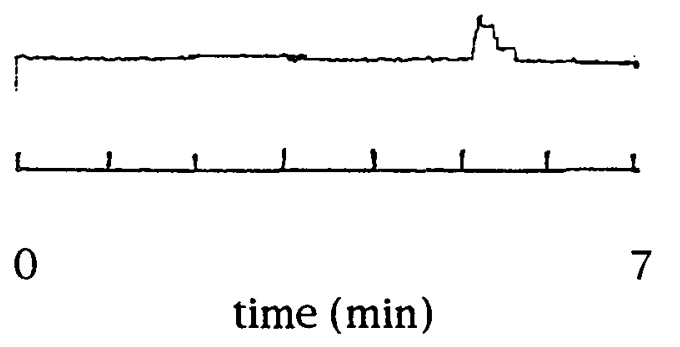

Figure 73. Bottlenose dolphin (Tursiops truncatus) $(2 / 25 / 93)$.

$$
\begin{gathered}
0.8 \mathrm{ml} \\
\mathrm{p}, \mathrm{p}-\mathrm{DDE}=0.4 \mathrm{ppm}, \quad \mathrm{PCB} \cdot \mathrm{s}=\mathrm{ND}
\end{gathered}
$$
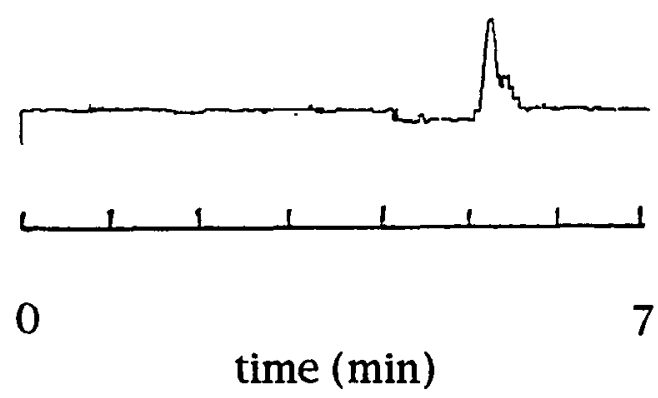

Figure 74. Dall's porpoise (Phocoenoides dalli) - (4/10/95).

$$
\begin{gathered}
2 \mathrm{ml} \\
\mathrm{p}, \mathrm{p}-\mathrm{DDE}=1.6 \mathrm{ppm}, \quad \text { PCB's }=\mathrm{ND}
\end{gathered}
$$




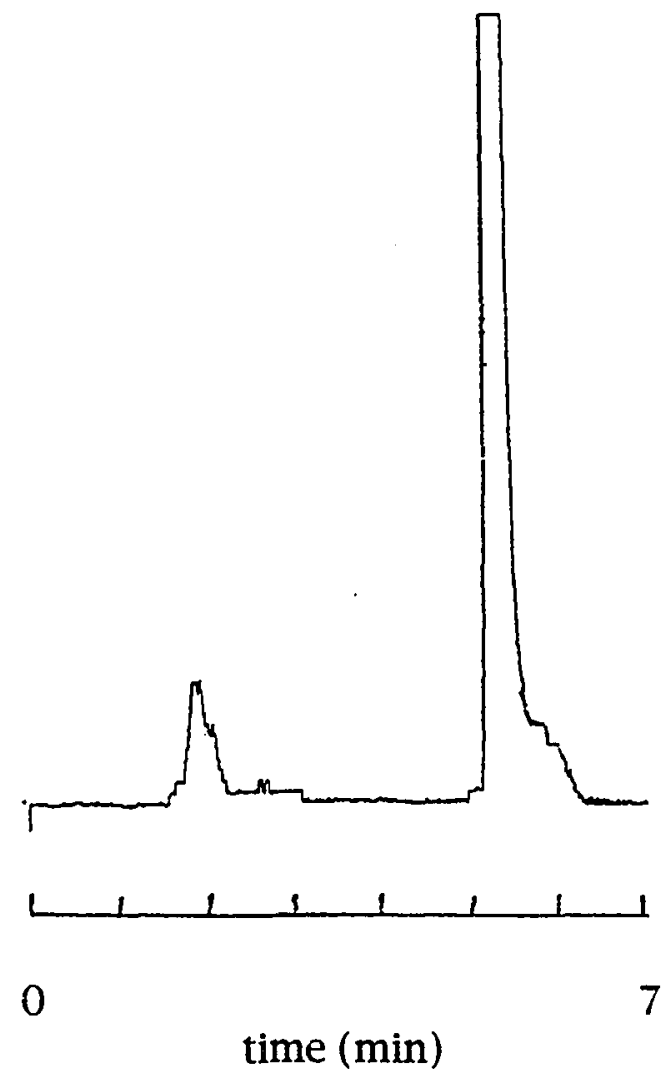

Figure 75. Risso's dolphin (Grampus griseus) - $(10 / 5 / 95)$.

$2 \mathrm{ml}$

$\mathrm{p}, \mathrm{p}-\mathrm{DDE}=44.5 \mathrm{ppm}, \quad \mathrm{PCB}^{\prime} \mathrm{s}=18.6 \mathrm{ppm}$ 


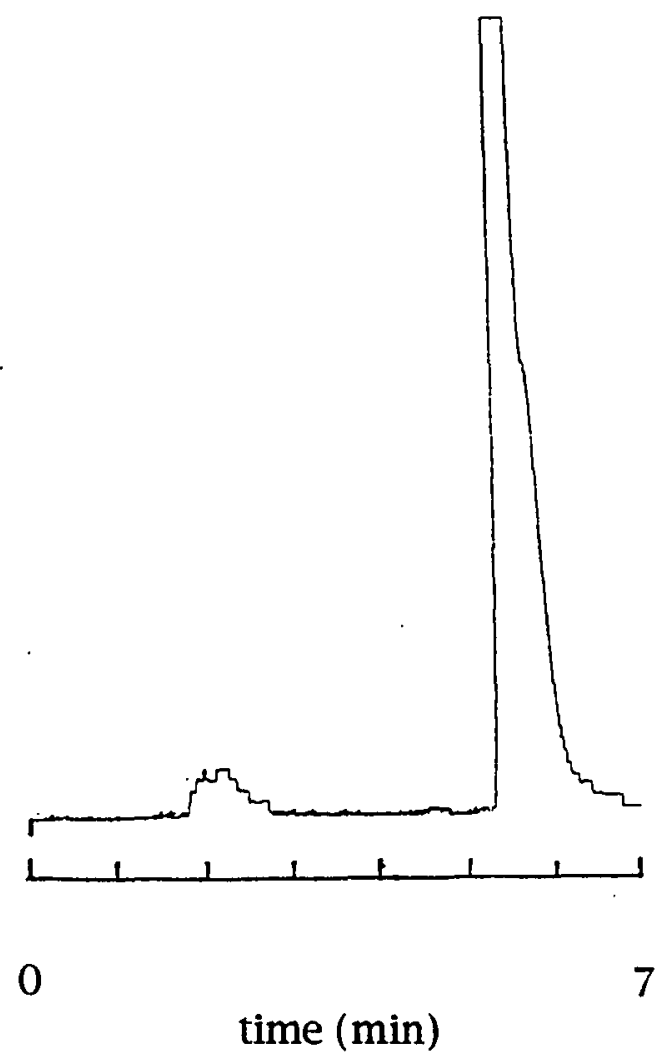

Figure 76. False killer whale (Pseudorca crassidens) - (10/8/93).

$2 \mathrm{ml}$

$\mathrm{p}, \mathrm{p}-\mathrm{DDE}=40.9 \mathrm{ppm}, \quad \mathrm{PCB} \cdot \mathrm{s}=10.5 \mathrm{ppm}$ 


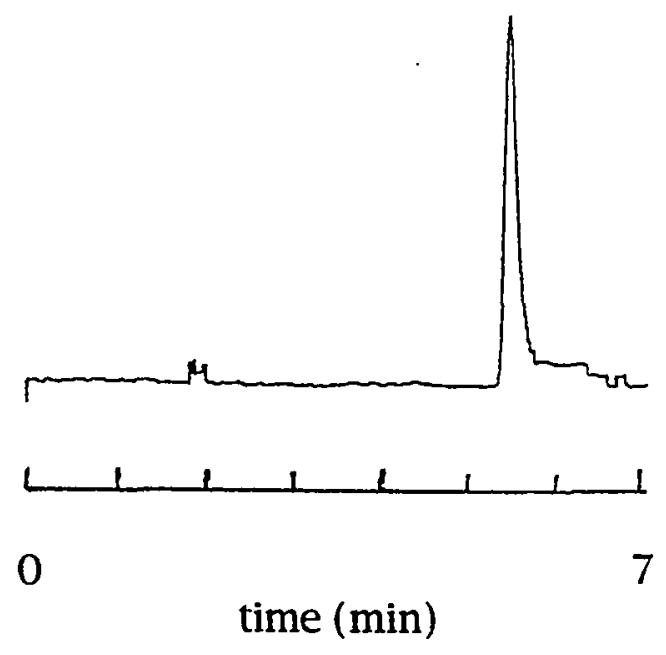

Figure 77. Stejneger's beaked whale (Mesoplodon stejnegeri) $(10 / 95)$.

$2 \mathrm{ml}$

$\mathrm{p}, \mathrm{p}-\mathrm{DDE}=3.8 \mathrm{ppm}, \quad \mathrm{PCB} \cdot \mathrm{s}=<0.9 \mathrm{ppm}$

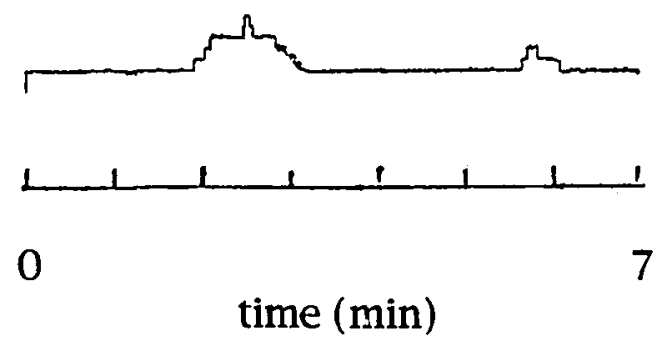

Figure 78. Minke whale (Balaenoptera acutorostrata) $(5 / 25 / 93)$.

$0.9 \mathrm{ml}$ $\mathrm{p}, \mathrm{p}-\mathrm{DDE}=<0.1 \mathrm{ppm}, \mathrm{PCB} \mathrm{s}=<0.6 \mathrm{ppm}$ 


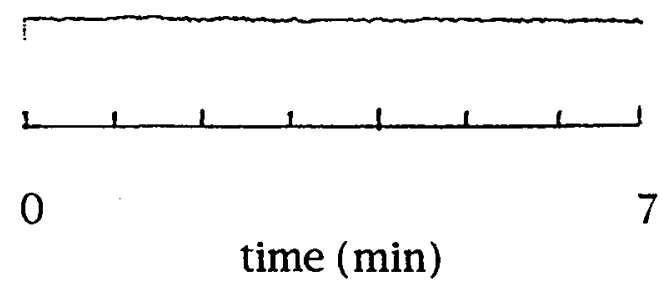

Figure 79. Walrus (Odobenus rosmarus) - (12/20/88).

$$
\begin{gathered}
1 \mathrm{ml} \\
\mathrm{p}, \mathrm{p}-\mathrm{DDE}=\mathrm{ND}, \mathrm{PCB}^{\prime} \mathrm{s}=\mathrm{ND}
\end{gathered}
$$

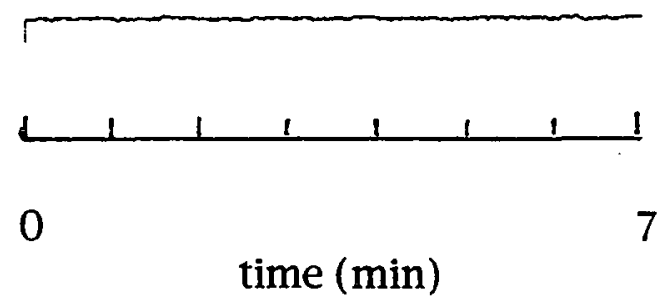

Figure 80. Polar bear (Ursus maritimus) - 10/18/95).

$$
\begin{gathered}
2 \mathrm{ml} \\
\mathrm{p}, \mathrm{p}-\mathrm{DDE}=\mathrm{ND}, \quad \mathrm{PCB}^{\prime} \mathrm{s}=\mathrm{ND}
\end{gathered}
$$




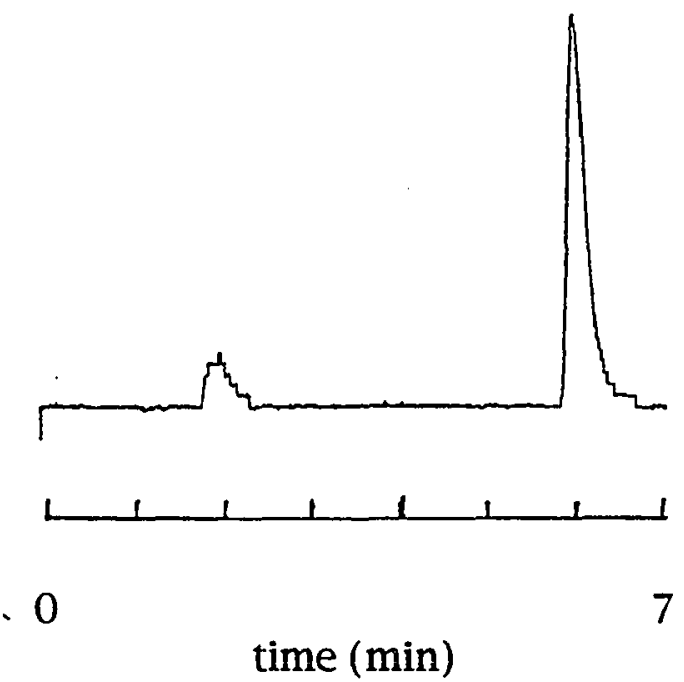

Figure 81. Bottlenose dolphin (Tursiops truncatus) - (7/7/91).

$2 \mathrm{ml}$

$$
\mathrm{p}, \mathrm{p}-\mathrm{DDE}=8.2 \mathrm{ppm}, \quad \mathrm{PCB}^{\prime} \mathrm{s}=9.9 \mathrm{ppm}
$$




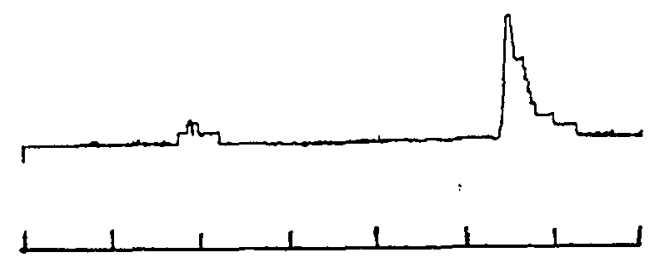

0

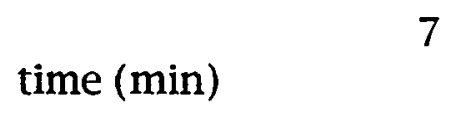

Figure 82. Bottlenose dolphin (Tursiops truncatus) - (5/3/92).

$0.8 \mathrm{ml}$

$$
\mathrm{p}, \mathrm{p}-\mathrm{DDE}=1.7 \mathrm{ppm}, \quad \mathrm{PCB} \mathrm{s}=1.3 \mathrm{ppm}
$$
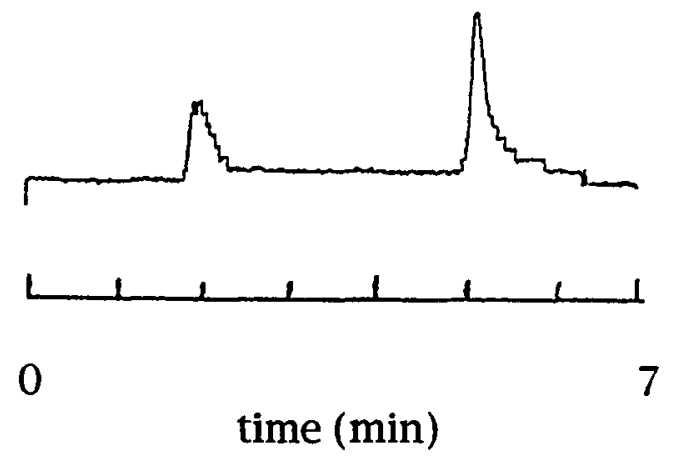

Figure 83. Bottlenose dolphin (Tursiops truncatus) - (1993).

$1 \mathrm{ml}$

$$
\mathrm{p}, \mathrm{p}-\mathrm{DDE}=1.4 \mathrm{ppm}, \quad \mathrm{PCB}^{\prime} \mathrm{s}=7.2 \mathrm{ppm}
$$




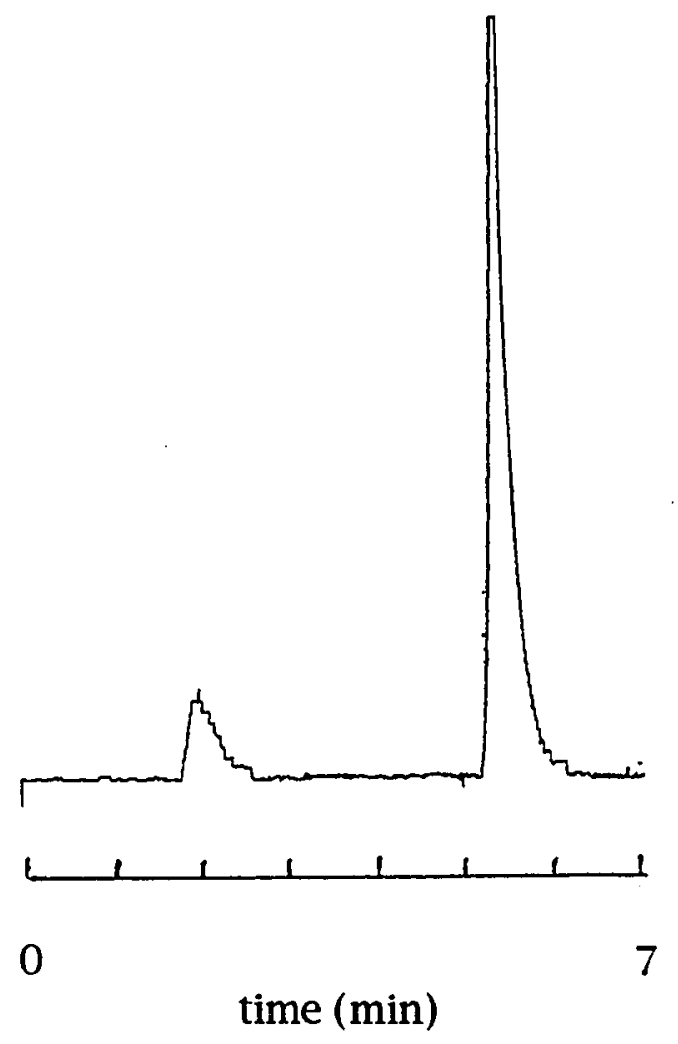

Figure 84. Short-finned pilot whale (Globicephala macrorhynchus) - (12/22/88).

$2 \mathrm{ml}$

$\mathrm{p}, \mathrm{p}-\mathrm{DDE}=17.2 \mathrm{ppm}, \quad \mathrm{PCB} \mathbf{s}=15.2 \mathrm{ppm}$ 


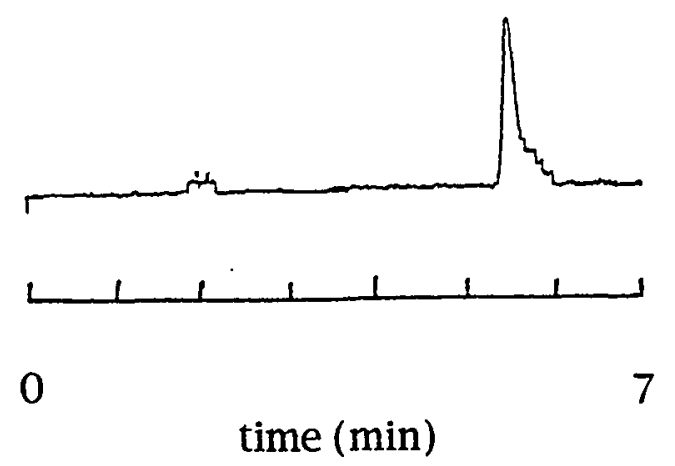

Figure 85. Short-finned pilot whale (Globicephala macrorhynchus) - (1993).

$1 \mathrm{ml}$

$\mathrm{p}, \mathrm{p}-\mathrm{DDE}=2.5 \mathrm{ppm}, \mathrm{PCB} ' \mathrm{~s}=<1.4 \mathrm{ppm}$ 


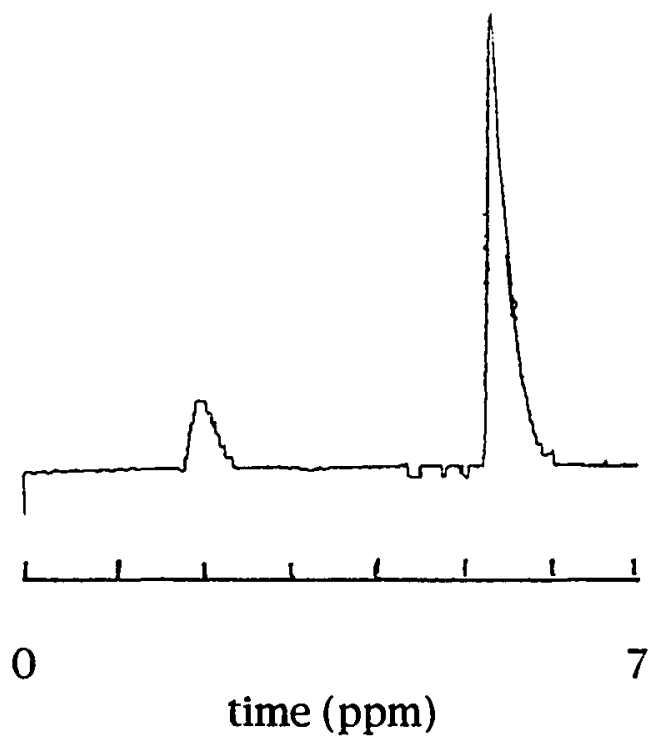

Figure 86. Commerson's dolphin (Cephalorhynchus commersonii) - (1983).

$2 \mathrm{ml}$

$\mathrm{p}, \mathrm{p}-\mathrm{DDE}=8.5 \mathrm{ppm}, \quad$ PCB's $=12.5 \mathrm{ppm}$ 


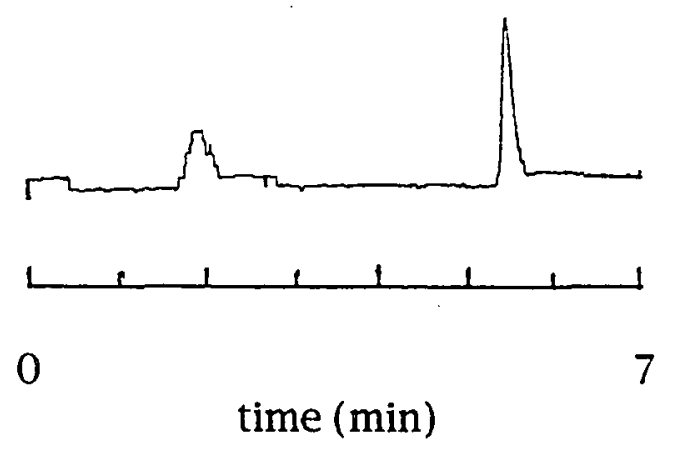

Figure 87. Commerson's dolphin (Cephalorhynchus commersonii) $-(5 / 7 / 91)$.

$2 \mathrm{ml}$

$\mathrm{p}, \mathrm{p}-\mathrm{DDE}=1.6 \mathrm{ppm}, \quad \mathrm{PCB}^{\prime} \mathrm{s}=7.0 \mathrm{ppm}$

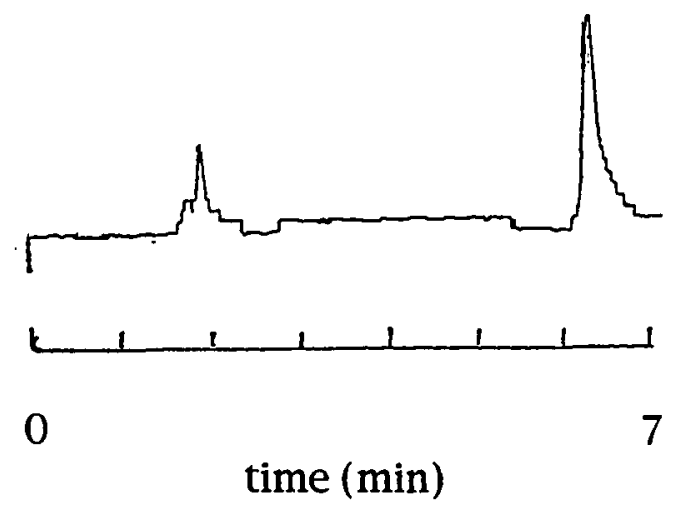

Figure 88. Pygmy sperm whale (Kogia breviceps) - (4/20/92).

$1 \mathrm{ml}$

$$
\mathrm{p}, \mathrm{p}-\mathrm{DDE}=1.8 \mathrm{ppm}, \quad \mathrm{PCB}^{\prime} \mathrm{s}=4.5 \mathrm{ppm}
$$




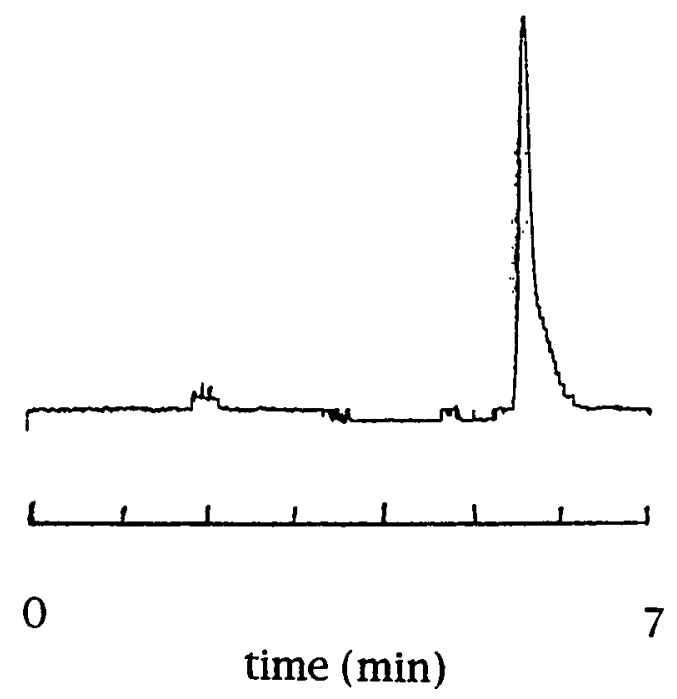

Figure 89. Pygmy sperm whale (Kogia breviceps) - (8/31/92).

$2 \mathrm{ml}$

$\mathrm{p}, \mathrm{p}-\mathrm{DDE}=6.6 \mathrm{ppm}, \quad \mathrm{PCB}^{\prime} \mathrm{s}=<1.3 \mathrm{ppm}$ 


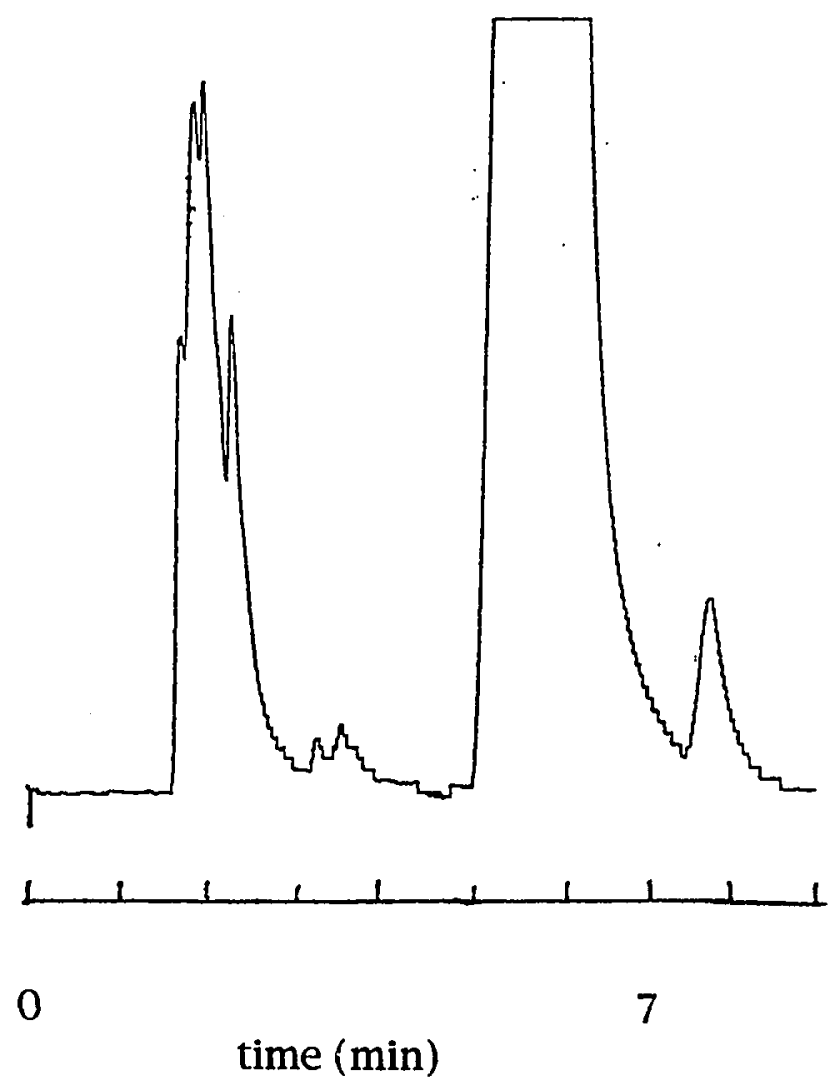

Figure 90. Killer whale ( Orcinus orca) - $(4 / 13 / 96)$.

$2 \mathrm{ml}$

$\mathrm{p}, \mathrm{p}-\mathrm{DDE}=494 \mathrm{ppm}, \quad \mathrm{PCB} \cdot \mathrm{s}=276 \mathrm{ppm}$ 


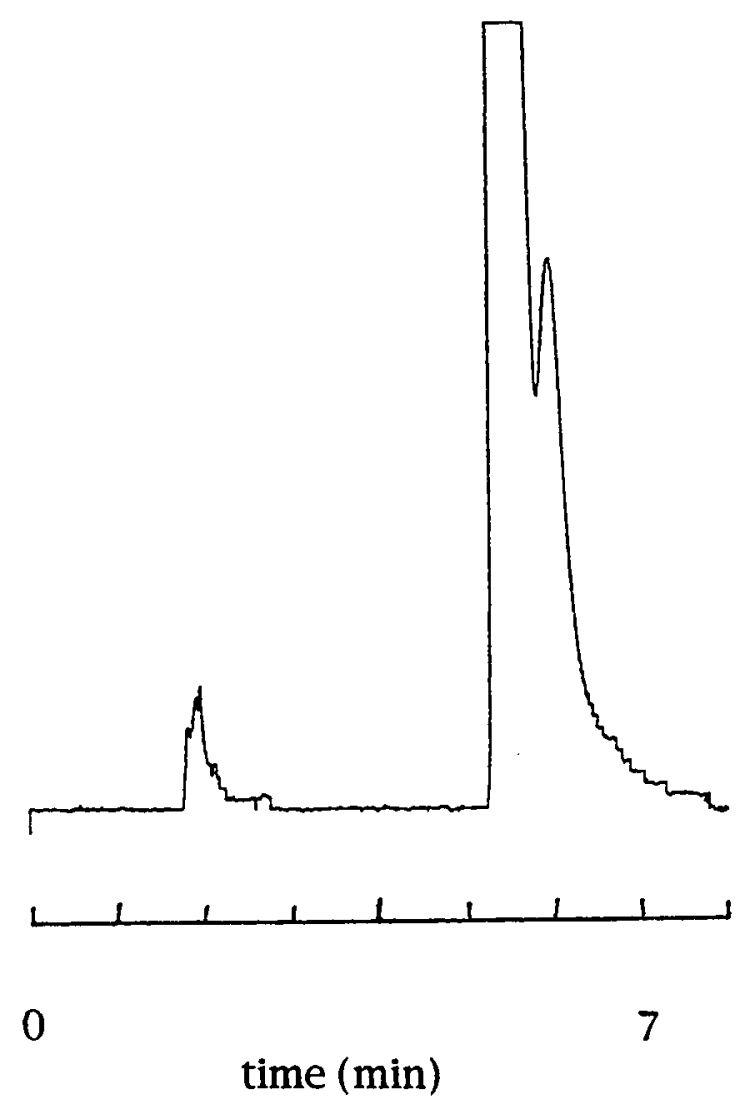

Figure 91. Killer whale (무inus orca) - (7/24/93).

$$
2 \mathrm{ml}
$$$$
\mathrm{p}, \mathrm{p}-\mathrm{DDE}=151 \mathrm{ppm}, \quad \mathrm{PCB}^{\prime} \mathrm{s}=19.5 \mathrm{ppm}
$$ 


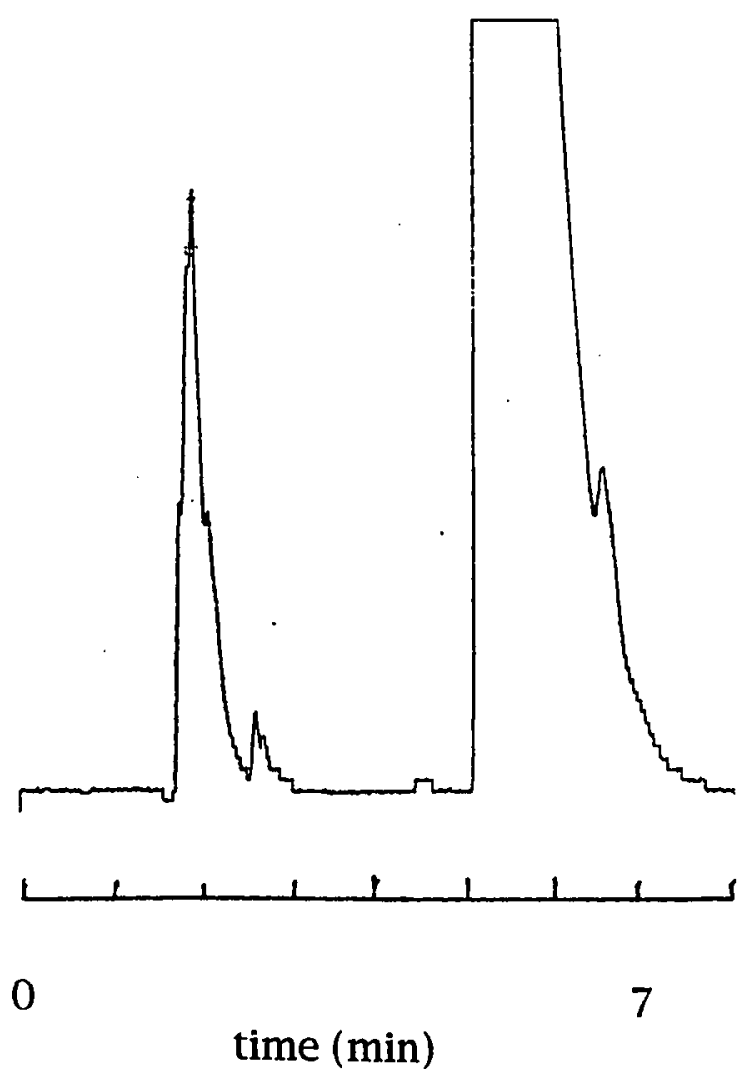

Figure 92. Killer whale ( $\underline{\text { Orcinus }}$ orca) $-(5 / 13 / 95)$.

$2 \mathrm{ml}$

$\mathrm{p}, \mathrm{p}-\mathrm{DDE}=519 \mathrm{ppm}, \quad \mathrm{PCB}^{\prime} \mathrm{s}=117 \mathrm{ppm}$ 


\section{BIBLIOGRAPHY}

Abbott, D.C. \& J. Thomson. 1965. The application of thin-layer chromatographic techniques to the analysis of pesticide residues. Residue Reviews. 11: 1-59.

Acree, Jr., F., Beroza, M. \& M.C. Bowman. 1963. Codistillation of DDT with water. Journal of Agricultural and Food Chemistry. 11(4): 278-280.

Addison, R.F. 1978. DDT degradation in trout: comparison with mammalian routes. Abstract, Fourth International Congress of Pesticide Chemistry (IUPAC), Zurich. V-522.

Addison, R.F. \& P.F. Brodie. 1973. Occurrence of DDT residues in beluga whales (Delphinapterus leucas) from the Mackenzie Delta, N.W.T. Journal of the Fisheries Research Board of Canada. 30(11): 1733-1736.

Addison, R.F. \& P.F. Brodie. 1977. Organochlorine residues in maternal blubber, milk, and pup blubber from grey seals (Halichoerus grypus) from Sable Island, Nova Scotia. Journal of the Fisheries Research Board of Canada. 34(7): 937-941.

Addison, R.F. \& T.G. Smith. 1974. Organochlorine residue levels in Arctic ringed seals: variation with age and sex. Oikos. 25: 335-337.

Addison, R.F. \& M.E. Zinck. 1986. PCB's have declined more than DDT-group residues in Arctic ringed seals (Phoca hispida) between 1972 and 1981. Environmental Science and Technology. 20(3): 253-256. 
Addison, R.F., Kerr, S.R., Dale, J. \& D.E. Sergeant. 1973. Variation of organochlorine residue levels with age in Gulf of St. Lawrence harp seals (Pagophilus groenlandicus). Journal of the Fisheries Research Board of Canada. 30(5): 595-600.

Agarwal, H.C., Yadav, D.V. \& M.K.K. Pillai. 1978. Metabolism of ${ }^{14} \mathrm{C}$-DDT in Pheretima posthuma and effect of pretreatment with DDT, lindane, and dieldrin. Bulletin of Environmental Contamination and Toxicology. 19: 295-299.

Aguilar, A. 1984. Relationship of DDE/tDDT in marine mammals to the chronology of DDT input into the ecosystem. Canadian Journal of Fisheries and Aquatic Sciences. 41(6): 840-844.

Aguilar, A. 1987. Using organochlorine pollutants to discriminate marine mammal populations: a review and critique of the methods. Marine Mammal Science. 3(3): 242-262.

Aguilar, A. \& A. Borrell. 1988. Age- and sex-related changes in organochlorine compound levels in fin whales (Balaenoptera physalus) from the eastern North Atlantic. Marine Environmental Research. 25: 195-211.

Aguilar, A. \& A. Borrell. 1994. Abnormally high polychlorinated biphenyl levels in striped dolphins (Stenella coeruleoalba) affected by the 1990-1992 Mediterranean epizootic. The Science of the Total Environment. 154: 237-247.

Aitzetmuller, K. 1975. Adsorption liquid chromatography of DDT and polychlorinated biphenyls. Journal of Chromatography. 107: 411-415.

Albro, P.W. \& L. Fishbein. 1972. Intestinal absorption of polychlorinated biphenyls in rats. Bulletin of Environmental Contamination and Toxicology. 8: 26-31.

Allen, J.R. \& D.A. Barsotti. 1976. The effects of transplacental and mammary movement of PCB's on infant Rhesus monkeys. Toxicology. 6(3): 331-340. 
Amico, V., Oriente, G., Piattelli, M. \& C. Tringali. 1979. Concentrations of PCB's, BHC's and DDT's residues in seaweeds from the east coast of Sicily. Marine Pollution Bulletin. 10: 177-179.

Anas, R.E. 1974. DDT plus PCB's in blubber of harbor seals. Pesticides Monitoring Journal. 8(1): 12-14.

Anas, R.E. \& A.J. Wilson, Jr. 1970. Organochlorine pesticides in fur seals. Pesticides Monitoring Journal. 3(4): 198-200.

Anderson, J.P.E. \& E.P. Lichtenstein. 1971. Effect of nutritional factors on DDT-degradation by Mucor alternans. Canadian Journal of Microbiology. 17: 1291-1298.

Anderson, D.W., Jehl,Jr., J.R., Risebrough, R.W., Woods, Jr., L.A., Deweese, L.R. \& W.G. Edgecomb. 1975. Brown pelicans: improved reproduction off the Southern California coast. Science. 190: 806-808.

Andersson, L., Nikolaidis, E., Brunstrom, B., Bergman, A. \& L. Dencker. 1991. Effects of polychlorinated biphenyls with Ah receptor affinity on lymphoid development in the thymus and the bursa of Fabricius chick embryos in ovo. Toxicology and Applied Pharmacology. 107:183-188.

Armour, J.A. \& J.A. Burke. 1970. Separating polychlorinated biphenyls from DDT and its analogues. Journal of the Assoication of Official Analytical Chemists. 53: 761-768.

Arndt, D.P. 1973. DDT and PCB levels in three Washington state harbor seal (Phoca vitulina richardii) populations. M.S. Thesis, University of Washington, Seattle.

Auerlich, R.J., Bursian, S.J., Breslin, W.J., Olsson, B.A. \& R.K. Ringer. 1985. Toxicological manifestation of $2,4,5,2^{\prime}, 4^{\prime}, 5^{\prime}-$, 2,3,6,2', $3^{\prime}, 6^{\prime}$ - and 3,4,5,3',4',5'-hexachlorobiphenyls and Aroclor 1254 in mink. Journal of Toxicology and Environmental Health. 15: 63-79. 
Backlin, B.M. \& A. Bergman. 1992. Morphological aspects on the reproductive organs in female mink (Mustela vison) exposed to polychlorinated biphenyls and fractions thereof. Ambio. 21(8): 596-601.

Backstrom, J., Hansson, E. \& S. Ullberg. 1965. Distribution of $\mathrm{C}^{14}$-DDT and $\mathrm{C}^{14}$-dieldrin in pregnant mice determined by whole-body autoradiography. Toxicology and Applied Pharmacology. 7(1): 90-96.

Bacon, C.E., Jarman, W.M. \& D.P. Costa. 1992. Organochlorine and polychlorinated biphenyl levels in pinniped milk from the Arctic, the Antarctic, California and Australia. Chemosphere. 24(6): 779-791.

Bacon, C.E., Jarman, W.M., Estes, J.A., Simon, M. \& R.J. Norstrom. 1995. Organochlorine compounds in sea otters (Enhydra Lutris) from California and Alaska. Abstract, Eleventh Biennial Conference on the Biology of Marine Mammals, Orlando, $\mathrm{Fl}$.

Baird, R.W., Langelier, K.M., \& P.J. Stacey. 1989. First records of false killer whales, Pseudorca crassidens, in Canada. Canadian Field-Naturalist. 103: 368-371.

Bagley, G.E. \& E. Cromartie. 1973. Elimination pattern of Aroclor 1254 components in the bobwhite. Journal of Chromatography. 75: 219-226.

Bailey, S. \& P.J. Bunyan. 1972. Interpretation of persistence and effects of polychlorinated biphenyls in birds. Nature. 236: 34-36.

Bakalyar, S.R. \& R.A. Henry. 1976. Variables affecting precision and accuracy in high-performance liquid chromatography. Journal of Chromatography. 126: 327-345.

Barker. R.J. 1958. Notes on some ecological effects of DDT sprayed on elms. Journal of Wildlife Management. 22(3): 269-274. 
Barrie, L., Gregor, D., Hargrave, B., Lake, R., Muir, D., Shearer, R., Tracey, B. \& T. Bidleman. 1992. Arctic contaminants: sources, occurrence, and pathways. The Science of the Total Environment. 122: 1-74.

Beckmen, K.B. \& J.W. Newman. 1993. Northern elephant seal skin disease: an investigation of a possible toxicological etiology. Abstract, Tenth Biennial Conference on the Biology of Marine Mammals, Galveston, Tx.

Beeton, A.M. 1979. Polychlorinated Biphenyls. Washington, DC: NAS.

Beland, P., De Guise, S. \& R. Plante. 1992. Toxicology and Pathology of St. Lawrence Marine Mammals, Project Report. Washington, DC: World Wildlife Fund.

Berg, G.G. 1969. Introduction: a view from the podium. In Chemical Fallout: Current Research on Persistent Pesticides, eds. M.W. Miller \& G.G. Berg., pp. xi-xvii. Springfield, Il.: Charles C. Thomas.

Bergman, A., Olsson, M. \& S. Reiland. 1992. Skull-bone lesions in the Baltic grey seal (Halichoerus grypus). Ambio. 21(8): 517-519.

Bergman, A., Nortstrom, R.J., Haraguchi, K., Kuroki, H. \& P. Beland. 1994. PCB and DDE methyl sulfones in mammals from Canada and Sweden. Environmental Toxicology and Chemistry. 13: 121-128.

Bidleman, T.F. \& C.E. Olney. 1974. Chlorinated hydrocarbons in the Sargasso Sea atmosphere and sea water. Science. 183: 516-518.

Bishara, R.H., Born, G.S. \& J.E. Christian. 1972. Thin-layer chromatography of DDT and some related compounds on aluminum oxide chromatoplates. Journal of Chromatography. 64: $135-145$. 
Biswas, R.K., Rao, A.R. \& V.S.N. Rao. 1981. Effect of feeding DDT on semen characteristics of rams. Indian Veterinary Journal. 58(8): 665-666.

Bitman, J. \& H.C. Cecil. 1970. Estrogenic activity of DDT analogs and polychlorinated biphenyls. Journal of Agricultural and Food Chemistry. 18(6): 1108-1112.

Bitman, J., Cecil, H.C., Harris, S.J. \& G.F. Fries. 1969. DDT induces a decrease in eggshell calcium. Nature. 224: 44-46.

Blomkvist, G., Roos, A., Bignert, A., Olsson, M. \& S Jensen. 1992. Concentrations of sDDT and PCB in seals from Swedish and Scottish waters. Ambio. 21(8): 539-545.

Blus, L.J. 1984. DDE in birds' eggs: comparison of two methods for estimating critical levels. Wilson Bulletin. 96(2): 268-276.

Blus, L.J., Henny, C.J., Kaiser, E. \& R.A. Grove. 1983. Effects on wildlife from the use of endrin in Washington State orchards. Transactions of the Forty-eighth North American Wildlife and Natural Resources Conference, pp. 159-174.

Bonner, W.N. 1990. The Natural History of Seals. New York: Facts on File.

Borrell, A. \& A. Aguilar. 1987. Variations in DDE percentage correlated with total DDT burden in the blubber of fin and sei whales. Marine Pollution Bulletin. 18(2): 70-74.

Borrell, A. \& A. Aguilar. 1991. Pollution by PCB's in striped dolphins affected by the western Mediterranean epizootic. In Proceedings of the Mediterranean Striped Dolphin Mortality International Workshop, eds. X. Pastor \& M. Simmonds, pp. 121-127. Madrid: Green Peace International. 
Bowes, G.W. \& C.J. Jonkel. 1975. Presence and distribution of polychlorinated biphenyls (PCB) in Arctic and Subarctic marine food chains. Journal of the Fisheries Research Board of Canada. 32(11): 2111-2123.

Bowman, M.C., Acree, Jr., F., Lofgren, C.S. \& M. Beroza. 1964. Chlorinated insecticides: fate in aqueous suspensions containing mosquito larvae. Science. 146: 1480-1481.

Brandt, I., Jonsson, C. \& B. Lund. 1992. Comparative studies on adrenocorticolytic DDT-metabolites. Ambio. 21(8): 602-605.

Briggs, S.A. 1992. Basic Guide to Pesticides. Washington, DC: Taylor \& Francis.

Brinkman, U.A.Th., Seetz, J.W.F.L. \& H.G.M. Reymer. 1976 a. High-speed liquid chromatography of polychlorinated biphenyls and related compounds. Journal of Chromatography. 116: 353-363.

Brinkman, U.A.Th., de Kok, A., de Vries, G. \& H.G.M. Reymer. 1976b. High-speed liquid and thin-layer chromatography of polychlorinated biphenyls. Journal of Chromatography. 128: $101-110$.

Brooks, G.T. 1974. Chlorinated Insecticides: Technology and Application. Cleveland: CRC Press.

Brooks, G.T. \& A. Harrison. 1965. Structure-activity relationships among insecticidal compounds derived from chlordene. Nature. 205: 1031-1032.

Brooks, G.T., Harrison, A. \& J.T. Cox. 1963. Significance pf the epoxidation of the isomeric insecticides aldrin and isodrin by the adult housefly in vivo. Nature. 197: 311-312.

Brouwer, A., Reijnders, P.J.H. \& J.H. Koeman. 1989. Polychlorinated biphenyl (PCB)-contaminated fish induces vitamin $\mathrm{A}$ and thyroid hormone deficiency in the common seal (Phoca vitulina). Aquatic Toxicology. 15: 99-106. 
Brown, A.W.A. 1978. Ecology of Pesticides. New York: John Wiley.

Brown, A.W.A. \& R. Pal. 1971. Insecticide Resistance in Arthropods. Geneva: WHO.

Brunstrom, B. 1992. Induction of cytochrome P-450-dependent enzyme activities in female mink (Mustela vison) and their kits by technical PCB preparations and fractions thereof. Ambio. 21(8): 585-587.

Buckley, E.H. 1982. Accumulation of airborne polychlorinated biphenyls in foliage. Science. 216: 520-522.

Buhler, D.R., Claeys, R.R. \& B.R. Mate. 1975. Heavy metal and chlorinated hydrocarbon residues in California sea lions (Zalophus californianus californianus). Journal of the Fisheries Research Board of Canada. 32(12): 2391-2397.

Bunyan, P.J. \& P.I. Stanley. 1983. The environmental cost of pesticide usage in the United Kingdom. Agriculture Ecosystems and Environment. 9(2): 187-209.

Burnett, R. 1971. DDT residues: distribution of concentrations in Emerita analoga (Stimpson) along coastal California. Science. 174: 606-608.

Calambokidis, J. \& J. Barlow. 1991. Chlorinated hydrocarbon concentrations and their use for describing population discreteness in harbor porpoises from Washington, Oregon, and California. In Marine Mammal Strandings in the United States: Proceedings of the Second Marine Mammal Stranding Workshop, eds. J.E. Reynolds III \& D.K. Odell., pp. 101-110. NOAA Technical Report NMFS 98. Rockville, Md: NTIS.

Calambokidis, J. \& J. Francis. 1994. Marine Mammal Exposure to $\underline{P C B}$ and DDT Contamination in the Southern California Bight. Olympia, Wa.: Cascadia Research. 
Calambokidis, J. \& R.J. Peard. 1985. Chlorinated hydrocarbons in the tissues of northern fur seals from St. Paul Island, Alaska. In Fur Seal Investigations, 1982, ed. P. Kozloff. NOAA Technical Memorandum NMFS F/NWC-71. Rockville, Md: NTIS.

Calambokidis, J., Langelier, K.M., Stacey, P.J. \& R.W. Baird. 1990. Environmental contaminants in killer whales from Washington, British Columbia and Alaska. Abstract, Third International Orca Symposium, Victoria, BC.

Calambokidis, J., Peard, J., Steiger, G., Cubbage, J. \& R.L. DeLong. 1984. Chemical Contaminants in Marine Mammals from Washington State. NOAA Technical Memorandum NOS OMS6. Rockville, Md.: NTIS.

Carson, R. 1962. Silent Spring. Boston: Houghton Mifflin.

Carter, F.L. \& C.A. Stringer. 1970. Soil moisture and soil type influence initial penetration by organochlorine insecticides. Bulletine of Environmental Contamination and Toxicology. 5: 422-428.

Cherrington, A.D., Paim, U. \& O.T. Page. 1969. In vitro degradation of DDT by intestinal contents of Atlantic salmon (Salmo salar). Journal of the Fisheries Research Board of Canada. 26(1): 47-54.

Chiosi, S., Evidente, A., Randazzo, G. \& D. Scalorbi. 1982. Analysis of a mixture of polychlorinated biphenyls, DDT and its analogues by high-performance liquid chromatography. Journal of Liquid Chromatography. 5(9): 1653-1663.

Chiras, D.D. 1994. Environmental Science: Action for a Sustainable Future. Redwood City, Ca.: Benjamin Cummings. 
Claeys, R.R., Caldwell, R.S., Cutshall, N.H. \& R. Holton. 1975. Chlorinated pesticides and polychlorinated biphenyls in marine species, Oregon/Washington coast, 1972. Pesticides Monitoring Journal. 9(1): 2-10.

Clark, Jr., D.R. 1981. Bats and Environmental Contaminants: A Review. Special Scientific Report No. 235. Washington DC: USFWS.

Clark, Jr., D.R., Clawson, R.L. \& C.J. Stafford. 1983. Gray bats killed by dieldrin at two additional Missouri caves: aquatic macroinvertebrates found dead. Bulletin of Environmental Contamination and Toxicology. 30(2): 214-218.

Clausen, J., Braestrup, L. \& O. Berg. 1974. The content of polychlorinated hydrocarbons in Arctic mammals. Bulletin of Environmental Contamination and Toxicology. 12: $529-534$.

Clesceri, L. 1980. Case history: PCB's in the Hudson River. In Introduction to Environmental Toxicology, eds. F.E. Guthrie \& J.J. Perry, pp. 227-235. New York: Elsevier.

Cliath, M.M. \& W.F. Spencer. 1972. Dissipation of pesticides from soil by volatilization of degradation products: 1 . lindane and DDT.Envrionmental Science and Technology. 6(10): 910-914.

Cockcroft, V.G., de Kock, A.C., Lord, D.A. \& G.J.B. Ross. 1989. Organochlorines in bottlenose dolphins Tursiops truncatus from the east coast of South Africa. South African Journal of Marine Science. 8: 207-217.

Cohen, J.M. \& C. Pinkerton. 1966. Widespread translocation of pesticides by air transport and rain-out. Advances in Chemistry Series. 60:163-176.

Collins, G.B., Holmes, D.C. \& F.J. Jackson. 1972. The estimation of polychlorobiphenyls. Journal of Chromatography. 71: 443449. 
Connell, D. \& G. Miller. 1984. Chemistry and Ecotoxicology of Pollution. New York: John Wiley.

Conney, A.H. 1967. Pharmacological implications of microsomal enzyme induction. Pharmacological Reviews. 19(3): 317-366.

Cook, J.W. 1972. Chemical aspects of polychlorinated biphenyls (PCB's). Environmental Health Perspectives. 1: 3-13.

Cooke, A.S. 1973. Shell thinning in avian eggs by environmental pollutants. Environmental Pollution. 4(2): 85-152.

Corbet, G.B. \& J.E. Hill. 1986. A World List of Mammalian Species. New York: Facts on file.

Cory, L., Fjeld, P. \& W. Serat. 1971. Environmental DDT and the genetics of natural populations. Nature. 229: 128-130.

Cotham, W.E. \& T.F. Bidleman. 1991. Estimating the deposition of organic contaminants to the Arctic. Chemosphere. 22: $165-188$.

Crowe, M. 1995. Troubled waters. Audubon. 97(4): 14-16.

Culotta, E. 1995. New evidence about feminized alligators. Science. 267: 330-331.

Cunningham, W.P. \& B.W. Saigo. 1992. Environmental Science: A Global Concern. Dubuque, Ia.: Wm. C. Brown.

Davis, D. \& S. Safe. 1988. Immunosuppressive activities of polychlorinated dibenzofuran congeners: quantitative structure-activity relationships and interactive effects. Toxicology and Applied Pharmacology. 94: 141-149.

de Faubert Maunder, M.J., Egan, H., Godly, E.W., Hammond, E.W., Roburn, J. \& J. Thomson. 1964. Clean-up of animal fats and dairy products for the analysis of chlorinated pesticide residues. Analyst. 89: 168-174. 
De Guise, S., Lagace, A. \& P. Beland. 1994. True hermaphroditism in a St. Lawrence beluga whale (Delphinapterus leucas). Journal of Wildlife Diseases. 30: 287-290.

De Guise, S., Lagace, A., Beland, P., Girard, C. \& R. Higgins. 1995a. Non-neoplastic lesions in beluga whales (Delphinapterus leucas) and other marine mammals from the St. Lawrence estuary. Journal of Comparative Pathology. 112: 257-271.

De Guise, S., Martineau, D., Beland, P. \& M. Fournier. 1995b. Possible mechanisms of action of environmental contaminants on St. Lawrence beluga whales (Delphinapterus leucas). Environmental Health Perspectives. 103(4): 73-77.

Deichmann, W.B., MacDonald, W.E., Beasley, A.G. \& D. Cubit. 1971. Subnormal reproduction in beagle dogs induced by DDT and aldrin. Industrial Medicine and Surgery. 40(2): 10-20.

de Kock, A.C., Best, P.B., Cockcroft, V. \& C. Bosma. 1994. Persistent organochlorine residues in small cetaceans from the east and west coasts of southern Africa. The Science of the Total Environment. 154: 153-162.

Delong, R.L., Gilmartin, W.G. \& J.G. Simpson. 1973. Premature births in California sea lions: association with high organochlorine pollutant residue levels. Science. 181: 1168-1170.

Demeter, J. \& A. Heyndrickx. 1979. Selection of a high performance liquid chromatographic cleanup procedure for the determination of organochlorine pesticides in fatty biological extracts. Veterinary and Human Toxicology. 21: 151-155. 
Dempster, J. 1975. Effects of organochlorine insecticides on animal populations. In Organochlorine Insecticides: Persistent Organic Pollutants, ed. F. Moriarty, pp. 231-248. London: Academic Press.

de Swart, R., Ross, P.S., Vedder, L.J., Timmerman, H.H., Heisterkamp, S., Van Loveren, H., Vos, J.G., Reijnders, P.J.H. \& A.D.M.E. Osterhaus. 1994. Impairment of immune function in harbor seals (Phoca vitulina) feeding on fish from polluted waters. Ambio. 23(2): 155-159,

Dietz, R., Ansen, C.T., Have, P. \& M.P. Heide-Jorgensen. 1989. Clue to seal epizootic? Nature. 338: 627.

Dikshith, T.S.S. 1991a. Pesticides. In Toxicology of Pesticides in Animals, ed. T.S.S. Dikshith, pp. 1-39. Boca Raton, Fl.: CRC Press.

Dikshith, T.S.S. 1991b. Neurotoxicity of pesticides. In Toxicology of Pesticides in Animals, ed. T.S.S. Dikshith, pp. 171-181. Boca Raton, Fl.: CRC Press.

Dikshith, T.S.S. 1991c. Hepatotoxic effects of pesticides. In Toxicology of Pesticides in Animals, ed. T.S.S. Dikshith, pp. 147-169. Boca Raton, Fl.: CRC Press.

Dolan, J.W. \& J.N. Seiber. 1977. Chlorine-selective detection for liquid chromatography with a Coulson electrolytic conductivity detector. Analytical Chemistry. 49(2): 326-331.

Donkin, P., Mann, S.V. \& E.I. Hamilton. 1981. Polychlorinated biphenyl, DDT and dieldrin residues in grey seal (Halichoerus grypus)males, females and mother-foetus pairs sampled at the Farne Islands, England, during the breeding season. The Science of the Total Environment. 19: 121-142.

Drescher, H.E., Harms, U. \& E. Huschen beth. 1977. Organochlorines and heavy metals in the harbour seal Phoca vitulina from the German North Sea coast. Marine Biology. 41: 99-106. 
Duinker, J. 1985. Estuarine processes and riverborne pollutants. In Pollutants and Their Ecotoxicological Significance, ed. H.W. Nurnberg, pp. 227-238. Chichester, Eng.: John Wiley.

Duinker, J.C. \& M.Th.J. Hillebrand. 1979. Mobilization of organochlorines from female lipid tissue and transplacental transfer to fetus in a harbour porpoise (Phocoena phocoena) in a contaminated area. Bulletin of Environmental Contamination and Toxicology. 23: 728-732.

Duinker, J.C., Hillebrand, M.Th.J. \& R.F. Nolting. 1979. Organochlorines and metals in harbour seals (Dutch Wadden Sea). Marine Pollution Bulletin. 10: 360-364.

Durham, W.F., Ortega, P. \& W.J. Hayes, Jr. 1963. The effect of various dietary levels of DDT on liver function, cell morphology, and DDT storage in the Rhesus monkey. Archives of International Pharmacodynamics. 141: 111-129.

Eberhardt, L.L., Meeks, R.L. \& T.J. Peterle. 1971. Food chain model for DDT kinetics in a freshwater marsh. Nature. 230: 60-62.

Edqvist, L., Madej, A. \& M. Forsberg. 1992. Biochemical blood parameters in pregnant mink fed PCB and fractions of PCB. Ambio. 21(8): 577-581.

Edwards, C.A. 1970. Persistent pesticides in the environment. Critical Reviews in Environmental Control. 1(2): 7-67.

Eis, D. 1989. Simplification in the etiology of recent seal deaths. Ambio. 18(2): 144.

Eisenbeiss, F. \& H. Sieper. 1973. The potential use of highperformance liquid chromatography in residue analysis. Journal of Chromatography. 83: 439-446.

Eisler, R. 1986. Polychlorinated Biphenyl Hazards to Fish, Wildlife and Invertebrates: A Synoptic Review. USFWS Contamination Hazard Review Report No. 7. Rockville, Md.: NTIS. 
Ellis, D.H., DeWeese, L.R., Grubb, T.G., Kiff, L.F., Smith, D.G., Jarman, W.M. \& D.B. Peakall. 1989. Pesticide residues in Arizona peregrine falcon eggs and prey. Bulletin of Environmental Contamination and Toxicology. 42(1): 57-64.

Fang, S.C., Fallin, E. \& V.H. Freed. 1977. Maternal transfer of ${ }^{14} \mathrm{C}-\mathrm{p}, \mathrm{p}-\mathrm{DDT}$ via placenta and milk and its metabolism in rats. Archives of Environmental Contamination and Toxicology. 5: 427-436.

FDA. 1970. Chemistry and Toxicology of Polychlorinated Biphenyls or Aroclors. U.S. Food and Drug Administration Status Report June 1, 1970. Washington, DC: USDHEW.

Fehringer, N.V. \& J.E. Westfall. 1971. Separation and identification of DDT analogs in the presence of polychlorinated biphenyl compounds by two-dimensional thin-layer chromatography. Journal of Chromatography. 57: 397-405.

Fishbein, L. 1972. Chromatographic and biological aspects of polychlorinated biphenyls. Journal of Chromatography. 68: 345-426.

Fishbein, L. 1974. Chromatographic and biological aspects of DDT and its metabolites. Journal of Chromatography. 98: $177-251$.

Fishbein, L. 1976. Teratogenic, mutagenic, and carcinogenic effects of insecticides. In Insecticide Biochemistry and Physiology, ed. C.F. Wilkinson, pp. 555-603. New York: Plenum Press.

Focht, D.D. \& M. Alexander. 1971. Aerobic cometabolism of DDT analogues by Hydrogenomonas spp. Journal of Agricultural and Food Chemistry. 19(1): 20-22.

Forrester, D.J., Odell, D.K., Thompson, N.P. \& J.R. White. 1980. Morphometrics, parasites, and chlorinated hydrocarbon residues of pygmy killer whales from Florida. Journal of Mammalogy. 61(2): 356-360. 
Fournier, M., Bernier, J., Flipo, D. \& K. Krzystyniak. 1986. Evaluation of pesticide effects on humoral response to sheep erythrocytes and mouse hepatitis virus 3 by immunosorbent analysis. Pesticide Biochemistry and Physiology. 26: 353-364.

Francis, B.M. 1994. Toxic Substances in the Environment. New York: John Wiley.

Frank, R., Ronald, K. \& H.E. Braun. 1973. Organochlorine residues in harp seals (Pagophilus groenlandicus) caught in eastern Canadian waters. Journal of the Fisheries Research Board of Canada. 30(8): 1053-1063.

Freeman, H.C. \& G.B. Sangalang. 1977. A study of the effects of methyl mercury, cadmium, arsenic, selenium, and PCB (Aroclor 1254), on adrenal and testicular steroidogenises in vitro, by the grey seal Halichoerus grypus. Archives of Environmental Contamination and Toxicology. 5: 369-383.

Friend, M. \& D.O. Trainer. 1970. Polychlorinated biphenyl: interaction with duck hepatits virus. Science. 170: 1314-1316.

Fries, G.F. 1977. The kinetics of halogenated hydrocarbon retention and elimination in dairy cattle. In Fate of Pesticides in Large Animals, eds. G.W. Ivie \& H.W. Dorough, pp. 159-173. New York: Academic Press.

Fries, G.F., Marrow, Jr., G.S. \& C.H. Gordon. 1973. Long-term studies of residue retention and excretion by cows fed a polychlorinated biphenyl (Aroclor 1254). Journal of Agricultural and Food Chemistry. 21(1): 117-121.

Fry, D.M. \& C.K. Toone. 1981. DDT-induced feminization of gull embryos. Science. 213: 922-924. 
Gaskin, D.E. 1982. The Ecology of Whales and Dolphins. London: Heinemann.

Gaskin, D.E., Frank, R. \& M. Holdrinet. 1983. Polychlorinated biphenyls in harbor porpoises Phocoena (L.) from the Bay of Fundy, Canada and adjacent waters, with some information on chlordane and hexachlorobenzene levels. Archives of Environmental Contamination and Toxicology. 12: 211-219.

Gaskin, D.E., Frank, R., Holdrinet, M., Ishida, K., Walton, C.J. \& M. Smith. 1973. Mercury, DDT, and PCB in harbour seals (Phoca vitulina) from the Bay of Fundy and Gulf of Maine. Journal of the Fisheries Research Board of Canada. 30(3): 471-475.

Gaskin, D.E., Holdrinet, M. \& R. Frank. 1982. DDT residues in blubber of harbour porpoise, Phocoena (L.), from eastern Canadian waters during the five-year period 1969-1973. In Mammals in the Seas, pp. 135-143. FAO Fisheries Service No. 5, Vol. 4. New York: FAO.

Gaskin, D.E., Smith, G.J.D., Arnold, P.W., Louisy, M.V., Frank, R., Holdrinet, M. \& J.W. McWade. 1974. Mercury, DDT, dieldrin, and PCB in two species of Odontoceti (Cetacea) from St. Lucia, Lesser Antilles. Journal of the Fisheries Research Board of Canada. 31(7): 1235-1239.

George, C.J. \& W.J. George. 1994. Environmental health. In Basic Environmental Toxicology, eds. L.G. Cockerhom \& B.S. Shane, pp. 427-455. Boca Raton, Fl.: CRC Press.

Geraci, J.R. 1989. Clinical Investigation of the 1987-88 Mass Mortality of Bottlenose Dolphins Along the US Central and South Atlantic Coasts. Final Report, NMFS, Office of Naval Research.

Gibson, D.T. 1968. Microbial degradation of aromatic compounds. Science. 161: 1093-1097. 
Gilbert, F.F. 1969. Physiological effects of natural DDT residues and metabolites on ranch mink. Journal of Wildlife Management. 33(4): 933-943.

Gilmartin, W.C., DeLong, R.L., Smith, A.W., Sweeney, J.C., DeLappe, B.W., Risebrough, R.W., Griner, L.A., Dailey, M.D. \& D.B. Peakall. 1976. Premature parturition in the California sea lion. Journal of Wildlife Diseases. 12: 104-115.

Goldberg, E.D. 1991. Halogenated hydrocarbons: past, present and near-future problems. The Science of the Total Environment. 100: 17-28.

Granby, K. \& C. Kinze. 1991. Organochlorines in Danish and west Greenland harbour porpoises. Marine Pollution Bulletin. 22(9): 458-462.

Grant., D.L., Villeneuve, D.C., McCully, K.A. \& W.E.J. Phillips. 1971. Placental transfer of polychlorinated biphenyls in the rabbit. Environmental Physiology and Biochemistry. 1: 61-66.

Gulland, F.M.D., Trupkiewicz, J.G., Spraker, T., Lowenstine, L.J., Stein, J., Tilbury, K.L., Reichert, W.L. \& T. Hom. 1995. Metastatic carcinoma and exposure to chemical contaminants in California sea lions (Zalophus californianus) stranded along the central California coast. Abstract, Eleventh Biennial Conference on the Biology of Marine Mammals, Orlando, Fl.

Gunther, F.A., Westlake, W.E. \& P.S. Jaglan. 1968. Reported solubilities of 738 pesticide chemicals in water. Residue Reviews. 20: 1-148.

Guthrie, F.E. \& JJJ. Perry. 1980. Introduction to Environmental Toxicology. New York: Elsevier.

Guyton, A. 1986. Textbook of Medical Physiology. Philadelphia: W.B. Saunders. 
Hackwell, J.A. \& C. Self. 1978. Pesticide analysis-what has HPLC to offer. Proceedings of the Analytical Division of the Chemical Society. 15(11): 307-309.

Haegele, M.A. \& R.K. Tucker. 1974. Effects of 15 common environmental pollutants on eggshell thickness in mallards and coturnix. Bulletin of Environmental Contamination and Toxicology. 11(1): 98-102.

Haenni, E.O., Howard, J.W. \& Joe, Jr., F.L. 1962. Dimethyl sulfoxide: a superior analytical extraction solvent for polynuclear hydrocarbons and some highly chlorinated hydrocarbons. Journal of the Association Official Agricultural Chemists. 45: 67-70.

Hakansson, H., Manzoor, E. \& U. Ahlborg. 1992. Effects of technical PCB preparations and fractions thereof on vitamin A levels in the mink (Mustela vison). Ambio. 21(8): 588-590.

Haley, D. 1978. Steller's sea cow. In Marine Mammals, ed. D. Haley, pp. 236-241. Seattle: Pacific Search Press.

Hall, A.J., Law, R.J., Wells, D.E., Harwood, J., Ross, H.M., Kennedy, S., Allchin, C.R., Campbell, L.A. \& P.P. Pomeroy. 1992. Organochlorine levels in common seals (Phoca vitulina) which were victims and survivors of the 1988 phocine distemper epizootic. The Science of the Total Environment. 115: $145-162$.

Hall, E.R. 1981. The Mammals of North America, Vol. II. New York: John Wiley.

Haraguchi, K., Athanasiadou, M., Bergman, A., Hovander, L. \& S. Jensen. 1992. PCB and PCB methyl sulfones in selected groups of seals from Swedish waters. Ambio. 21(8): 546-549.

Harms. U., Drescher, H.E. \& E. Huschenbeth. 1978. Further data on heavy metals and organochlorines in marine mammals from German coastal waters. Meeresforsch. 26: 153-161. 
Hart, M.M., Whang-Peng, J., Sieber, S.M., Fabro, S. \& R.H. Adamson. Distribution and effects of DDT in the pregnant rabbit. Xenobiotica. 2(6): 56-74.

Harwood, J. \& P.J.H. Reijnders. 1988. Seals, sense and sensibility. New Scientist. 120(1634): 28-29.

Hayes, Jr., W.J. 1965. Review of the metabolism of chlorinated hydrocarbon insecticides, especially in mammals. Annual Review of Pharmacology. 5: 27-52.

Hayes, Jr., W.J. 1975. Toxicology of Pesticides. Baltimore: Williams and Wilkens.

Haymaker, W., Ginzter, A.M. \& R.L. Ferguson. 1946. The toxic effect of prolonged ingestion of DDT on dogs with special reference to lesions in the brain. American Journal of the Medical Sciences. 212: 423-439.

Helle, E., Olsson, M. \& S. Jensen. 1976. PCB levels correlated with pathological changes in seal uteri. Ambio. 5: 261-263.

Henny, C.J., Bean, J.R. \& R.W. Fyfe. 1976. Elevated heptachlor epoxide and DDE residues in a merlin that died after migrating. Canadian Field-Naturalist. 90(3): 361-363.

Heppleston, P.B. 1973. Organochlorines in British grey seals. Marine Pollution Bulletin. 4: 44-45.

Hickey, J.J., Keith, J.A. \& F.B. Coon. 1966. An exploration of pesticides in a Lake Michigan ecosystem. Journal of Applied Ecology, Supplement. 3: 141-154.

Hodgson, E. \& L. Tate. 1976. Cytochrome P-450 interactions. In Insecticide Biochemistry and Physiology, ed. C.F. Wilkinson, pp. 115-148. New York: Plenum Press.

Holan, G. 1971. Rational design of degradable insecticides. Nature. 232: 644-647. 
Holden, A.V. 1972. Monitoring organochlorine contamination of the marine environment by the analysis of residues in seals. In Marine Pollution and Sea Life, ed. M. Ruivo, pp. 266-272. West Byfleet, Eng.: Fishing News Books.

Holden, A.V. 1973. International cooperative study of organochlorine and mercury residues in wildlife, 1969-71. Pesticides Monitoring Journal. 7(1): 37-52.

Holden, A.V. 1975. Monitoring persistent organic pollutants. In Organochlorine Insecticides: Persistent Organic Pollutants, ed. F. Moriarty, pp. 1-27. London: Academic Press.

Holden, A.V. 1978. Pollutants and seals - a review. Mammal Review. 8: 53-66.

Holden, A.V. \& K. Marsden. 1967. Organochlorine pesticides in seals and porpoises. Nature. 216: 1274-1276.

Hom, W., Risebrough, R.W., Souter, A. \& D.R. Young. 1974. Deposition of DDE and polychlorinated biphenyls in dated sediments of the Santa Barbara Basin. Science. 184: 1197-1199.

Horgan, Jr., D.F. 1974. High speed liquid chromatography. In Analytical Methods for Pesticides and Plant Growth Regulators, vol. VII, eds. J. Sherma \& G. Zweig, pp. 89-115. New York: Academic Press.

Horwitz, W. 1980. Official Methods of Analysis of the Association of Official Analytical Chemists. Washington, DC: Association of Official Analytical Chemists (AOAC).

Hull, H.M. 1970. Leaf structure as related to absorption of pesticides and other compounds. Residue Reviews. 31: 1-150. 
Hunt, E.G. \& A.I. Bischoff. 1960. Inimical effects on wildlife of periodic DDD applications to Clear Lake. California Fish and Game. 46(1): 91-106.

Hurtig, H. 1972. Long-distance transport of pesticides. In Environmental Toxicology of Pesticides, ed. F. Matsumura, G. Boush, \& T. Misato, pp. 257-280. New York: Academic Press.

Hutzinger, O., Safe, S. \& V. Zitko. 1974. The Chemistry of PCB's. Cleveland: CRC Press.

Iwata, H., Tanabe, S., Sakai, N. \& R. Tatsukawa. 1993. Distribution of persistent organochlorines in the oceanic air and surface seawater and the role of ocean on their global transport and fate. Environmental Science and Technology. 27: 1080-1098.

Jager, K.W. 1970. Aldrin, Dieldrin, Endrin and Telodrin. Amsterdam: Elsevier.

Jansson, S., Jensen, S., Olsson, M., Renberg, L., Sundstrom, G. \& R. Vaz. 1975. Identification by GC-MS of phenolic metabolites of PCB and p,p-DDE isolated from Baltic guillemot and seal. Ambio. 4(2): 93-97.

Jeffries, D.J. 1975. The role of the thyroid in the production of sublethal effects by organochlorine insecticides and polychlorinated biphenyls. In Organochlorine Insecticides: Persistent Organic Pollutants, ed. F. Moriarty, pp. 132-230. London: Academic Press.

Jeffries, D.J. \& M.C. French. 1971. Hyper-and hypothyroidism in pigeons fed DDT: an explanation for the "thin eggshell" phenomenon. Environmental Pollution. 1(3): 235-242.

Jensen, S., Johnels, A.G., Olsson, M. \& G. Otterlind. 1969. DDT and PCB in marine animals from Swedish waters. Nature. 224: $247-250$. 
Johnson, G.A. \& S.M. Jalal. 1973. DDT-induced chromosomal damage in mice. Journal of Heredity. 64: 7-8.

Jones, D., Lavigne, D.M., Frank, R., Holdrinet, M. \& J.F. Uthe. 1976. Organochlorine and mercury residues in the harp seal (Pagophilus groenlandicus). The Science of the Total Environment. 5: 181-195.

Kaloyanova, F. \& M. El Batawi. 1991. Human Toxicology of Pesticides. Boca Raton, Fl.: CRC Press.

Kaminsky, L.S., Piper, L.J., McMartin, D.M. \& M.S. Fasco. 1978. Induction of hepatic microsomal cytochrome P-450 by mirex and kepone. Toxicology and Applied Pharmacology. 43: 327-338.

Kenaga, E.E. 1972. Factors related to bioconcentration of pesticides. In Environmental Toxicology of Pesticides, eds. F. Matsumura, G.M. Boush, \& T. Misato, pp. 193-228. New York: Academic Press.

Keil, J.E. \& L.E. Priester. 1969. DDT uptake and metabolism by a marine diatom. Bulletin of Environmental Contamination and Toxicology. 4: 169-173.

Keith, J.O. 1991. Historical perspectives. In Wildlife Toxicology by T. Peterle, pp. 1-21. New York: Van Nostrand Reinhold.

Kelly-Garvert, F. \& M.S. Legator. 1973. Cytogenic and mutagenic effects of DDT and DDE [1,1-dichloro-2,2-bis ( $\mathrm{p}$-chlorodiphenyl)ethylene] in a Chinese hamster cell line. Mutation Research. 17(2): 223-229.

Kemper, C., Gibbs, P., Obendorf, D., Marvanek, S. \& C. Lenghaus. 1994. A review of heavy metal and organochlorine levels in marine mammals in Australia. The Science of the Total Environment. 154: 129-139. 
Kendall, M.D., Safieh, B., Harwood, J. \& P.P. Pomeroy. 1992. Plasma thymulin concentrations, the thymus, and organochlorine contaminant levels in seals infected with phocine distemper virus. The Science of the Total Environment. 115: 133-144.

Kennedy, S., Hall, A.J., Law, R.J., Harwood, J., Ross, H.M. \& P.P. Pomeroy. 1988. Viral distemper now found in porpoises. Nature. 336: 21.

Kihlstrom, J.E., Olsson, M., Jensen, S., Johansson, A., Ahlbon, J. \& A. Bergman. 1992. Effects of PCB and different fractions of PCB on reproduction of the mink (Mustela vison). Ambio. 21(8): 563-569.

Kilgore, W. \& M. Li. 1976. Environmental toxicology. In Insecticide Biochemistry and Physiology, ed. C.F. Wilkinson, pp. 669-713. New York: Plenum Press.

Kinter, W.B., Merkins, L.S., Janicki, R.H. \& A.M. Guarino. 1972. Studies on the mechanism of toxicity of DDT and polychlorinated biphenyls (PCB's): disruption of osmoregulation in marine fish. Environmental Health Perspectives. 1: 169-173.

Kirchner, J.G. 1978. Thin-Layer Chromatography. New York: John Wiley.

Kleinow, K.M. \& M.S. Goodrich. 1994. Environmental aquatic toxicology. In Basic Environmental Toxicology, eds. L.G. Cockerhom \& B.S. Shane, pp. 353-384. Boca Raton, Fl.: CRC Press.

Kleivane, L., Skaare, J., Bjorge, A., de Ruiter, E. \& P.J.H. Reijnders. 1995. Organochlorine pesticide residue and PCB's in harbor porpoise (Phocoena phocoena) incidentally caught in Scandinavian waters. Environmental Pollution. 89(2): 137-146. 
Klinkenborg, V. 1995. A farming revolution: sustainable agriculture. National Geographic. 188(6); 61-88.

Koeman, J.H. \& H. van Genderen. 1966. Some preliminary notes on residues of chlorinated hydrocarbon insecticides in birds and mammals in the Netherlands. Journal of Applied Ecology, Supplement. 3: 99-106.

Koeman, J.H., Ten Noever de Brauw, M.C. \& R.H. de Vos. 1969. Chlorinated biphenyls in fish, mussels, and birds from the River Rhine and the Netherlands coastal area. Nature. 221: 1126-1128.

Koeman, J.H., Peeters, W.H.M., Smith, C.J., Tjioe, P.S. \& J.J.M. de Goeij. 1972. Persistent chemicals in marine mammals. TNO Nieuws. 27: 570-578.

Kolaja, G.J. \& D.E. Hinton. 1979. DDT-induced reduction in eggshell thickness, weight, and calcium is accompanied by calcium ATPase inhibition. In Animals as Monitors of Pollutants, pp. 309-318. Washington, DC: NAS.

Korschgen, L.J. 1970. Soil-food-chain-pesticide wildlife relationships in aldrin-treated fields. Journal of Wildlife Management. 34(1): 186-199.

Kuehl, D.W., Haebler, R. \& C. Potter. 1991. Chemical residues in dolphins from the U.S. Atlantic coast including Atlantic bottlenose obtained during the $1987 / 1988$ mass mortality. Chemosphere. 22(11): 1017-1084.

Kurtz, D.A. \& J.L. George. 1977. DDT metabolism in Pennsylvania white-tail deer. In Fate of Pesticides in Large Animals, eds. G.W. Ivie \& H.W. Dorough, pp. 193-215. New York: Academic Press.

Kurtz, D.A. \& K.C. Kim. 1976. Chlorinated hydrocarbon and PCB residues in tissues and lice of northern fur seals, 1972. Pesticides Monitoring Journal. 10(3): 79-83. 
Larsson, P. 1984. Uptake of sediment-released PCB's by the eel Anguilla anguilla in a static model system. Ecological Bulletin. 32: 62-67.

Law, R.L., Allchin, C.R. \& J. Harwood. 1989. Concentrations of organochlorine compounds in the blubber of seals from eastern and north-eastern England, 1988. Marine Pollution Bulletin. 20(3): 110-115.

Lawrence, J.F. \& D. Turton. 1978. High-performance liquid chromatographic data for 166 pesticides. Journal of Chromatography. 159: 207-226.

Le Boeuf, B.J. \& Bonnell, M.L. 1971. DDT in California sea lions. Nature. 234: 108-110.

Lewis, C.T. 1965. Influence of cuticle structure and hypodermal cells on DDT absorption by Phormia terraenovae R-D. Journal of Insect Physiology. 11: 683-694.

Lichtenstein, E.P. \& K.R. Schulz. 1960. Epoxidation of aldrin and heptachlor in soils as influenced by autoclaving, moisture, and soil types. Journal of Economic Entomology. 53(2): 192-197.

Lichtenstein, E.P. \& K.R. Schulz. 1961. Effect of soil cultivation, soil surface and water on the persistence of insecticide residues in soils. Journal of Economic Entomology. 54(3): 517-522.

Lichtenstein, E.P., Fuhremann, T.W., Scopes, N.E.A. \& R.F. Skrentny. 1967a. Translocation of insecticides from soils into pea plants. Journal of Agricultural and Food Chemistry. 15(5): 864-869.

Lichtenstein, E.P., Fuhremann, T.W., Schulz, K.R., \& R.F. Skrentny. $1967 \mathrm{~b}$. Effects of detergents and inorganic salts in water on the persistence and movement of insecticides in soils. Journal of Economic Entomology. 60(6): 1714-1722. 
Lieberg-Clark, P., Bacon, C.E., Burns, S.A., Jarman, W.M. \& B.J. Le Boeuf. 1995. DDT in California sea-lions: A follow-up study after twenty years. Marine Pollution Bulletin. 30(11): 744-745.

Loganathan, B.G. \& K. Kannan. 1991. Time perspectives of organochlorine contamination in the global environment. Marine Pollution Bulletin. 22(12): 582-584.

Loganathan, B.G. \& K. Kannan. 1994. Global organochlorine contamination trends: an overview. Ambio. 23(3): 187-191.

Loganathan, B.G., Tanabe, S., Tanaka, H., Watanabe, S., Miyazaki, N., Amano, M., \& R. Tatsukawa. 1990. Comparison of organochlorine residue levels in the striped dolphin from western North Pacific, 1978-79 and 1986. Marine Pollution Bulletin. 21(9): 435-439.

Luckas, B., Vetter, W., Fischer, P., Heidemann, G. \& J. Plotz. 1990. Characteristic chlorinated hydrocarbon patterns in the blubber of seals from different marine regions. Chemosphere. 21(1-2): 13-19.

Lund, B.O. 1994. In vitro adrenal bioactivation and effects on steroid metabolism of DDT, PCB's and their metabolites in the gray seal (Halichoerus grypus). Environmental Toxicology and Chemistry. 13(6): 911-917.

Luoma, J.R. 1995. Havoc in the hormones. Audubon. 97(4): 60-67.

Lustick, S., Voss, T. \& T. Peterle. 1973. Effects of DDT on steroid metabolism and energetics in bobwhite quail (Colinus virginianus). In First National Bobwhite Quail Symposium, eds. J.A. Morrison \& J.C. Lewis, pp. 213-233. Stillwater, Ok.: Oklahoma University Press.

Macek, K.J. \& W.A. McAllister. 1970. Insecticide susceptibility of some common fish family representatives. Transactions of the American Fisheries Society. 99(1): 20-27. 
MacGregor, J.S. 1974. Changes in the amount and proportions of DDT and its metabolites, DDE and DDD, in the marine environment off southern California. Fisheries Bulletin. 72: 275-293.

MacNeil, J.D., Safe, S. \& O Hutzinger. 1976. The ultraviolet absorption spectra of some chlorinated biphenyls. Bulletin of Environmental Contamination and Toxicology. 15: 66-77.

Madej, A., Forsberg, M. \& L.E. Edqvist. 1992. Urinary excretion of cortisol and oestrone sulfate in pregnant mink fed PCB and fractions of PCB. Ambio. 21(8): 582-585.

Martin, H. 1956. The chemistry of insecticides. Annual Review of Entomology. 1: 149-166.

Martineau, D., Beland, P., Desjardins, C. \& A. Lagace. 1987. Levels of organochlorine chemicals in tissues of beluga whales (Delphinapterus leucas) from the St. Lawrence estuary, Quebec, Canada. Archives of Environmental Contamination and Toxicology. 16: 137-147.

Martineau, D., De Guise, S., Fournier, M., Shugart, L., Girard, C., Lagace, A. \& P. Beland. 1994. Pathology and toxicology of beluga whales from the St. Lawrence River estuary, Quebec, Canada: past, present, and future.. The Science of the Total Environment. 154: 201-215.

Martineau, D., Lagace, A., Beland, P., Higgins, R., Armstrong, D. \& L.R. Shugart. 1988. Pathology of stranded beluga whales (Delphinapterus leucas) from the St. Lawrence estuary, Quebec, Canada. Journal of Comparative Pathology. 98: 287-311.

Mate, B.R. 1978. California sea lion. In Marine Mammals, ed. D. Haley, pp. 172-177. Seattle: Pacific Search Press.

Matsumura, F. 1975. Toxicology of Insecticides. New York: Plenum Press. 
Matsumura, F. 1982. Degradation of pesticides in the environment by microorganisms and sunlight. In Biodegradation of Pesticides, F. Matsumura \& C.R. Krishna Murti, pp. 67-90. New York: Plenum Press.

Matsumura, F. \& H.J. Benezet. 1973. Studies on the bioaccumulation and microbial degradation of 2,3,7,8tetrachlorodibenzo-p-dioxin. Environmental Health Perspectives. 5: 253-258.

Matsumura, F. \& G.M. Boush. 1968. Degradation of insecticides by a soil fungus Trichoderma viride. Journal of Economic Entomology. 61(3): 610-612.

Matsumura, F., Patil,K.C. \& G.M. Boush. 1971. DDT metabolism by microorganisms from Lake Michigan. Nature. 230: 325-326.

McEwen, F.L. \& G.R. Stephenson. 1979. The Use and Significance of Pesticides in the Environment. New York: John Wiley.

McKinney, J., Chae, K., Gupta, B.N., Moore, J.A. \& J.A. Goldstein. 1976. Toxicological assessment of hexachlorobiphenyl isomers and 2,3,7,8-tetrachlorodibenzofuran in chicks. I. relationship of chemical parameters. Toxicology and Applied Pharmacology. 36: 65-80.

McLaughlin, Jr., J., Marliac, J.P., Verrett, M.J., Mutchler, M.K. \& O.G. Fitzhugh. 1963.The injection of chemicals into the yolk sac of fertile eggs prior to incubation as a toxicity test. Toxicology and Applied Pharmacology. 5(6); 760-771.

McMahon, B.M. \& N.F. Hardin, eds. 1994. Pesticide Analytical Manual, vol. 1. Rockville, Md.: USDHHS-FDA.

Melnikov, V.N. 1971. Chemistry of Pesticides. New York: Springer-Verlag.

Mendoza, C.E. 1981. Thin-layer chromatography. In Pesticide Analysis, ed. K.G. Das, pp. 1-43. New York: Marcel Dekker. 
Miles, J.R.W. 1972. Conversion of DDT and its metabolites to dichlorobenzophenones for analysis in the presence of polychlorinated biphenyls. Journal of the Association of Official Analytical Chemists. 55(5): 1039-1041.

Miles, J.R.W. 1980. Adsorption of insecticide residues - importance in environmental sampling and analysis. In Hydrocarbons and Halogenated Hydrocarbons in the Aquatic Environment, eds. B.F. Afghan \& D. Mackay, pp. 81-90. New York: Plenum Press.

Misra, , U.K., Nag, D., Misra, N.K., Mehra, M.K. \& P.K. Rag. 1985. Some observations on the macula of pesticide workers. Human Toxicology. 4: 135-138.

Miyamoto, J., Takimoto, Y. \& K. Mihara. 1979. Metabolism of organophosphorous insecticides in aquatic organisms, with special emphasis on fenitrothion. In Pesticide and Xenobiotic Metabolism in Aquatic Organisms, eds. M. Kahn, J. Leck \& J. Menn, pp. 3-21. Washington, DC: American Chemical Society.

Moriarty, F. 1972. The effects of pesticides on wildlife: exposure and residues. The Science of the Total Environment. 1: 267-288.

Moriarty, F. 1983. Ecotoxicology. London: Academic Press.

Muir, D.C.G., Ford, C.A., Grift, N.P. \& R.E.A. Stewart. 1992. Organochlorine contaminants in narwhal (Monodon monoceros) from the Canadian Arctic. Environmental Pollution. 75: 307-316.

Muir, D.C.G., Ford, C.A., Rosenberg, B., Simon, M., Norstrom, R.J. \& K. Langelier. 1991. PCB's and other organochlorine contaminants in marine mammals from the Strait of Georgia. Abstract, SETAC Twelfth Annual Meeting, Washington, DC. 
Muir, D.C.G., Ford, C.A. \& R.E.A. Stewart. 1990. Organochlorine contaminants in belugas, Delphinapterus leucas, from Canadian waters. Canadian Bulletin of Fisheries and Aquatic Sciences. 224: 165-190.

Muir, D.C.G., Norstrom, R.J. \& M. Simon. 1988a. Organochlorine contaminants in Arctic marine food chains: accumulation of specific polychlorinated biphenyls and chlordane-related compounds. Environmental Science and Technology. 22: 1071-1079.

Muir, D.C.G., Wagemann, R., Grift, N.P., Norstrom, R.J., Simon, M. \& J. Lien. 1988b. Organochlorine chemical and heavy metal contaminants in white-beaked dolphins (Lagenorhynchus albirostris) and pilot whales (Globicephala melaena) from the coast of Newfoundland, Canada. Archives of Environmental Contamination and Toxicology. 17: 613-629.

Mulhern, B.M., Cromartie, E., Reichel, W.L. \& A.A. Belisle. 1971. Semiquantitative determination of polychlorinated biphenyls in tissue samples by thin layer chromatography. Journal of the Association of Official Analytical Chemists. 54(3): 548-550.

Narahashi, T. 1987. Neuronal target sites of insecticides. In Sites of Action for Neurotoxic Pesticides, eds. R.M. Hollingworth \& M.B. Green, pp. 226-250. Washington, DC: American Chemical Society.

Neilson, A.H. 1994. Organic Chemicals in the Aquatic Environment. Boca Raton, Fl.: Lewis Publishers.

Nicklin, C. 1995. The future. In Whales, Dolphins and Porpoises, ed. M.C. Christian, pp. 205-225. Washington, DC: National Geographic Society.

O'Brien, R.D. 1967. Insecticides: Action and Metabolism. New York: Academic Press. 
Oehme, M. 1991. Further evidence for long-range air transport of polychlorinated aromates and pesticides: North America and Eurasia to the Arctic. Ambio. 20(7): 293-297.

Oehme, M., Furst, P., Kruger, C., Meemken, H.A. \& W. Groebel. 1988. Presence of polychlorinated dibenzo-p-dioxins, dibenzofurans and pesticides in Arctic seal from Spitzbergen. Chemosphere. 17(7): 1291-1300.

Ofstad, E.B. \& K. Martinsen. 1983. Persistent organochlorine compounds in seals from Norwegian coastal waters. Ambio. 12(5): 262-264.

Ohlendorf, H.M. \& W.J. Fleming. 1988. Birds and environmental contaminants in San Francisco and Chesapeake Bays. Marine Pollution Bulletin. 19(9): 487-495.

Ohlendorf, H.M., Schaffner, F.C., Custer, T.W. \& C.J. Stafford. 1985. Reproduction and organochlorine contaminants in terns at San Diego Bay. Colonial Waterbirds. 8(1): 42-53.

Olsson, M., Karlsson, B. \& E Ahnland. Diseases and environmental contaminants in seals from the Baltic and the Swedish west coast. The Science of the Total Environment. 154: 217-227.

Orberg, J. 1977. Placental and mammary transfer of two PCB's $\left(2,4,5-\right.$ TCB $^{\prime}$ and $\left.2,2^{\prime}, 4,4^{\prime}, 5,5^{\prime}-\mathrm{HCB}\right)$ and their effect on reproductive capacity in mice. Ambio. 6(5): 278-280.

O'Shea, T.J. \& R.L. Brownell, Jr. 1994. Organochlorine and metal contaminants in baleen whales: a review and evaluation of conservation implications. The Science of the Total Environment. 154: 179-200.

O'Shea, T.J., Brownell, Jr., R.L., Clark, Jr., D.R., Walker, W.A., Gay, M.L. \& T.G. Lamont. 1980. Organochlorine pollutants in small cetaceans from the Pacific and South Atlantic Oceans, November 1968 - June 1976. Pesticides Monitoring Journal. 14(2): 35-46. 
Osselton, M.D. \& R.D. Snelling. 1986. Chromatographic identification of pesticides. Journal of Chromatography. 368: 265-271.

Osterhaus, A.D.M.E. \& E.J. Vedder. 1988. Identification of virus causing recent seal deaths. Nature. 335: 20.

Osterhaus, A.D.M.E. \& E.J.Vedder. 1989. No simplification in the etiology of recent seal deaths. Ambio. 18(5): 297-298.

Otterlind, G. 1976. The harbour porpoise (Phocoena phocoena) endangered in Swedish waters. International Council for the Exploration of the Sea (ICES) C.M. 1976/N:16.

Parke, D.V. 1968. The Biochemistry of Foreign Compounds. Oxford: Pergamon Press.

Parr, J.A. 1987. Pesticides. Washington, DC: American Chemical Society Information Pamphlet, November.

Parsons, A.H. \& T.J. Peterle. 1977. DDE and avian eggshell thinning: ultrastructural evidence of decreased parathyroid activity. Poultry Science. 56(5): 1745.

Patin, S.A. 1982. Pollution and the Biological Resources of the Oceans. London: Butterworth Scientific.

Peakall, D.B. 1970. Pesticides and the reproduction of birds. Scientific American. 222(4): 72-78.

Peakall, D.B. \& J.L. Lincer. 1970. Polychlorinated biphenyls: another long-life, widespread chemical in the environment. Bioscience. 20(17): 958-964.

Peakall, D.B. \& M.L. Peakall. 1973. Effect of a polychlorinated biphenyl on the reproduction of artificially and naturally incubated dove eggs. Journal of Applied Ecology. 10(3): 863-868. 
Peterle, T.J. 1991. Wildlife Toxicology. New York: Van Nostrand Reinhold.

Peterman, P.H., Delfino, J.J., Dube, D.J., Gibson, T.A. \& F.J. Priznar. 1980. Chloro-organic compounds in the lower Fox River, Wisconsin. In Hydrocarbons and Halogenated Hydrocarbons in the Aquatic Environment, eds. B.K. Afghan \& D. Mackay, pp. 145-160.

Petrick, G., Schulz, D.E. \& J.C. Duinker. 1988. Clean-up of environmental samples by high-performance liquid chromatography for analysis of organochlorine compounds by gas chromatography with electron-capture detection. Journal of Chromatography. 435: 241-248.

Phillips, D.J.H. 1994. Ecotoxicological impacts of PCB's. Marine Pollution Bulletin. 28(4): 192-193.

Poland, A. \& J.C. Knutson. 1982. 2,3,7,8-tetrachlorodibenzop-dioxin and related halogenated aromatic hydrocarbons: examination of the mechanism of toxicity. Annual Review of Pharmacology and Toxicology. 22: 517-554.

Poland, A. \& E. Glover. 1977. Chlorinated biphenyl induction of aryl hydrocarbon hydroxylase activity: a study of the structure activity relationship. Molecular Pharmacology. 13: $924-938$.

Popov, T.A. \& B.J. Blaauboer. 1991. Biotransformation of pesticides: the role of the mixed function oxidase system in pesticide toxicity. In Toxicology of Pesticides in Animals, ed. T.S.S. Dikshith, pp. 41-65. Boca Raton, Fl.: CRC Press.

Postel, S. 1988. Controlling toxic chemicals. In State of the World 1988 , ed. L. Starke, pp. 118-136. New York: W.W. Norton.

Preston, M.R. 1992. The interchange of pollutants between the atmosphere and oceans. Marine Pollution Bulletin. 24(10): 477-483. 
Prestt, l. 1965. An enquiry into the recent breeding status of some of the smaller birds of prey and crows in Britain. Bird Study. 12: 196-221.

Prestt. I., Jeffries, J. \& N.W. Moore. 1970. Polychlorinated biphenyls in wild birds in Britain and their avian toxicity. Environmental Pollution. 1(1): 3-26.

Pryde. L.T. 1973. Pesticides, Food, and Drugs. Menlo Park, Ca.: Cummings Publishing.

Quintanilla-Lopez, J.E., Lebron-Aguilar, R. \& L.M. Polo-Diez. 1992. Comparative study of clean-up and fractionation methods for the determination of organochlorine pesticides in lipids by gas chromatography. Journal of Chromatography. 591: 303-311.

Quraishi, M.S. \& Z.T. Poonawalla. 1969. Radioautographic study of the diffusion of topically applied DDT-C 14 into the housefly and its distribution in internal organs. Journal of Economic Entomology. 62(5): 988-994.

Ramade, F. 1987. Ecotoxicology. Chichester, Eng.: John Wiley.

Ratcliffe, D.A. 1963. The status of the Peregrine in Great Britain. Bird Study. 10: 56-90.

Ratcliffe, D.A. 1967. Decrease in eggshell weight in certain birds of prey. Nature. 215: 208-210.

Ratcliffe, D.A. 1970. Changes attributable to pesticides in egg breakage frequency and eggshell thickness in some British birds. Journal of Applied Ecology. 7(1): 67-115.

Rattner, B.A., Fleming, W.J. \& H.C. Murray. 1983. Osmoregulatory function in ducks following ingestion of the organophosphorus insecticide fenthion. Pesticide Biochemistry and Physiology. 20(2): 246-255. 
Raven, P.H., Berg, L.R. \& G.B. Johnson. 1995. Environment, 1995 Version. Fort Worth, Tx.: Saunders .

Reeves, R.R., Stewart, B.S. \& S. Leatherwood. 1992. The Sierra Club Handbook of Seals and Sirenians. San Francisco: Sierra Club Books.

Reichel, W.L. \& C.E. Addy. 1968. A survey of chlorinated pesticide residues in Black Duck eggs. Bulletin of Environmental Contamination and Toxicology. 3: 174-179.

Reijnders, P.J.H. 1980. Organochlorine and heavy metal residues in harbour seals from the Wadden Sea and their possible effects on reproduction. Netherlands Journal of Sea Research. 14: 30-65.

Reijnders, P.J.H. 1982. On the ecology of the harbour seal Phoca vitulina in the Wadden Sea: population dynamics, residue levels, and management. Veterinary Quarterly. 4: 36-42.

Reijnders, P.J.H. 1986. Reproductive failure in common seals feeding on fish from polluted coastal waters. Nature. 324: 456-457.

Reijnders, P.J.H. 1994. Toxicokinetics of chlorobiphenyls and associated physiological responses in marine mammals, with particular reference to their potential for ecotoxicological risk assessment. The Science of the Total Environment. 154: 229-236.

Reynolds, L.M. 1969. Polychlorobiphenyls (PCB's) and their interference with pesticide residue analysis. Bulletin of Environmental Contamination and Toxicology. 4: 128-143.

Rice, D.W. 1977. A List of the Marine Mammals of the World, NOAA Technical Report NMFS SSRF-711. Washington, DC: NTIS. 
Risebrough, R.W. 1969. Chlorinated hydrocarbons in marine ecosystems. In Chemical Fallout: Current Research on Persistent Pesticides, ed. M. Miller, pp. 5-23. Springfield, Il.: Charles C. Thomas.

Risebrough, R.W. 1978. Pollutants in Marine Mammals: $\underline{A}$ Literature Review and Recommendations for Research. NTIS PB-290728. Washington, DC: Marine Mammal Commission.

Risebrough, R.W., Huggett, R.J., Griffin, J.J. \& E.D. Goldberg. 1968 Pesticides: transatlantic movements in the northeast trades. Science. 159: 1233-1235.

Risebrough, R.W., Walker II, W., Schmidt, T.T., de Lappe, B.W. \& C.W. Connors. 1976. Transfer of chlorinated biphenyls to Antarctica. Nature. 264: 738-739.

Robinson, J. 1969. Organochlorine insecticides and bird populations in Britain. In Chemical Fallout: Current Research on Persistent Pesticides, ed. M. Miller, pp. 113-173. Springfield, Il.: Charles C. Thomas.

Robinson, J., Richardson, A., Crabtree, A.N., Coulson, J.C. \& G.R. Potts. 1967. Organochlorine residues in marine organisms. Nature. 214: 1307-1311.

Roos, A., Blomkvist, G., Olsson, M., Jensen, S., Bergman, A. \& T. Harkonen. 1992. Sample selection and preparation procedures for analyses of metals and organohalogen compounds in Swedish seals. Ambio. 21(8): 525-528.

Rosen, J.D. \& D.J. Sutherland. 1967. The nature and toxicity of the photoconversion products of aldrin. Bulletin of Environmental Contamination and Toxicology. 2: 1-9.

Rosen, J.D., Sutherland, D.J. \& G.R. Lipton. 1966. The photochemical isomerization of dieldrin and endrin and effects on toxicity. Bulletin of Environmental Contamination and Toxicology. 1: 133-140. 
Rosewell, K.T. \& B.E. Baker. 1979. A method for confirming organochlorine pesticide residues in wildlife. Bulletin of Environmental Contamination and Toxicology. 21: 470-477.

Rosewell, K.T., Muir, D.C.G. \& B.E. Baker. 1979. Organochlorine residues in harp seal (Pagophilus groenlandicus) tissues, Gulf of St. Lawrence, 1971, 1973. Pesticides Monitoring Journal. 12(4): 189-192.

Rudd, R. 1964. Pesticides and the Living Landscape. Madison, Wi.: University of Wisconsin Press.

Safe, S. 1984. Polychlorinated biphenyls (PCB's) and polybrominated biphenyls (PBB's): biochemistry, toxicology, and mechanism of action. Critical Reviews in Toxicology. 13: 319-393.

Safe, S. \& O. Hutzinger. 1971. Polychlorinated biphenyls: photolysis of 2,4,6,2',4',6'-hexachlorobiphenyl. Nature. 232: 641-642.

Sanyal, S., Agarwal, N. \& D. Subrahmanyan. 1986. Effect of acute sublethal and chronic administration of DDT (chlrophenotane) on brain-lipid metabolism of Rhesus monkeys. Toxicology Letters. 34: 47-59.

Sawyer, T \& S. Safe. In vitro AHH induction by polychlorinated biphenyl and dibenzofuran mixtures: additive effects. Chemosphere. 14: 79-84.

Sax, I.N. 1955. Dangerous Properties of Industrial Materials. New York: Reinhold.

Schafer, H.A., Gossett, R.W., Ward, C.F. \& A.M. Westcott. 1984. Chlorinated Hydrocarbons in Marine Mammals, Biennial Report, 1983-1984. Long Beach, Ca.: Southern California Coastal Water Research Project. 
Schantz, M.M., Koster, B.J., Wise, S.A. \& P.R. Becker. 1993. Determination of PCB's and chlorinated hydrocarbons in marine mammal tissues. The Science of the Total Environment. 139/140: 323-345.

Schmidt, K. 1994. Can superfund get on track? National Wildlife. 32(3): 10-17.

Seiber, J.N. 1974. Reversed-phase liquid chromatography of some pesticides and related compounds: solubility-retention relationships. Journal of Chromatography. 94: 151-157.

Seidl, G. \& K. Ballschmiter. 1979. Quantitation of polychlorinated biphenyl (PCB)-residues after hydrodechlorination to biphenyl using liquid chromatography with UV-detection. Fresenius Zeitschrift fur Analytische Chemie. 296: 281-284.

Shaw, S.B. 1971. Chlorinated hydrocarbon pesticides in California sea otters and harbor seals. California Fish and Game. 57(4): 290-294.

Sherma, J. 1974. Thin-layer chromatography: recent advances. In Analytical Methods for Pesticides and Plant Growth Regulators, vol. VII, eds. J. Sherma \& G. Zweig, pp. 3-88. New York: Academic Press.

Sherma, J. 1981. Manual of Analytical Quality Control for Pesticides and Related Compounds in Human and Environmental Samples. EPA 600/2-81-059. Research Triangle Park, NC.: USEPA.

Sherma, J. \& G. Zweig. 1983. Pesticides. Analytical Chemistry. 55: 57R-70R.

Sherma, J. \& G. Zweig. 1985. Pesticides. Analytical Chemistry. 57: 1R-15R. 
Shimabukura, R., Lamoureux, G. \& D. Frear.1982. Pesticide metabolism in plants: reactions and mechanisms. In Biodegradation of Pesticides, ed. F. Matsumura \& C.R. Krishna Murti, pp. 21-66. New York: Plenum Press.

Skaare, J.U., Markussen, N.H., Norheim, G., Haugen, S. \& G. Holt. 1990. Levels of polychlorinated biphenyls, organochlorine pesticides, mercury, cadmium, copper, selenium, arsenic, and zinc in the harbour seal, Phoca vitulina, in Norwegian waters. Environmental Pollution. 66: 309-324.

Slijper, E.J. 1977. Whales. Ithaca, NY.: Cornell University Press.

Smith, G.J. \& R.I. Hall. 1994. Wildlife toxicology. In Basic Environmental Toxicology, eds. L.G. Cockerhom \& B.S. Shane, pp. 409-424. Boca Raton, Fl.: CRC Press.

Snyder, D. \& R. Reinert. 1971. Rapid separation of polychlorinated biphenyls from DDT and its analogues. Bulletin of Environmental Contamination and Toxicology. 6: 385-390.

Spencer, W.F., Farmer, W.J. \& M.M. Cliath. 1973. Pesticide volatilization. Residue Reviews. 49: 1-47.

Stickel, L.F. 1968. Organochlorine Pesticides in the Environment. Special Scientific Report on Wildlife, No. 119. Washington, DC: USFWS.

Stoker, H.S. \& S.L. Seager. 1977. Organic chemical pollution: petroleum, pesticides, and detergents. In Environmental Chemistry, ed. J. O'M. Bockris, pp. 401-427. New York: Plenum Press.

Stone, W.B., Kiviat, E. \& S.A. Butkas. 1980. Toxicants in snapping turtles. New York Fish and Game Journal. 27(1): 39-50. 
Strachan, W.M.J., Huneault, H., Schertzer, W.M. \& F.C. Elder. 1980. Organochlorines in precipitation in the Great Lakes region. In Hydrocarbons and Halogenated Hydrocarbons in the Aquatic Environment, eds. B.F. Afghan \& D. Mackay, pp. 387-396. New York: Plenum Press.

Street, J.C. \& R.P. Sharma. 1975. Alteration of induced cellular and humoral immune responses by pesticides and chemicals of environmental concern: quantitative studies of immunosuppression by DDT, Aroclor 1254, carbaryl, carbofuran, and methylparathion. Toxicology and Applied Pharmacology. 32(3): 587-602.

Subramanian, A.N., Tanabe, S, \& R. Tatsukawa. 1988. Use of organochlorines as chemical tracers in determining some reproductive parameters in Dalli-type Dall's porpoise Phocoenoides dalli. Marine Environmental Research. 25: 161-174.

Subramanian, A.N., Tanabe, S., Tatsukawa, R., Saito, R. \& N. Miyazaki. 1987. Reduction in the testerone levels by PCB's and DDE in Dall's porpoises of the northwestern North Pacific. Marine Pollution Bulletin. 18: 643-646.

Sumich, J.L. 1996. An Introduction to the Biology of Marine Life. Dubuque, la.: W.C. Brown.

Sundstrom, G., Hutzinger, O., Safe, S. \& N. Platonow. 1977. The metabolism of p,p-DDT and p,p-DDE in the pig. In Fate of Pesticides in Large Animals, eds. G.W. Ivie \& H.W. Dorough, pp. 175-182.

Swain, W.R. 1980. An ecosystem approach to the toxicology of residue forming xenobiotic organic substances in the Great Lakes. In Working Papers for the Committee on Revised Methods for Ecotoxicology, pp. 193-257. Washington, DC: NAS. 
Szelewski, M.J., Hill, D.R., Spiegel, S.J. \& E.C. Tifft, Jr. 1979. Loss of polychlorinated biphenyl homologues during chromium trioxide extraction of fish tissue. Analytical Chemistry. 51(14): 2405-2407.

Tanabe, S. 1985. Distribution, behaviour and fate of PCB's in the marine environment. Journal of the Oceanographical Society of Japan. 41: 358-370.

Tanabe, S. 1988. PCB problems in the future: foresight from current knowledge. Environmental Pollution. 50: 5-28.

Tanabe, S. 1991. Fate of toxic chemicals in the tropics. Marine Pollution Bulletin. 22: 259-260.

Tanabe, S., Iwata, H. \& R. Tatsukawa. 1994. Global contamination by persistent organochlorines and their ecotoxicological impact on marine mammals. The Science of the Total Environment. 154: 163-177.

Tanabe, S., Mori, T., Tatsukawa, R. \& N. Miyasaki. 1983. Global pollution of marine mammals by PCB's, DDT's and HCH's (BHC's). Chemosphere. 12(9/10): 1269-1275.

Tanabe, S., Tatsukawa, R., Maruyama, K. \& N. Miyazaki. 1982. Transplacental transfer of PCB's and chlorinated hydrocarbon pesticides from the pregnant striped dolphin (Stenella coeruleoalba) to her fetus. Agricultural and Biological Chemistry. 46: 1249-1254.

Tanabe, S., Tanaka, H. \& R. Tatsukawa. 1984. Polychlorobiphenyls, tDDT, and hexachlorocyclohexane isomers in the western North Pacific ecosystem. Archives of Environmental Contamination and Toxicology. 13: 731-738.

Tanabe, S., Watanabe, S., Kan, H. \& R. Tatsukawa. 1988. Capacity and mode of PCB metabolism in small cetaceans. Marine Mammal Science. 4(2): 103-124. 
Tarrant, K.R. \& J.O'G. Tatton. 1968. Organochlorine pesticides in rainwater in the British Isles. Nature. 219: 725-727.

Taruski, A.G., Olney, C.E. \& H.E. Winn. 1975. Chlorinated hydrocarbons in cetaceans. Journal of the Fisheries Research Board of Canada. 32(11): 2205-2209.

Tas, A.C. \& R.J.C. Kleipool. 1972. Characterization of the components of technically polychlorinated biphenyl mixtures-II. Bulletin of Environmental Contamination and Toxicology. 8: 32-37.

Tatsukawa, R. \& S. Tanabe. 1990. Fate and bioaccumulation of persistent organochlorine compounds in the marine environment. In Oceanic Processes in Marine Pollution, vol. 6, eds. D.J. Baumgartner \& I.W. Duedall, pp. 39-52. Melbourne, Fl.: Krieger Publishing.

Tatton, J. O'G. \& J.H. Ruzicka. 1967. Organochlorine pesticides in Antarctica. Nature. 215: 346-348.

Tomatis, L., Turusov, V., Day, N. \& R.T. Charles. 1972. Effect of long-term exposure to DDT on CF-1 mice. International Journal of Cancer. 10(3): 489-506.

Tucker, R.K. \& D.G. Crabtree. 1970. Handbook of Toxicity of Pesticides to Wildlife. Resource Publication No. 84. Denver: Bureau of Sports Fisheries and Wildlife.

Van Velzen, A.C., Stiles, W.B. \& L.F. Stickel. 1972. Lethal mobilization of DDT by cowbirds. Journal of Wildlife Management. 36(3): 733-739.

Vershueren, K. 1983. Handbook of Environmental Data on Organic Chemicals. New York: Van Nostrand Reinhold.

von den Bosch, R. 1969. The toxicity problem - comments by an applied insect ecologist. In Chemical Fallout: Current Research on Persistent Pesticides, eds. M.W. Miller \& G.G. Berg, pp. 97-112. Springfield, 1l.: Charles C. Thomas. 
Vos, J.G. \& M.I. Luster. 1989. Immune Alterations. In Halogenated Biphenyls, Terphenyls, Naphthalenes, Dibenzodioxins and Related Products, eds. R.D. Kimbrough \& A.A. Jensen, pp. 295-322. Amsterdam: Elsevier.

Wagemann, R. \& D.C.G. Muir. 1984. Concentrations of heavy metals and organochlorines in marine mammals of northern waters: overview and evaluation. Canadian Technical Report of Fisheries and Aquatic Sciences, No. 1279.

Waggoner III, J.P. \& M.G. Zeeman. 1975. DDT: short-term effects on osmoregulation in black surfperch (Embiotoca jacksoni). Bulletin of Environmental Contamination and Toxicology. 13: 297-300.

Walker, C.H. 1983. Pesticides and birds - mechanisms of selective toxicity. Agriculture Ecosystems and Environment. 9(2): 211-226.

Walker, A.I.T., Thorpe, E. \& D.E. Stevenson. 1972. Toxicology of dieldrin (HEOD) I. long-term oral toxicity studies in mice. Food and cosmetics Toxicology. 11(3): 415-432.

Wallace, M.E. 1971. An unprecedented number of mutants in a colony of wild mice. Environmental Pollution. 1(3): 175-184.

Wania, F. \& D. Mackay. 1993. Global fractionation and cold condensation of low volatility organochlorine compounds in polar regions. Ambio. 22(1): 10-18.

Ware, D. \& R. Addison. 1973. PCB residues in plankton from the Gulf of St. Lawrence. Nature. 246: 519-521.

Wassermann, M., Wassermann, D., Gershon, Z. and L. Zellermayer. 1969. Effects of organochlorine insecticides on body defense systems. Annals of the New York Academy of Sciences. 160: 393-401. 
Wassermann, M., Wassermann, D., Zellermayer, L. \& M. Gon. 1967. Storage of DDT in the people of Israel. Pesticides Monitoring Journal. 1(2): 15-20.

Weber, P. 1992. A place for pesticides? World Watch. 5(3): 18-25.

West, T.F. \& G.A. Campbell. 1950. DDT and Newer Persistent Pesticides. London: Chapman \& Hall.

Wheeler, W.B. \& N.P. Thompson. 1981. Analysis of chlorinated hydrocarbons. In Analysis of Pesticide Residues, ed. H.A. Moye, pp. 199-222. New York: John Wiley.

Williams, J., Higginson, J.J. \& J.D. Rohrbough. 1975. Sea and Air: the Marine Environment. Annapolis: Naval Institute Press.

Wills, J.H. 1969. Effects of chlorinated hydrocarbons on smaller animals as guides in the design of experiments with human volunteers. In Chemical Fallout: Current Research on Persistent Pesticides, eds. M.W. Miller \& G.G. Berg, pp. 461-467. Springfield, Il.: Charles C. Thomas.

Willmott, F.W. \& R.J. Dolphin. 1974. A novel combination of liquid chromatography and electron capture detection in the analysis of pesticides. Journal of Chromatographic Science. 12: 695-700.

Wilson, D.E. \& D.M. Reeder. 1993. Mammal Species of the World. Washington, DC: Smithsonian Institution Press.

Wiltrout, R.W., Ercegovich, C.D. \& W.S. Ceglowski. 1978. Humoral immunity in mice following oral administration of selected pesticides. Bulletin of Environmental Contamination and Toxicology. 20: 423-431.

Winn, H.E. \& G.P. Scott. 1978. A Model for Stock Structuring of Humpback Whales (Megaptera novaeangliae) in the western North Atlantic. Draft Record to International Whaling Commission. 
Wolff, W.J. 1982. The status of marine mammals in the Wadden Sea area. In Marine Mammals of the Wadden Sea, eds. P.J.H. Reijnders \& W.J. Wolff, pp. 7-14. Final Report of the Wadden Sea Working Group, No. 7.

Wolman, A.A. \& A.J. Wilson, Jr. 1970. Occurrence of pesticides in whales. Pesticides Monitoring Journal. 4(1); 8-10.

Woodwell, G.M., Craig, P.P. \& H.A. Johnson. 1971. DDT in the biosphere: where does it go? Science. 174: 1101-1107.

Yarbrough, J.D., Chambers, J.E. \& K.M. Robinson. 1982. Alteration in liver structure and function resulting from chronic insecticide exposure. In Effects of Chronic Exposure to Insecticides on Animal Systems, eds. J.E. Chambers \& J.D. Yarbrough, pp. 25-38. New York: Raven Press.

Young, S.J.V. \& J.A. Burke. 1972. Micro scale alkali treatment for use in pesticide residue confirmation and sample cleanup. Bulletin of Environmental Contamination and Toxicology. 7: 160-167.

Zubay, G. 1986. Biochemistry. Menlo Park, Ca.: Benjamin-Cummings. 